\title{
IMPROVING STUDENT INTERNSHIP \\ THROUGH COLLABORATIVE CURRICULUM DESIGN \\ IN GHANAIAN POLYTECHNICS
}

Edward Akomaning 


\title{
DOCTORAL COMMITTEE
}

\begin{tabular}{|c|c|}
\hline Chairman & Prof. Dr. E. R. Seydel - University of Twente \\
\hline Promotor & Prof. Dr. J. M. Pieters $=$ University of Twente \\
\hline Assistant promotor & Dr. J. M. Voogt $=$ University of Twente \\
\hline \multirow[t]{6}{*}{ Members } & Prof. Dr. J. J. H. van den Akker $=$ University of Twente \\
\hline & Prof. Dr. J. W. M. Kessels — University of Twente \\
\hline & Dr. C. van Vilsteren $=$ University of Twente \\
\hline & Prof. Dr. M. Volman = University of Amsterdam \\
\hline & Prof. Dr. E. de Bruijn $\approx$ University of Utrecht \\
\hline & Dr. C. Terlouw $₫$ Saxion University of Applied Sciences \\
\hline
\end{tabular}

\begin{abstract}
Akomaning, E.
Improving student internship through collaborative curriculum design in Ghanaian polytechnics
\end{abstract}

Thesis University of Twente, Enschede.

ISBN 978-90-365-3318-8

DOI 10.3990/1.9789036533188

Cover design: Simon Seidu

Layout: Sandra Schele

Printer: Ipskamp Drukkers B.V. Enschede

(C) Copyright, 2012, E. Akomaning 


\title{
IMPROVING STUDENT INTERNSHIP THROUGH COLLABORATIVE CURRICULUM DESIGN IN GHANAIAN POLYTECHNICS
}

\author{
DISSERTATION \\ to obtain \\ the degree of doctor at the University of Twente, \\ on the authority of the rector magnificus, \\ prof. dr. H. Brinksma, \\ on account of the decision of the graduation committee \\ to be publicly defended \\ on $25^{\text {th }}$ of January 2012 at 16.45
}

by

Edward Akomaning

born on the $2^{\text {nd }}$ of February 1960

in Sekondi, Ghana 
Promotor

Assistant promotor
Prof. Dr. J. M. Pieters

Dr. J. M. Voogt

This dissertation has been approved by the promotor and assistant promotor. 


\section{TABLE OF CONTENTS}

LIST OF FIGURES AND TABLES $\quad$ v

ACKNOWLEDGEMENTS vii

1. INTRODUCTION 1

1.1 Problem definition 1

1.1.1 Polytechnic Education in Ghana 1

1.1.2 The need for capacity building in Ghana's polytechnic education 2

1.1.3 The state of internships in Ghana 3

1.2 Research context 3

1.2.1 Prospects of the hospitality industry in Ghana 3

1.2.2 Hotel Catering and Institutional Management 4

1.3 Theoretical framework 5

1.3.1 Collaborative curriculum design $\quad 5$

1.3.2 Workplace learning theory 8

$\begin{array}{ll}1.4 \text { Research model } & 10\end{array}$

1.5 Research approach $\quad 12$

1.5.1 Research questions and relevance 12

$\begin{array}{ll}1.6 \text { Structure of the dissertation } & 14\end{array}$

2. INTERNSHIP IN VOCATIONAL EDUCATION AND TRAINING: STAKEHOLDERS' PERCEPTIONS OF ITS ORGANISATION 15

2.1 Introduction $\quad 15$

2.2 Conceptual framework $\quad 17$

2.3 VET and higher education in Ghana 20

2.4 Context of the study 21

2.5 Methods $\quad 22$

2.5.1 Respondents 22

$\begin{array}{lll}2.5 .2 & \text { Instrumentation } & 23\end{array}$ 
2.6 Results 23

2.6.1 Perspectives of stakeholders: collaboration 23

2.6.2 Perspectives of stakeholders: placements 24

2.6.3 Perspectives of stakeholders: duration 25

2.6.4 Perspectives of stakeholders: assessment 26

2.6.5 Perspectives of stakeholders: support 30

2.6.6 Perspectives of stakeholders: time extension 31

2.6.7 Perspectives of stakeholders: teacher involvement 31

2.6.8 Perspectives of stakeholders: closer collaboration 32

2.7 Conclusion and discussion 33

\section{TOWARDS A RENEWED STUDENT INTERNSHIP IN GHANA'S} POLYTECHNICS: THROUGH COLLABORATIVE CURRICULUM DESIGN IN DESIGN TEAMS

3.1 Introduction 35

3.2 Theoretical underpinnings 37

3.2.1 Design teams and collaborative curriculum design 37

3.2.2 Prerequisites for implementation of renewed internship 38

3.3 Context of the study 40

3.4 Focus of the study 41

3.5 Intervention: CCD in design teams 41

3.6 Methods 43

3.6.1 Design of the study 43

3.6.2 Participants 43

3.6.3 Research instruments 43

3.6.4 Data analysis 46

3.7 Results 47

3.7.1 Perceptions about CCD in design teams 47

3.7.2 Perspectives of stakeholders about renewed student internship $\quad 48$

3.7.3 Students' assessment of industry contribution to renewed internship 50

3.7.4 Teachers' assessment of the renewed internship 50

3.7.5 Assessment of job performance by stakeholders 52

3.7.6 Improved internship practices $\quad 52$

3.7.7 Competencies of students 53

3.7.8 Description of competencies acquired 56

3.8 Conclusion and discussion $\quad 57$ 


\section{TOWARDS A RENEWED STUDENT INTERNSHIP THROUGH}

COLLABORATIVE DESIGN OF CURRICULUM MATERIALS

4.1 Introduction 59

4.2 Theoretical underpinnings 61

4.2.1 Ensuring quality curriculum materials during collaborative design

4.2.2 Practicality of the curriculum materials in renewed internship

4.2.3 Effects and assessment of curriculum materials on students' competencies

4.2.4 Institutional support for renewed internship 63

4.2.5 Resolution of implementation challenges 64

4.3 Context of the study 64

4.4 Intervention 65

4.5 Research questions 66

4.6 Methods 67

$\begin{array}{lll}\text { 4.6.1 Participants } & 67\end{array}$

4.6.2 Research instrumentation $\quad 67$

$\begin{array}{ll}\text { 4.6.3 Data analysis } & 70\end{array}$

4.7 Results $\quad 70$

4.7.1 How do design teams ensure quality of curriculum materials?

$\begin{array}{lll}\text { 4.7.2 } & \text { Practical use of student internship guide } & 72\end{array}$

$\begin{array}{ll}\text { 4.7.3 Competencies of students } & 75\end{array}$

$\begin{array}{lll}\text { 4.7.4 Institutional support } & 79\end{array}$

4.7.5 Resolution of implementation challenges 81

4.8 Conclusion and discussion 83

5. TOWARDS SUSTAINABLE STUDENT INTERNSHIP PRACTICES IN GHANAIAN POLYTECHNICS: THE IMPACT OF COLLABORATIVE CURRICULUM DESIGN

5.1 Introduction $\quad 85$

5.2 Theoretical underpinnings 86

5.2.1 Curriculum contributing to improved student internship practices 86

5.2.2 The potential of collaborative curriculum design for curriculum improvement $\quad 88$ 
$\begin{array}{ll}5.3 \text { Purpose of the study } & 90\end{array}$

5.4 Context of the study 90

5.5 Methods 92

5.5.1 Design of the study 92

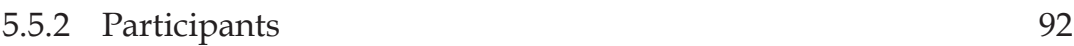

$\begin{array}{lll}5.5 .3 & \text { Research instruments } & 93\end{array}$

5.5.4 Data analysis $\quad 95$

5.6 Results 96

5.6.1 Teacher perspective on influence of curriculum materials 101

5.6.2 Industry perspective on influence of curriculum materials 105

5.6.3 Student perspective on influence of curriculum materials 106

5.6.4 Teacher perspective on improved practices 108

5.6.5 Industry perspective on improved practices 110

5.6.6 Student perspective on improved practices 111

5.6.7 Management representative perspective on improved

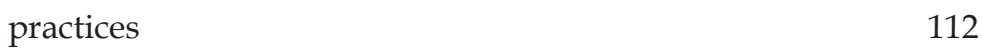

$\begin{array}{lll}\text { 5.6.8 Teacher opinions } & 113\end{array}$

5.6.9 Management representative opinions $\quad 116$

$\begin{array}{ll}5.7 \text { Conclusion and discussion } & 117\end{array}$

6. REFLECTIONS 121

6.1 Recapping research phases and results $\quad 121$

6.2 Reflecting on the research approach 126

$\begin{array}{ll}6.3 \text { Outcomes and reflections } & 127\end{array}$

$\begin{array}{ll}6.4 \text { Recommendations } & 131\end{array}$

$\begin{array}{lr}\text { REFERENCES } & 137\end{array}$

$\begin{array}{lr}\text { ENGLISH SUMMARY } & 147\end{array}$

$\begin{array}{ll}\text { DUTCH SUMMARY } & 155\end{array}$

$\begin{array}{ll}\text { APPENDICES } & 165\end{array}$ 


\section{LIST OF FIGURES AND TABLES}

\section{FIGURES}

1.1 Map of Ghana 4

1.2 The model connecting the stages of the research to CCD 11

6.1 The model connecting the stages of the research to CCD 123

\section{TABLES}

2.1 Overview of the constructs and example questions/statements 23

2.2 Views of stakeholders on involvement of internship 24

2.3 Views of stakeholders on assessment of internship 26

2.4 Summary of perceptions of stakeholders regarding internship 27

2.5 Views of stakeholders on implementation of internship 28

2.6 Students' views on challenges faced during internship 28

2.7 Summary of implementation challenges 29

2.8 Stakeholders' suggestions for improvement on implementation of internship

2.9 Summary suggestions for improvement on implementation of internship

3.1 Overview of the intervention 42

3.2 Overview of research instruments and constructs addressed 44

3.3 Teacher perceptions about CCD in design teams before and after internship

$\begin{array}{lll}3.4 & \text { Views of stakeholders regarding renewed student internship } & 49 \\ 3.5 & \text { Students' }\end{array}$

3.6 Assessment of 2009 internship by teachers 51

3.7 Assessment of job performance 52

3.8 Assessment of curriculum materials for internship 53

3.9 Competencies of students in Food Production after intervention 54

3.10 Competencies of students in Food and Beverage after intervention $\quad 54$

3.11 Competencies of students in Front Office Operation after intervention 
3.12 Competencies of students in Accommodation Operation after intervention

4.1 Overview of intervention

4.2 Overview of instrument administration

4.3 Collaborative efforts of teachers in design teams

4.4 Perception of student guide for internship

4.5 Competencies of students in food production

4.6 Competencies of students in food and beverage service

4.7 Competencies of students in front office operation

4.8 Competencies of students in accommodation operation 78

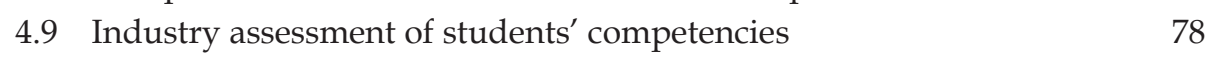

$\begin{array}{ll}4.10 \text { Assessment of students } & 79\end{array}$

4.11 Assessment of polytechnic support $\quad 80$

4.12 Teachers' evaluation of student internship $\quad 81$

4.13 Views of stakeholders on supervision in student internship $\quad 82$

4.14 Students' assessment of industry contribution to internship $\quad 82$

5.1 Overview of research instruments and constructs addressed 94

5.2 Reasons for engaging in CCD as reported by teachers 96

5.3 Teachers' views on the influence of curriculum materials for student internship

5.4 Influence of curriculum materials on student internship - students' perspectives

5.5 Addressing internship challenges through curriculum materials teachers' perspectives

5.6 Addressing internship challenges through curriculum materials students' perspectives

5.7 Opinions of teachers towards CCD in design teams 


\section{ACKNOWLEDGEMENTS}

First and foremost my sincerest thanks go to the Almighty God for His strength, protection, favour and wisdom that sustained me through the entire research project period at the University of Twente. I cannot suppress my feelings but to honour his name.

Moreover, the realisation of this dissertation would not have been written without the encouragement and support of many individuals and organisations. I wish to express my deep appreciation to Prof. Dr. Jules M. Pieters (promotor) and Associate Prof. Joke Voogt (assistant promotor) for their patience, constructive criticisms, encouragement and fruitful support given me throughout the entire academic exercise. I would forever remain grateful for your invaluable contributions. I have actually learnt a lot from you and I will endeavour to exhibit same in my academic and professional career.

It is equally important to take cognisance of all the colleagues in the Department of Curriculum Design and Educational Innovation and in the International Students Office at the University of Twente for your professional, academic and social support. Ms. Sandra Schele, I am very thankful to you for making this book presentable and also for other administrative updates and information.

I am also very much indebted to Drs. Esther Hartog, Project coordinator of NPT (The Netherlands Programme for the Institutional Strengthening of Postsecondary Education and Training Capacity), Ms. Eek Dia and other CIS (Centre for International Cooperation) staff at Vrije Universiteit as well as the Dutch Government. Their timely financial disbursement to me made my stay in the Netherlands comfortable and enjoyable. NUFFIC, without whose support this may not have come about, I am deeply thankful. 
Further appreciation goes to my various respondents at Ho Polytechnic, Kumasi Polytechnic, Tamale Polytechnic and Takoradi Polytechnic, selected organisations in Ho, Kumasi, Tamale and Takoradi for their cooperation during data collection exercise in Ghana. Their input to the research work was of immense help.

I am also very grateful to all the staff of IEPA (Institute for Educational Planning and Administration), University of Cape Coast, Ghana. In this regard, Dr. George T. Oduro (Director, IEPA, Ghana), Dr. Albert Dare and Dr. Yaw Ankomah (IEPA, Ghana) whose contribution has made me come this far. I wish them well in all their endeavours.

The last but not the least compliment goes to all my family members in Ghana. Their prayer support and words of encouragement propelled me through the academic programme in the Netherlands. Mrs. Esther Laurinda Akomaning God richly blesses you for your preponderant support. Your good deeds will forever be remembered and rewarded in the womb of time.

Edward Akomaning 


\title{
CHAPTER 1 Introduction
}

\begin{abstract}
The first chapter presents an overview of the thesis. The chapter starts with a description of the problem. This is followed by a section where the specific context for the study is described. The theoretical framework guiding this study is presented in the subsequent section, followed by a description of the research model, the research questions and the rationale for the design-based research approach employed for the research project. Finally, the structure of the dissertation is provided.
\end{abstract}

\subsection{PROBLEM DEFINITION}

\subsubsection{Polytechnic education in Ghana}

Polytechnic education in Ghana began in technical and vocational institutes. In 1963, the three technical institutes in Accra, Takoradi and Kumasi were redesignated as polytechnics without legal backing (Effah, 2005). Neither facilities nor staff were upgraded to meet the new status of the polytechnics. Regardless of the elevation, they continued to operate essentially as non-tertiary, second cycle institutions, which offered mostly advanced craft courses and a few technician programmes. The Tamale and Ho Technical Institutes were elevated to polytechnic status in 1984 and 1986 respectively by the Ghana Education Service (GES). Cape Coast Polytechnic was opened in 1986 but it did not gain tertiary status until 1993. Sunyani and Koforidua Polytechnics were elevated to tertiary status in 1997. Later the Wa and Bolgatanga Polytechnics gained their status by political pronouncement.

The polytechnic Law, PNDCL 321, was enacted in 1993 which brought legal status to the polytechnics in the country. In order to ensure the proper coordination in the polytechnics and other tertiary institutions, the National 
Council for Tertiary Education (NCTE), the National Accreditation Board (NAB) and National Board for Professional and Technician Examinations (NABPTEX) were jointly set up for tertiary policy formulation and quality control (Girdwood, 1999). The standard set by NAB has been used for assessing the readiness of polytechnics to offer degree programmes.

Among the key objectives of upgrading the polytechnics was to improve the quality of teaching, to increase output particularly in technical and vocational level training, to improve cost-effectiveness, and to increase access to tertiary level education (Effah, 2001). The outputs from the polytechnics are expected to align with efficient and effective manpower demand in both the public and private sectors. Polytechnics education in Ghana emphasises diversity, vocational training and promotion of community learning (Akyeampong, 2010). The polytechnic curriculum is career-oriented and more practical in content than programmes offered in the university. Polytechnics in Ghana offer Higher National Diploma (HND) and non-HND programmes in three or four main schools: School of Engineering, School of Applied Science, School of Applied Arts, and School of Business and Management Studies.

The stakeholders involved in the design of the curriculum for the polytechnics at the national level are NABPTEX, representatives of polytechnics, industry, and professional bodies of the respective courses or programmes. NAB gives the final approval for polytechnics to adopt and implement the curriculum. The individual polytechnics are therefore not completely in control of the designed curriculum. But, the individual polytechnics have room for local adaptation.

\subsubsection{The need for capacity building in Ghana's polytechnic education}

By their establishment, the polytechnics as tertiary educational institutions aim to produce skilled and professional middle level management personnel to feed the various sectors of the economy of Ghana (Effah, 2005). To fulfil the polytechnics' mandate NABPTEX was set up in 1994 to coordinate the activities of the polytechnics regarding examinations, evaluation, assessment and curriculum development among others (Effah, 2001). The other places where practical experiences can be obtained are the industry and other relevant organisations in the country. To facilitate the relationship between the polytechnics and the industry on a number of issues, including student internship, industrial liaison units are established in each polytechnic (Gervedink Nijhuis, Bakah, \& Akomaning, 2009). 
In spite of these measures in place, Ghanaian Polytechnics are confronted with major obstacles. These obstacles could be linked to an episodic relationship between the polytechnics and industries (Gervedink Nijhuis et al., 2009), the haphazard nature of organising student internship (Effah, 2005), irregular revision of curricula (Effah, 2001), and supply-driven curricula instead of demand-driven (Akyeampong, 2010). Consequently, almost two decades from the time of the upgrading of the polytechnics to tertiary status, many polytechnic graduates cannot find appropriate jobs in industry, let alone establish their own businesses after graduation (Akyeampong, 2010; JICA Report, 2001). Although no tracer study has been carried out after the study by JICA, the high level of polytechnic graduates unemployed still persist. According to the JICA report the estimated percentage of unemployed polytechnic graduates was 30\% and the reason assigned was inadequate acquisition of employable skills. There is a growing public concern about the quality of polytechnic graduates.

\subsubsection{The state of internships in Ghana}

A main problem in the polytechnic system is its inability to facilitate effective internships for students. The polytechnics lack well written curriculum materials as well as coherence in curriculum for student internship. Effah (2005) describes the internship situation as unsystematic and unstructured partly because there is no clear curriculum for students, industry personnel and teachers to follow during internship.

The purpose of the present research is to contribute to an improved curriculum for student internship through the involvement of major stakeholders (teachers, industry and students) in the collaborative design of curriculum materials for student internship.

\subsection{RESEARCH CONTEXT}

\subsubsection{Prospects of the hospitality industry in Ghana}

Tourism, of which hospitality industry is a principal element, is becoming increasingly recognised as a valuable component of foreign exchange earner in Ghana (Figure 1.1 shows the major cities and towns with tourist attractions). In recent times the sector has grown steadily and it is perceived by the government as 
a sector which can generate employment, foreign exchange and wealth creation. Since the early 1980s tourism has become a sector within the economy that has gained special attention because it is the third largest foreign exchange earner, behind cocoa and gold In Ghana, the tourism industry is growing at the rate of 3.5 percent per annum. Its international receipts stood at US\$248.80m in 1996 (Ghana Tourist Board, 2005) and over the years has made giant strides which have enabled it to record immense revenue of US\$1.2billion in 2008. It is anticipated that tourism will become the first foreign exchange in Ghana by 2015. The expansion of the tourism sector could be due to the growing tourist trade and the opportunities offered by prudent macroeconomic policies. The result is the rapid growth in the activities in the hospitality industry (Ghana Tourist Board, 2009).

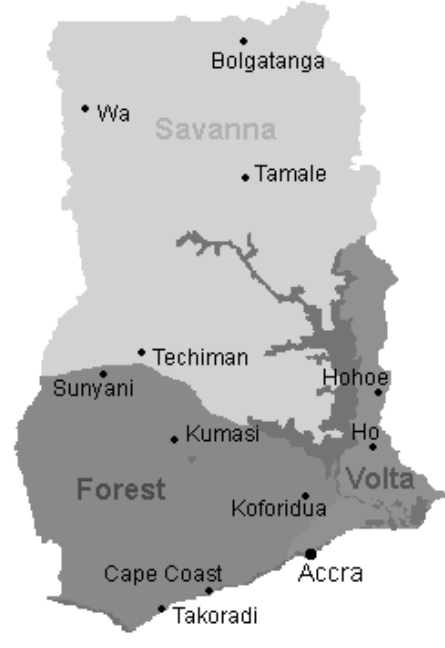

Source: http://www.google.co.uk

Figure 1.1 Map of Ghana
However, it has been observed that the country's hospitality industry lacks quality standards. The industry is in dire need of capacity development, with just under 15 percent of its workforce being trained countrywide (Acquah, 2009). Given the labourintensive nature of the hospitality industry, it is pertinent that human resource issues need to be addressed, as it will give hotels competitive advantage to encourage tourists to stay. The ability of Ghana's tourism sector achieving its goal by 2015 depends largely on the quality and competence of the human resource in the tourism sector, since it forms a key part in the delivery of the tourism products (Adjei \& Gyamfi, 2005). The worth of a nation is, in the main, contingent on the knowledge and skills of its citizens. It is therefore important to look at the polytechnic education in Ghana whose primary responsibility is to ensure human resource development.

\subsubsection{Hotel Catering and Institutional Management}

The context of this study is the Department of Hotel Catering and Institutional Management (HCIM) which is responsible for training students to assume managerial or supervisory roles in the hospitality industry in Ghana and beyond. The HCIM programme is a three-year tertiary programme which commenced in 
1993. Entrants into the programme are predominantly those who have successfully completed the Home Economics programme at the senior secondary school. Successful students graduate with the award of the HND certificate in hospitality management. Teaching and learning in the HCIM programme is supposed to be a blend of theoretical and practical lessons. In order to fulfil this mandate, internship programmes are organised for students where they apply to industries of their choice. Internship programmes are carried out in two sessions throughout the three-year programme. Each session spans a period of three months at the end of every academic year. So, in all students are supposed to make at least six months throughout the entire study period of three years. These internship periods are supposed to be supervised by both polytechnic educators and industry representatives. In order to facilitate the internship programmes, each polytechnic has the Industrial Liaison Unit, whose primary responsibility is to ensure that students have places to carry out internship.

\subsection{THEORETICAL FRAMEWORK}

\subsubsection{Collaborative curriculum design}

Levels of curriculum and its design

Curriculum as a course or 'plan for learning' (Taba, 1962) can be defined on different levels. Van den Akker (2003) delineates four levels: the macro level (system, society, national); the meso level (school, institution, programme); the micro level (classroom) and the nano level (individual, personal). In this research the curriculum being developed refers to a plan for student internship, which is considered the curriculum at meso level. Designing curricula, whether collaboratively or individually, presupposes a number of activities that generally take the form of analysis, design and development, implementation, and evaluation. As Van den Akker (2003) stipulates curriculum development: "...usually a long and cyclic process with many stakeholders and participants in which motives and needs for changing the curriculum are formulated; ideas are specified in programs and materials; and efforts are made to realize the intended changes in practice" (p. 2).

\section{Curriculum quality}

The quality of educational programmes in terms of their influence is, according to Kessels and Plomp (1999), to a large extent, determined by "consistency" of the curriculum. Kessels and Plomp (1999) distinguish between internal and external 
consistency. The logic sequence between the various components of the curriculum is defined as internal consistency. Internal consistency is reached through a "systematic approach" (Kessels \& Plomp, 1999). It implies the systematic design sequence of analysis, design, development, implementation and evaluation, comparable to the description of curriculum development by Van den Akker (2003). One aspect of internal consistency is to eliminate duplication or overlap of topics (Denton, Kleist, \& Surendra, 2005).

External consistency, on the other hand, refers to the coherence of perceptions of stakeholders on what the problem is for which an intervention is needed and how it should be solved. External consistency is reached through a "relational approach", corresponding to the communicative paradigm (Kessels \& Plomp, 1999). It implies the involvement of stakeholders in the design and development process, thereby revealing their perceptions on the main goals of the process and on how they should be achieved. Curriculum work is multifaceted hence the role or input of identifiable stakeholders in the design process should be given the utmost consideration. By so doing the divergent needs may be catered for and thereby promote the relevance to its subsequent users. As teachers are the main stakeholders, active involvement of teachers in curriculum design might essentially contribute to the external consistency.

\section{Stakeholders in curriculum design}

Marsh and Willis (2003) identify several stakeholders in the entire process of planning and developing the curriculum. The stakeholders range from educational officials, students, parents, members of the community and teachers. Within vocational education the teacher, student and employer are usually seen as key stakeholders in the process of planning and developing the curriculum (Hughes, 2009), in order to ensure that the collaboration between the educational institutions and industries is fostered with the ultimate aim of enriching students with employable skills.

\section{Teachers and curriculum enactment}

It is important to note that teachers are the persons who enact the curriculum; therefore, their professional role is to close the gaps between the planned curriculum and the curriculum actually experienced by their students (Van den Akker, 2005). They are the educational practitioners who live closest to the underlying tensions involved in curriculum work and who have the most at stake 
in understanding what curriculum development actually entails and how it influences them and the students in their classrooms (Marsh \& Willis, 2003). Moreover, involving teachers in the design of curriculum materials is considered useful in minimizing gaps between reform intentions and curriculum development and enactment (Westbroek et al., submitted). Research has shown that teachers' active involvement in the (re-)design of the curriculum results in curriculum materials that are both valid and feasible (Ben-Peretz, 1990; Clandinin \& Connelly, 1992; Penuel et al., 2007).

\section{Collaborative curriculum design and design teams}

This research seeks to design curriculum materials for student internship through collaborative curriculum design in design teams having received input from other key stakeholders (students and industry personnel). Collaborative curriculum design (CCD) as bottom-up approach is gradually advancing in education as a means to create teacher ownership during curriculum innovation (Borko, 2004; Johnson, 1993; Skilbeck, 1998; Villegas-Reimers, 2003), because in this approach to curriculum development the needs of the stakeholders involved in the design process are identified and understood, and their interest taken care of (Waddoups, Wentworth, \& Earle, 2004).

Design team refers to a cooperative or collaborative group working together to produce a unit of instruction or creating a product (Waddoups et al., 2004) which is implemented and evaluated (Handelzalts, 2009) in an educational institution programme. It implies that in the process of designing members (teachers) investigate challenges in their current instructional practice, how the product (re-) designed is implemented and evaluated. Collaboration in design teams, according to Handelzalts (2009) and Simmie (2007) contributes to enhanced teacher knowledge, skills and practices as well as sustainable curriculum implementation.

Research results indicate that through the sense of security that comes from design teams and support from colleagues, there is a greater willingness to experiment, try new things and be more apt to consider continual development in curriculum reform (Hargreaves, 2003). Participation in self-managed design teams, where members have the authority to make decisions and take actions to advance goals determined by the team, may intensify members' commitment to the team and to foster collaboration among team members (Muthusamy et al., 2005; Waddoups et al., 2004). Teachers in teams learn to use conflict and 
differences as being productive (Grossman, Wineburg, \& Woolworth, 2001). Teacher collaboration in design teams, according to Little (1990) and Riordan (2001) denote joint work, shared responsibility and the existence of high levels of trust, respect and mutuality. By collaborating, professionals pool their knowledge and can together create new knowledge.

Collaborative curriculum design in design teams allows teachers to carry out activities that lead to improvement in student learning (Havnes, 2009). Moreover, teacher professional development through increasing levels of participation within a design team are the key to how learning occurs in both students and team members (Blackwell, 2003). CCD in design teams is used during this research to prepare curriculum materials for student internship programme for hospitality management students.

The composition of design teams and their ability to elicit suggestions from other stakeholders in the design of curriculum materials for student internship cannot be overemphasized if quality work is to be ensured (cf. Kessels \& Plomp, 1999). In an effective collaborative design team, there should be the feeling that each other's contribution is required in order to ensure success in their work and new perspectives that colleagues bring on board are not disdained but respected (cf. Hargreaves, 2003; Little, 1990). The collaboration of teachers in teams increases the chance that the curriculum materials designed will become relevant (Plomp, 2009) for student internship.

Collaboration in curriculum design can potentially lead to several possible learning gains for teachers: e. g. content knowledge in a target domain (Fernandez, 2005; Kolodner et al., 2003; Rock \& Wilson, 2005; Voogt et al., 2011)); pedagogical and didactical knowledge and skills (Guskey, 2000) and general process and collaboration skills (Guskey, 2000; Kolodner, et al., 2003). However, for this research, pedagogical and didactical knowledge do not apply because the curriculum materials were used in the context of workplace learning in the industry during student internship.

\subsubsection{Workplace learning theory}

\section{Workplace learning}

The concept of workplace learning fits in recent developments of the learning sciences, where it is argued that learning to be effective, should be situated in 
meaningful contexts (Brown, Collins, \& Duguid, 1989; Lave \& Wenger, 1991; Resnick, 1987). In the 90s workplace learning has gone from being largely unnoticed to attracting unprecedented interest (Hager, 1998). One aspect of this expanded attention is a concern to ensure that formal workplace training is effective (Beck, 1994; Billett \& Rose, 1996; Sangster, Maclaran, \& Marshall, 2000). These researchers attribute early thinking about work-based learning to Pedler (1974), who observed that effective learning places the student at the centre of the learning experience. In addition, Sadler-Smith, Down, and Lean (2000) suggest that workplace learning can be enhanced through the effective use of more flexible learning methods - providing learners with increased choice, convenience, and personalisation to suit the learner where the mentors (e.g., workplace supervisors) serve as guide (Rothman, 2007; Wale, 2001). Illeries (2003) points out that the interest in vocational education and training has moved in the direction of workplace or internship learning activities in industry where human competence is becoming an increasingly decisive resource and parameter of competition.

The constructivists hold that learners construct knowledge from the circumstances in which they experience that knowledge (von Glasersfeld, 1987); they view learners' construction as an ongoing interpretive process that is reinforced by past and continuing experiences. Individuals make sense of knowledge in an interpretative and constructive way rather than internalising externally derived knowledge. Accordingly, as Rogoff (1995) argues, the appropriation of knowledge is not just the internalisation of externally derived stimuli; rather, it is the individual's construction of those stimuli. In this context, communication is viewed as a dynamic, two-way process in which meanings emerge in the space between the learner and the more expert other (Pea, 1993). Pea proposes that meaning negotiation and appropriation are integral to this process: Initial interpretative construction of knowledge is idiosyncratic, and it is through social mediation that the construction becomes more congruent and communicable. To promote meaning negotiation with respect to hidden knowledge in the workplace, activities that encourage continual participation and interaction are required (Billett, 1994). Billett and Rose (1996) contend that where learning requires conceptual change, strategies are needed to make sense of new conceptualisations.

\section{Conceptualisation of student internship practices}

Internship is considered as an opportunity to integrate career related experiences into an education programme by participating in planned and supervised work (Bakar, Harun, Yusof, \& Tahir, 2011). It is a temporary position with an emphasis 
on workplace learning, usually for a fixed period of time before graduation. According to Billett (2001) such an experience, learning through participating in work, can be understood in terms of how the workplace supports or inhibits individuals' engagement in work activities and access to both the direct and indirect guidance. Hence internships need to be conceptualised more clearly as authentic workplace learning environments (Blokhuis \& Nijhof, 2008) through which industry's contributions can be best organised to assist the learning required of the intern (Billett, 2006). Without the identification, conceptualisation and acknowledgement of an internship curriculum, internships will remain misunderstood and de-legitimised.

Billett (2006) argues that there is a critical need for internship curriculum practices because of the acknowledgement of the crucial role that internships play in individuals' initial learning and further development of vocational knowledge and skills throughout their working lives. Hasbullah and Sulaiman (2002) assert that students' competencies improve remarkably through the use of curriculum materials for student internship in their industrial experience. The researchers conclude that students are prepared to enter into the world of work with confidence and ready to cooperate with employers and other employees having accomplished a guided internship. Therefore, the use of curriculum materials specifying what to be learnt and who is responsible for what could create a better platform for internship to be better organised (Ko, 2008).

To sum up, the prerequisites to quality internship programme are premised on availability of a working document (curriculum) which spells out the roles of learners and mentors. The former (learners) should be guided but not controlled, and there should be effective communication between the learners and their mentors so as to unearth hidden knowledge in the workplace. Moreover, the workplace should endeavour to assist the learner by creating an authentic learning environment for the learners to explore their learning potentials so as to prepare learners to enter the labour market with knowledge and skills needed to be functional.

\subsection{RESEARCH MODEL}

Figure 1.2 displays the research model indicating how collaborative curriculum design (CCD) is connected to the various components that determine the design 
of curriculum materials for internship practices. These components are organised in such a way that they together structure the subsequent stages of the research project. The research model outlines the problem statement formulated based on the context which stimulates or serves as driver for the adoption of CCD in design teams as a strategy to solve implementation challenges identified in the needs and context analysis. The full realisation of CCD is contingent on how prepared teachers collaborate in design teams and how management of the educational institution is prepared to lend support to teachers in CCD. Hence the functionality of the activities of teams in CCD is dependent on the conditions working in design teams and management support. Thus the design and implementation stage spearheaded by CCD in design teams will result in product design (curriculum materials) where design teams would own the product and would see to its implementation (use) during internship. The impact stage seeks to ascertain how the activities of CCD in teams result in quality curriculum materials and sustainable internship practices. In addition the sustainability of CCD itself is studied during the impact stage.

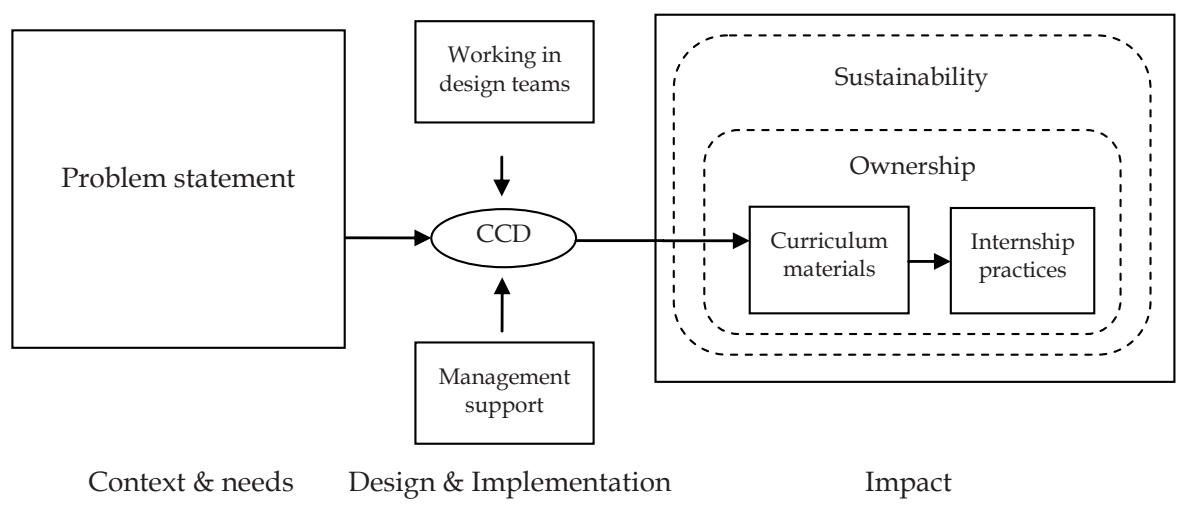

Figure 1.2 The model connecting the stages of the research to CCD

The context and needs study that serves as the driver to the entire research project by identifying the problems regarding organisation of student internship in the polytechnics in Ghana by the stakeholders (full account in chapter 2) gave direction to subsequent studies. In the bid to solving the problems, the first design and implementation study was executed in one of the polytechnics (Tamale Polytechnic) where CCD in design teams as a strategy was employed as a means to ensure that teachers collaborate in working teams with the support of 
polytechnic management to design curriculum materials for student internship (detail report in chapter 3). The second design and implementation stage, similar to the first, was carried out in another polytechnic (Takoradi) with the emphasis on ensuring that the curriculum materials designed are of quality (full report in chapter 4). Finally, after one-year and two-year periods of implementation of the interventionist studies ( $1^{\text {st }}$ and $2^{\text {nd }}$ design and implementation studies) respectively for Takoradi and Tamale Polytechnics, an impact study was carried out to ascertain the extent to which CCD has influenced the quality of the internship curriculum materials, student internship practices and how prepared are teachers and management representatives to continue with CCD as a means to improve curriculum in the polytechnics (full presentation in chapter 5). The supposition is that quality curriculum materials design in CCD and the positive influence on student internship practices could create ownership and eventually culminate in its (CCD) sustenance over time.

\subsection{RESEARCH APPROACH}

\subsubsection{Research questions and relevance}

In this dissertation a design research approach is followed. In the curriculum domain, design research is often selected to facilitate improved understanding of how to design for implementation. The design and research activities involve high participation from the target group (key stakeholders). By carefully studying the effect of the intervention in their target settings, insights are sought on how to build and implement consistent, harmonious, and coherent components of a robust curriculum (Collins, Joseph, \& Bielaczyc, 2004; McKenney, Nieveen, \& Van den Akker, 2006).

The aim of this research is therefore to investigate how CCD is adopted to design curriculum materials to improve student internship practices in the Department of HCIM. Based on this focal point, the central question is framed as follows. In which ways does collaborative curriculum design in design teams contribute to quality curriculum materials for sustainable student internship practices in the polytechnics? In addressing this question, a design-based research approach is adopted and four sub-questions are framed. 
1. What are the perceptions and suggestions among the various key stakeholders of HCIM education regarding student internship and its organisation?

Research question 1 investigates the state in which student internships are carried out within the Departments of HCIM by eliciting the perceptions and suggestions of students, alumni, teachers, management representatives and industry personnel on the organisation of student internship. The ultimate aim/goal is to identify the needs underlying the organisation of student internship and to elicit plausible suggestions for improvement (for detailed account see chapter 2).

2. Does collaborative curriculum design in design teams contribute to an improved curriculum for student internship?

As a follow-up study (to the first research question), collaborative curriculum design approach is adopted where teacher teams collaboratively designed curriculum materials in the bid to improve student internship. In this vein, the second research question is addressed. The detailed account is captured in the third chapter of this dissertation.

3. Do the curriculum materials produced by the design teams contribute to renewed student internship according to the stakeholders involved?

The third study attempts to answer research question 3 . The focus of this study is on the measures that are taken by the stakeholders to ensure quality curriculum materials were produced for use in the student internship. The underlying assumption is that quality curriculum materials with the support from the educational institution and industry could guarantee improved student internship. The full write-up is in chapter 4 .

4. To what extent does collaborative curriculum design lead to sustainable student internship practices according to the various stakeholders?

The fourth study addresses the fourth research question. The research purpose is to investigate the extent to which collaborative curriculum design and the curriculum materials have given rise to sustained improvement in the organisation of student internship and the resolution of implementation challenges and to explore the opinions of polytechnic teachers and management representatives towards CCD in design teams as a means to curriculum improvement. The full account is in chapter 5 . 


\subsection{STRUCTURE OF THE DISSERTATION}

This thesis comprises six chapters. The first chapter introduces the study. The context and needs analysis sub-study which explores the organisation of student internship in the Departments of HCIM in Ho, Kumasi, Takoradi and Tamale Polytechnics and results in suggestions for improvement in student internship from students, alumni, teachers, management representatives and industry personnel. The purpose of this study was to identify the challenges and needs in the organisation of student internship (second chapter). The third chapter highlights how teachers in the Department of HCIM, Tamale Polytechnic formed design teams to collaboratively design curriculum materials to address the implementation challenges identified in the context and needs assessment analysis study. The fourth chapter describes the measures stakeholders (students, teachers and industry representatives) took to ensure the design and development of quality curriculum materials to improve student internship in the hospitality industry. The site for this sub-study is the Department of HCIM at Takoradi Polytechnic. The fifth chapter presents the views of stakeholders (students, teachers, management representatives and industry personnel) of hospitality management programme on the impact of CCD in design teams, on the organisation of student internship and on the use of curriculum materials for student internship. Finally, the sixth chapter articulates findings and points for discussion, including reflections on the research approach and recommendations for further study. Instruments used for eliciting information from the sub-studies and the curriculum materials designed are captured in the appendices. 


\title{
CHAPTER 2
}

\section{Internship in vocational education and training: Stakeholders' perceptions of its organisation ${ }^{1}$}

\begin{abstract}
Polytechnic education in Ghana is an offshoot of technical and vocational education and training (TVET) which makes internship a sine qua non for its students. The implementation of internships in the Departments of Hotel Catering and Institutional Management (HCIM) in Ghanaian Polytechnics is examined in this study. The perceptions of the stakeholders suggest weak links between the educational institution and hospitality industry leading to ineffective implementation which culminates in myriad of challenges faced by interns. Finally, suggestions from stakeholders for improvement in subsequent internships were preparedness to collaborate, internship time to be extended, industry's and teachers' active participation in internship.
\end{abstract}

\subsection{INTRODUCTION}

Internship as a form of workplace learning is a vital component of many professional programmes in vocational education (Levesque et al., 2000). It can assist students to bridge the gap between the academic learning process and the practical reality (Lam \& Ching, 2006) by exposing them to real-life experience. The meaning of an internship and its operational definition can be different around the globe. As various types of training in the work environment have developed differently, the terminology in the field varies as well (Busby \& Gibson, 2010). Definition of internship is dependent on the cohort of students (interns) participating, its duration, type of employment, its ultimate objectives as well as

1 Akomaning, E., Voogt, J. M., \& Pieters, J. M. (2011). Internship in vocational educational education and training: Stakeholders' perceptions of its organisation. Journal of Vocational and Training, 63(4), 575-592. 
the context within which it is organised (Crnković-Pozaić, 2006). For example in the UK, the most frequently used term for the period of internship is "sandwich placement" (Busby, 2003), which can be defined as 'a temporary period of student employment as part of a student's course which is effectively planned and managed and takes in the negotiated requisites of the student, employer and HEI' [higher education institution] (Keynote Project, 2002, p. 5). Internships in the UK are effectively regulated by the code of practice for the assurance of academic quality and standards in higher education (Quality Assurance Agency, 2007). They are generally supported by the ASET (2009) guidelines regarding the duties of the academic institution, student and industry before, during and after internships. UK HEIs vary dramatically in their use of internships. The differences can be broken down between the pre 1992 universities that offer a very traditional style of research-based higher education with limited opportunities for internships and the post 1992 universities, which were originally polytechnics and offer internships in many of their courses (ASET, 2009).

In Ghana, the context of this study, the term 'industrial attachment' is often used to mean internship, to be considered an educational strategy where learning in the classroom alternates with learning in the workplace and allows for the competencies of students to be developed and nurtured by the mentors before students graduate (Effah, 2005). It offers interns in almost all fields an opportunity to gain professional experience in their area. It is predominantly unpaid, unregulated and domestically oriented (Effah, 2005). Working in a professional environment, interns develop a sense of responsibility as they interact with a wide range of age groups, meet potential role models and get feedback through performance assessment. However, in Ghana this form of linkage between theory and practice is still minimal and there are no established criteria for screening prospective interns (Effah, 2005). Usually internship is organised by educational institutions and students are supposed to comply with the start date and duration.

This study is aimed at identifying by means of a needs analysis the effective key components of internship as perceived by the relevant stakeholders from polytechnic students to hospitality industry personnel. The needs identified are assumed to be the building blocks of a curriculum for internship. 


\subsection{CONCEPTUAL FRAMEWORK}

In general, internship programmes are valuable ways to acquire broad competencies where practical knowledge obtained supports and complements the theoretical studies learned in the educational institutions (Mihail, 2006). This study is aimed at identifying the effective key components of internship as perceived by the relevant stakeholders from polytechnic students to hospitality industry personnel. Research identified relevant conditions that contribute to the benefits derived from internships and, when well managed, could create an authentic learning environment in the workplace for students. These conditions are: collaboration between school and industry (Divine et al., 2007), placement procedures (University of Pittsburgh 2009), duration and time (Divine et al., 2007; Mihail, 2006) and assessment procedures (Walo, 2001) which will culminate in the manner in which implementation is carried out (Lam \& Ching, 2006; McManus \& Feinstein, 2008). In this study we try to inventory the perceptions of stakeholders concerning to what extent these conditions are present in the internship practice in Ghana and how they can be improved.

Research has shown that effective collaboration between educational institutions and industry promotes successful internship (Divine et al., 2007) which emphasises interns' placement being relevant to their academic programme (Christou, 1999). This is an effective way of interns transferring newly acquired competencies to a real-life-test and better appreciative of their future career (Christou, 1999). There is no literature or empirical evidence on a specific duration for internship. However, duration for internships depends on objectives (Busby \& Gibson, 2010), nature and arrangements for the industrial training (Divine et al., 2007). Thus to every internship, there is a time period. Studies indicate that assessment by both industry and academic institution's supervisors provide an effective monitory of interns (Lam \& Ching, 2006; Walo, 2001; Waryszak, 2000).

School-industry collaboration has far-reaching effects. The impact of collaboration can generate new knowledge which can contribute to an industry's improved performance (Pertuzẻ, Calder, Greitzer, \& Lucas, 2010) during internship. Internship can promote learning alliances between industry and academia which can facilitate both flexibility and speed up innovation. The greater ability to identify and bring in external ideas and technologies enhances an industry's flexibility to respond to changing customer needs. A close collaboration gives rise 
to joint interest, ambition and purpose towards a shared vision (Kliknaite, 2009) in any well organised internship. Internship is often viewed as being mutually beneficial to the intern, the educational institution and the industry (Borkowski, 2008; Divine et al., 2007). The mutual benefits, nevertheless, cannot be guaranteed because its success or failure depends largely on the way in which the various stakeholders collaborate in its implementation process. Thus effective collaboration between the school and industry regarding student internship is a necessary condition to ensure success. For the school, internship can strengthen links with industry and better understand what business and industry expect from students while for industry internships can be an avenue for producing qualified candidates for the industry (Johnston, 2008). The success of internship depends on the collaboration between representatives of the industry, the school and the student (Clark, 2003; Schappert, 2005). These three parties need to agree on the conditions of the internship, the responsibilities of each party, and the reporting requirements. The reverse is true when the links between school and industry is episodic, it may lead to students performing menial tasks (Johnston, 2008), resulting in interns become quickly demoralized and will learn nothing about applying their expertise to a business environment. Therefore school, industry and student need to specify their distinctive roles during student internship (Rothman, 2007). It stands to reason that formalisation of links between industry and school will foster the collaboration. Christou (1999) indicates interns in hospitality operations acquired skills which enable them to be quite confident in their professional career in the first employment after graduation although encountered few hitches. Collaboration therefore plays a vital role in student learning in industry. Thus, internship well organised will help students to transit smoothly from school to industry (Carlin \& Manson, 2007).

Internship placements for interns can be categorised into two: managed and unmanaged or unstructured (Divine et al., 2007; Effah, 2005), haphazardly planned (McManus \& Feinstein, 2008). The former is where students have no freedom of choice but the school arranges by assigning students to different industries (Christou, 1999). In the case of the latter, students are allowed on their own to look for companies for themselves. Divine et al. (2007) argue that the unmanaged option has the advantage of students having firsthand knowledge about the labour market which becomes a source of information for future employment. They were however quick to state that a student who fails in the attempt may not get the chance of having internship experience. The ease with 
which students get access to industries to enrol will lessen delays and frustrations interns need to go through when searching for vacancies in industries for internship. Moreover, the relevance of the industry to students' major area of study will go a long way to advance their training (Walo, 2001). From the curriculum perspective, the managed option is preferable because the school makes sure students are placed in industries relevant to their field of study (League of Oregon Cities, 2009) and ensures coherence between what is taught in school and outside school (Walo, 2001).

The duration as well as the time of the year in which internships are organised varies across countries. A six-month period for internship is quite usual with academic institutions around the globe (Lam \& Xiao, 2000; Mihail, 2006; Walo, 2001). Generally, internship programmes in the USA provide two to a maximum of 18 months internship periods in relevant study programmes of interns (Internship USA, 2008) whilst in most European countries a minimum of three to maximum of 12 months (Aston University Careers and Employability Centre, 2009). In both geographical blocs placements are available all the year round which is similar to that of Singapore (Republic Polytechnic, 2008). Internship periods could be classified as full time and part-time (Divine et al., 2007). The full time option is where students do not engage in class work (lecturing) and internship concurrently but the part-time does. The full time option looks better than part-time because the latter is restrictive but the former is not. Students have the freedom to have their internship in a more widely geographical area in the case of full time because students break away from campus work hence no need to shuttle between class and internship (Divine et al., 2007).

To elicit what students have learned during their internship clear assessment requirements and procedures need to be in place. Students are assessed by both the academic institution's supervisor and industry's supervisor (Republic Polytechnic, 2008; Walo, 2001). Sometimes students have options to choose the type of assessments from the curriculum to carry out during internship (Clark, 2003). However, research on internship programmes has shown significant gaps in the expectations of students' job performance among students, school and industry (Lam \& Ching, 2006; Waryszak, 2000). Such chasms could be narrowed or bridged if there are shared curriculum materials, including a description of assessment criteria and procedures. 
Conditions for successful implementation of internship are characterised by strong collaboration between school and industry, a reasonable duration of the internship, clear placement and assessment procedures. Successful implementation of internship may be threatened by challenges students face during internship: non-payment of interns, lack of communication between employees and interns, an uncomfortable and hectic work environment, negative supervisor's attitude, lack of responsibility and limited opportunities (Collins, 2001). Such challenges were most probable in haphazardly planned internships (McManus \& Feinstein, 2008).

\subsection{VET AND HIGHER EDUCATION IN GHANA}

Polytechnics are part of the higher education system in Ghana and are primarily responsible for TVET at the tertiary level. Polytechnic education in Ghana started as second cycle institutions in the 1960s under the Ghana Education Service (Agodzo, 2007; Nsiah-Gyabaah, 2005). But in 1993 their status was changed from second cycle to tertiary cycle through the promulgation of the Polytechnic Law (PNDC Law 321). It should be noted that the change in status did not change the facilities nor an upgrade of the staff to commensurate the new status. Currently, Ghana has 10 polytechnics (offering different academic programmes of both second and tertiary courses). All are state-owned and are vocational in orientation, offering applied programmes in the sciences, technology and business management leading to the award of the Higher National Diploma (HND).

The polytechnic system in Ghana has not received the requisite attention it deserves to enable the sector contributes effectively to national human development which is so vital for establishing a productive and skilled workforce for Ghana's development (OXIA Ghana Limited, 2004). The TVET curriculum is institution-based, supply-driven and regarded as being out-of-date and not responding to the demands of the labour market (Akyeampong, 2010). The mismatch between institutional training and the needs of industry has serious implications for Ghana's economy and the employability of graduates from the TVET institutions especially the polytechnics. Research from Boateng and OforiSarpong (2002) revealed that industries were enthused in contributing to student internship. In spite of the enthusiasm demonstrated by Ghanaian industries toward polytechnic internships, the collaboration between both entities lacks joint interest, ambition and vision (Kliknaite, 2009) to propel effective industrial 
training of students. Internships in the polytechnics are restrictive in the sense of placements and time, and beset with challenges because they are haphazardly planned (McManus \& Feinstein, 2008).

\subsection{CONTEXT OF THE STUDY}

Polytechnics have been the responsive institution of choice by the government to meet the middle level manpower needs of commerce and industry and public demand for access to tertiary education has increased in response to this need. To better prepare students for the labour market, a six-month mandatory internship forms an integral part of a three-year polytechnic education in Ghana (Effah, 2005). In Ghana, industries are under no obligation to draw up a training programme for potential interns. Moreover, there is no policy on industries being compelled to give feedback on interns to polytechnics which counter to the dictates of structured internships (McManus \& Feinstein, 2008). Internship activities in the polytechnics are under the auspices of the Industrial Liaison Unit (ILU) in each polytechnic. The nature of the internship is described as unstructured by Effah (2005).

The Department of Hotel Catering and Institutional Management (HCIM) is responsible for training students to assume managerial or supervisory roles in the hospitality industry in Ghana and beyond. Four of such academic departments in Ho, Kumasi, Takoradi and Tamale Polytechnics form part of the study. The HCIM programme is a three-year tertiary programme which commenced in 1993. Entrants into the programme are predominantly those who have successfully completed the Home Economics programme at the senior secondary school. Successful students graduate with the award of the HND certificate in hospitality management.

Teaching and learning are supposed to be a blend of theoretical and practical lessons. In order to fulfil this mandate, internship programmes are organised for students where they apply to industries of their choice. Internship programmes are carried out in two sessions throughout the three-year programme. Each session spans a period of three months at the end of every academic year. So, in all students are supposed to make at least six months throughout the entire study period of three years. These internship periods are supposed to be supervised by both polytechnic educators and industry representatives. In order to facilitate the internship programmes, each polytechnic has the ILU whose primary responsibility is to ensure that students have places to carry out internship. 
In this study, teachers, alumni and students of the HCIM department, management representatives of the polytechnics and hospitality industry personnel were questioned about their perceptions of student internship. Stakeholders' views on collaboration, placement (access and relevance to the workplace), duration of internship, assessment procedures, the overall student internship implementation, the challenges students face during internship and suggestions for improvement in subsequent internships were elicited from respondents. The main research question is: What are the perceptions and suggestions among the various key stakeholders of HCIM education regarding student internship and its organisation? The study is guided by the following sub-questions:

1. To what extent do the perceptions of stakeholders differ regarding collaboration, placement, duration and assessment of internship for HCIM students?

2. What are the implementation challenges student internship faces?

3. What are the suggestions to improve internship for HCIM students?

\subsection{METHODS}

\subsubsection{Respondents}

The Departments of HCIM in four polytechnics were involved in the study. From each polytechnic second and third year HND students were randomly selected to participate: Ho, $N=40$; Kumasi, $N=30$; Takoradi, $N=60$ and Tamale, $N=30$. Forty alumni selected (through snowball approach) comprising 10 each from the respective departments form part of the respondents. In addition, 20 hospitality industry representatives (five per polytechnic) were purposively selected based on where students carry out internship and accessibility. Deans of Schools of Applied Science $(N=4)$, members of the academic board $(N=4)$ and industrial liaison officers $(N=4)$ (hereafter referred to as management representatives) from the polytechnics were part of the study. Finally, all teachers $(N=45$ : Ho, $N=12$, Kumasi, $N=10$, Takoradi, $N=15$, Tamale, $N=8$ ) in the respective HCIM departments constitute part of the study. Teachers, students and management representatives were all given questionnaires and the response rates were $73 \%$, $100 \%$ and $92 \%$ respectively. Alumni and hospitality industry representatives were each given a questionnaire. The response rate in each case was $100 \%$. 


\subsubsection{Instrumentation}

Sets of questionnaires were administered to all the respondents. Question items were predominantly in a five-point Likert scale using responses graded: 5 strongly agree, 4 agree, 3 neutral, 2 disagree and 1 strongly disagree to determine the level of agreement to statements. A few questions were open-ended and respondents were asked to respond to them appropriately. The open and close-ended questions aimed at gathering information about the four effective conditions: collaboration, placements, duration, and assessment, and the characteristics of implementation challenges and suggestions for improvement of internships (Table 2.1; see Appendices A1, A2, A3, A4 and A5).

Table 2.1 Overview of the constructs and example questions/statements

\begin{tabular}{|c|c|}
\hline Construct/concept & Question/statement \\
\hline Collaboration & $\begin{array}{l}\text { The hospitality industry collaborates with teachers of the Department of } \\
\text { HCIM in the training of the students; There should be closer collaboration } \\
\text { between all key stakeholders of HCIM education in the polytechnics. }\end{array}$ \\
\hline Placement & $\begin{array}{l}\text { HCIM students find placement in organisations which are related to } \\
\text { their course areas of study during internship; Where did you do your } \\
\text { first internship? }\end{array}$ \\
\hline Duration & For how long was the internship period? \\
\hline Assessment & $\begin{array}{l}\text { Students are made to write reports on their experience on internship; } \\
\text { Employers are generally satisfied with the job performance of HCIM } \\
\text { students on internship. }\end{array}$ \\
\hline Implementation & Internship programme for HCIM students is well implemented. \\
\hline Challenges & What challenges did you face during internship? \\
\hline Suggestions & $\begin{array}{l}\text { Hospitality industry should redouble their support in the training of } \\
\text { HCIM students; Time for internship programme for HCIM students } \\
\text { should be extended. }\end{array}$ \\
\hline
\end{tabular}

\subsection{RESULTS}

\subsubsection{Perspectives of stakeholders: Collaboration}

Perceptions of stakeholders

The stakeholders' views on involvement in internship in the Departments of HCIM are presented in Table 2.2. Regarding the links between hospitality industry representatives and teachers in the training of students, the means 
ranged from 2.7 to $3.6(F=2.007, p=0.09, n s)$. Apparently stakeholders did not differ in their views concerning collaboration. The highest mean went for management representatives with standard deviation of .81 and the least alumni. Perceived relatively low means from students, alumni and teachers could imply links between the department and industry might be weak which might stem from roles of the stakeholders not clearly specified; a probable characteristic of haphazardly planned internship (McManus \& Feinstein, 2008). Industry's response is quite refreshing which confirms the extent of preparedness by Ghanaian industries towards student industrial training (Boateng \& OforiSarpong, 2002). Formalisation of links between industry and polytechnic will foster joint interest and vision (Kliknaite, 2009) that will create a congenial platform for ensuring that students were well trained.

Table 2.2 Views of stakeholders on involvement of internship

\begin{tabular}{|c|c|c|c|c|c|}
\hline Statement & $\begin{array}{l}\text { Student } \\
(n=160)\end{array}$ & $\begin{array}{c}\text { Alumni } \\
(n=40)\end{array}$ & $\begin{array}{c}\text { Teacher } \\
(n=33)\end{array}$ & $\begin{array}{c}\text { Management } \\
\text { representatives } \\
\quad(n=11)\end{array}$ & $\begin{array}{c}\text { Industry } \\
\quad(n=20)\end{array}$ \\
\hline $\begin{array}{l}\text { The hospitality industry } \\
\text { collaborates with teachers of } \\
\text { the Department of HCIM in the } \\
\text { training of the students. }\end{array}$ & $\begin{array}{c}3.0 \\
(1.32)\end{array}$ & $\begin{array}{c}2.7 \\
(1.23)\end{array}$ & $\begin{array}{c}2.9 \\
(1.21)\end{array}$ & $\begin{array}{l}3.6 \\
(.81)\end{array}$ & $\begin{array}{c}3.5 \\
(1.10)\end{array}$ \\
\hline $\begin{array}{l}\text { HCIM students find placements } \\
\text { in organisations which are } \\
\text { related to their course areas of } \\
\text { study during internship. }\end{array}$ & $\begin{array}{c}3.7 \\
(1.24)\end{array}$ & $\begin{array}{c}3.6 \\
(1.22)\end{array}$ & $\begin{array}{c}4.0 \\
(.85)\end{array}$ & $\begin{array}{c}4.0 \\
(.88)\end{array}$ & $\begin{array}{c}4.1 \\
(.89)\end{array}$ \\
\hline $\begin{array}{l}\text { The time earmarked for } \\
\text { internship programme is } \\
\text { sufficient for HCIM students to } \\
\text { realize the goals and objectives in } \\
\text { the national HCIM curriculum. }\end{array}$ & $\begin{array}{c}3.0 \\
(1.31)\end{array}$ & $\begin{array}{c}3.2 \\
(1.23)\end{array}$ & $\begin{array}{c}2.6 \\
(1.32)\end{array}$ & $\begin{array}{c}3.1 \\
(1.30)\end{array}$ & $\begin{array}{c}3.1 \\
(1.13)\end{array}$ \\
\hline
\end{tabular}

Note: Figures in parentheses are standard deviations; figures not in parentheses are means; $\mathrm{n}$ is sample size; rating scale: 1 , strongly disagree; 2 , disagree; 3 , neutral; 4 , agree; 5 , strongly agree.

\subsubsection{Perspectives of stakeholders: Placements}

As seen in Table 2.2, stakeholders generally agreed to the statement that students largely found internships in industries which were related to their study programme - means ranged from 3.6 to $4.1(F=0.901, p=0.46, n s)$. Industry representatives recorded the highest mean of 4.1 indicating that they agreed to the 
statement that students find placements at appropriate industries which relate to their study programme during internship. In a related issue on where students did their previous year's internship, majority of the students (about $78 \%$ ) took up internship in the hospitality industry and about 20 percent found placement in health centres. It is important to note that interns practise in the appropriate industries which relate to their study programme. Interns' ability to blend theory with practice better prepares them for their careers. In spite of this result, it should be noted that there is still room for improvement. In some instances, students fail to proceed on internship due to limited number of vacancies. Students were asked where they had their first internship. The responses were as follows: $61 \%$ (98) did indicate they had it in hotels, guesthouses and restaurants whilst 17\% (27) stated health centres and 1\% other companies. However, $21 \%$ (33) did not participate in internship due to the limited number of access to industries which could characterise unstructured internship (Effah, 2005).

\subsubsection{Perspectives of stakeholders: Duration}

Officially, it was expected that each student embarks on at least six months internship throughout the three-year HCIM programme which is in consonance with other studies (Christou, 1999; Lam \& Xiao, 2000). Thus three months each after first and second year. Majority of the students in both first (47\%) and second (51\%) internship periods spent four weeks. About $13 \%$ of the students in each period spent six weeks whereas 28 percent and 16 percent of the respondents spent eight weeks respectively for first and second periods of internship. Some interns (6 to $8 \%$ ) spent periods between two and three weeks. Only $2 \%$ of the second year students and $10 \%$ of the third year students could satisfy the mandatory period of three months for first and second periods of internship. If about 6 percent of the students on average could satisfy the mandatory period, then, there is cause for concern. So, most students spent less time in internship than was planned in the curriculum. Bottlenecks associated with internship were limited number of places for internship, students' lack of information regarding available places (in the absence of search engines and websites), and students' preparations toward internship which eat into the already relatively short summer break. Stakeholders did not differ in their perception of time spent during internship -2.6 to $3.2(F=0.899, p=$ $0.47, n s)$, but the means were relatively low. Students were neutral regarding the time that was earmarked for internship programme (mean=3.0). Alumni were ranked the highest, slightly above students, with a mean of 3.2. Management and 
industry representatives had the same mean of 3.1. Teachers were least on the agreement scale with a mean of 2.6 (Table 2.2).

\subsubsection{Perspectives of stakeholders: Assessment}

With respect to students writing reports on their experience while on internship, all the stakeholders unanimously agreed to the statement (Table 2.3). The means ranged from 4.1 to $4.5(F=1.489, p=0.21, n s)$. Stakeholders were very certain of students writing reports on their industrial experience during internship (means ranging from 4.1 to 4.5 and standard deviations between .83 and 1.02). A follow-up statement was student internship reports form part of students' assessment. In response to this statement, all stakeholders (does not apply to industry) responded in the affirmative with means between 3.8 and $4.1(F=0.252, p=0.86, n s)$. The interns wrote reports and these were assessed by teachers. So, regarding assessment, Ghana's practice is similar to practices elsewhere (Clark, 2003; Walo, 2001).

Table 2.3 Views of stakeholders on assessment of internship

\begin{tabular}{|c|c|c|c|c|c|}
\hline Statement & $\begin{array}{l}\text { Student } \\
(n=160)\end{array}$ & $\begin{array}{l}\text { Alumni } \\
(n=40)\end{array}$ & $\begin{array}{l}\text { Teacher } \\
(n=33)\end{array}$ & $\begin{array}{l}\text { Management } \\
\text { representative } \\
\quad(n=11)\end{array}$ & $\begin{array}{l}\text { Industry } \\
(n=20)\end{array}$ \\
\hline $\begin{array}{l}\text { Students are made to write } \\
\text { reports on their experience on } \\
\text { internship. }\end{array}$ & $\begin{array}{c}4.5 \\
(.87)\end{array}$ & $\begin{array}{c}4.2 \\
(1.02)\end{array}$ & $\begin{array}{c}4.4 \\
(.83)\end{array}$ & $\begin{array}{c}4.1 \\
(.94)\end{array}$ & $\begin{array}{c}4.3 \\
(.85)\end{array}$ \\
\hline $\begin{array}{l}\text { Student internship reports form } \\
\text { part of students' assessment. }\end{array}$ & $\begin{array}{c}4.0 \\
(1.13)\end{array}$ & $\begin{array}{c}4.1 \\
(1.11)\end{array}$ & $\begin{array}{c}4.1 \\
(1.10)\end{array}$ & $\begin{array}{c}3.8 \\
(1.22)\end{array}$ & - \\
\hline $\begin{array}{l}\text { Employers are generally satisfied } \\
\text { with the job performance of } \\
\text { HCIM students on internship. }\end{array}$ & - & $\begin{array}{l}3.9 \\
(.92)\end{array}$ & $\begin{array}{l}3.8 \\
(.85)\end{array}$ & - & $\begin{array}{l}3.4 \\
(.94)\end{array}$ \\
\hline
\end{tabular}

Note: Figures in parentheses are standard deviations; figures not in parentheses are means; $\mathrm{n}$ is sample size; rating scale: 1 , strongly disagree; 2 , disagree; 3 , neutral; 4 , agree; 5 , strongly agree.

The last statement on assessment looks at the views of alumni, teachers and industry on the extent of satisfaction of jobs performed by students when on internship. Both alumni (mean=3.9) and teachers (mean=3.8) contended that employers were generally quite satisfied with the job performance of students. Industry representatives were the least ranked on satisfaction with job performance of students during internship with mean of $3.4(F=1.853, p=0.16$, $n s)$. The means suggest there were no significant differences among stakeholders. The means of alumni and teachers may imply that they were quite confident in 
their students for rendering satisfactory jobs in industry. A percentage rating of $55 \%$ of industry respondents in total agreeing to the statement is quite positive.

The hospitality industry (predominantly private sector owned) in Ghana was quite satisfactory with HCIM students. However, the private sector employs a relatively low number $(25 \%)$ of alumni whilst in the public sector, particularly in the health and the education, as high as about $67 \%$ were employed. The figures confirm the study by Boateng and Ofori-Sarpong (2002) that in Ghana graduates from tertiary institutions prefer to work in public sector (job security is guaranteed and career progression is favourable) than in the private. Table 2.4 summarises the perceptions of stakeholders regarding student internship.

Table 2.4 Summary of perceptions of stakeholders regarding internship

\begin{tabular}{|c|c|}
\hline Condition & Remarks \\
\hline Collaboration & Industry-polytechnic links (HCIM departments) need to be strengthened \\
\hline Placement & $\begin{array}{l}\text { Relevant to interns' academic programme but about } 20 \% \text { couldn't go } \\
\text { through internship }\end{array}$ \\
\hline Duration/time & $\begin{array}{l}\text { Relatively shorter than required; About } 50 \% \text { of students spent } 4 \text { weeks; only } \\
6 \% \text { on average did meet target period }\end{array}$ \\
\hline Assessment & $\begin{array}{l}\text { Stakeholders unanimously concurred students wrote reports about their } \\
\text { industrial experience; Reports were assessed by teachers; Job performance of } \\
\text { students on internship was quite satisfactory }\end{array}$ \\
\hline
\end{tabular}

In conclusion, the stakeholders' views on collaboration, placement, duration and assessment did not differ. However, the relatively low means (2.7 to 3.6) on the issue of collaboration suggest that linkage between the department and industry need to be strengthened. Duration for internship was too short; students hardly fulfil the mandatory period earmarked for internship. Placement of students in industries which relate to their academic programme was encouraging. Assessment of students' industrial experience in the form of report writing was known to all stakeholders. They held the views that employers were quite satisfied with the job performance of interns during internship. It should however be noted that all views expressed suggest there is room for interns to improve on their competencies if the roles of stakeholders were clearly defined and delineated with appropriate policy directives that ensure all key stakeholders were committed to the empowering of interns with employable competencies. 
Implementation challenges facing students

Stakeholders' views on implementation of internship programme did not differ (Table 2.5). The mean values ranged from 3.0 to 3.6 with standard deviation between the magnitude of 1.20 and $1.42(F=0.489, p=0.69, n s)$. It is interesting to note that when it comes to implementation of internship programme for students only management representatives quite agreed (3.6) to the statement but the rest (does not apply to industry) remained neutral. The means of students in the four polytechnics ranged from 2.3 and $3.5(F=5.263, p=0.002)$. Tukey's post hoc test reveals that there was a significant difference between students of Kumasi and Takoradi $(p=0.001)$.

Table 2.5 Views of stakeholders on implementation of internship

\begin{tabular}{lc|ccc|} 
Statement & $\begin{array}{c}\text { Student } \\
(n=160)\end{array}$ & $\begin{array}{c}\text { Alumni } \\
(n=40)\end{array}$ & $\begin{array}{c}\text { Teacher } \\
(n=33)\end{array}$ & $\begin{array}{c}\text { Management } \\
\text { representatives } \\
(n=11)\end{array}$ \\
\hline $\begin{array}{l}\text { Internship programme for HCIM } \\
\text { students is well implemented. }\end{array}$ & 3.1 & 3.0 & 3.1 & 3.6 \\
\hline
\end{tabular}

Note: Figures in parentheses are standard deviations; figures not in parentheses are means; $\mathrm{n}$ is sample size; rating scale: 1 , strongly disagree; 2 , disagree; 3 , neutral; 4 , agree; 5 , strongly agree.

Table 2.6 shows the challenges that students face during internship. Challenges like unfriendly relationship between industrial staff and students and unwillingness of industrial staff to teach interns constitute 25\%. Industry's failure to provide transport and high transportation fares to and from industry and lack of accommodation for interns was $16 \%$. Other challenges were no proper training during internship constitutes $15 \%$ whilst $13 \%$ stated they were restricted to some departments/sections of industry and restricted to one activity (particularly, duties like slicing of vegetables and washing of dishes).

Table 2.6 Students' views on challenges faced during internship

\begin{tabular}{|lcc|}
\hline Response $(n=157)$ & Frequency & Percentage \\
\hline $\begin{array}{l}\text { Unfriendly relationship and unwillingness of industrial staff } \\
\text { to teach students }\end{array}$ & 69 & 25 \\
\hline Lack of transportation and accommodation & 44 & 16 \\
\hline No proper training and supervision & 42 & 15 \\
\hline Restricted to one department/section and one activity & 37 & 13 \\
\hline Unqualified staff and lack of modern facilities & 29 & 10 \\
\hline No allowance given to students & 29 & 10 \\
\hline Limited time and difficult getting placement & 21 & 7 \\
\hline Academic staff and industry inability to monitor internship & 10 & 4 \\
\hline Total & 281 & 100
\end{tabular}

Note: Some respondents indicated more than one response; $n$ is sample size 
In all, about $10 \%$ each of the students indicated unqualified industrial staff and lack of modern facilities, and no allowance given to students after internship. Other equally important challenges that need to be addressed were limited time for internship and difficulty in obtaining placements and lack of monitoring by both academic staff and industrial staff. These challenges had percentage ratings of between $4 \%$ and $7 \%$. These challenges are usually symptomatic of unstructured internship.

Table 2.7 shows a summary of stakeholders' perceptions about well implemented internship and challenges faced by students during internship.

Table 2.7 Summary of implementation challenges

\begin{tabular}{|c|c|}
\hline Status/Challenge & Remarks \\
\hline Status of implementation & $\begin{array}{l}\text { Stakeholders were quite hesitant to the well implementation of } \\
\text { internship; perceptions on implementation did not differ } \\
\text { generally }\end{array}$ \\
\hline Social & Uncooperative nature of industrial staff constitutes $25 \%$ \\
\hline Economic & $\begin{array}{l}\text { Lack of transportation and accommodation ( } 16 \%) \text { and non- } \\
\text { payment of allowance (10\%) summing up to } 26 \%\end{array}$ \\
\hline Technical deficiency & Limited time and placement constitute $7 \%$ \\
\hline $\begin{array}{l}\text { Professional } \\
\text { commitment }\end{array}$ & $\begin{array}{l}\text { Lack of professional commitment on the part of industry and } \\
\text { teachers sums up to }(15+13+10+4) 42 \% \text {. }\end{array}$ \\
\hline
\end{tabular}

To sum up, students faced a catalogue of challenges during internship. These challenges could be categorised as social, economic, technical deficiency and lack of professional commitment.

Suggestions to improve internship

Stakeholders responded to statements regarding suggestions for improvement in implementation of internships. The purpose of these statements was to determine how prepared stakeholders were towards subsequent internships. The statements are given in Table 2.8 . 
Table 2.8 Stakeholders' suggestions for improvement on implementation of internship

\begin{tabular}{|c|c|c|c|c|c|}
\hline Statement & $\begin{array}{l}\text { Student } \\
(n=160)\end{array}$ & $\begin{array}{l}\text { Alumni } \\
(n=40)\end{array}$ & $\begin{array}{c}\text { Teacher } \\
(n=33)\end{array}$ & $\begin{array}{c}\text { Management } \\
\text { Representative } \\
\quad(n=11)\end{array}$ & $\begin{array}{c}\text { Industry } \\
(n=20)\end{array}$ \\
\hline $\begin{array}{l}\text { Hospitality industry should } \\
\text { redouble their support in the } \\
\text { training of HCIM students. }\end{array}$ & $\begin{array}{c}4.5 \\
(.92)\end{array}$ & - & $\begin{array}{c}4.3 \\
(.73)\end{array}$ & $\begin{array}{c}3.7 \\
(1.11)\end{array}$ & $\begin{array}{c}4.1 \\
(.91)\end{array}$ \\
\hline $\begin{array}{l}\text { Time for internship programme } \\
\text { for HCIM students should be } \\
\text { extended. }\end{array}$ & $\begin{array}{c}3.8 \\
(1.41)\end{array}$ & $\begin{array}{c}3.9 \\
(1.12)\end{array}$ & $\begin{array}{c}4.4 \\
(.82)\end{array}$ & $\begin{array}{c}3.7 \\
(.79)\end{array}$ & $\begin{array}{c}4.3 \\
(.66)\end{array}$ \\
\hline $\begin{array}{l}\text { HCIM teachers should actively } \\
\text { involve themselves in student } \\
\text { internship programme }\end{array}$ & $\begin{array}{c}4.3 \\
(.89)\end{array}$ & - & $\begin{array}{c}4.3 \\
(.78)\end{array}$ & $\begin{array}{c}4.0 \\
(1.21)\end{array}$ & $\begin{array}{c}4.4 \\
(.75)\end{array}$ \\
\hline $\begin{array}{l}\text { There should be closer } \\
\text { collaboration between all key } \\
\text { stakeholders of HCIM education } \\
\text { in the polytechnics. }\end{array}$ & $\begin{array}{c}4.4 \\
(.80)\end{array}$ & $\begin{array}{c}4.4 \\
(.75)\end{array}$ & $\begin{array}{c}4.7 \\
(.47)\end{array}$ & $\begin{array}{c}4.1 \\
(1.21)\end{array}$ & $\begin{array}{c}4.7 \\
(.47)\end{array}$ \\
\hline
\end{tabular}

Note: Figures in parentheses are standard deviations; figures not in parentheses are means; $n$ is sample size; rating scale: 1 , strongly disagree; 2 , disagree; 3 , neutral; 4, agree; 5 , strongly agree.

\subsubsection{Perspectives of stakeholders: Support}

The suggestions for improvement on implementation of internship are shown in Table 2.8. All stakeholders unanimously supported the idea that industry should redouble their support in the training of students, means ranged from 3.7 to 4.5 with standard deviations within the magnitude of .73 and 1.11. ANOVA test showed there were differences in views between the four stakeholders that suggest significance $(F=2.978, p=0.03)$. The significant difference between students' and management representatives' views on industry redoubling their effort in the training of students may be due to the fact that the former is directly affected by whatever goes on during internship and for that matter may show more interest in that regard than the latter who is quite remote. There was also a significant difference between teachers to the statement $(F=3.152, p=0.040)$. Tukey's post-hoc test reveals that the difference between teachers in Kumasi and Tamale. Kumasi is situated at the southern part of Ghana which is well endowed with social infrastructure whereas Tamale to the north is generally less endowed. The implication being that the latter was keener in receiving support from industry than the former. In related issues on what specific functions stakeholders would like to perform to improve teaching and learning; about 33 percent of the teachers indicated the need for stakeholders to organise internship for students 
and teachers. About 95 percent of industry representatives expressed the need to provide practical training for students in order to realize the objectives in curriculum in students whilst 60 percent of them indicated the promotion of student internship programme.

\subsubsection{Perspectives of stakeholders: Time extension}

Stakeholders saw the need for time for internship programme to be extended. The means of 3.7 to $4.4(F=1.914, p=0.11, n s)$ amply demonstrate the extent to which respondents agreed to the extension of time (Table 2.8). Means of 4.4 and 4.3 respectively for teachers and industry further suggest they were more optimistic to extension of time than the students, alumni and management representatives. The extension of time will be made possible if polytechnics would restructure their academic semesters and adopt the flexible internship times practice elsewhere (Republic Polytechnic, 2008; University of Pittsburgh, 2009).

However, there were significant differences in means between alumni of Ho (3.2), Takoradi (3.4) and Kumasi (4.6) [ $F=5.123, p=0.005]$. The implication is that Ho and Takoradi did not see the extension of time as crucial as compared to Kumasi. Further deduction could be made, it might be that alumni of Ho and Takoradi had better planned and executed internships than Kumasi. Tukey's post-hoc test reveals that there were significant differences between alumni of Ho and Kumasi $(p=0.011)$, and Kumasi and Takoradi $(p=0.037)$. It is crucial to note that the extension of time in itself is not the solution to students being equipped with attitudes, knowledge and skills, but the import of what goes on during internship. One way of overcoming the problem of duration is to restructure the academic semesters (which is currently 16 weeks per semester) in order to create longer summer vacations for internship time, or to adopt the practices in other countries where internships are available all the year round (Republic Polytechnic, 2008; University of Pittsburgh, 2009).

\subsubsection{Perspectives of stakeholders: Teacher involvement}

It goes without saying that the role of the teacher in the HCIM programme like all other academic programmes cannot be overemphasised. In response to the statement; teachers should actively be involved in internship programme, stakeholders unanimously answered in the affirmative. The means ranged from 4.0 to 4.4 with standard deviations within the bounds of .75 and $1.21(F=0.526$, 
$p=0.67, n s)$. If teachers have expressed the desire to actively participate in internship then the academic institutions should endeavour to mobilise adequate funds to meet the financial implications.

\subsubsection{Perspectives of stakeholders: Closer collaboration}

Table 2.8 also addresses the need for closer collaboration among all key stakeholders of HCIM education. All stakeholders agreed without any reservations that there should be closer collaboration. The means of 4.1 and 4.7 attest to it $(F=2.248, p=0.06, n s)$. In related issues on what specific functions respondents would like key stakeholders to perform so as to improve teaching and learning; about 27 percent of the teachers stated that challenges facing the polytechnics could be overcome through effective collaborative efforts among stakeholders. Added to that 20 percent indicated effective collaboration among stakeholders as channel through which teaching and learning can be improved. About 46 percent of management representatives indicated that industry should create avenue for students internship and moreover, to employ them after graduation. About 18 percent suggested well-structured internship programme and 27 percent suggested effective collaboration among stakeholders.

Suggestions from stakeholders regarding organisation of student internship have been summarised in Table 2.9.

Table 2.9 Summary suggestions for improvement on implementation of internship

\begin{tabular}{ll} 
Suggestion & Remarks \\
\hline Industry support & $\begin{array}{l}\text { Stakeholders were positive toward hospitality industry redoubling } \\
\text { support in the training of students; There was a significant } \\
\text { difference in views expressed by management representatives and } \\
\text { students. }\end{array}$ \\
\hline Time extension & $\begin{array}{l}\text { Stakeholders unanimously agreed to the extension of internship } \\
\text { period. }\end{array}$ \\
\hline Teacher involvement & $\begin{array}{l}\text { Stakeholders concurred that teachers should actively involve in } \\
\text { internship. }\end{array}$ \\
\hline Closer collaboration & $\begin{array}{l}\text { Stakeholders were of the opinion that there should be closer } \\
\text { collaboration among them. }\end{array}$
\end{tabular}

In summary, stakeholders did not differ in their views regarding suggestions for improvement except in the area of support where the difference was significant between students' and management representatives' views. Stakeholders saw the 
need for internship activities to be reinvigorated so as to achieve the intended objectives in the curriculum. They did not differ in their views concerning extension of time however, teachers and industry were more optimistic. To industry, internship is a means through which potential workers are subsequently employed. It is also a way of 'employing' cheap labour so extension of time for internship accrues to the benefit of industry. Alternatively, teachers feel more satisfied if their students fit in the labour market after graduation hence may clamour for more time for internship. Conversely, students who did not benefit from internship may frown on extension of time. All stakeholders suggested teacher active involvement in internship programmes as laudable.

\subsection{CONCLUSION AND DISCUSSION}

This study aimed at getting a better understanding of stakeholders' perceptions and suggestions of student internship in the HCIM curriculum. Generally, stakeholders' perceptions on collaboration, placement, duration and assessment did not differ. Institutional collaboration between polytechnic and industry to foster student internship needed to be strengthened. HCIM students usually did their internship in industries relevant to their study programme and students were assessed based on a report written about their experience in industry. Students faced challenges like social, economic, technical deficiency and lack of professional commitment during internship. Despite these challenges, the views of alumni, teachers and industry did not differ regarding the satisfaction of employers toward job performance of interns during internship. Stakeholders did not differ in their views regarding suggestions for improvement except in the area of support where there was significant difference between students' and management representatives' views. Stakeholders perceived extension of time for internship critical for interns' learning.

From the data gathered, it could be inferred that relationship between teachers and industry was weak. With collaboration not formalised between them (Effah, 2005), it is likely that both the polytechnics and industry did not understand their distinctive roles when it came to student internship. There is real cause for concern if about $20 \%$ of students did not carry out internship because of limited number of vacancies in industries for placement and $6 \%$, on the average, could satisfy the six-month mandatory period for internship. Stakeholders were 
unanimous on assessment of interns but if the relationship between the polytechnics and industry was episodic (Johnston, 2008), then, the kind of assessment (Clark, 2003; Walo, 2001) could be questionable. Effective assessment should involve closer collaboration of teachers, industry and interns with clearcut objectives spelt out which would improve on feedback system and thereby hone the competencies of interns. By so doing, stakeholders would be much more satisfied with the job performance of interns. In the absence of a collaborative curricular material jointly prepared by teachers and industry to help guide stakeholders, interns are bound to face myriad of challenges which eventually result in stakeholders being less satisfied with job performance of interns (Collins, 2001). It is however refreshing stakeholders' suggestions for improvement inspire confidence in future implementation of internship.

In order to articulate the proposition that internship is mutually beneficial to all stakeholders, the onus lies on stakeholders to collaborate effectively in ensuring that the proposition is materialised. Active teacher involvement in internship programme is paramount. A policy directive specifying the functions of each stakeholder could guarantee that authentic learning environment for interns' training. In a follow-up study, teachers, industry and students will jointly prepare curriculum material that may help streamline the implementation of internship with the view of improving internship. If stakeholders collaboratively prepare the material, it is believed they may consider the curriculum as their own product and not 'imposed' on them (Van den Akker, 2003). A grassroot approach to curriculum design is likely to promote implementation because participants who craft the document may also implement and evaluate. The hope of Ghana becoming tourist country of choice may be a reality if the human resource in the tourism and hospitality industry is given the needed impetus. In spite of the fact that this study has its limitations, and for that matter findings are tentative, the study provides baseline information for subsequent study which is geared toward managed internship (Divine et al., 2007). 


\title{
CHAPTER 3
}

\section{Towards a renewed student internship in Ghana's polytechnics: Through collaborative curriculum design in design teams ${ }^{2}$}

\begin{abstract}
Ghanaian polytechnics were designed to equip students with competencies that make them easily employable or set-up their own businesses. In order to fulfil this mission, the study tried to improve internship practices at the Department of Hotel Catering and Institution Management (HCIM), Tamale Polytechnic by teachers collaboratively designing curriculum materials which were used in student internship. Teachers appreciated to be involved in collaborative curriculum design to design curriculum materials for internship but regretted not being able to supervise students during their internships. Internship practices improved and interns received the cooperation of industry. Interns improved their competencies significantly compared to those students who did not go through internship.
\end{abstract}

\subsection{INTRODUCTION}

The role of teachers in curriculum development, particularly, in tertiary education cannot be underestimated. Promising educational projects have failed because teachers were alienated in the educational reform at the commencement (Doyle \& Ponder, 1975). It is therefore imperative to involve teachers at the various phases of educational reforms because of their training, role and position in education system, they are in a better position to understand when and how subject matter should be taught (Fullan, 2007). However, in this time and age when the quality of tertiary graduates has become a subject of public discussion, it is equally important

2 Akomaning, E., Voogt, J. M., \& Pieters, J. M. (Submitted). Towards a renewed student internship in Ghana's polytechnics: through collaborative curriculum design in design teams. Journal of Higher Education Research \& Development. 
to involve other stakeholders in curriculum development, so that the product(s) that would be designed are not perceived by other stakeholders as imposition (Van den Akker, 2003) and therefore lack credibility during implementation. The shared responsibility becomes even more crucial when the development of the curriculum pertains to an internship programme where educational institutions and industry closely need to cooperate to make it a successful learning experience for students. Thus stakeholders collaborative planning where needs and interests of stakeholders are elicited become paramount (Lewis, 2004).

In view of the importance of internship in higher education (Lam \& Ching, 2006; Rothman, 2007; Walo, 2001), internship has become part of the curriculum of higher education (Beggs et al., 2008; Domask, 2007) because the educational institutions normally do not have the facilities hence it is an avenue through which the industry complements what is taught in the classroom (Rothman, 2007). But how can one ascertain that the goals of student internship are accomplished when the internship is not guided with clear (written) curriculum materials. A recent study on the current situation regarding internship in the hospitality management sector in Ghana's polytechnics revealed that polytechnicindustry collaboration needs to be strengthened, students fail to meet the required internship period of six months, some students fail to embark on internship at all due to limited number of placements, interns need to have experience in all sections of industry, and the need was expressed by the various stakeholders to design curriculum materials to guide student internships (Akomaning, Voogt, \& Pieters, 2011). The hospitality and tourism industry in Ghana generates tremendous economic activity, the sector's contribution to GDP was US $\$ 1.2$ billion in 2008 (Ghana Tourist Board, 2009) and it is expected to become the first foreign exchange earner by 2015. However, the sector lacks qualified staff. The improvement in student internship is an important aspect of the preparation of qualified staff for the sector and is a major concern in the curriculum reform in Ghana's polytechnics (Gervedink Nijhuis, Bakah, \& Akomaning, 2009). This study aims to contribute to an improved student internship curriculum for the hospitality management sector in Ghana's polytechnic by involvement of and collaboration among relevant stakeholders in the design of curriculum materials for internship. In this study, polytechnic teachers collaboratively designed curriculum materials to improve student internship in hospitality industry. 


\subsection{THEORETICAL UNDERPINNINGS}

\subsubsection{Design teams and collaborative curriculum design}

Design team is explained as a collaborative group working together to produce a unit of instruction or creating a product (Waddoups, Wentworth, \& Earle, 2004) which is implemented and evaluated (Handelzalts, 2009) in an educational institution programme. It implies that in the design process teachers investigate challenges in their current instructional practice, (re-)design product(s), implement the product(s) and evaluate it. In this study, curriculum materials for student internship were designed, implemented and evaluated. Collaboration in design teams, according to Handelzalts (2009) and Simmie (2007) contribute to enhanced teacher knowledge, skills and practices. Research results indicate that through the sense of security that comes from design teams and support from colleagues, there is a greater willingness to experiment, try new things and be more apt to consider continual development in curriculum reform (Hargreaves, 2003). Participation in self-managed design teams, where members have the authority to make decisions and take actions to advance goals determined by the team, may intensify members' commitment to the team and to foster collaboration among team members (Dee et al., 2006; Waddoups et al., 2004). Teacher collaboration in design teams, according to Little (1990) and Riordan (2001) denote joint work, shared responsibility and the existence of high levels of trust, respect and mutuality. Design teams' activities are most often guided by a common goal. Attributes like cooperation, collaboration, consensus and teamwork are crucial to the success of design teams which does not only result in a concrete product but also culminates in professional learning (Deketelaere \& Kelchtermans, 1996; Fullan, 2007).

Collaborative curriculum design (CCD) in design teams is one such initiative where teachers get into teams to carry out activities that lead to improvement in student learning (Havnes, 2009) and teacher professional development through increasing levels of participation within a team are the key to how learning occurs (Blackwell, 2003). Collaboration in curriculum design can potentially lead to several possible learning gains for teachers: content knowledge in a target domain (Kolodner et al., 2003; Rock \& Wilson, 2005; Voogt et al., 2011; Westbroek et al., submitted); general process and collaboration skills (Guskey, 2000; Kolodner, et al., 2003). CCD in design teams was used during this research to prepare curriculum materials for the student internship programme for hospitality 
management students. This approach promotes collaborative planning incorporating the interests of student, teacher and industry (Lewis, 2004).

The assumption underlying this study is that with the support of management, CCD contributes to curriculum improvement and for that matter improvement of student internship and student learning. In order to ensure successful improvement of the curriculum, all key stakeholders must be involved (Van den Akker, 2003). Scholarship on teacher teams indicates that change is more likely to be effective and enduring when those responsible for its implementation are included in a shared decision-making process (Scribner et al., 2007). The quality of working relationships among teachers is strongly related to implementation (Fullan, 2007). The crux of successful implementation of an educational programme should not lose sight of the context of the school. In this regard Blokhuis and Nijhof (2008) point to the industry and the role of the internship supervisor.

\subsubsection{Prerequisites for implementation of renewed internship}

Internships have a long and noteworthy history in higher education (Beggs et al., 2008). Internship provides the opportunity and the learning scenario for students to experience, first hand, professional practice activities which directly relate to the application of knowledge. Bakar, Harun, Yusof, and Tahir (2011) consider internship as an opportunity to integrate career related experience into an education programme by participating in planned and supervised work. It is a temporary position which emphasises the on-the-job training, usually for a fixed period of time before graduation. According to Clark and Whitelegg (1998), internship fosters "learning by doing", which in its turn reinforces the understanding of complex concepts and the development of complex skills.

Billett (2001) contends that the manner in which internship is organised can be understood in terms of how the workplace support or inhibit individuals' engagement in work activities and access to both the direct and indirect guidance. Hence an internship which is carried out successfully is dependent on the need to conceptualise more clearly as an authentic workplace learning environment (Blokhuis \& Nijhof, 2008) through which industry's contributions can be best organised to assist the learning required of the intern (Billett, 2006). In acknowledging the crucial role internship plays in individual's initial learning and further development of vocational knowledge and skills throughout the individual's working life, Billett (2006) argues that there is a critical need for 
internship curriculum so as to ensure that the intended objectives for embarking on an industrial experience are achieved. In firming up this position, Hasbullah and Sulaiman (2002) assert that students' competencies improved remarkably through the use of curriculum materials for student internship after their industrial experience. The researchers conclude students were prepared to enter into the world of work with confidence and ready to cooperate with employees having accomplished a guided internship. Therefore, the use of curriculum materials specifying what to be learnt and who is responsible for what could create a better platform for internship to be better organised (Ko, 2008).

A well organised hospitality and tourism academic programme turns out graduates with high quality expertise to meet the needs of the industry (Goeldner \& Ritchie, 2006; Harris \& Zhao, 2004). To accomplish this, there has always been significant focus placed on students gaining practical experience outside of the classroom learning environment (Szambowski et al., 2002). These types of experiences often take place in the form of internship.

An internship is an excellent opportunity to acquire improved attitudes, knowledge and skills necessary in today's workplace (Busby, 2003). Internship is very unique experience for both student and industry that can yield significant benefits when employers view their role as mentors, taking advantage of teaching opportunities as they arise in the various sections students are made to serve (Crossley et al., 2007; Rothman, 2007). In addition, internships afford student training under both academic and practitioner supervision (Beggs et al., 2008). This supervision allows students to gain interpersonal skills with industry workers (Thiel \& Hartley, 1997). However, in order to ensure that the internship experience meets the needs of the industry, teacher and student, it is important to ensure that there are curriculum materials specifying their roles in internship.

Articulating the responsibilities of interns and internship supervisors (educators and industry-based) prior to the internship is a key element in a successful internship (Beggs et al., 2006; Rothman, 2007). In addition to articulating responsibilities, it is important for educators to help students understand the types of experiences that they should be seeking in an internship (Beggs et al., 2006). There is a need for this type of knowledge in order to better understand the internship experience to prepare students for a future career; to provide educators with information useful for curriculum design and development; and to assist 
internship supervisors and agencies with information to have a better understanding of the student needs and interests (Leslie \& Richardson, 2000; Petrillose \& Montgomery, 1998). Walo (2001) specifies interns' assessment to be carried out by both the educational institution's academic supervisor and industry supervisor in order to have comparable assessments.

\subsection{CONTEXT OF THE STUDY}

Polytechnics in Ghana are part of the tertiary education system. Unlike the university, polytechnic education is practically oriented and career focused preparing its students to occupy the middle level manpower as supervisors and managers equipped with competencies that make them easily employable (set-up their own businesses) in the various sectors of the Ghanaian economy. However, the links between polytechnics and industry is episodic (Effah, 2005). In Ghana, industries are under no obligation to draw up a training programme for potential interns. Moreover, there is no policy on industries being compelled to give feedback on interns to polytechnics which counter to the dictates of structured internships (McManus \& Feinstein, 2008). Internship activities in the polytechnics are under the auspices of the Industrial Liaison Unit (ILU) in each polytechnic. The nature of the internship is described as unstructured by Effah (2005).

The department of Hotel Catering and Institutional Management (HCIM) is one of the departments whose responsibility is to train students to assume managerial or supervisory roles in the hospitality industry. The HCIM programme is a three-year tertiary programme. Entrants into the programme are predominantly those who have successfully completed the Home Economics programme at the senior secondary school. Successful students graduate with a Higher National Diploma (HND) certificate in hospitality management. In order to adequately prepare students for the industry, internship is an integral component of the HCIM programme. Internships are carried out in two sessions throughout the three-year programme. Each session spans a period of three months at the end of each academic year. So, in all students are supposed to make at least six months throughout the entire study period of three years. These internship periods are supposed to be supervised by both polytechnic educators and industry representatives. 
This study took place in the Department of HCIM in Tamale Polytechnic. Tamale Polytechnic was established in 1950 as a trade school. It was converted into a technical institute in 1963 and in 1993 it was upgraded to the level of a tertiary institution (Tamale Polytechnic, 2007).

\subsection{FOCUS OF THE STUDY}

This study sought to determine the effect of CCD in design teams on improved curriculum materials for the renewed student internship. The key research question framing this study was Does collaborative curriculum design in design teams contribute to an improved curriculum for student internship?

The following sub-questions were formulated for the study:

1. How did teachers perceive working in design teams to improve the student internship curriculum?

2. How satisfied were the stakeholders; polytechnic, teachers, students, and industry, with the realisation of the renewed student internship?

3. Has the use of the curriculum materials, designed according to the guidelines, improved students' internship practices and competencies?

\subsection{INTERVENTION: CCD IN DESIGN TEAMS}

An overview of the intervention is presented in Table 3.1. Workshops were organised for stakeholders on the challenges identified in the context and needs study (Akomaning et al., 2011) and possible solutions to the challenges from stakeholders with the view of improving student internship. After that two teams of teachers were formed to collaboratively design curriculum materials for student internship. Each team consisted of four teachers. One team developed material for food production and food and beverage and the other material for accommodation and front office operation. The design of the curriculum materials took about eight weeks. 
Table 3.1 Overview of the intervention

\begin{tabular}{|c|c|c|c|}
\hline $\begin{array}{l}\text { Date/ } \\
\text { period } \\
\text { May-Oct } \\
\text { ‘09 }\end{array}$ & Activity & Purpose & $\begin{array}{l}\text { Stakeholders } \\
\text { involved }\end{array}$ \\
\hline May & $\begin{array}{l}\text { Presenting outcomes of } \\
\text { context and needs analysis }\end{array}$ & $\begin{array}{l}\text { Inform and accept outcomes; } \\
\text { Make contributions for } \\
\text { subsequent internships }\end{array}$ & $\begin{array}{l}\text { HOD, } \\
\text { (assistant) ILO, } \\
\text { students, } \\
\text { industry } \\
\text { representatives, } \\
\text { teachers }\end{array}$ \\
\hline May & $\begin{array}{l}\text { Workshop on Curriculum } \\
\text { design \& design teams }\end{array}$ & $\begin{array}{l}\text { Basic design principles in } \\
\text { curriculum design \& formation } \\
\text { of design teams }\end{array}$ & HOD, teachers \\
\hline June & $\begin{array}{l}\text { Collaborative design of } \\
\text { curriculum materials, taking } \\
\text { on board suggestions from } \\
\text { industry and students }\end{array}$ & $\begin{array}{l}\text { To prepare curriculum } \\
\text { materials to improve student } \\
\text { internship }\end{array}$ & Design teams \\
\hline June & $\begin{array}{l}\text { Compilation of documents } \\
\text { into a draft curriculum } \\
\text { materials }\end{array}$ & $\begin{array}{l}\text { Copies made for stakeholders } \\
\text { to get further input }\end{array}$ & $\begin{array}{l}\text { Teachers, } \\
\text { students, } \\
\text { industry } \\
\text { representatives }\end{array}$ \\
\hline July & $\begin{array}{l}\text { Final curriculum materials (a } \\
\text { seven-page) }\end{array}$ & $\begin{array}{l}\text { Distribution to stakeholders as } \\
\text { a working document for } \\
\text { student internship }\end{array}$ & $\begin{array}{l}\text { Teachers, ILO, } \\
\text { students, } \\
\text { industry }\end{array}$ \\
\hline July-Sept & Students on internship & $\begin{array}{l}\text { Industrial training using } \\
\text { curriculum materials to } \\
\text { improve student competencies }\end{array}$ & $\begin{array}{l}\text { Students, } \\
\text { industry }\end{array}$ \\
\hline
\end{tabular}

The curriculum materials had the following components: objectives of student internship, content description of the four core areas of the hospitality industry, practical activities the students had to conduct during student internship, job rotation during internship, assessment and student supervision from teachers and industry. The main guidelines of designing student internship curriculum, discussed in the introduction, were applied in the design of the curriculum: the length of time of internship, need for job rotation, support in achieving the expected objectives set by interns, installing industry supervision, and effective cooperation of supervisors with interns. Copies of the final document were made and distributed to all stakeholders. During student internship the industrial liaison officer (ILO) and teachers (July-September) were expected to supervise the students, but in practice this did not happen. 


\subsection{METHODS}

\subsubsection{Design of the study}

The study is a single-case design (Yin, 2003) in the context of the polytechnic and the case is Department of HCIM with teachers, students and industry as units of analysis. The study aimed at exploring the effect of teachers' collaborative design of curriculum materials on student internship which was implemented during 2009 student internship in hospitals and hotels in Ghana.

\subsubsection{Participants}

Eight teachers participated in two design teams. Three of them had previous experience in curriculum development. The Industrial Liaison Officer (ILO) participated because he is kingpin regarding the organisation of internships and in the link between the polytechnic and industry. Fifteen industry representatives comprising 11 hotels and four hospitals were involved. A total of 66 first $(N=41)$ and second $(N=25)$ year students took part in the workshops at the start of the intervention. Fifty-three out of the 66 participated in the data collection at the end of the intervention (number of students available as at the time of administering the questionnaire). Of those 53, 23 students participated in the 2009 internship (referred to as trained) and 30 students did not participate in the internship (referred to as untrained).

\subsubsection{Research instruments}

Table 3.2 depicts an overview of research instruments and constructs measured. The instruments to participants were similar (see Appendices B1, B2, B4, B5, B6, B7 and B8). 
Table 3.2

Overview of research instruments and constructs addressed

\begin{tabular}{|c|c|c|c|c|c|}
\hline Period & Instrument & $\begin{array}{l}\text { No. of } \\
\text { Items }\end{array}$ & Construct & Reliability & $\begin{array}{l}\text { Research } \\
\text { question }\end{array}$ \\
\hline \multirow[t]{2}{*}{ Pre } & $\begin{array}{l}1^{\text {st }} \text { student } \\
\text { questionnaire }\end{array}$ & 2 & $\begin{array}{l}\text { Placement of } 2009 \\
\text { internship }\end{array}$ & N/A & N/A \\
\hline & $\begin{array}{l}\text { Recorded design } \\
\text { team meetings }\end{array}$ & 4 & $\begin{array}{l}\text { Cordiality, friendliness, } \\
\text { frankness, brainstorming }\end{array}$ & N/A & 1 \\
\hline Pre/Post & $\begin{array}{l}1^{\text {st }} \& 2^{\text {nd }} \text { Teacher } \\
\text { questionnaires }\end{array}$ & 8 & $\begin{array}{l}\text { Perceptions: professional } \\
\text { commitment }\end{array}$ & $.79 / .87$ & 1 \\
\hline Pre/Post & " & 4 & -interdependence & $.80 / .61$ & 1 \\
\hline Pre/Post & " & 4 & $\begin{array}{l}\text {-healthy interpersonal } \\
\text { relationship }\end{array}$ & $.70 / .87$ & 1 \\
\hline Pre/Post & “ & 4 & -mutual respect & $.67 / .86$ & 1 \\
\hline Pre/Post & “ & 2 & $\begin{array}{l}\text {-participative decision } \\
\text { making }\end{array}$ & $.72 / .72$ & 1 \\
\hline Post & $\begin{array}{l}2^{\text {nd }} \text { teacher/ } \\
\text { student/industry }\end{array}$ & $10 / 10 / 7$ & Satisfaction of involvement & $.89 / .80 / .62$ & 2 \\
\hline Post & $2^{\text {nd }}$ teacher & 5 & Assessment of internship & .71 & 2 \\
\hline Post & $2^{\text {nd }}$ student & 4 & Assessment of industry & .96 & 2 \\
\hline Post & “ & 3 & Food preparation methods & .65 & 3 \\
\hline Post & “ & 5 & Food preparation & .84 & 3 \\
\hline Post & “ & 5 & Skill in restaurant service & .68 & 3 \\
\hline Post & “ & 4 & Customer care & .78 & 3 \\
\hline Post & “ & 9 & $\begin{array}{l}\text { Skills in front office } \\
\text { operations }\end{array}$ & .87 & 3 \\
\hline Post & “ & 2 & $\begin{array}{l}\text { Front office operations } \\
\text { records }\end{array}$ & .68 & 3 \\
\hline Post & “ & 4 & Skills in Accommodation & .72 & 3 \\
\hline Post & " & 4 & $\begin{array}{l}\text { Accommodation } \\
\text { operations }\end{array}$ & .86 & 3 \\
\hline Post & “ & 2 & $\begin{array}{l}\text { Assessment of curriculum } \\
\text { materials }\end{array}$ & N/A & 3 \\
\hline \multirow[t]{3}{*}{ Post } & ILO interview & 5 & $\begin{array}{l}\text { Role, challenges, } \\
\text { suggestions }\end{array}$ & N/A & 2 \\
\hline & Checklist & 3 & $\begin{array}{l}\text { Behaviour, industrial } \\
\text { training, environment, }\end{array}$ & N/A & 2 \\
\hline & " & 6 & $\begin{array}{l}\text { departments served, } \\
\text { number of participants, } \\
\text { supervision, duration, } \\
\text { objectives: expected and } \\
\text { achieved }\end{array}$ & N/A & 3 \\
\hline
\end{tabular}

Note: N/A presents 'not applicable'. 
Student instruments: Two sets of questionnaires were administered to students. The first was administered immediately after the meetings in May which highlighted on the year group, placement of 2009 internship. The second questionnaire, similar to the first, was administered immediately after internship five months later. The questionnaires consisted predominantly of close-ended statements and few open-ended questions. The former comprised question items on a five-point Likert scale using responses graded: 1 strongly disagree to 5 strongly agree to determine the level of agreement to statements. These statements centred on stakeholders' participation in internship, students' assessment of industry contribution during internship and assessment of student competencies after internship. The open-ended questions centred on year group, gender, place of first and second internships and duration. Others were sections of industry where the student was trained, and a brief description of competencies acquired in the recent internship (see Appendices B2 and B6).

Teachers' questionnaires: Two sets of questionnaires were administered to teachers. The first was immediately after the workshops in May. The rationale was to elicit background information on teacher experience in curriculum activities and their competencies in this regard. These were the open-ended questions. The closeended items were in a five-point Likert scale using responses ranging from 1 to 5 representing strongly disagree to strongly agree respectively which addressed teacher perceptions, satisfaction of involvement and assessment of internship (see Table 3.2). The second batch of the questionnaire was administered to teachers after students had returned from internship and was similar to the first one with some additions about support for design teams, and satisfaction involvement of stakeholders. Open-ended questions included: institutional support to design teams, role played by teachers during the internship, problems encountered, assessment criteria, type of training students experienced, competencies acquired during design teams sessions, and change of teacher perceptions about design teams (see Appendices B1 and B8).

Recorded sessions: Design team sessions were recorded and analysed to support data about teacher perceptions on CCD.

ILO's interview: The ILO was interviewed after the 2009 internship concerning his role and contribution to the internship. He also answered questions on role 
expectations of other polytechnic groupings regarding organisation of internship, challenges facing the unit and suggestions for improvement (see B7).

Questionnaire to industry personnel: Questionnaire to hotel industry and hospitals was mainly close-ended (a five-point Likert scale with responses ranging from 1 to 5 representing strongly disagree and strongly agree respectively) with a few openended questions. The close-ended focused on formalisation of links between polytechnic and industry, active involvement of teachers in student internship, teacher and industry supervision, students are made to write reports which form part of their assessment and industry reports on students' performance to the polytechnic. The open-ended questions centred on name and type of organisation, position of respondent, description of training given to students, departments served by student(s) and the impact of curriculum materials on student internship. Administration of this instrument was done while students were on internship. Retrieval of instrument was carried out by interns after internship and submitted to the researcher when they returned to the polytechnic (see Appendix B5).

Checklist and researcher's logbook: The checklist was used to collect data during students' visits by the researcher in organisations. The purpose was to know at first-hand the state of interns and to interact with personnel of organisations concerning interns' general behaviour. Student assigned role, industry training, working environment, industry supervision, teacher supervision, competencies expected and competencies achieved were the indices being investigated. In all 15 interns were visited in 15 organisations. The researcher also kept a logbook during the visits to the hospitality industry (see Appendix B4).

\subsubsection{Data analysis}

Data were analysed qualitatively and quantitatively. Data from questionnaires were analysed using SPSS. Non-parametric tests were used to determine differences in teacher perceptions (Wilcoxon) before and after intervention and differences between competencies of students trained and untrained (MannWhitney U). The Kruskal-Wallis test and descriptives were used to determine differences expressed in views by stakeholders regarding their level of participation in student internship. ILO's responses in the interview were audio taped, transcribed and major themes identified. Data from checklist was analysed qualitatively by use of percentages to identify the major themes and to present them accordingly (Miles \& Huberman, 1994). 


\subsection{RESULTS}

\subsubsection{Perceptions about CCD in design teams}

Table 3.3 captures the before- (before joining design teams) and after- (after internship) teacher perceptions about how they collaborated in the design of the curriculum materials for internship (Appendix B9). Generally, teachers admitted that professional commitment, healthy interpersonal relationship, mutual respect and participative decision making were virtues that were promoted in design teams' activities. Teachers traded ideas and there was division of labour during preparation of the curriculum materials. The Wilcoxon test revealed that teachers' perceptions about CCD were very positive, and did not change significantly over the period of the study.

Table 3.3 Teacher perceptions about CCD in design teams before and after internship $(N=8)$

\begin{tabular}{|lcccc|}
\hline Perception & Design teams & Mean rank & z-value & Sig. \\
\hline Professional commitment & Pre-test & 4.3 & -.493 & .31 \\
& Post-test & 4.8 & & \\
\hline Interdependence & Pre-test & 3.0 & -1.263 & .11 \\
& Post-test & 5.4 & & \\
\hline Healthy interpersonal & Pre-test & 4.0 & -1.186 & .12 \\
relationship & Post-test & 2.5 & & \\
\hline Mutual respect & Pre-test & 3.4 & -.632 & .26 \\
& Post-test & 3.8 & & \\
\hline Participative decision making & Pre-test & 3.6 & -.086 & .47 \\
& Post-test & 4.5 & & \\
\hline
\end{tabular}

The recorded design team sessions before and during the formation of design teams suggest that of cordiality, friendliness, frankness and brainstorming of ideas and concepts regarding the design of the curriculum materials. Professional commitment constitutes statements like doing better quality work in design teams, work is better organised in design teams and content knowledge of materials accepted on consensus. In curriculum development, ensuring better quality work, doing better organisation and content knowledge being generally accepted are key to CCD in design teams.

Healthy interpersonal relationship in the work of design teams was perceived by teachers with a marginal decrease in the means (before-mean=4.0; after-mean=2.5) $[\mathrm{z}=-1.186, p=0.14]$. It is of interest to note that teachers were consistently opposed 
to the statements that when they worked in design teams, they found it hard expressing their thoughts. In other words, teachers were able to express their views in design teams because of healthy interpersonal relationship.

In sum, teachers were positive about the CCD in design teams culminating in their perceptual increases in professional commitment, interdependence, mutual respect and participative decision making. They also did not feel intimidated expressing their views in design team sessions. The marginal change in teacher perceptions could be partly due to the brevity of their activities in design teams. The recorded design team sessions suggested that the design team activities were platforms for sharing experiences with colleagues in an atmosphere of collegiality. With the support from industry and students, design teams' activities led to the design of the curriculum materials which were used in the 2009 student internship.

\subsubsection{Perspectives of stakeholders about renewed student internship}

Table 3.4 points out the role of stakeholders in renewed student internship from the perspectives of teachers, students and industry; renewed in the sense that now there are curriculum materials to guide student internship. In connection with polytechnic having formal agreement with organisations in Ghana the students were hesitant $(M=3.2 ; S D=1.47)$, teachers opposed to the statement $(M=2.6$; $\mathrm{SD}=1.06)$ and industry's view suggested disagreement $(\mathrm{M}=1.6 ; \mathrm{SD}=0.90)$. KruskalWallis test showed an overall significant difference between students and industry $\left(X^{2}=9.24, p=0.010\right)$.

All stakeholders also tend to disagree with the statements polytechnic makes prior contacts with organisations before students go for internship (means between 2.4 and 2.8) and polytechnic looks for organisations for students to practise (mean between 1.7 and 1.8). Regarding polytechnic involvement in internship, one of the teachers indicated, 'The polytechnic is supposed to send staff to supervise students. The industrial liaison officer is also supposed to be the coordinator'. Three other teachers revealed that the polytechnic issues out introductory letters and assessment forms for students who express interest in internship. Three teachers indicated nothing was done by the polytechnic toward student internship. 
Table 3.4 Views of stakeholders regarding renewed student internship

\begin{tabular}{|c|c|c|c|c|c|c|c|c|}
\hline \multirow[b]{2}{*}{ Statement } & \multicolumn{2}{|c|}{$\begin{array}{l}\text { Students } \\
(N=23)\end{array}$} & \multicolumn{2}{|c|}{$\begin{array}{l}\text { Teachers } \\
\qquad(N=8)\end{array}$} & \multicolumn{2}{|c|}{$\begin{array}{l}\text { Industry } \\
(N=12)\end{array}$} & \multirow[b]{2}{*}{$X^{2}$} & \multirow[b]{2}{*}{ Sig. } \\
\hline & Mean & SD & Mean & $S D$ & Mean & $S D$ & & \\
\hline $\begin{array}{l}\text { Formal agreement between } \\
\text { polytechnic and organisations }\end{array}$ & 3.2 & 1.47 & 2.6 & 1.06 & 1.6 & .90 & 9.24 & $.010^{*}$ \\
\hline $\begin{array}{l}\text { Polytechnic makes prior contacts } \\
\text { with organisations before students } \\
\text { go for internship. }\end{array}$ & 2.4 & 1.53 & 2.8 & 1.17 & 2.4 & 1.44 & .924 & .630 \\
\hline $\begin{array}{l}\text { Polytechnic looks for organisations } \\
\text { for students to practise. }\end{array}$ & 1.8 & 1.15 & 1.8 & .89 & 1.7 & .65 & .045 & .978 \\
\hline $\begin{array}{l}\text { Active participation of HCIM } \\
\text { teachers in internship }\end{array}$ & 2.3 & 1.06 & 2.5 & 1.31 & 1.8 & .87 & 2.82 & .244 \\
\hline $\begin{array}{l}\text { Supervision of students' internship } \\
\text { work }\end{array}$ & 2.1 & 1.39 & 1.8 & 1.39 & 1.4 & .52 & 1.647 & .439 \\
\hline $\begin{array}{l}\text { Enough teacher supervision of } \\
\text { students during internship. (Not } \\
\text { applied to industry) }\end{array}$ & 1.8 & 1.09 & 1.6 & 1.06 & - & - & .126 & .722 \\
\hline $\begin{array}{l}\text { Students write reports on their } \\
\text { experience on internship. (Not } \\
\text { applied to industry) }\end{array}$ & 3.4 & 1.59 & 3.3 & 1.67 & - & - & .001 & .981 \\
\hline $\begin{array}{l}\text { Student internship reports form } \\
\text { part of students' assessment. (Not } \\
\text { applied to industry) }\end{array}$ & 2.9 & 1.33 & 1.8 & 1.39 & - & - & 5.052 & $.025^{*}$ \\
\hline $\begin{array}{l}\text { Proper supervision of students by } \\
\text { supervisors in organisations }\end{array}$ & 3.5 & 1.31 & 2.6 & 1.41 & 3.6 & 1.31 & 2.869 & .238 \\
\hline $\begin{array}{l}\text { Industry reports on the } \\
\text { performance of students to the } \\
\text { polytechnic. }\end{array}$ & 3.6 & 1.53 & 2.9 & 1.36 & 3.5 & 1.24 & 2.463 & .292 \\
\hline
\end{tabular}

Note: Rating scale: 1 , strongly disagree; 2 , disagree; 3 , neutral; 4, agree; 5 , strongly agree; SD, standard deviation; ${ }^{*} p<0.05$

All stakeholders undisputedly disagreed to the statements that teachers were involved in student internship (means between 1.8; $\mathrm{SD}=0.87$ and 2.5; $\mathrm{SD}=1.31$ ). Supervision of interns by educational institution is very crucial to successful internship, unfortunately, teachers did not supervise and the means were in the magnitude of 1.4 and 2.1. However, industry supervision of students was quite encouraging (Industry mean=3.6; Students mean=3.5; Teachers mean=2.6). The figures imply that industry's input into internship programme was quite commendable. Teachers and students were not certain regarding students writing reports during internship (Teachers mean $=3.3$; Students mean=3.4) and they tend to disagree on reports forming part of students' assessment (Teachers mean=1.8; 
Students mean=2.9). The figures suggest students were more positive than the teachers. Kruskal-Wallis test shows significant difference $\left(X^{2}=5.025, p=0.025\right)$.

The ILO was interviewed about his role in the 2009 internship, he said, "The specific role I played was writing letters to the industries for students; I did not go round to supervise or to monitor because we asked for means and they couldn't provide us". His personal observations regarding the 2009 internship were as follows: "My personal observation is that there is much work to be done especially on my part but I am limited for non availability of facilities like transport but on paper the idea is good but in practice we are not doing much..."

\subsubsection{Students' assessment of industry contribution to renewed internship}

The workplaces where students had their internship were assessed by students (Table 3.5). All the means were high (4.3 to 4.5), implying that interns were very satisfied about their internship. This finding was contrary to the findings of the needs analysis (Akomaning et al., 2011) where interns complained that industrial staff held back and were unfriendly. The use of the curriculum materials might have partly contributed to the improved internship practices because the roles of stakeholders are specified in the materials.

Table 3.5 Students' assessment of industry contribution ( $N=23)$

\begin{tabular}{llc} 
Statement & Mean & Std. Deviation \\
\hline I benefited a lot from the recent internship. & 4.4 & .79 \\
\hline Industry workers were helpful to me. & 4.3 & 1.02 \\
\hline I was taught by the industrial workers. & 4.5 & .73 \\
Learnt to work with other hospitality industry workers & 4.4 & .90
\end{tabular}

Note: Rating scale: 1 , strongly disagree; 2 , disagree; 3 , neutral; 4 , agree; 5 , strongly agree.

\subsubsection{Teachers' assessment of the renewed internship}

Table 3.6 depicts teachers' assessment of the support from the polytechnic regarding student internship. Teachers disagreed to the statements that there has been an improvement in the polytechnic support for organising student internship (mean=2.5; SD=.93). They did not differ much in their views concerning improvement in the activities of the ILU towards student internship (mean=2.8; $\mathrm{SD}=1.28$ ) and the receipt of internship letters on time by industry (mean=2.3; $\mathrm{SD}=.89$ ). In the same vein, they responded in the negative to students' 
supervision during internship by teachers and industry personnel. The means were 1.6 and 1.9 respectively.

Table 3.6 Assessment of 2009 internship by teachers $(N=8)$

\begin{tabular}{lcc} 
Statement & Mean & $\begin{array}{c}\text { Std. } \\
\text { Deviation }\end{array}$ \\
\hline $\begin{array}{l}\text { Improvement in polytechnic support for organizing } \\
\text { internships. }\end{array}$ & 2.5 & .93 \\
$\begin{array}{l}\text { Activities of ILU towards internship programme have } \\
\text { improved. }\end{array}$ & 2.8 & 1.28 \\
\hline $\begin{array}{l}\text { Internship letters to organisations are received on time. } \\
\text { Teacher supervision of students on internship has improved. }\end{array}$ & 2.3 & .89 \\
$\begin{array}{l}\text { Hospitality industry supervision of students on internship has } \\
\text { improved. }\end{array}$ & 1.9 & .74 \\
\hline
\end{tabular}

Note: Rating scale: 1, strongly disagree; 2, disagree; 3, neutral; 4, agree; 5, strongly agree.

In reaction to the question from teacher questionnaire, What specific work do you carry out during student internship? One teacher responded, "Staff are supposed to mark students' log books, advise and also learn about what is happening in industry". Another teacher indicated, "At the moment I am not obliged to do anything or carry out any specific duty during student industrial attachment". The remaining colleagues indicated they were quite inactive.

Concerning problems teachers encountered during the 2009 internship, a response given by a teacher summarises the responses of all teachers, "Actually industrial attachment is not considered seriously by the institution. The industrial liaison officer does his own thing so some students do it others don't and since we don't play any part we don't have problems".

Inferences can be drawn from the responses of teachers and ILO that because student internship was not compulsory, teachers did not supervise interns as well as personnel from the ILU. It is however reassuring that both teachers and the personnel from the ILU were not ignorant about their respective roles in internship. The unfortunate state of polytechnic demonstration of lack of professional commitment regarding student internship was blamed on the polytechnic's inability to empower the ILU financially and logistically. 


\subsubsection{Assessment of job performance by stakeholders}

Assessment of job performance of students is presented in Table 3.7. The mean difference among stakeholders was significant $\left(X^{2}=9.409, p=.009\right)$. Contrary to expectation, industry's mean was higher than teachers'. The implication may be that the latter did not take part in student supervision during internship and for that matter was not in a well-informed position to assess interns. Industry and students were quite satisfied because they were actively involved in the internship programme.

Table 3.7 Assessment of job performance

\begin{tabular}{lcccccc} 
& & \multicolumn{7}{c}{ Mean } & & & \\
Statement & Stakeholders & $N$ & Rank & Df & $X^{2}$ & Sig. \\
General satisfaction of students' & Students & 23 & 26.50 & 2 & 9.409 & $.009^{*}$ \\
job performance & Teachers & 8 & 11.44 & & & \\
& Industry & 12 & 20.42 & & &
\end{tabular}

Note: ${ }^{*} p<0.05$.

In conclusion, the involvement of polytechnic, teachers and industry regarding student internship needed to be invigorated. The link between the polytechnic and industry was not formalised and link could be described as episodic. However, industry's contribution to interns' training and students' conduct were commendable. The curriculum materials were a source of guide to both students and industry. Teachers' inactive involvement in the internship was due to the polytechnic's inability to provide for the required resources to complement the effort of industry. Students and industry personnel were satisfied with the job performance of students but teachers were not.

\subsubsection{Improved internship practices}

This section looks whether students' (self-reported) use of the curriculum materials for the 2009 internship might have influenced internship practices and the resultant improvement in competencies of students who took part in the industrial training. Firstly, the level of participation in 2009 internship (43\%) increased as compared with the previous internship (29\%). Secondly, excerpts from the checklist shows that interns were not kept in one department (as in the previous study). Generally, there was job rotation where 82 percent of the ( 9 out of 11) interns went to at least three of the four core departments in the hotel industry. However, the duration for industrial training was relatively short. 
Interns spent between 4 to 8 weeks in internship (61\% spent 8 weeks). This was an improvement on the previous year's (2008) when interns spent between 2 and 6 weeks. Moreover, interns described industry supervision as very good; employees assisted interns when in difficulty.

Table 3.8 presents how the curriculum materials assisted interns' training in industry as well as in the writing of their reports on industrial experience. Means of 4.3 and 3.2 respectively were recorded. In support of these claims, six out of 15 indicated the curriculum materials assisted them in their training and daily industrial report writing whereas nine out of 15 indicated their fears were allayed because they had a document to work with. Ten out of 15 interns fully achieved their expected objectives.

Table 3.8 Assessment of curriculum materials for internship $(N=23)$

$\begin{array}{lcc}\text { Statement } & \text { Mean } & \text { Std. Dev. } \\ \text { Curriculum materials help during internship } & 4.3 & 0.64 \\ \text { Curriculum materials help in report writing } & 3.2 & 0.65\end{array}$

Note: $\quad$ Rating scale: 1 , strongly disagree; 2 , disagree; 3 , neutral; 4, agree; 5 , strongly agree.

\subsubsection{Competencies of students}

\section{Food production}

Table 3.9 presents the self-reported competencies in food production of students who took part in internship (labelled trained) and those who did not (labelled untrained). The Mann-Whitney $U$-test shows that competencies in food production scores of first year students trained were significantly higher than those untrained for both food preparation methods $(U=57.0, p=0.0005)$ and food preparation ( $U=40.5, p=0.0003$ ). The Mann-Whitney $U$-test also shows that competencies in food preparation methods scores of the trained were significantly higher than those untrained for second year students $(U=16.5, p=0.022)$. 
Table 3.9 Competencies of students in Food Production after intervention

\begin{tabular}{|c|c|c|c|c|c|c|}
\hline $\begin{array}{l}\text { Student } \\
\text { status }\end{array}$ & $N$ & Competency & $\begin{array}{l}\text { Mean } \\
\text { Rank }\end{array}$ & $\begin{array}{c}\text { Mann- } \\
\text { Whitney } \\
U\end{array}$ & Z-value & $\begin{array}{l}\text { Sig. (one- } \\
\text { tailed) }\end{array}$ \\
\hline $\begin{array}{l}\text { HND } 1 \\
\text { Trained } \\
\text { Untrained }\end{array}$ & $\begin{array}{l}16 \\
19\end{array}$ & $\begin{array}{l}\text { Food preparation } \\
\text { methods }\end{array}$ & $\begin{array}{l}23.9 \\
13.0\end{array}$ & 57.0 & -3.192 & $0.0005^{*}$ \\
\hline $\begin{array}{l}\text { HND } 1 \\
\text { Trained } \\
\text { Untrained }\end{array}$ & $\begin{array}{l}16 \\
19\end{array}$ & Food preparation & $\begin{array}{l}25.0 \\
12.1\end{array}$ & 40.5 & -3.704 & $0.0003^{*}$ \\
\hline $\begin{array}{l}\text { HND } 2 \\
\text { Trained } \\
\text { Untrained }\end{array}$ & $\begin{array}{c}7 \\
11\end{array}$ & $\begin{array}{c}\text { Food preparation } \\
\text { methods }\end{array}$ & $\begin{array}{c}12.6 \\
7.5\end{array}$ & 16.5 & -2.022 & $0.022^{*}$ \\
\hline $\begin{array}{l}\text { HND } 2 \\
\text { Trained } \\
\text { Untrained }\end{array}$ & $\begin{array}{c}7 \\
11\end{array}$ & Food preparation & $\begin{array}{l}9.6 \\
9.5\end{array}$ & 38.0 & -.046 & 0.482 \\
\hline
\end{tabular}

Note: ${ }^{*} p<0.05$

\section{Food and beverage}

Table 3.10 shows the competencies of students in food and beverage for trained and untrained students. The competencies of trained were significantly higher than the untrained except for the HND 2 students in skills in restaurant service $(U=24.5$, $p=0.1001)$.

Table 3.10 Competencies of students in Food and Beverage after intervention

\begin{tabular}{|c|c|c|c|c|c|c|}
\hline $\begin{array}{l}\text { Student } \\
\text { status }\end{array}$ & $N$ & Competency & $\begin{array}{l}\text { Mean } \\
\text { Rank }\end{array}$ & $\begin{array}{c}\text { Mann- } \\
\text { Whitney } \\
U\end{array}$ & Z-value & $\begin{array}{l}\text { Sig. } \\
\text { (one- } \\
\text { tailed) }\end{array}$ \\
\hline $\begin{array}{l}\text { HND } 1 \\
\text { Trained } \\
\text { Untrained }\end{array}$ & $\begin{array}{l}16 \\
19\end{array}$ & $\begin{array}{l}\text { Skills in } \\
\text { restaurant service }\end{array}$ & $\begin{array}{l}22.2 \\
14.5\end{array}$ & 85.0 & -2.229 & $0.013^{*}$ \\
\hline $\begin{array}{l}\text { HND } 1 \\
\text { Trained } \\
\text { Untrained }\end{array}$ & $\begin{array}{l}16 \\
19\end{array}$ & Customer care & $\begin{array}{l}21.9 \\
14.7\end{array}$ & 90.0 & -2.092 & $0.018^{*}$ \\
\hline $\begin{array}{l}\text { HND } 2 \\
\text { Trained } \\
\text { Untrained }\end{array}$ & $\begin{array}{c}7 \\
11\end{array}$ & $\begin{array}{l}\text { Skills in } \\
\text { restaurant service }\end{array}$ & $\begin{array}{c}11.5 \\
8.2\end{array}$ & 24.5 & -1.278 & 0.1001 \\
\hline $\begin{array}{l}\text { HND } 2 \\
\text { Trained } \\
\text { Untrained }\end{array}$ & $\begin{array}{c}7 \\
11\end{array}$ & Customer care & $\begin{array}{c}12.4 \\
7.6\end{array}$ & 18.0 & -1.278 & $0.0275^{*}$ \\
\hline
\end{tabular}

Note: ${ }^{*} p<0.05$ 


\section{Front office operation}

Differences in competencies in front office operation for the untrained and trained in first year students were not significant (Table 3.11). However, their second year counterparts were significantly higher in competencies in the trained than untrained ( $U_{1}=14.0, p=0.0125 ; U_{2}=18.0, p=0.025$ ). The researcher's interactions with some hotel managers suggest that hotel operators hardly allowed interns to be at front office (reception) for fear of the novices' demonstration of unprofessional behaviour that might drive away customers and potential customers. In hotels where they were allowed, they sat there to observe and hardly actively got involved in actual operations at this department. The significant change in the learning outcomes of the second year students might be due to the fact that they might have been given more access to the operations of the reception than their first year counterparts.

Table 3.11 Competencies of students in Front Office Operation after intervention

\begin{tabular}{|c|c|c|c|c|c|c|}
\hline $\begin{array}{l}\text { Student } \\
\text { status }\end{array}$ & $N$ & Competency & $\begin{array}{l}\text { Mean } \\
\text { Rank }\end{array}$ & $\begin{array}{c}\text { Mann- } \\
\text { Whitney } \\
U\end{array}$ & Z-value & $\begin{array}{l}\text { Sig. (one- } \\
\text { tailed) }\end{array}$ \\
\hline $\begin{array}{l}\text { HND } 1 \\
\text { Trained } \\
\text { Untrained }\end{array}$ & $\begin{array}{l}16 \\
19\end{array}$ & $\begin{array}{l}\text { Skills in Front } \\
\text { Office Operations }\end{array}$ & $\begin{array}{l}20.3 \\
16.1\end{array}$ & 116.0 & -1.195 & 0.116 \\
\hline $\begin{array}{l}\text { HND } 1 \\
\text { Trained } \\
\text { Untrained }\end{array}$ & $\begin{array}{l}16 \\
19\end{array}$ & $\begin{array}{c}\text { Front Office } \\
\text { Operation records }\end{array}$ & $\begin{array}{l}19.9 \\
16.4\end{array}$ & 121.0 & -1.053 & 0.147 \\
\hline $\begin{array}{l}\text { HND } 2 \\
\text { Trained } \\
\text { Untrained }\end{array}$ & $\begin{array}{c}7 \\
11\end{array}$ & $\begin{array}{l}\text { Skills in Front } \\
\text { Office Operations }\end{array}$ & $\begin{array}{c}13.0 \\
7.3\end{array}$ & 14.0 & -2.241 & $0.0125^{*}$ \\
\hline $\begin{array}{l}\text { HND } 2 \\
\text { Trained } \\
\text { Untrained }\end{array}$ & $\begin{array}{c}7 \\
11\end{array}$ & $\begin{array}{c}\text { Front Office } \\
\text { Operation records }\end{array}$ & $\begin{array}{c}12.4 \\
7.6\end{array}$ & 18.0 & -1.956 & $0.025^{*}$ \\
\hline
\end{tabular}

Note: ${ }^{*} p<0.05$.

\section{Accommodation operation}

The competencies of students in accommodation operation are presented in Table 3.12. Of those trained, the mean scores on competencies were significantly higher than untrained. Nonetheless, the mean scores competencies did not significantly differ for the trained and untrained second year students skills in accommodation $(U=28.5, p=0.181)$. 
Table 3.12 Competencies of students in Accommodation Operation after intervention

\begin{tabular}{|c|c|c|c|c|c|c|}
\hline $\begin{array}{l}\text { Student } \\
\text { status }\end{array}$ & $N$ & Competency & $\begin{array}{l}\text { Mean } \\
\text { Rank }\end{array}$ & $\begin{array}{c}\text { Mann- } \\
\text { Whitney } U\end{array}$ & Z-value & $\begin{array}{l}\text { Sig. (one- } \\
\text { tailed) }\end{array}$ \\
\hline $\begin{array}{l}\text { HND } 1 \\
\text { Trained } \\
\text { Untrained }\end{array}$ & $\begin{array}{l}16 \\
19\end{array}$ & $\begin{array}{c}\text { Skills in } \\
\text { Accommodation }\end{array}$ & $\begin{array}{l}21.8 \\
14.8\end{array}$ & 91.0 & -2.056 & $0.020^{*}$ \\
\hline $\begin{array}{l}\text { HND } 1 \\
\text { Trained } \\
\text { Untrained }\end{array}$ & $\begin{array}{l}16 \\
19\end{array}$ & $\begin{array}{c}\text { Accommodation } \\
\text { Operations }\end{array}$ & $\begin{array}{l}23.6 \\
13.3\end{array}$ & 62.5 & -2.991 & $0.002^{*}$ \\
\hline $\begin{array}{l}\text { HND } 2 \\
\text { Trained } \\
\text { Untrained }\end{array}$ & $\begin{array}{c}7 \\
11\end{array}$ & $\begin{array}{c}\text { Skills in } \\
\text { Accommodation }\end{array}$ & $\begin{array}{l}10.9 \\
8.6\end{array}$ & 28.5 & -.913 & 0.181 \\
\hline $\begin{array}{l}\text { HND } 2 \\
\text { Trained } \\
\text { Untrained }\end{array}$ & $\begin{array}{c}7 \\
11\end{array}$ & $\begin{array}{l}\text { Accommodation } \\
\text { Operations }\end{array}$ & $\begin{array}{c}12.3 \\
7.7\end{array}$ & 19.0 & -1.828 & $0.034^{*}$ \\
\hline
\end{tabular}

Note: ${ }^{*} p<0.05$.

\subsubsection{Description of competencies acquired}

Students were asked to describe their industrial experience during internship. These were the outcomes: the highest competency acquired was preparation of local and international dishes (26\%) which was closely followed by teamwork/communication skill (17\%). Appropriate use of kitchen equipment, appropriate use of housekeeping equipment/preparation of room for guests and serving customers at restaurant had percentage ratings of 14, 12 and 9 respectively. As compare to the previous study on student internship (Akomaning et al., 2011), these outcomes were indicative of improvement on industry commitment to student internship.

In conclusion, there were some considerable improvements in internship practices. The internship was perceived by the interns to be beneficial and the acquisition of competencies in the four main domains of the hospitality industry by interns was significant. The first year students improved remarkably in their competencies in food and beverage and accommodation operation whereas the second year students in front office operation. Unlike other departments in the hospitality industry, the most restrictive department to interns, particularly the first year students, is the front office, because industry personnel are selective when it comes to assigning interns to this department. This might have accounted for the marked improvement in the competencies of second year students. 


\subsection{CONCLUSION AND DISCUSSION}

This study has examined how design teams having received inputs from students and industry representatives collaboratively designed curriculum materials to improve student internship in the Department of HCIM at Tamale Polytechnic. Two design teams each consisting of four teachers was constituted to collaboratively design curriculum materials bordering on food production, food and beverage service, accommodation and front office operation - the four core domains of the hospitality management programme. The teachers having collaborated over a period of eight weeks were positive about the CCD in design teams which resulted in marginal improvement in their collaborative skills as expressed in professional commitment, interdependence, mutual respect, health interpersonal relationship and participative decision making. The study also unearthed that involvement of polytechnic, teachers and industry regarding student internship needed to be invigorated. The link between the polytechnic and industry was not formalised and link could be described as weak. However, industry's contribution to interns' training and interns' conduct during the 2009 internship were commendable. The curriculum materials were a source of guide to both students and industry. Teachers' inactive involvement in the internship was due to the polytechnic's inability to provide for the required resources to complement the effort of industry. Students and industry personnel were satisfied with the job performance of students but not teachers. There were also some considerable improvements in internship practices. The first year students improved considerably in their competencies in food and beverage service and accommodation operation whereas the second year students in front office operation. Unlike other departments in the hospitality industry, the most restrictive department to interns, particularly the first year students, is the front office, because industry personnel are selective when it comes to assigning interns to this department. This might have accounted for the marked improvement in the competencies of second year students.

With the support from polytechnic administration as well as the support from industry and students, design teams' activities led to the design of the improved curriculum materials which were used in the 2009 student internship programme hitherto there were no such guide. Teachers were of the opinion that CCD in design team creates a platform for sharing experiences with colleagues in an atmosphere of collegiality which confirms other studies where CCD in design teams with the support could promote teacher learning and collaborative skills of teachers 
(Guskey, 2000; Handelzalts, 2009; Simmie, 2007). The marginal change in teacher perceptions could be partly due to the brevity of their activities in design teams.

Teachers, students and industry personnel's views on the polytechnic support for student internship was very minimal (provision of introductory letter and assessment form to students willing to enrol in internship), and polytechnicindustry relationship needed to be strengthened as found in Effah (2005). Teacher supervision of students during internship was absent which runs counter to the other studies (Beggs et al., 2008; Rothman, 2007; Walo, 2001) but industry contribution on the whole was commendable. Students and industry personnel were positive toward industry supervision which was partly attributable to the use of the curriculum materials (Petrillose \& Montgomery, 1998).

Students' assessment of industry's contribution to interns' (students) training was very encouraging. Interns were given the opportunity to serve in different sections of the industry, industry workers were friendly and prepared to assist in the training of interns. These indices of successful internships as a result of guidance (stakeholders roles specified in curriculum materials) are confirmation found in Crossley et al., (2007) and Beggs et al., (2008). The self-assessed competencies of students who embarked on internship (trained) were higher than those who did not (untrained). Moreover, trained students and industry were quite satisfied about their activities during internship. Paradoxically, industry personnel were satisfied with interns' job performance during internship than their teachers.

Guided internship is very paramount, especially in the polytechnic education whose mandate is to equip its students with hands-on experience where internship is not a peripheral programme but core. The introduction of CCD in design teams, a bottom-up approach to curriculum development is a new concept in the Ghanaian Polytechnic but holds great promise in bringing about some fundamental changes that could promote the content knowledge as well as the collaborative skills of teachers and eventually assert the polytechnic's position as a tertiary institution where curricula would not be imposed by an external body (Van den Akker, 2003). The tremendous contribution of tourism and hospitality industry to the world's economy should encourage the institutions of higher learning to encourage $\mathrm{CCD}$ in design teams so as design appropriate curriculum that would serve the interest of all stakeholders. 


\title{
CHAPTER 4 \\ Towards a renewed student internship through collaborative design of curriculum materials ${ }^{3}$
}

\begin{abstract}
Polytechnics are supposed to place premium on student internship so as to better prepare their products to fit the contemporary labour market. This study examines a renewed student internship programme undertaken through collaborative design of curriculum materials. The Department of Hotel Catering and Institutional Management (HCIM), Takoradi Polytechnic in Ghana is the focus and background for the study. Teachers in the department have designed curriculum materials which, were first used for the 2010 student internship. The general perceptions of stakeholders suggest there have been improvements in internship practices and are generally satisfied with the competencies student have gained.
\end{abstract}

\subsection{INTRODUCTION}

The service encounter nature of hospitality businesses requires that their success is largely dependent on intern/employee competencies as key determinants of service quality, customer satisfaction, and loyalty (Kusluvan \& Kusluvan, 2000). Internship as part of a formal education programme is an educational activity intended for students to acquire such competencies needed to obtain the required qualification at the end of their course. In order to better provide quality internship experiences, it is vital that internship stakeholders, particularly industry and students, have comparable perceptions and expectations of the internship experience.

3 Akomaning, E., Voogt, J.M., \& Pieters, J.M. (Submitted). Towards a renewed student internship through collaborative curriculum design of curriculum materials. Journal of Hospitality, Leisure, Sport \& Tourism Education. 
A recent study by Akomaning, Voogt and Pieters (2011) on the organisation of internship in Ghanaian Polytechnics discloses the following: an episodic relationship between polytechnics and industries, lack of job rotation, lack of supervision of interns by teachers and industry-based supervisors as well as the need for improvement in assigned work and student competencies. Other disclosures hint on students' failure to meet the mandatory internship period of six months, the need for industry workers to cooperate with interns and the need for curriculum materials to be designed to streamline student internships. This study focuses on how these needs are addressed. With the exception of the search for placement and duration for internship whose improvement could be attributable to improvement in the relationship between the polytechnic and industry, the remainder could be due to the use of the designed curriculum materials. This study has sought to gravitate from hitherto unstructured internship (Effah, 2005) to structured internship (McManus \& Feinstein, 2008), which is guided by curriculum materials specifying the distinctive roles of stakeholders.

School-industry relationship has far-reaching impact on student internship. The success of an internship depends on the relationship between industry, school and student (Clark, 2003). As indicated by Kliknaite (2009), a close relationship gives rise to joint interest, ambition and purpose towards a shared vision in any well organised internship. The duration for an internship is also of key importance. How long an internship takes is dependent on its objectives (Busby \& Gibson, 2010), nature and arrangements for the industrial training (Divine, Linrud, Miller, \& Wilson, 2007). A six-month period for internship agrees with academic institutions around the globe (Mihail, 2006). Again, obtaining an internship can be a difficult and stressful prospect. One philosophy is to allow students to engage in self-search when it comes to securing an internship. The risk involved in this option could be potential student failure to enroll (Ayers, 2007). However, Divine et al. (2007) argue that self-search option has the advantage of students obtaining firsthand knowledge about the labour market which becomes a source of information for future employment. In order to address this need this study adopts collaborative curriculum design (CCD) in design teams as a strategy to collaboratively design curriculum materials to improve student internship.

CCD is a bottom-up approach to curriculum improvement where a group of teachers, teaching the same subjects or related subjects, work together on a regular basis with the ultimate aim/goal of (re)designing and implementing (a 
part of) their common curriculum (Handelzalts, 2009). The underlying assumption for adopting the concept of CCD for this study is that when teachers, who play very crucial roles when it comes to curriculum interpretation and implementation, are involved in curriculum design, they could be in a better position to incorporate materials that are relevant and practical for all stakeholders involved (students, teachers and industry).

Thus, this study examines the implementation and outcomes of the curriculum materials for student internship collaboratively designed by the design teams with input from students and industry as implemented in the 2010 student internship. The study seeks to improve student internship through CCD and implementation. The supposition underlying the study is that CCD could lead to quality products culminating in practical use of products, smooth implementation and effective organisation of student internship.

\subsection{THEORETICAL UNDERPINNINGS}

\subsubsection{Ensuring quality curriculum materials during collaborative design}

The quality of educational programmes in terms of their influence is, according to Kessels and Plomp (1999), to a large extent, determined by "consistency" of the curriculum. The researchers refer to the logic sequence between the various components of the curriculum as internal consistency. Internal consistency is reached through a "systematic approach" (Kessels \& Plomp, 1999). It implies the systematic design sequence of orientation, design, development, and evaluation. Denton, Kleist, and Surendra (2005) assert that the quality of curriculum could be addressed by eliminating duplication or overlap of topics.

External consistency, on the other hand, refers to the coherence of perceptions of stakeholders (student, teacher and industry) on what the problem is for which an intervention (e.g. collaborative design of curriculum materials) is needed and how it should be solved. External consistency is reached through a "relational approach", corresponding to the communicative paradigm (Kessels \& Plomp, 1999). It implies the involvement of stakeholders in the design and development process, thereby revealing their perceptions on the main goals of the process and on how they should be achieved. Curriculum work is multifaceted hence the role 
or input of identifiable stakeholders in the design process should be given the utmost consideration. By so doing the divergent needs may be catered for and thereby promote the relevance to its subsequent users.

This study is, therefore, premised on the CCD in design teams as a means to realise both internal and external consistency of the curriculum materials because teachers play a significant role in facilitating teaching and learning (Hattie, 2003) as well as being conversant with what goes on in industry by their training and experience (Heath, 2010). The composition of design teams and their ability to elicit suggestions from other stakeholders in the design of curriculum materials for student internship cannot be overemphasized if quality work is to be ensured (cf. Kessels \& Plomp, 1999). In an effective collaborative design team, there should be the feeling that each other's contribution is required in order to ensure success in their work and new perspectives that colleagues bring on board are not disdained but respected (cf. Hargreaves, 2003; Little, 1990). The dexterity with which to consult, collaborate, seek consensus, and build partnership among teachers is therefore basic to most curriculum work (Walker, 2003), which is geared towards ensuring quality. The collaboration of teachers in teams increases the chance that the curriculum materials designed will become relevant (Plomp, 2009) for student internship. Teachers in teams learn to use conflict and differences as being productive (Grossman, Wineburg, \& Woolworth, 2001).

\subsubsection{Practicality of the curriculum materials in renewed internship}

An effective change strategy must be constructed on a more thorough understanding of the naturally existing internship which operates in authentic learning environments (Blokhuis \& Nijhof, 2008). Stakeholders' perceived attitude supposedly account for the success of use of a curriculum (Doyle \& Ponder, 1975), which is prompted by how its contents and components are systematically aligned (relevance and consistence) to the requirements of end-users. According to Nieveen (2009), the characteristic of high quality curriculum materials is that end-users (stakeholders) consider them to be usable and largely well-suited with the developers' intentions. In this vein, practical use of the materials by stakeholders during internship would be guaranteed and ultimately implementation would be facilitated and the intended objectives of the renewed internship would be achieved with expected outcomes (Sackney, Mitchell, \& Walker, 2005). For instance, a study by Cecil, Fu, and Jones (2010) contend that stakeholders are fairly satisfied with the curriculum designed to improve student 
competencies because stakeholders have their roles defined and the material is equally usable. In another study by Ko (2008) in which stakeholders contribute to the hospitality internship curriculum, interns are satisfied with the internships and the curriculum is perceived as practical and useful.

\subsubsection{Effects and assessment of curriculum materials on students' competencies}

The quality of curriculum materials should not rest on its relevance and consistency phase but on its effects as a result of implementation. Nieveen (2009) terms the desired outcomes as a result of implementing an intervention (curriculum materials) as effectiveness. The main objective of training is to help interns gain knowledge, develop positive attitudes, and apply what they have learned to real life practices (Wilson, Strutton, \& Farris, 2002). Internship, can therefore nurture student's correct work attitude, and cooperation with others (Heppell, 2004). For instance, the student is responsible for adhering to the policies of the industry (Florida Gulf Coast University, 2009). Similarly, inventiveness and human relationship skills are necessary for career success and are also good indicators of employability skills (Kay \& Russette, 2000; Robinson, 2006). Internships are meant to prepare students for the workplace by identifying and developing the important competencies that are believed to be needed by employers (Hodges \& Burchell, 2003). Training promotes higher levels of technical skills (Carlin \& Manson, 2007), which are job specific skills (Wentz \& Trapido-Lurie, 2001). The curriculum materials are hence considered effective if the intended objective is realised in interns.

\subsubsection{Institutional support for renewed internship}

Formalisation of the relationship between school and industry by a written contract specifying tasks of the internship corresponding to the learning objectives and provision of an appropriate insurance are characteristics that foster successful internship (Youth Forum Jeunesse, 2009). An internship coordinator should be designated to provide both the intern and business with information and also intercede when problems arise (Cook, Parker, \& Pettijohn, 2004). Additionally, internship as career related experiences that complement what is learned in the classroom, builds upon the relationship that the educational institution has with employers and is most successful when the student, the department/polytechnic, and the employer all share responsibility in making it a valuable experience (Rothman, 2007). 


\subsubsection{Resolution of implementation challenges}

A renewed student internship seeks to surmount the implementation challenges identified in the context and needs study (Akomaning et al., 2011). Students need timely feedback from both industry-based and academic-based supervisors to perform their operations effectively (Rothman, 2007). This can be achieved through a structured internship, in which students are able to learn skills, improve competencies that increase their future career marketability (Blokhuis \& Nijhof, 2008). Articulating the responsibilities of interns and internship supervisors prior to the internship is a key element in a successful internship (Beggs, Ross, \& Knapp, 2006). Structured internship seeks to offer students the opportunity for professional growth within an organisation through the completion of challenging and meaningful work (Dixon, Cunningham, Sagas, Turner, \& Kent, 2005).

A key component to making an internship programme to stand out is job rotation. It allows interns to rotate among department functions to gain experience in a range of activities (Gillim, 2006). It is important for an intern to be continuously and consistently evaluated from various points of view through periodical evaluations conducted each time the intern rotates into a different section. Workplaces that make efforts to create positive working environments for interns could serve to increase not only their effective commitment to the organizations but also their long-term commitment to the occupation (Dixon et al., 2005). These authors/researchers contend that interns should be treated with the same respect as any employee as friendliness and helpfulness go a long way in affecting an intern's opinion of an organisation.

\subsection{CONTEXT OF THE STUDY}

The training of students to managerial or supervisory position in the hospitality industry in Ghana is provided by the Departments of Hotel Catering and Institutional Management (HCIM), in the polytechnics. The focus of this study is the Department of HCIM, at the Takoradi Polytechnic in Ghana. The HCIM programme in this institution is a three-year tertiary programme which was initiated in 1993. The primary focus of the department is to equip students not only with theoretical knowledge but also with hands-on training so as to improve 
their employability. To fulfil this mission, internship programme forms an integral component of the HCIM programme.

Throughout the entire 3-year programme, students are supposed to undertake at least six months internship. The placement period is carried out in two sessions. Each session covers a period of three months during which interns work in various sections of hospitality industry at the end of the first two academic years. These internship periods are supposed to be supervised by both polytechnic educators and industry representatives. In order to facilitate the internship programmes in the polytechnic, an Industrial Liaison Unit (ILU) has been mandated to facilitate student internship.

\subsection{INTERVENTION}

A summary of the intervention drawn out in this study is shown in Table 4.1. To draw out suggestions for the improvement of internship, teachers, students and industry were first informed about the existing problems with student internship in Ghana's polytechnics (Akomaning et al., 2011). After that, two teams of the HCIM teachers, eight in each group, were formed to collaboratively design curriculum materials for the student internship. One team developed resources material in food production and food and beverage while the other designed materials/resources for accommodation and front office operation (see Appendix C9). The preparation of the curriculum materials as presented in the table below, took about eight weeks.

The curriculum materials had the following components: rationale specifying the distinctive roles of teachers, students and industry, content description of the four core areas of the hospitality industry, practical activities the students had to conduct during internship, job rotation and meaningful jobs assigned during internship and student supervision from teachers and industry. Copies of the final document were made and distributed to all stakeholders before the commencement of internship in 50 hotels. During the student internship (JuneAugust) the Industrial Liaison Officer (ILO) and teachers were expected to supervise the students. 
Table 4.1 Overview of intervention

\begin{tabular}{|c|c|c|c|}
\hline $\begin{array}{l}\text { Date/ } \\
\text { period } \\
\text { March- } \\
\text { Sept } 2010\end{array}$ & Activity & Purpose & $\begin{array}{l}\text { Stakeholders } \\
\text { involved }\end{array}$ \\
\hline March & $\begin{array}{l}\text { Presenting outcomes of } \\
\text { context and needs } \\
\text { analysis }\end{array}$ & $\begin{array}{l}\text { Inform and accept outcomes; } \\
\text { Make contributions for } \\
\text { curriculum materials for } \\
\text { internship }\end{array}$ & $\begin{array}{l}\text { HOD, ILO, } \\
\text { Assistant ILO, } \\
\text { Teachers, } \\
\text { Students, } \\
\text { Industry } \\
\text { representatives }\end{array}$ \\
\hline March & $\begin{array}{l}\text { Workshop on curriculum } \\
\text { design and CCD in } \\
\text { design teams }\end{array}$ & $\begin{array}{l}\text { Basic design principles in } \\
\text { curriculum design and formation } \\
\text { of CCD in design teams }\end{array}$ & HOD, teachers \\
\hline $\begin{array}{l}\text { March- } \\
\text { May }\end{array}$ & $\begin{array}{l}\text { Collaborative design of } \\
\text { curriculum materials, } \\
\text { taking on board } \\
\text { suggestions from } \\
\text { industry and students }\end{array}$ & $\begin{array}{l}\text { To prepare curriculum materials } \\
\text { to improve internship }\end{array}$ & $\begin{array}{l}\text { CCD in design } \\
\text { teams }\end{array}$ \\
\hline May & $\begin{array}{l}\text { Compilation of } \\
\text { documents into draft } \\
\text { curriculum materials }\end{array}$ & $\begin{array}{l}\text { Copies made for stakeholders to } \\
\text { get further input }\end{array}$ & $\begin{array}{l}\text { Teachers, } \\
\text { students, } \\
\text { industry } \\
\text { representatives }\end{array}$ \\
\hline May-June & $\begin{array}{l}\text { Final curriculum } \\
\text { materials }\end{array}$ & $\begin{array}{l}\text { Distribution to stakeholders as a } \\
\text { working document for internship }\end{array}$ & $\begin{array}{l}\text { Teachers, ILO, } \\
\text { students, } \\
\text { industry }\end{array}$ \\
\hline $\begin{array}{l}\text { June- } \\
\text { August }\end{array}$ & Students on internship & $\begin{array}{l}\text { Industrial training using } \\
\text { curriculum materials to improve } \\
\text { internship }\end{array}$ & $\begin{array}{l}\text { Students, } \\
\text { teachers and } \\
\text { industry, ILO }\end{array}$ \\
\hline
\end{tabular}

\subsection{RESEARCH QUESTIONS}

The main research question framing the study is: Do the curriculum materials produced by the design teams contribute to renewed student internship according to the stakeholders involved?

The following sub-questions have been formulated for the study:

1. How do the design teams ensure the quality of the curriculum materials designed for the renewed student internship?

2. How do stakeholders (students, teachers, industry personnel) perceive the practical use of the curriculum materials? 
3. How have stakeholders (students, teachers and industry personnel) assessed the competencies students gained from the renewed internship?

4. To what extent are stakeholders (students, teachers, industry personnel) satisfied with the institutional support offered to realise the renewed student internship?

5. To what extent are the implementation challenges of student internship resolved?

\subsection{METHODS}

\subsubsection{Participants}

Sixteen out of 22 HCIM teachers participated in two design teams. Six of them had previous experience in curriculum development. The ILO participated in the study because he plays a pivotal role in the organisation of internships and is the link between the polytechnic and industry. Fifty organisations where students were placed for their internship also took part in the study. A total of 165 first $(N=104)$ and second $(N=61)$ year students took part in the workshops at the start of the intervention. One hundred and forty-three (students available at the time of administering questionnaire) out of the 165 students participated in the data collection at the end of the intervention. Of those 143, 89 and 54 were first and second year students respectively.

\subsubsection{Research instrumentation}

Table 4.2 presents the overview of research instruments administered (see Appendices B and C).

Table 4.2 Overview of instrument administration

\begin{tabular}{|c|c|c|c|c|c|c|c|c|c|c|c|c|}
\hline 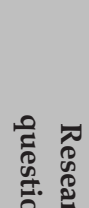 & 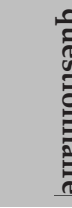 & 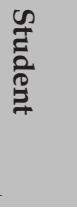 & . & 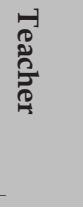 & 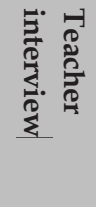 & 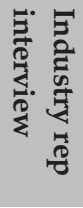 & 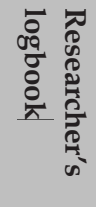 & & 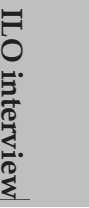 & $\widehat{\ominus}$ & 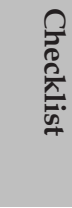 & 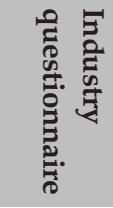 \\
\hline 官 & Pre & Post & Pre & Post & & & & Pre & Post & & & $1^{s t} \quad 2^{n c}$ \\
\hline RQ 1 & & & $x$ & $X$ & & $X$ & $X$ & & & $x$ & & \\
\hline RQ 2 & & $x$ & & $x$ & $X$ & & & $X$ & & & $X$ & $X$ \\
\hline RQ 3 & & $x$ & & $x$ & $X$ & & & & & & & $X$ \\
\hline RQ 4 & & $x$ & & $X$ & & & & & $X$ & & & $X$ \\
\hline RQ 5 & $X$ & $x$ & & $X$ & & & & & $X$ & & $X$ & $X$ \\
\hline
\end{tabular}


Students' instruments: A focus group discussion (FGD) with students discussed suggestions for improvement of internship. Two sets of questionnaires were administered to students. The first was administered after the FGDs. It had two parts: the first part was based on year groups. The second part centred on student self-assessment of their competencies in the four core domains in the hospitality management programme. The questionnaires contained predominantly close-ended statements and some few open-ended questions. The closed items had a five-point Likert scale using responses ranging from strongly disagree (1) to strongly agree (5). The second questionnaire, similar to the first, was administered immediately after internship six months later. The open-ended questions focused on year group, place of first and second internships and duration. Others were sections of industry where student trained, and brief description of competencies acquired in the recent internship. The close-ended statements were similar to the first questionnaire except for additions about employers' satisfaction with job performance and assessment of the curriculum materials (see Appendices B2, B3 and B6).

Teachers' questionnaires and interview: Two sets of questionnaires were administered to teachers. The first was immediately after the workshops in March. The rationale was to elicit background information on teacher experience in curriculum design activities (open-ended questions) and the teachers' collaborative skills to ensure quality design (close-ended statements), which sought to answer research question 1. Research question 2 was dealt with in both teacher questionnaire and interview on the practical use of the curriculum. Research question 3 was addressed by job performance of students during the internship. Statements on institutional support regarding the polytechnic's link with industry, prior contact with industry before students went on internship and polytechnic looks for places for students for internship sought to answer research question 4. An open-ended question and close-ended statements on supervision of students during internship by teachers and industry-based supervisors answered research question 5 (see Appendices C1, C7 and C8).

ILO's interview: The ILO was interviewed before and after the 2010 internship concerning implementation of internship, supervision, challenges, practical use of the curriculum materials on internship, teacher role, and polytechnic contribution to the internship. ILO's interview contributed in answering research questions 2, 4 and 5 (see Appendices C3 and C6). 
Interview and questionnaire to industry personnel: All the 50 workplaces visited were given the curriculum materials and questionnaire. Forty-one out of the 50 responded to the questionnaire $(82 \%)$. Five were interviewed at the start of the study regarding challenges and suggestions for improvement in student internship programme. Data from these interviews contributes in answering research question 1. Questionnaire (1st) to industry was mainly close-ended (a five-point Likert scale with responses ranging from 1 to 5 representing strongly disagree and strongly agree respectively) with some few open-ended questions. The open-ended question on the practical use of the curriculum materials during student internship addresses research question 2. Industry assessment of students' competencies during internship (2nd questionnaire from student logbooks) with rating scale of 1 to 5 representing weak and outstanding respectively, and a statement from $1^{\text {st }}$ questionnaire on whether employers are satisfied with students' job performance sought to address research question 3 . Formalisation of polytechnic-industry link, polytechnic made prior contacts with industry before students went on internship while the polytechnic looked for places for students to practise are statements that address research question 4 on institutional support for internship. Statements which focus on teacher and industry supervision of students during internship also seek to deal with research question 5. Administration of this instrument was done after personnel were briefed on the curriculum materials. These were hotels where students had internship in 2010. Retrieval of instrument was carried out by interns after internship and submitted to the researcher in September when they returned to the polytechnic (see Appendices B5, C2 and C5).

Checklist and researcher's logbook: This instrument (checklist) was used to collect data on students' visits by the researcher in the hotel industry. The purpose was to know at first-hand the state of interns and to interact with personnel of organisations concerning interns' general behaviour. Student assigned roles, industry training, working environment, industry supervision, teacher supervision, competencies expected and competencies achieved were the indices being investigated. In all 89 interns were visited in 50 hotels. Researcher's logbook captured the initial arrangements for workshops for ILO, teachers, students and industry representatives and design process of curriculum materials (see Appendices B4 and C4). 


\subsubsection{Data analysis}

Data were analysed qualitatively and quantitatively. Descriptive were used to determine the means and standard deviations expressed by teachers in design teams on collaborative activities to determine differences between pre- and post-means. Descriptives were also used to determine the perception of use of curriculum materials, industry contribution to internship, industry assessment of students' competencies and evaluation of institutional support by teachers. Chi-square was used to determine differences expressed in views by stakeholders regarding internship supervision, students' job performance during internship and assessment of polytechnic support for internship. Data from checklist were analysed by use of percentages to identify the major themes and to present them accordingly.

All interviews were audio taped, transcribed and coded using codes generated from the study. The coding schemes (Bogdan \& Biklen, 1992; Miles \& Huberman, 1994) were labelled: expected roles of stakeholders specified, regular reviews of curriculum, teacher role in internship, internship streamlined, students' commitment to internship and polytechnic support design teams. The version 6.2 of Atlas-ti software was used for the coding of all the interview data. Intercoder reliability (Lombard et al., 2002; Neuendorf, 2002) was calculated using a random sample of 10 interviews from 16 teachers. There were two coders including the researcher. The intercoder reliability using Cohen's kappa (k) was 0.85 . Information recorded in the logbook and checklist was analyzed qualitatively using data reduction technique. Major themes were identified and clustered (Miles \& Huberman, 1994).

\subsection{RESULTS}

\subsubsection{How do design teams ensure quality of curriculum materials?}

Essentially, suggestions from students, industry representatives and teachers on improvement in student internship are similar. These similarities border on supervision, seriousness of interns, workers cooperating with interns and incentives given to interns to motivate them to give off their best (data from researcher's logbook, student focus group discussion and industry representatives' interview). Additional data from industry suggests that interns should ask questions, teachers should visit industry regularly; document should be practically-oriented and focused on customer satisfaction. Similarly, teachers 
and students express that testimonial should be given to interns to attest for the training, meaningful and challenging work assigned and interns are to serve in all departments of industry. All these data are factored into the design of the curriculum materials. Design teams share their experiences in current internships that teachers have had in some top-class hotels in Ghana; draft materials are sent to stakeholders for scrutiny; and collated suggestions infused in draft materials for the final curriculum materials. The documents are collaboratively prepared with the view to satisfy stakeholders and to be of relevance to industry where students have their internship. They ensured that the curriculum materials cover the four core domains of the HCIM programme (food production, food and beverage service, front office and accommodation operations).

The commonality of the terms suggests the consistency with which stakeholders would want the curriculum materials to serve the interest of all. Hospitality industries differ in terms of facilities - well-endowed and less-endowed. The former being equipped with the state-of-the-art facilities while the latter lacks these facilities. In order to serve the interest of all such workplaces, design teams took into account the variability in designing the curriculum materials.

Table 4.3 takes cognisance of the before- (before joining design teams) and after(after internship) teachers' perceptions about their work in teams. Teachers collaborated in their teams for about eight weeks to ensure the quality of curriculum materials designed. With the exceptions to the variables: Knowing how to keep conflict situation moving towards productive situation in team $\left(M_{1}=3.7\right.$, $\left.\mathrm{SD}=0.79 ; M_{2}=4.2, \mathrm{SD}=0.54\right)$, Feeling of being part of what goes on in team $\left(M_{1}=4.3\right.$, $\mathrm{SD}=0.87 ; M_{2}=4.7, \mathrm{SD}=0.48$ ) and Knowing how to employ participative decision making techniques in team $\left(M_{1}=4.1, \mathrm{SD}=0.57 ; M_{2}=4.3, \mathrm{SD}=0.60\right)$ whose after-means increased. The before-means (3.70-4.4) and after-means (4.2-4.7) appear considerably high.

Finally, teachers invited the suggestions from industry representatives and students in the preparation of the curriculum materials for student internship. Teachers used their rich experiences in the industry coupled with the use of relevant materials to design the curriculum materials. Teachers collaborated in teams endeavouring that there was consistency in the products designed. 
Table 4.3 Collaborative efforts of teachers in design teams

\begin{tabular}{|c|c|c|c|c|}
\hline \multirow[b]{2}{*}{ Statement } & \multicolumn{2}{|c|}{ Before $(N=16)$} & \multicolumn{2}{|c|}{ After $(N=16)$} \\
\hline & Mean & $S D$ & Mean & $S D$ \\
\hline I do quality work in team & 4.4 & 0.63 & 4.3 & 0.68 \\
\hline Better organised work in team & 4.2 & 0.66 & 4.2 & 0.75 \\
\hline $\begin{array}{l}\text { Content knowledge of curriculum } \\
\text { materials is accepted by consensus }\end{array}$ & 4.0 & 0.82 & 4.3 & 0.58 \\
\hline $\begin{array}{l}\text { Growing understanding of influence of } \\
\text { curriculum materials on internship }\end{array}$ & 4.3 & 0.79 & 4.4 & 0.51 \\
\hline $\begin{array}{l}\text { Knowing how to keep conflict situation } \\
\text { moving towards productive situation in } \\
\text { team }\end{array}$ & 3.7 & 0.79 & 4.2 & 0.54 \\
\hline $\begin{array}{l}\text { Feeling of being part of what goes on in } \\
\text { team }\end{array}$ & 4.3 & 0.87 & 4.7 & 0.48 \\
\hline $\begin{array}{l}\text { Knowing how to employ participative } \\
\text { decision making techniques in team }\end{array}$ & 4.1 & 0.57 & 4.3 & 0.60 \\
\hline
\end{tabular}

Note: Rating scale: 1 , strongly disagree; 2 , disagree; 3 , neutral; 4, agree; 5 , strongly agree; SD, standard deviation.

\subsubsection{Practical use of student internship guide}

Student perspective

Students' perception of the internship guide for internship is presented in Table 4.4. Means from student data are generally high, ranging from 4.2 to 4.5 with standard deviations between 0.57 and 0.76 . The checklist confirms that students who were visited during the internship period were content with the document. They used the materials as a reference document and as a material that enabled them to report on their industrial experience using the technical concepts in the hospitality industry appropriately in their description.

Table 4.4 Perception of student guide for internship

\begin{tabular}{lllcc} 
Year & & & & \\
Group & $N$ & Statement & Mean & Std. Dev. \\
HND I & 89 & Internship guide helps during & 4.2 & 0.65 \\
HND II & 54 & internship. & 4.4 & 0.76 \\
\hline HND I & 89 & Internship guide helps to write & 4.3 & 0.64 \\
HND II & 54 & industrial report. & 4.5 & 0.57
\end{tabular}

Note: Rating scale: 1 , strongly disagree; 2 , disagree; 3 , neutral; 4 , agree; 5 , strongly agree. 


\section{Teacher/ILO perspectives}

Teachers' views from the teacher questionnaire data, ILO and teacher interviews on practical use of the curriculum materials for student internship are summarised in this section. According to the teachers and the ILO, the curriculum materials have improved internship programme in that students are more aware of what is expected of them, and the managers at the various hospitality industry also know the various sections students are to be trained. They indicate the documents serve as a guide for students when they go for industrial training, which in turn, delve into more areas for practical skills acquisition. According to the teachers the curriculum materials have helped to streamline what students are really supposed to learn on-the-job and thereby brought a big relief to students and industry personnel. However, two of the 16 teachers remark the dynamic nature of the hospitality industry calls for regular reviews of the curriculum in order to reflect the changes in the industry.

The following are comments from teachers (seven out of the 16) who were not part of the polytechnic internship supervision team however could make inferences from students' industrial reports and conversation with students: Teacher A, "I have marked some of the students' reports and I think students were placed at where they should really have the experience from what they wrote for us to mark."

\section{Teacher B}

...I have started marking (the reports) I think students really went out into those hospitality industries to acquire certain skills that we were hoping for them to acquire. Their reports attest to the fact that they really learnt a lot from the industry. The various organisations whereby they were assigned were also pleased to have them...

Interview teacher $\mathrm{C}$ could gather relevant information from conversation with students and reports. Her observation states that:

Students really had a lot to say about this new development because when they went out to the industry, copies have been placed there so they knew what exactly where they had to go and work... So, to a large extent the curriculum materials have really helped the students. Some of the students' reports suggest that the curriculum materials sent to the managers were used. 
The ILO (interview), comments,

... When I went round I saw that it (the student internship guide) was very good material because it would actually help us in supervision... And the teachers too, will be guided in their teaching and may train students who will fit the hospitality industry.

\section{Industry perspective}

Industry questionnaire data on the practical use of the curriculum materials for student internship as described by industry personnel are as follows: the curriculum materials have given room for proper industrial assessment on conduct and performance of students. They have helped in monitoring students on internship and brought about discipline within establishments. One of the managers remarks that the curriculum materials, "...have helped me to know what exactly students were to go through ... enabled students to take internship more seriously;...given industry a sense of direction as far as what to teach was concerned." Another manager says, "I think they equipped students for their future assignment." The curriculum materials specify what the students ought to know and look for. They have given direction for training the students. The curriculum materials have added value to students' studies. 'Highly', 'satisfactory' and 'very well' are some words used by some of the industry personnel to express the practical use of the curriculum materials. They have given students the room to improve upon whatever skills they knew since there is a vast difference between what is taught at school and what industry does. Thus, the curriculum materials have helped management to allow students work in different departments in the hotel.

Further general assertions made by managers about the curriculum materials indicate the resources have brought improvement in students' performance and seriousness in learning whilst on training. They have given students some ideas about what actually goes on in hotel industry. They also make work easier on the practical field and students become experienced in the practical work. The curriculum materials have been practically useful in the sense that they gave students prior knowledge of what to expect in the industry. The curriculum materials have instilled confidence in students. A good guidance to ensure all areas was captured. Finally, these were comments from a manager of a hotel, "The curriculum materials have helped us a lot to learn more about the polytechnic and its internship programme." 


\subsubsection{Competencies of students}

Tables 4.5, 4.6, 4.7 and 4.8 depict competencies gained by students during internship in the four core areas in the hospitality industry which could be partly due to the use of the designed curriculum materials. These competencies are selfassessed as follows.

\section{Food production}

Four items couched under food preparation methods are: ability to cook for required number of guests, familiar with the use of kitchen tools and equipment, ability to prepare dishes using a variety of commodities and familiar with all methods of cooking. Whilst food preparation consists of the ability to prepare, cook and present Ghanaian ethnic and international dishes, ability to use various methods of preservation and ability to identify the procedures to follow once an order has been received as presented in Table 4.5. The differences between the pre-test and post-test means were all significant. It is noteworthy that the effect sizes range from small to large (.39 to .80).

Table 4.5 Competencies of students in food production

\begin{tabular}{|c|c|c|c|c|c|c|c|c|c|}
\hline \multirow[b]{2}{*}{ HND } & \multirow[b]{2}{*}{$N$} & \multirow[b]{2}{*}{ Competency } & \multicolumn{2}{|c|}{ Pre-test } & \multicolumn{3}{|c|}{ Post-test } & \multirow[b]{2}{*}{$T$} & \multirow{2}{*}{$\begin{array}{c}\text { Effect } \\
\text { size }\end{array}$} \\
\hline & & & Mean & $S D$ & Mean & $S D$ & Sig. & & \\
\hline 1 & 104 & Food & 3.8 & 0.63 & & & & & \\
\hline 1 & 89 & $\begin{array}{l}\text { preparation } \\
\text { methods }\end{array}$ & & & 4.0 & 0.56 & $0.008^{*}$ & -2.681 & 0.39 \\
\hline 1 & 104 & Food & 3.4 & 0.66 & & & $00005 *$ & 5546 & 080 \\
\hline 1 & 89 & preparation & & & 3.8 & 0.55 & 0.0000 & -0.040 & 0.00 \\
\hline 2 & 61 & Food & 3.8 & 0.76 & & & & & \\
\hline 2 & 54 & $\begin{array}{l}\text { preparation } \\
\text { methods }\end{array}$ & & & 4.2 & 0.53 & $0.0005^{*}$ & -3.704 & 0.50 \\
\hline 2 & 61 & Food & 3.6 & 0.53 & & & $0 \Omega 02 *$ & 3012 & 069 \\
\hline 2 & 54 & preparation & & & 3.9 & 0.60 & 0.003 & -3.013 & 0.09 \\
\hline
\end{tabular}

Note: SD, Standard deviation; ${ }^{*} p<0.05$.

\section{Food and beverage service}

Competencies of students in food and beverage service are shown in Table 4.6. The competencies are phrased under skills in restaurant service and customer care. The former consists of ability to wait on customers, co-operation with and assistance to others, ability to serve food and drink well, acquisition of skills to promote customer satisfaction and ability to use the right equipment in restaurant 
service. The latter captures competencies like designing and producing promotional material, including point of sale advertisements for special events, ability to resolve guests' complaints, the use, cleaning and maintenance of equipment in a safe professional manner and ability to lay tables for different functions at the restaurant. There have been significant differences between before and after means for skills in restaurant service and customer care as shown in the table below. Effect sizes range from small to medium (.38 to .76$)$.

Table 4.6 Competencies of students in food and beverage service

\begin{tabular}{|c|c|c|c|c|c|c|c|c|c|}
\hline \multirow[b]{2}{*}{ HND } & \multirow[b]{2}{*}{$N$} & \multirow[b]{2}{*}{ Competency } & \multicolumn{2}{|c|}{ Pre-test } & \multicolumn{2}{|c|}{ Post-test } & \multirow[b]{2}{*}{ Sig. } & \multirow[b]{2}{*}{$\mathrm{T}$} & \multirow{2}{*}{$\begin{array}{c}\text { Effect } \\
\text { Size }\end{array}$} \\
\hline & & & Mean & $S D$ & Mean & $S D$ & & & \\
\hline 1 & 104 & \multirow{2}{*}{$\begin{array}{l}\text { Skills in } \\
\text { restaurant } \\
\text { service }\end{array}$} & \multirow[t]{2}{*}{3.7} & \multirow[t]{2}{*}{0.65} & & & & & \\
\hline 1 & 89 & & & & 4.2 & 0.53 & $0.0005^{*}$ & -5.143 & 0.74 \\
\hline 1 & 104 & \multirow{2}{*}{$\begin{array}{l}\text { Customer } \\
\text { care }\end{array}$} & \multirow[t]{2}{*}{3.2} & \multirow[t]{2}{*}{0.67} & & & \multirow{2}{*}{$0.0005^{\star}$} & \multirow{2}{*}{-5.242} & \multirow{2}{*}{0.76} \\
\hline 1 & 89 & & & & 3.7 & 0.61 & & & \\
\hline 2 & 61 & \multirow{2}{*}{$\begin{array}{l}\text { Skills in } \\
\text { restaurant } \\
\text { service }\end{array}$} & \multirow[t]{2}{*}{4.0} & \multirow[t]{2}{*}{0.47} & & & & & \\
\hline 2 & 54 & & & & 4.2 & 0.54 & $0.041^{*}$ & -2.063 & 0.38 \\
\hline 2 & 61 & \multirow{2}{*}{$\begin{array}{l}\text { Customer } \\
\text { care }\end{array}$} & \multirow[t]{2}{*}{3.5} & \multirow[t]{2}{*}{0.592} & & & \multirow{2}{*}{$0.0005^{*}$} & \multirow{2}{*}{-3.634} & \multirow{2}{*}{0.71} \\
\hline 2 & 54 & & & & 3.9 & 0.54 & & & \\
\hline
\end{tabular}

Note: SD, Standard deviation; ${ }^{*} p<0.05$.

\section{Front office operation}

Competencies in front office operation are couched as skills in front office and front office records (Table 4.7). The former comprises competencies like identification of types of reservations in hospitality industry, familiarity with scope of the lodging/hotel industry, identification of different types of accommodation facilities, functions of the front office and its personnel and understanding of the accounting system at the front office. The latter is composed of ability to identify different room types and abbreviations used, understanding the grading system used in rating hotels in Ghana, ability to handle guest enquiries, reservation records forecasting and knowing the check-out procedures and settlement. The study shows significant differences between pre-test and post-test means. Effect sizes range from small to medium (.48 to .63). 
Table 4.7 Competencies of students in front office operation

\begin{tabular}{|c|c|c|c|c|c|c|c|c|c|}
\hline \multirow[b]{2}{*}{ HND } & \multirow[b]{2}{*}{$N$} & \multirow[t]{2}{*}{ Competency } & \multicolumn{2}{|c|}{ Pre-test } & \multicolumn{2}{|c|}{ Post-test } & \multirow[b]{2}{*}{$\mathrm{T}$} & \multirow[b]{2}{*}{ Sig. } & \multirow{2}{*}{$\begin{array}{c}\text { Effect } \\
\text { Size }\end{array}$} \\
\hline & & & Mean & SD & Mean & SD & & & \\
\hline 1 & 104 & \multirow{2}{*}{$\begin{array}{l}\text { Skills in front } \\
\text { office }\end{array}$} & \multirow[t]{2}{*}{3.5} & \multirow[t]{2}{*}{0.67} & & & \multirow{2}{*}{-4.381} & \multirow{2}{*}{$0.0005^{*}$} & \multirow{2}{*}{0.63} \\
\hline 1 & 89 & & & & 3.9 & 0.62 & & & \\
\hline 1 & 104 & \multirow{2}{*}{$\begin{array}{l}\text { Front office } \\
\text { records }\end{array}$} & \multirow[t]{2}{*}{3.6} & \multirow[t]{2}{*}{0.72} & & & \multirow{2}{*}{-4.154} & \multirow{2}{*}{$0.0005^{*}$} & \multirow{2}{*}{0.60} \\
\hline 1 & 89 & & & & 4.0 & 0.63 & & & \\
\hline 2 & 61 & \multirow{2}{*}{$\begin{array}{l}\text { Skills in front } \\
\text { office }\end{array}$} & \multirow[t]{2}{*}{3.7} & \multirow[t]{2}{*}{0.67} & & & \multirow{2}{*}{-2.740} & \multirow{2}{*}{$0.007^{*}$} & \multirow{2}{*}{0.48} \\
\hline 2 & 54 & & & & 4.0 & 0.54 & & & \\
\hline 2 & 61 & \multirow{2}{*}{$\begin{array}{l}\text { Front office } \\
\text { records }\end{array}$} & \multirow[t]{2}{*}{3.9} & \multirow[t]{2}{*}{0.66} & & & \multirow{2}{*}{-3.346} & \multirow{2}{*}{$0.001^{*}$} & \multirow{2}{*}{0.59} \\
\hline 2 & 54 & & & & 4.3 & 0.51 & & & \\
\hline
\end{tabular}

Note: SD, Standard deviation; ${ }^{*} p<0.05$.

\section{Accommodation operation}

The study findings on accommodation operation as presented in Table 4.8, depicts the competencies of students in accommodation operation. Competencies like cleaning of materials using correct agent and equipment, caring for and cleaning of different floors types, cleaning and caring for bathroom/toilet and ceilings and wall coverings and application of hotel and catering laws are expressed as skills in housekeeping. Whilst familiar with the housekeeping department, its organisation and its relationship with departments, familiar with different types of materials used throughout room interiors and understanding the use of various cleaning agents and equipment are phrased housekeeping operations. The evidence shows below, thus, significant differences between pretest and post-test means for both first and second year students. For instance the after-mean competency of first year students in skills in housekeeping ( $M=4.1$, $\mathrm{SD}=0.58)$ is significantly higher $(t=-5.463$, two-tailed $p=0.0005)$ than that of the pre-test competency $(M=3.6, \mathrm{SD}=0.64)$ whereas second year students post-test mean competency $(M=4.0, \mathrm{SD}=0.60)$ is significantly higher ( $t=-3.616$, two-tailed $p=0.0005)$ than that of the pre-test competency $(M=3.6, \mathrm{SD}=0.84)$. The effect sizes range from medium to large effect (.63 to .99). 
Table 4.8 Competencies of students in accommodation operation

\begin{tabular}{|c|c|c|c|c|c|c|c|c|c|}
\hline \multirow[b]{2}{*}{ HND } & \multirow[b]{2}{*}{$N$} & \multirow[b]{2}{*}{ Competency } & \multicolumn{2}{|c|}{ Pre-test } & \multicolumn{2}{|c|}{ Post-test } & \multirow[b]{2}{*}{$\mathrm{T}$} & \multirow[b]{2}{*}{ Sig. } & \multirow{2}{*}{$\begin{array}{l}\text { Effect } \\
\text { Size }\end{array}$} \\
\hline & & & Mean & $\mathrm{SD}$ & Mean & SD & & & \\
\hline 1 & 104 & \multirow{2}{*}{$\begin{array}{l}\text { Skills in } \\
\text { housekeeping }\end{array}$} & \multirow[t]{2}{*}{3.6} & \multirow[t]{2}{*}{0.64} & & & \multirow{2}{*}{-5.463} & \multirow{2}{*}{$0.0005^{*}$} & \multirow{2}{*}{0.79} \\
\hline 1 & 89 & & & & 4.1 & 0.58 & & & \\
\hline 1 & 104 & \multirow{2}{*}{$\begin{array}{l}\text { Housekeepin } \\
\text { g operations }\end{array}$} & \multirow[t]{2}{*}{3.6} & \multirow[t]{2}{*}{0.72} & & & \multirow{2}{*}{-6.784} & \multirow{2}{*}{$0.0005^{*}$} & \multirow{2}{*}{0.99} \\
\hline 1 & 89 & & & & 4.2 & 0.55 & & & \\
\hline 2 & 61 & \multirow{2}{*}{$\begin{array}{l}\text { Skills in } \\
\text { housekeeping }\end{array}$} & \multirow[t]{2}{*}{3.6} & \multirow[t]{2}{*}{0.84} & & & \multirow{2}{*}{-3.616} & \multirow{2}{*}{$0.0005^{*}$} & \multirow{2}{*}{0.63} \\
\hline 2 & 54 & & & & 4.0 & 0.60 & & & \\
\hline 2 & 61 & Housekeepin & \multirow[t]{2}{*}{3.6} & \multirow[t]{2}{*}{0.63} & & & \multirow{2}{*}{-4.610} & \multirow{2}{*}{$0.0005^{*}$} & \multirow{2}{*}{0.84} \\
\hline 2 & 54 & g operations & & & 4.2 & 0.58 & & & \\
\hline
\end{tabular}

Note: SD, Standard deviation; ${ }^{*} p<0.05$

\section{Industry perspective}

This section considers assessment of students' competencies by industry (data from student logbooks which includes assessment). Table 4.9 illustrates the assessment of students by industry personnel. Students' ability to understanding issues, ability to use hands, ability to give judgment are couched under specific skills whereas attendance to work, punctuality, desire to work and willingness to accept new ideas and suggestions are phrased as attitude to work. Human relationship consists of relationship with subordinates, colleagues, superiors and emotional stability. Inventiveness and adherence are expressed under Employability skills. Furthermore, resourcefulness, ability to take initiative, to work with little supervision, to work with other staff and to adhere to safety and environmental rules make up the constituents of inventiveness whilst ability to follow instructions carefully, adherence to organisation's rules and regulations and ability to complete work on schedule constitute adherence. It can be observed that on all the constructs industry personnel appear to score high means (4.1 to 4.4) implying students' competencies are above the rating mark of good.

Table 4.9 Industry assessment of students' competencies $(N=50)$

\begin{tabular}{lcc} 
Competency & Mean & Std. Dev. \\
\hline Specific skills (technical skills) & 4.1 & 0.50 \\
\hline Attitude to work & 4.4 & 0.44 \\
\hline Human relationship & 4.4 & 0.44 \\
\hline Employable: Inventiveness & 4.2 & 0.48 \\
\hline Employable: Adherence & 4.4 & 0.51
\end{tabular}

Note: Rating scale: 1 , weak; 2 , below average; 3 , average; 4 , good; 5 , outstanding. 
Teacher, student and industry perspectives

The teachers (13 out of 16) interviewed indicate that students are committed, a new emerging construct, to internship. From teacher, student and industry data, stakeholders have expressed their satisfaction to the job performance of students (Table 4.10). However, evidence from Industry personnel (mean=3.8) shows more positive outcome than that of the teachers (mean=3.5). This shows significant difference between teachers/industry and students $\left(X^{2}=30.34, p=0.0005\right)$.

Table 4.10 Assessment of students

\begin{tabular}{lcccccccccc} 
& $\begin{array}{c}\text { Stakehold } \\
\text { ers } \\
(N=143)\end{array}$ & \multicolumn{2}{c}{$\begin{array}{c}\text { Teachers } \\
(N=16)\end{array}$} & \multicolumn{2}{c}{$\begin{array}{c}\text { Industry } \\
(N=41)\end{array}$} & & & \\
\cline { 2 - 5 } & Mean & $S D$ & Mean & SD & Mean & SD & $X^{2}$ & Sig. \\
Statement & 4.4 & 0.62 & 3.5 & 0.82 & 3.8 & 0.90 & 30.34 & $0.0005^{*}$ \\
Employers' satisfaction with & & & & & & & &
\end{tabular}

Note: Rating scale: 1 , strongly disagree; 2, disagree; 3 , neutral; 4, agree; 5 , strongly agree; SD, standard deviation; ${ }^{*} p<0.05$.

Generally, students have improved on their competencies in all the four core areas of the hospitality industry where they served during internship. Stakeholders also appear satisfied with students' competencies gained during the internship. Industry assessment of students is very satisfactory and connotes students' gradual smooth transition to the world of work. The improvements in competencies of students could be partly due to the use of the designed curriculum materials.

\subsubsection{Institutional support}

Table 4.11 depicts polytechnic support for student internship. Concerning the polytechnic-industry relationship being formalised, that of industry indicates the least mean of 2.6 whilst teachers' show the highest (4.2). This demonstrates a significant difference between students/teachers and industry $\left(X^{2}=17.96, p=.0005\right)$. The relatively low mean from industry signifies they are not wholly satisfied with the formalisation of relationship with the polytechnic. The teachers on the other hand perceive the relationship formalised because aside from the regular mandated student internship organised by the polytechnic, the Department of HCIM has come out with another internship where students during the academic semester practise in the hospitality industry in and around Takoradi where the polytechnic writes officially to the industry requesting for permission for students to practise in 
their organisations. The ILO in an interview did indicate that the relationship between the polytechnic and industry has been formalised.

Table 4.11 Assessment of polytechnic support

\begin{tabular}{|c|c|c|c|c|c|c|c|c|}
\hline \multirow[b]{2}{*}{ Statement } & \multicolumn{2}{|c|}{$\begin{array}{l}\text { Students } \\
(N=143)\end{array}$} & \multicolumn{2}{|c|}{$\begin{array}{c}\text { Teachers } \\
(N=16)\end{array}$} & \multicolumn{2}{|c|}{$\begin{array}{c}\text { Industry } \\
(N=41)\end{array}$} & \multirow[b]{2}{*}{$X^{2}$} & \multirow[b]{2}{*}{ Sig. } \\
\hline & Mean & $S D$ & Mean & $S D$ & Mean & $S D$ & & \\
\hline $\begin{array}{l}\text { Formal agreement between } \\
\text { polytechnic and industries. }\end{array}$ & 3.2 & 1.32 & 4.2 & 0.91 & 2.6 & 1.12 & 17.96 & $0.0005^{*}$ \\
\hline $\begin{array}{l}\text { Polytechnic makes prior contacts } \\
\text { with industries before students } \\
\text { go for internship. }\end{array}$ & 2.9 & 1.53 & 4.4 & 0.81 & 3.1 & 1.42 & 16.84 & $0.0005^{*}$ \\
\hline $\begin{array}{l}\text { Polytechnic looks for industries } \\
\text { for students to practise. }\end{array}$ & 2.3 & 1.32 & 3.3 & 1.34 & 2.5 & 1.23 & 10.07 & $0.007^{*}$ \\
\hline
\end{tabular}

Note: rating scale: 1 , strongly disagree; 2 , disagree; 3 , neutral; 4 , agree; 5 , strongly agree; SD, standard deviation; ${ }^{*} p<0.05$.

According to ILO the polytechnic prior contacts with industries were oftentimes prompted by some industry personnel who had shown interest in students taking up internship in their establishments. The usual practice was that students went looking for placements. It is against this backdrop that some students sometimes delay in starting internship. The polytechnic came in when students' attempts had completely failed. This study, therefore, indicates that teachers are the most satisfied as seen in the following significant differences [(polytechnic makes prior contacts with industry: students/industry and teachers $\left(X^{2}=16.84, p=.0005\right)$; Polytechnic looks for industry for students to practise: students and teachers $\left.\left(X^{2}=10.07, p=.007\right)\right]$. Generally, teachers are more positive toward polytechnic support than students and industry.

It can be said that the polytechnic has shown some level of commitment towards student internship (Table 4.12). The evaluation of the polytechnic support for internship by teachers suggests means in the magnitude of 3.6 and 3.8. Takoradi Polytechnic has improved on its activities with internship however adequate resources need to be committed to teacher supervision since it is a way of ensuring that students are at post and are moreover carrying out their duties as expected. 
Table 4.12 Teachers' evaluation of student internship $(N=16)$

\begin{tabular}{lccc} 
Statement & Mean & Std. Dev. \\
\hline $\begin{array}{l}\text { Improvement (as compare to previous years) in polytechnic support } \\
\text { for organising internship programme. }\end{array}$ & 3.8 & 0.93 \\
\hline Activities of ILU towards internship programme have improved. & 3.8 & 0.75 \\
\hline Internship letters to industry are received on time. & 3.6 & 0.89
\end{tabular}

Note: rating scale: 1 , strongly disagree; 2 , disagree; 3 , neutral; 4 , agree; 5 , strongly agree

In an interview with teachers, they collectively acknowledge that in the preparation of the curriculum materials for internship, the polytechnic provided teachers time, space and relevant documents. They are, therefore, quite grateful for the utilised institutional resources by the design teams.

\subsubsection{Resolution of implementation challenges}

Perspectives of stakeholders on supervision

Table 4.13 presents supervision of students from the views of students, industry and teachers. Stakeholders generally accept that teachers (polytechnic internship supervision team) supervised students' work during internship with means ranging from 3.7 to 4.6, which shows significant difference between students/teachers and industry $\left(X^{2}=25.49, p=.0005\right)$. The response as to whether these supervisions are enough shows that teachers and students are quite satisfied than that of industry (mean=3.0). Of 89 students visited by the researcher during the internship about $90 \%$ of them had been supervised once by teachers (researcher's checklist). Again, whether Industry supervisors ensured proper supervision of students has yielded means of 4.0, 3.8 and 4.4 respectively for students, teachers and industry. There is significant difference between students/industry and teachers $\left(X^{2}=10.19 ; p=.006\right)$. An interview with the ILO revealed that in order to ensure effective supervision by teachers, the polytechnic is giving a serious thought on introducing a checklist as a mechanism for regulating teacher supervision team in the near future. He indicates that not all but some selected teachers are mandated to supervise internship because of budget constraint. 
Table 4.13 Views of stakeholders on supervision in student internship

\begin{tabular}{|c|c|c|c|c|c|c|c|c|}
\hline \multirow[b]{2}{*}{ Statement } & \multicolumn{2}{|c|}{$\begin{array}{l}\text { Students } \\
(N=143)\end{array}$} & \multicolumn{2}{|c|}{$\begin{array}{l}\text { Teachers } \\
(N=16)\end{array}$} & \multicolumn{2}{|c|}{$\begin{array}{l}\text { Industry } \\
(N=41)\end{array}$} & \multirow[b]{2}{*}{$X^{2}$} & \multirow[b]{2}{*}{ Sig. } \\
\hline & Mean & $S D$ & Mean & $S D$ & Mean & $S D$ & & \\
\hline $\begin{array}{l}\text { Teachers supervise students' } \\
\text { work }\end{array}$ & 4.4 & 0.86 & 4.6 & 0.50 & 3.7 & 1.12 & 25.49 & $0.0005^{*}$ \\
\hline Enough teacher supervision & 3.6 & 0.98 & 3.8 & 1.23 & 3.0 & 1.33 & 12.61 & $0.002^{*}$ \\
\hline $\begin{array}{l}\text { Proper supervision by industry } \\
\text { supervisor }\end{array}$ & 4.0 & 0.83 & 3.8 & 1.12 & 4.4 & 0.86 & 10.19 & $0.006^{*}$ \\
\hline
\end{tabular}

Note: rating scale: 1 , strongly disagree; 2 , disagree; 3 , neutral; 4 , agree; 5 , strongly agree; SD, standard deviation; ${ }^{*} p<0.05$.

\section{Students' assessment of industry contribution}

Table 4.14 examines the students' satisfaction toward industry contribution to internship. Contrary to the report made by students in the context and needs assessment regarding industry personnel unfriendly relationship and unwillingness to teach students (Akomaning et al., 2011), in this study the means are between 4.2 and 4.6 with standard deviations in the magnitude of 0.49 and 0.71. This suggests that students are homogenous in their expression of contentment with assistance, willingness of industry staff to teach and collaboration with industrial workers. In response to the question of sections where students served, the researcher realises that of 89 interns visited, majority $(88 \%)$ of them served in at least three sections in the hotel industry and were assigned meaningful and challenging work. In the previous study students complained about serving in only one section in the entire internship period.

Table 4.14 Students' assessment of industry contribution to internship ( $N=143)$

\begin{tabular}{lcc} 
Statement & Mean & Std. Dev. \\
Benefited a lot from recent internship & 4.5 & 0.71 \\
\hline Industry workers were helpful & 4.3 & 0.63 \\
\hline Taught by workers of industry & 4.2 & 0.71 \\
\hline Learn to work with other workers in industry & 4.6 & 0.49
\end{tabular}

Note: $\quad$ rating scale: 1 , strongly disagree; 2 , disagree; 3 , neutral; 4 , agree; 5 , strongly agree.

\section{Duration and participation}

The context and needs study reveals that about $50 \%$ of the students spent four weeks out of a three-month mandatory internship period by the polytechnic (Akomaning et al., 2011). In this study evidence from student questionnaire data shows majority $(73 \%)$ of the students spent between eight and ten weeks whilst 16 
percent could fulfil a three-month mandatory period. Moreover, all the students had placements for internship. In the context and needs study about 20 percent of the students could not go on internship due to limited number of placements. With regard to duration and placement, it appears there have been some improvements. Nevertheless, these improvements could not be directly attributable to the use of the curriculum materials. It could be due to the gradual improvement in the relationship between the polytechnic and industry as interview with ILO connotes. Self-seeking option for placement is also adopted by the polytechnic. However the polytechnic provides assistance for students who face difficulty in this area.

\subsection{CONCLUSION AND DISCUSSION}

This article has looked at improved student internship in the Department of HCIM, the Takoradi Polytechnic in Ghana. This study has focused on collaborative design of curriculum materials by teacher teams, with input made by students and industry representatives, which were used during student internship to address the implementation challenges. The teachers, by their training and experience, in the design process of the curriculum materials ensured quality in terms of consistency, practicality and effectiveness. In other words, the contents of materials are said to be relevant and coherent and accepted by all stakeholders for the 2010 internship. Teachers, students and industry personnel concurred with the practical usefulness of the curriculum materials in the training of students. The subsequent outcomes of student self-assessed competencies and industry-based assessment appear to be commendable. Stakeholders acknowledge the curriculum materials serve as a guide to students' training, providing prior knowledge to both industry and students as to what roles are expected of them. Internship practices have improved in the areas of supervision, workers cooperating with interns, job rotation, and work assigned to interns. Other significant improvements, which include duration for internship, placement and participation of interns could however be traced to the improvement in the polytechnic-industry link/relationship.

The collaboration among teachers, with input from students and industry, in the design of the curriculum materials and the support of the polytechnic has had positive effects on the organisation of internship culminating in improved 
internship practices and student competencies. This study is comparable to that of Cecil et al. (2010) who contend that stakeholders are fairly satisfied with the curriculum designed to improve student competencies because stakeholders have their roles defined and the material is equally usable. Another study by Ko (2008) in which stakeholders' contribution to the hospitality internship curriculum gave rise to interns' satisfaction with the internships and the curriculum perceived as practical and useful is in consonant with this study. This research shows that teachers are also satisfied with the polytechnic making prior contacts with industry before students are sent out for internship but students hold a contrary view. Notably, the role of a teacher in the design and use of a curriculum material regardless of where it is applied cannot be overemphasised. If it will cost the polytechnic so much funds it cannot bear, it can device other alternative ways of ensuring a form of monitoring without necessarily visiting industry. Generally, there has been improvement on the part of all stakeholders. However, the polytechnic should endeavour to enrol more teachers on the internship supervision team and should continue to improve on its collaboration with industry. 


\title{
CHAPTER 5
}

\section{Towards sustainable student internship practices in Ghanaian Polytechnics: The impact of collaborative curriculum design}

\begin{abstract}
The study seeks to investigate the extent to which collaborative curriculum design (CCD) employed in designing curriculum materials for student internship in two polytechnics in Ghana have led to sustained improvement of student internship according to various stakeholders. It explores the impact of the curriculum materials on the organisation of internship and the challenges students face during internship. Finally, it examines the opinions of teachers and management representatives of the polytechnics on continued CCD to improve curriculum in the polytechnics.
\end{abstract}

\subsection{INTRODUCTION}

Stakeholders of education have expressed their views at various conferences on the continuation of educational innovations in institutions of higher learning (McCuddy \& Pirie, 2007) because promising educational reforms oftentimes do not go beyond the implementation phase (Fullan, 2007). Datnow and Stringfield (2000) contend that less than $50 \%$ of an initial successful implementation of educational innovation projects could be sustained beyond implementation. It is in the light of this challenge of sustainability that this study was carried out to ascertain the extent to which the renewed student internship in two polytechnics in Ghana were sustained. In an attempt to solve student internship challenges (Akomaning, et al., 2011), teachers in the Departments of Hotel Catering and Institutional Management (HCIM) of Tamale and Takoradi Polytechnics collaborated in teams to design curriculum materials having factored in input made by other stakeholders (industry personnel and students) of the HCIM programme to help guide student internship. In the process of designing the curriculum materials, the 
teachers took cognisance of the student and the environment (i.e., industry where student did internship) (Darling-Hammond \& Snyder, 1992) so that during internship the student is guided (by an industry based-supervisor) through the use of the curriculum materials but not controlled. The focus of this study refers to the effects of collaborative curriculum design (CCD) on the curriculum materials and the organisation of student internship in Tamale and Takoradi Polytechnics after adoption and implementation of the curriculum materials during 2009 and 2010 student internships respectively. Collaborative curriculum design could be explained in this study as a group of at least two teachers who collaboratively design or (re)design curriculum materials (Handelzalts, 2009) with the ulterior motive of improving student internship having solicited input from other stakeholders like students and industry personnel.

\subsection{THEORETICAL UNDERPINNINGS}

\subsubsection{Curriculum contributing to improved student internship practices}

Learning through participating in work can be understood in terms of how the workplace support or inhibit individuals' engagement in work activities and access to guidance (Billett, 2001). Internship is an educational strategy where learning in the classroom alternates with learning in the workplace and allows for the competencies of students to be developed and nurtured by the mentors before students graduate (Effah, 2005; Levesque et al., 2000). In order to fulfil the intended objectives of internships, internships need to be conceptualised more clearly as an integral part of the curriculum (Ko, 2008; Lee, 2007; Petrillose \& Montgomery, 1998; Tse, 2010) with authentic workplace learning environments (Blokhuis \& Nijhof, 2008) through which industry's contributions can be best organised to assist the learning required of the intern (Billett, 2006). Billett (2004) contends that participation, and therefore learning opportunities are not in fact unstructured and ad hoc but often highly regulated and structured. Lyons (2006) notes clear agreements concerning the roles and responsibilities of each party (teacher, student and industry personnel) are considered important.

There is an urgent need for internship curriculum practices because of the acknowledgement of the crucial role that internships play in individuals' initial learning and further development of vocational knowledge and skills throughout 
their working lives (Billett, 2006). The contributions made by teachers, students and industry personnel to the curriculum are of paramount importance because the practical use of such a curriculum will be fostered (Lee, 2007; Petrillose \& Montgomery, 1998; Tse, 2010). Therefore, the use of curriculum materials specifying what to be learnt and who is responsible for what could create a better platform for internship to be better organised. Hasbullah and Sulaiman (2002) assert that students' competencies improved remarkably through the use of curriculum materials for student internship after their industrial experience. They concluded students were prepared to enter into the world of work with confidence and ready to cooperate with employees having accomplished a guided internship. Without the identification, conceptualisation and acknowledgement of an internship curriculum, internships will remain misunderstood and delegitimised (Billett, 2006).

A cardinal constituent to making an internship programme stand out is job rotation. It permits interns to serve in the various sections of the organisation (industry) to gain practical experience in a range of activities (Gillim, 2006; Hasbullah \& Sulaiman, 2002) under supervisors as multiple mentors during internship (Kay \& DeVeau, 2003; Lam \& Ching, 2007). Articulating the responsibilities of interns and internship supervisors prior to the internship is a key element in a successful internship (Beggs et al., 2006).

Well-managed school-workplace collaboration could create an enabling environment for interns, teachers and industry personnel to appreciate and use the curriculum materials (Hasbullah \& Sulaiman, 2002) meant for student internship. The effective collaboration among the parties could give rise to joint interest, ambition and purpose towards a shared vision (Kliknaite, 2009; Pertuzẻ et al., 2010). It is equally important to ascertain that activities carried out by interns offer them the opportunity for professional growth within an organisation through the completion of challenging and meaningful work (Dixon et al., 2005; Ko, 2008). Another ingredient which should be taken into account during internship is the working relationship between the intern and the staff/workers of the industry. A friendly and helpful workplace where an intern would not feel like intruding on another's territory and where the intern is treated with the same respect as any employee (Dixon et al., 2005) could guarantee a successful internship. 


\subsubsection{The potential of collaborative curriculum design for curriculum improvement}

Possible sustainability of CCD thrives on some reasons for which the teacher's involvement in the entire change process cannot be overemphasised. Carlgren (1999) and Friedman (1997) argue that development of curriculum materials should not be seen as something teachers do in addition to teaching but as an integral part of the teacher's role. As teachers are the source of stability and change in schools, their role must be more closely considered in the process of any educational reform (Clandinin \& Connelly, 1992). Harris (2005) asserts that the failure of many reform efforts resides in their inability to involve the teachers as partners in the process of change.

The voluntary participation and expression of delight by teachers in design teams in a CCD endeavour is likely to lead to ownership (Erickson et al., 2005). CCD in design teams as a bottom-up approach relies on local initiatives of individuals or groups (Handelzalts, 2009). Collaboration in design of curriculum for student internship with the aim of improving student learning raises teachers' stakes in the process and the ownership of the product. Ownership serves as inspiration (Fullan, 2007) for teachers and other stakeholders to articulate the design of the curriculum.

Ongoing collaboration within a curriculum-focused team provides numerous opportunities for teachers to share their expertise (Sackney et al., 2005). Studies (Newmann \& Wehlage, 1995; Scribner et al., 2007; Weindling, 2005) on teacher teams indicates that change is more likely to be effective and enduring when those responsible for its implementation are included in a shared decision-making process on analysis and design of curriculum reform. Since stakeholders (teachers, students and industry personnel) are involved at the start of the design, it facilitates implementation of the improved curriculum because stakeholders who jointly contribute understand its contents (Ko, 2008). Hence increasing the sense of ownership of improved curriculum by the teachers and therefore increasing the quality of implementation (Johnson, 1993). However, in order to ensure sustainability of CCD as a means to curriculum improvement, there is the need to blend top-down provisions and bottom-up participation.

The quality of working relationships among teachers is strongly related to the quality of curriculum materials designed (Fullan, 2007). The extent to which 
individual teachers value cooperation and team membership where individuals delight in preference for group work, they are likely to interact more frequently, share information, and thus, learn more (Williams, Duray, \& Reddy, 2006). Teamwork may produce high levels of team commitment by promoting teacher collaboration among team members and facilitating the development of a shared vision as members in a collaborative endeavour (Postmes et al., 2001).

According to Reichstetter (2006) resource allocation would be made possible when teachers and management share a common vision focused on student learning and a commitment to improvement in curriculum. Sackney et al. (2005) contend teachers and management's perceptions on CCD in team's activities as essential because it generates coherence in the designed curriculum which results in curriculum improvement. CCD proposes better working conditions and better interrelationships amongst staff (Bascia, 2005; Durrant \& Holden, 2006). The extent to which individual members as well as team's needs, interests and goals are catered for would influence team members' opinions about CCD. Team members would be positive toward CCD if they are engaged purposefully in solving problems regarding curricular issues in their respective subject areas (Blankstein, 2004; Hirsh \& Killion, 2007). Hord and Sommers (2008) suggest that school management should provide the physical requirements to support collaboration, like, time, place for meeting, and policies supporting collaboration and eventual curriculum improvement. Management is vital in sustaining CCD to foster sustainable curriculum improvement by providing incentives and encouragement to the teams (Hirsh \& Killion, 2007; Karukstis \& Elgren, 2007).

The issue of sustainability of educational reforms is of grave concern to stakeholders of education because impressive projects hardly go beyond implementation (McCuddy \& Pirie, 2007). It is therefore vital to scrutinise conditions that foster or impede the continuation of educational reforms in order to take appropriate measures that would address the challenges having regard to the context because a promising innovation in one setting may not be successful in another. CCD as a strategy for designing curriculum is a way of empowering teachers, particularly at the tertiary education institution, to be curriculum makers (Darling-Hammond, \& Snyder, 1992) whereby the quality of their products and subsequent improvement in their application creates ownership (Erickson et al., 2005) and sustainability (Hirsh \& Killion, 2007; Karukstis \& Elgren, 2007). 


\subsection{PURPOSE OF THE STUDY}

The purpose of the study was to investigate the extent to which the Departments of HCIM at Tamale and Takoradi Polytechnics have continued with the activities of CCD to improve curriculum materials for student internship, and the influence of the curriculum materials on the organisation of student internship as well as the opinions of teachers and management on CCD. The main research question was formulated as: To what extent does collaborative curriculum design lead to sustainable student internship practices according to the various stakeholders? The following sub-questions guided the study:

1. How and why does CCD in design teams lead to improved curriculum materials for student internship according to teachers and management representatives?

2. How and why does the output of CCD, that is the curriculum materials for student internship, positively influence the organisation of student internship?

3. How and why does the output of CCD, that is curriculum materials, address the implementation challenges of student internship?

4. What are the opinions of teachers and management representatives to continue CCD in teams as a means for curriculum improvement?

\subsection{CONTEXT OF THE STUDY}

Hotel Catering and Institutional Management (HCIM)

The mandate of HCIM is to train students to managerial or supervisory position in the hospitality industry in Ghana. The HCIM programme is a three-year tertiary programme. The primary focus of the department is to prepare students not only with theory but with hands-on training so as to improve on their employability. To execute this assignment, internship programme forms an integral component of the HCIM programme. Throughout the entire 3-year programme, students are supposed to make at least six months internship. The internship placement period is carried out in two sessions. Each session covers a period of three months at the end of the first two academic years. These internship periods are expected to be supervised by both polytechnic educators and industry representatives. In order to smooth the progress of the internship programmes in the polytechnic, Industrial Liaison Unit (ILU) has been authorized to facilitate internships. 


\section{Tamale}

Tamale is the regional capital of the Northern Region of Ghana. The region is among four of the regions in Ghana classified as poor. It is sparsely populated, lacks infrastructure as well as industries. The HCIM department of Tamale Polytechnic is the focus of this study. Tamale Polytechnic commenced as a trade school in 1950 and in 1993 was elevated to a tertiary educational institution (PNDCL 321, 1992). The polytechnic is made up of three schools. These are Schools of Business, Engineering and Applied Science (Tamale Polytechnic, 2007). Each school constitutes departments. The Department of HCIM is one of the departments under the School of Applied Science. The polytechnic is the only one in the country which runs a technical institute alongside it. In order to facilitate the activities of the polytechnic, there are a number of offices/sections with specific mandates. The ILU is one of the offices with staff strength of two mandated to co-ordinate with organisations to enable students to have practical industrial experience in the various fields. The industrial liaison officer oversees to the organisation of student internship in the polytechnic. He prepares introduction letters and assessment forms for students who express interest in embarking on internship and he is supposed to assist both teaching staff and students regarding the polytechnic's link with industry (organisations). Students in the HCIM department generally have their internships in the restaurants, hotels and hospitals (kitchen/canteen department). The staff strength of this department is 10 and the student population is 118 .

\section{Takoradi}

The second study site is Takoradi which is located at the south-west part of Ghana. Takoradi is the regional capital of the Western Region of Ghana. The region is rich in natural resources and is densely populated. Takoradi is the third largest city in Ghana as well as the third industrialised city. It is brisk in its economic activities. The HCIM department in Takoradi Polytechnic is the focus of this study with staff strength of 22 and student population of 225. Takoradi Polytechnic was established in April 1954 as a Government Technical Institute. It was upgraded by the polytechnic law enacted on the $5^{\text {th }}$ of March 1993 to become part of the Ghana tertiary education system. In 1992/93 academic year, it started to offer Higher National Diploma (HND) programmes. Takoradi Polytechnic has four schools. These are Applied Science and Mathematics, Management/Business Studies, Applied Arts and Engineering. These schools constitute 16 academic departments of which the School of Applied Science and Mathematics is 
Department of HCIM. The institution's ILU which has staff strength of seven is very vibrant in regard to student internship.

\section{$5.5 \quad$ METHODS}

\subsubsection{Design of the study}

A multiple case study research design was employed for this study (Yin, 2003). Hartley (2004) explains case study research as a strategy appropriate for exploring a phenomenon which is not isolated from its context but is of interest precisely because the aim is to understand how behaviour and/or processes are influenced by context or vice versa. This study is akin to that in the sense that it involves teachers, management representatives, students and industry personnel whose perceptions about CCD in design teams and the products of the design teams (curriculum materials) are influenced by their contexts (or vice versa) at the polytechnics. Two contexts comprising Tamale Polytechnic and Takoradi Polytechnic in the Departments of HCIM were investigated during the study. Management representatives, teachers, students and industry personnel were the units of analysis. Both qualitative and quantitative data were collected.

\subsubsection{Participants}

Tamale

Eight teachers from Department of HCIM at Tamale Polytechnic took part in the study. All the teachers were part of the CCD and collaborated with team members in the designing of the curriculum materials for the 2009 student internship. Moreover, an industry liaison officer (ILO) and Vice Rector of Tamale Polytechnic hereafter referred to as polytechnic management representatives constitute part of the respondents. These persons were also part of the respondents at the commencement of the project (context and needs analysis). Management representatives were included in the study because of their role in student internship and more so could influence polytechnic management on policy decisions. Additionally, 75 students from the department and five hotel industry personnel participated in the study. These students and industry personnel contributed to the design of the curriculum materials and used them as internship guide during student internship in 2009. 


\section{Takoradi}

Fifteen out of the 16 teachers from the Department of HCIM, Takoradi Polytechnic who participated in CCD in the designing of the curriculum materials for student internship in 2010 took part in this study. Additionally, two industrial liaison officers (ILOs) and a Dean from the School of Applied Science (Department of HCIM is one of the departments of the School) all of Takoradi Polytechnic were part of the study and they are hereafter referred to as management representatives. It should be noted that they were all involved at the start of the project (the context and needs analysis). These persons were included because of their role in student internship and more so could influence polytechnic management on policy decisions. Besides, 132 students from the department and six hotel industry personnel took part in the study. These persons were involved at the start of the project (context and needs analysis) and contributed to the design of the curriculum materials which were used for the 2010 student internship.

\subsubsection{Research instruments}

Table 5.1 shows an overview of research instruments and constructs measured (see Appendix D). 
Table 5.1 Overview of research instruments and constructs addressed

\begin{tabular}{|c|c|c|c|c|}
\hline Instrument & $\begin{array}{l}\text { No. of } \\
\text { Items }\end{array}$ & Construct & Reliability & $\begin{array}{l}\text { Research } \\
\text { question }\end{array}$ \\
\hline $\begin{array}{l}\text { Teacher question- } \\
\text { naire: close-ended }\end{array}$ & 8 & Reasons affecting CCD & .75 & 1 \\
\hline Interview (Mgt rep) & $4(2)$ & $\begin{array}{l}\text { E.g., Shared expertise, creating } \\
\text { ownership }\end{array}$ & $\mathrm{N} / \mathrm{A}$ & 1 \\
\hline $\begin{array}{l}\text { Teacher question- } \\
\text { naire: close-ended }\end{array}$ & 4 & Influence of curriculum materials & .90 & 2 \\
\hline Interview (Mgt rep) & $5(4)$ & $\begin{array}{l}\text { E.g., Roles of participants in } \\
\text { internship }\end{array}$ & N/A & 2 \\
\hline $\begin{array}{l}\text { Student question- } \\
\text { naire: close-ended }\end{array}$ & 4 & Influence of curriculum materials & .83 & 2 \\
\hline open-ended & 2 & Use of curriculum materials & $\mathrm{N} / \mathrm{A}$ & 2 \\
\hline $\begin{array}{l}\text { Focus group } \\
\text { interviews }\end{array}$ & 1 & Use of curriculum materials & N/A & 2 \\
\hline $\begin{array}{l}\text { Teacher question- } \\
\text { naire: close-ended }\end{array}$ & 6 & $\begin{array}{l}\text { Addressing internship challenges } \\
\text { through curriculum materials }\end{array}$ & .56 & 3 \\
\hline Interview (Mgt rep) & 3 & $\begin{array}{l}\text { E.g., Lack of job rotation, lack of } \\
\text { supervision during internship }\end{array}$ & N/A & 3 \\
\hline $\begin{array}{l}\text { Student question- } \\
\text { naire: close-ended }\end{array}$ & 6 & $\begin{array}{l}\text { Addressing internship challenges } \\
\text { through curriculum materials }\end{array}$ & .75 & 3 \\
\hline open-ended & 2 & & $\mathrm{~N} / \mathrm{A}$ & 3 \\
\hline $\begin{array}{l}\text { Focus group } \\
\text { interviews }\end{array}$ & 6 & $\begin{array}{l}\text { Resolution of implementation } \\
\text { challenges }\end{array}$ & N/A & 3 \\
\hline $\begin{array}{l}\text { Teacher question- } \\
\text { naire: close-ended }\end{array}$ & 7 & $\begin{array}{l}\text { Opinions toward CCD as means } \\
\text { to improve curriculum }\end{array}$ & .80 & 4 \\
\hline Interview (Mgt rep) & $5(4)$ & $\begin{array}{l}\text { E.g., Benefits of Shared expertise, } \\
\text { facilitates implementation, } \\
\text { management support }\end{array}$ & N/A & 4 \\
\hline \multirow[t]{2}{*}{ Industry interview } & 5 & $\begin{array}{l}\text { E.g., Roles of participants in } \\
\text { internship }\end{array}$ & N/A & 2 \\
\hline & 3 & $\begin{array}{l}\text { E.g., Lack of job rotation, lack of } \\
\text { supervision during internship }\end{array}$ & N/A & 3 \\
\hline
\end{tabular}

Note: Mgt rep, Management representative; N/A, Not applicable.

Teacher and Management representative instruments: Teacher instruments composed of a questionnaire and interviews. The former consisted of close-ended question items on a five-point Likert scale using responses graded: 1 strongly disagree and 5 strongly agree to determine the level of agreement to the statements. The interviews were structured. Teachers' questionnaire and interviews centred on influence of CCD to improved curriculum materials, the effect of the curriculum materials on the organisation of internship, on addressing implementation challenges and teachers' opinions toward $\mathrm{CCD}$ as a means to curriculum 
improvement. Management representative's interviews covered the same topics (see Appendices D1and D2).

Student instruments: Student instruments consisted of a questionnaire and focus group interviews. The questionnaire administered to students comprised closeended statements and open-ended questions. The first part captured year group, gender, name of organisation of the 2010 internship and duration of the internship. The close-ended question items had responses on a five-point Likert scale graded: 1 strongly disagree to 5 strongly agree to determine the level of agreement to statements. These statements focused on influence and use of curriculum materials on organisation of internship, and addressing internship challenges through curriculum materials. The open-ended questions and the focus group interviews centred on addressing internship challenges and the usefulness of curriculum materials (see Appendices D3 and D4).

Industry personnel's interview: Industry personnel's interview centred on the usefulness of the curriculum materials on the organisation of internship and the resolution of implementation challenges through the curriculum materials (see Appendix D5).

\subsubsection{Data analysis}

Data were analysed qualitatively and quantitatively. Data from questionnaires were analysed using SPSS. Descriptives were used to determine the teachers' reasons for $\mathrm{CCD}$ to improve curriculum materials, to address the implementation challenges and to determine differences in the perceptions of influence of the curriculum materials on the organisation of student internship between the teachers of Takoradi and Tamale. Chi-square test was used to determine the mean differences between the students of Takoradi and Tamale on the use and influence of the curriculum materials on the organisation of internship as well as addressing the implementation challenges of internship.

All interviews were transcribed and coded using codes generated from the study and labelled under coding themes (Bogdan \& Biklen, 1992; Miles \& Huberman, 1994). Examples of deductive codes were shared expertise and creating ownership and examples of inductive codes were feedback for improvement and coherence in curriculum objectives which partly address research question 1. Teacher internship role and expected direction to internship are deductive codes that partly answer 
research question 2. Atlas-ti software version 6.2 was used for the coding of all the interview data. Intercoder reliability (Lombard et al., 2002; Neuendorf, 2002) was calculated using a random sample of 10 interviews from 23 teachers, and six interviews from 11 industry personnel. There were two coders including the researcher. The intercoder reliability using Cohen's kappa $(\mathrm{k})$ were 0.86 for teachers and 0.89 for industry personnel.

\subsection{RESULTS}

Research question 1 explores curriculum design as part of teachers' role, shared vision on curriculum goals and organisation, creating ownership and shared expertise whose fulfilment are contingent upon the conditions of teacher value for teamwork and the promotion of teacher collaboration in design teams. Table 5.2 shows teachers' responses to reasons why teachers collaborate in teams to design improved curriculum materials for student internship. The teachers from both polytechnics highly appreciated working in teams with colleagues (Mean range for Takoradi 4.5 to 4.7 and 4.4 to 4.8 for Tamale).

Table 5.2 Reasons for engaging in CCD as reported by teachers

\begin{tabular}{|c|c|c|c|c|}
\hline \multirow[b]{2}{*}{ Working in teams } & \multicolumn{2}{|c|}{ Takoradi $(N=15)$} & \multicolumn{2}{|c|}{ Tamale $(N=8)$} \\
\hline & Mean & Std. Dev. & Mean & Std. Dev. \\
\hline Delight in active involvement with other teachers & 4.5 & .64 & 4.8 & .46 \\
\hline $\begin{array}{l}\text { I prefer design of curriculum materials with other } \\
\text { teachers. }\end{array}$ & 4.5 & .74 & 4.6 & .52 \\
\hline $\begin{array}{l}\text { Cooperation with other teachers in designing } \\
\text { curriculum materials to improve internship }\end{array}$ & 4.5 & .52 & 4.8 & .46 \\
\hline $\begin{array}{l}\text { Learning from other teachers when designing } \\
\text { curriculum materials }\end{array}$ & 4.6 & .51 & 4.6 & .52 \\
\hline $\begin{array}{l}\text { Continuation of teacher collaboration of designing } \\
\text { curriculum materials }\end{array}$ & 4.7 & .62 & 4.4 & .52 \\
\hline \multicolumn{5}{|l|}{ Quality curriculum materials } \\
\hline $\begin{array}{l}\text { Improved curriculum materials for internship through } \\
\text { CDD }\end{array}$ & 4.5 & .64 & 4.8 & .46 \\
\hline $\begin{array}{l}\text { Curricula prepared by teachers can guarantee } \\
\text { successful implementation }\end{array}$ & 4.3 & .90 & 4.6 & .52 \\
\hline $\begin{array}{l}\text { Encouragement of ownership of curriculum materials } \\
\text { for internship }\end{array}$ & 4.5 & .75 & 4.5 & .52 \\
\hline
\end{tabular}

Note: rating scale: 1 , strongly disagree; 2 , disagree; 3 , neutral; 4 , agree; 5 , strongly agree. 
The approach (CCD) catered for improved curriculum materials in both institutions with mean range between 4.3 and 4.5 for Takoradi and 4.5 and 4.8 for Tamale. Only the teachers from Takoradi seemed to differ in their ideas about the statement Curricula prepared by teachers can guarantee successful implementation, given the fairly high standard deviation $(\mathrm{SD}=0.90)$. Tamale and Takoradi unanimously embraced $\mathrm{CCD}$ as a means to improve curriculum materials for internship.

To further understand why the teachers would consider curriculum design as part of their role, based on the interview data all the respondents in both institutions were positive. Three reasons featured prominently in the responses of teachers for considering curriculum design as part of their role. These were as follows: (i) the polytechnic as a tertiary institution should be given the mandate to design its own curriculum, (ii) teachers are conversant with the polytechnic system and industry hence could guarantee quality of curriculum and (iii) teachers have the professional expertise to design curriculum. They admitted that designing of the curriculum would mean extra work but worth undertaking. The design of curriculum as part of teachers' role is well expressed by a teacher from Takoradi who said, "Yes, because with our experience in curriculum development and industry as polytechnic lecturers it would further improve on our professional competence. The polytechnics should be given the chance to develop our own curriculum like the universities" (Teacher interview). Similarly a management representative of Tamale said, "Yes, because the polytechnic is a tertiary institution and it would be appropriate for teachers to develop their own curriculum as the universities. It is something polytechnics will be happy about because we want independence. This is the type of independence where we can design curricula on our own and do everything that will ensure independence even though that would mean that we have to be more responsible than before" (Management representative interview).

In reacting to the question Do you still see activities of CCD as relevant means for improved curriculum materials for student internship? all teachers interviewed from Takoradi expressed CCD in design teams was very relevant because it leads to shared expertise. Teachers were able to share their experiences in their subject content domains as well as in industry with colleagues that would improve the curriculum materials for student internship. A comment from a teacher from Takoradi is an example, "Teachers have different industrial experiences. So, when we meet as a team such experiences are shared and deliberated upon in CCD and what may be good for our students are recommended and incorporated in the curriculum". Statements 
made by two of the Tamale teachers typify the improvement of curriculum materials as teachers share their expertise in teams: "Assembling of ideas from various teachers makes the output richer (curriculum materials) than from one person". "Because during CCD in design teams we put our ideas together and eventually select the best way out thereby improving curriculum as well as teaching and learning". The interviews from management representatives of both institutions were in consonant with the teachers. A comment from a management representative from Takoradi was as follows: "Yes, because when the team come together, they become a source of information. Teachers will bring all relevant materials in order to ascertain a curriculum material for the purpose for which CCD in design teams may be formed". His fellow counterpart in Tamale said, "There is some sort of awakening; the curriculum material is not done by one person, you have different shades of ideas of how things should work. It also provides a laid down procedures for students to follow".

In advancing the essence of CCD in design teams, 10 of the 15 Takoradi teachers claimed the continued collaboration in teams charged with improving curriculum materials as well as improving student learning through student internship creates ownership. It is of importance to note that Takoradi teachers (working in teams) were committed to a department-initiative internship which was quite different from the general summer break internship organised by the polytechnic for all departments. The department-initiative internship termed by the department (HCIM) as a weekly internship was instituted with the support of the polytechnic with the ultimate aim of ensuring improved student internship. It could be inferred that teachers were partly motivated by the creation of ownership of CCD which in turn committed them to the weekly internship. In support of this claim, two teachers said, "I am also involved in the weekly industrial attachment where we assign students to various hospitality facilities in and around the metropolis (Takoradi). We discuss with industry personnel concerning the conduct of students. Sometimes we share ideas with industry about the operations of industry". "For the weekly industrial practice that we have in the department, lecturers go round to actually mark the students on the job whereby in a way it has really enhanced curriculum materials as well as industrial attachment". Thus the weekly internship created much more space and time for Takoradi teachers to be more involved in student internship. No such claim on ownership was made by Tamale teachers which could imply that Tamale was less involved in CCD activities. This could be supported by four of the eight teachers being hesitant about CCD activities carried out in the polytechnic. However, one of the management representatives of Tamale saw ownership as key. He disclosed, "If the level of commitment is high it means the outcome or the 
output is likely to be of high quality. That apart I would say these are key stakeholders that come out with something and therefore ownership is for them and instead of something that is coming from outside and being imposed upon them. It is something they own".

In emphasising CCD in design teams as a means to improve curriculum materials, five Takoradi teachers realised that teachers continued collaboration leads to shared vision on curriculum goals and organisation. One clear example is that Takoradi teachers with the support of polytechnic management have come up with a weekly internship in 2008 which is quite distinctive from the usual summer break internship common to all polytechnics in Ghana. "CCD is very good; teachers getting together to share ideas on pertinent issues bordering on student learning. Individually we may be facing some challenges but when we come together as a design team we all bring these challenges out and then we are able to deliberate and know how best to fix them with the ultimate aim of helping to improve on curriculum materials for student learning", was a response made by one of the teachers from Takoradi. The only comment on shared vision on curriculum goals and organisation from a Tamale teacher was as follows: "CCD is a collective vision or effort rather than one person, hence the likelihood of the products (curriculum materials) being of quality and implementation becomes easier". In firming up this position, a management representative from Takoradi said, "With regard to industrial attachment, the object of organising is for students to complement the theory learnt on campus with practical skills. So with CCD in design teams if the purpose is to improve curriculum materials for student industrial attachment, teachers will make sure of achieving those objectives of improvement by consensus". His Tamale counterpart concluded by remarking, "Teachers are needed for industrial attachment they teach the students in the classroom and with their experience in industry can assess what is practised in the industry. So, the existence of CCD in design teams will enhance the curriculum materials for the organisation of internship".

The new emerging constructs from respondents on the relevance of teachers engaging in CCD were feedback for continuous improvement in curriculum and coherence in curriculum objectives. Two teachers each from Takoradi and Tamale identified feedback from stakeholders like students and industry personnel as a way of improving curriculum materials. A statement made by a teacher from Takoradi corroborates this assertion: "The whole idea of CCD in design team is continuous improvement of the curriculum materials. And if you want to improve, then, you must fall on the feedback you get from stakeholders on whatever you are doing". In respect of feedback a Tamale teacher states: "So when students come back from 
internship, and they are giving the feedback to the teachers; such teachers based on the feedback develop a policy which will naturally be based on what the students have complained of and those factors will be part of the items to be considered in the CCD. So I think that the coming together for teachers to design is probably the best form". Five Takoradi teachers recognized that CCD was relevance because it promotes coherence in curriculum objectives. Thus as teachers collaborate in teams to develop curriculum materials with input from other stakeholders like students and industry personnel, curricular objectives are harmonised. That is, within the context of hospitality industry for which the curriculum is intended. A teacher's remarks worth considering: "Teachers know what the industry is looking up for and if we are able to design a format for industry and students, during industrial attachment, industry will try to help students achieve the instructional objectives".

Teacher value teamwork and promotion of teacher collaboration are conditions under which improvement in curriculum materials could be guaranteed. Six Takoradi teachers and one Tamale teacher pointed out teacher value teamwork as condition that fosters improvement in curriculum materials for student internship. A comment from a Takoradi teacher on teacher value teamwork is: "The motivating factor is the desire for teachers to get together to help improve curriculum materials for student internship so that students will be able to acquire the necessary skills". Her counterpart in Tamale reported as follows: "So it is very good to sit together to deliberate on issues on curriculum materials. By so doing it makes the teacher's work very easy and simple because two heads are better than one". With respect to promotion of teacher collaboration; six Takoradi teachers, three Tamale teachers and one management representative from Takoradi revealed that promotion of teacher collaboration is key to successful improvement in curriculum materials for student internship. A statement made by a teacher from Takoradi is, "Because it helps teachers to know and to discuss what goes on in the different course areas. CCD helps teachers to relate with one another thereby enhancing the content knowledge of individual teachers". A counterpart's comment was as follows: "The ability for teachers to come together to share views on issues through such sharing of ideas teachers tend to learn from each other in the team". The only comment from management representative was from Takoradi: "The motivating factor in the maintenance of CCD in design teams is cooperation among teachers".

In conclusion, teachers from both Takoradi and Tamale were very positive on $\mathrm{CCD}$ as a means to improved curriculum materials as evidenced in the high mean scores on working in teams and quality curriculum materials. The interview data 
from teachers and management representatives further buttressed the quantitative data from teachers. Teachers and management representatives acknowledge curriculum development as part of teacher's role particularly in tertiary educational institutions like the polytechnic. It was identified that CCD in design teams gives rise to shared expertise among teachers, creates ownership, and shared vision on curriculum goals and organisation. However, Tamale teachers and Takoradi management representatives did not identify CCD as creating ownership. The possible explanation for the former could be that Tamale teachers were not actively involved in student internship. Other constructs not identified in the conceptual framework but emerged from data that could improve curriculum materials were feedback for continuous curriculum improvement and coherence in curriculum objectives as a result of liaising with other stakeholders like students and industry. All such constructs that could improve curriculum materials for student internship are premised on conditions where teachers would value working in teams and institutional support for CCD in design teams.

Research question 2 examines the positive influence of the curriculum materials on the organisation of student internship. In this vein, the views on the roles played by students, teachers, management representatives and industry personnel were investigated as well as the eventual student learning culminating in improvement in competencies.

\subsubsection{Teacher perspective on influence of curriculum materials}

The influence of curriculum materials on the organisation of student internship from the perspectives of the teachers is presented in Table 5.3. The mean range of teachers from Takoradi (3.9-4.5) was higher than that of Tamale (3.4-3.9) implying that Takoradi teachers perceived Student competencies have improved ever since the curriculum materials were used by students as the most influenced by the curriculum materials. On the contrary, the teachers perceived Hospitality industry supervision of students has improved was the least influenced by the curriculum materials. Takoradi teachers' perception on the influence of the curriculum materials on Teacher supervision of students on internship has improved (Mean=4.3) was much higher than Tamale (Mean=3.4). So, the higher means of Takoradi teachers connote that the impact of the curriculum materials had improved internship practices in Takoradi Polytechnic more than in Tamale Polytechnic. A possible explanation of these differences was that Takoradi teachers were more involved in the implementation of student internship than Tamale and therefore had a 
better understanding of the positive influence of the curriculum on internship. The relatively high standard deviations of 1.06 further demonstrate that Tamale teachers seemed to differ in their perceptions about all the statements except on improvement on student competencies $(\mathrm{SD}=0.64)$.

Table 5.3 Teachers' views on the influence of curriculum materials for student internship

\begin{tabular}{lccccc} 
& \multicolumn{2}{c}{ Takoradi $(\mathrm{N}=15)$} & \multicolumn{2}{c}{ Tamale $(\mathrm{N}=8)$} \\
\cline { 2 - 5 } & Mean & $\begin{array}{c}\text { Std. } \\
\text { Dev. }\end{array}$ & Mean & $\begin{array}{c}\text { Std. } \\
\text { Dev. }\end{array}$ \\
$\begin{array}{l}\text { Statement } \\
\begin{array}{l}\text { Teacher supervision of students on internship has } \\
\text { improved }\end{array}\end{array}$ & 4.3 & 0.80 & 3.4 & 1.06 \\
$\begin{array}{l}\text { Teacher involvement in student internship has } \\
\text { improved }\end{array}$ & 4.1 & 1.06 & 3.6 & 1.06 \\
$\begin{array}{l}\text { Hospitality industry supervision of students has } \\
\text { improved }\end{array}$ & 3.9 & 0.96 & 3.4 & 1.06 \\
$\begin{array}{l}\text { Student competencies have improved ever since the } \\
\text { curriculum materials were used by students }\end{array}$ & 4.5 & 0.64 & 3.9 & 0.64
\end{tabular}

Note: rating scale: 1 , strongly disagree; 2 , disagree; 3 , neutral; 4 , agree; 5 , strongly agree.

Responding to the interview question for teachers Are the curriculum materials designed for student internship being used by students? All the teachers from Takoradi Polytechnic except two disclosed that the curriculum materials designed collaboratively by the design teams were used by the students during student internship. The two others were not sure of their use by the students. Seven out of eight teachers from Tamale assert the curriculum materials collaboratively designed by the design teams were used by students during the 2010 internship.

To further advance the reasons why teachers perceived stakeholders would use the curriculum materials, nine out of the 15 Takoradi teachers interviewed expressed that the curriculum materials had given direction to the organisation of student internship in the sense that the teachers, students and industry personnel were fully aware of what to do. Three of the teachers could infer from the improvement in students' comprehensive reports as improvement in organisation of student internship which could be partly attributed to the use of the curriculum materials by students and industry. "We realised that initially industry personnel were doing whatever they like. They didn't even have job specification for our students. But now they know what is expected of them and they know what the students are expected to go through," stated by a Takoradi teacher. In firming up this argument from inference of students' reports, another teacher from Takoradi said, "When 
you mark students' reports on industrial attachment, one will realise that there is improvement. Now students are more interested in industrial attachment and recommendation and conclusions of students' reports suggest drastic improvements as compared to previous reports. Students commend management of industry for allowing them to carry out some duties they were not permitted previously".

Tamale teachers explained the curriculum materials were used as a guide to the organisation of the internship which had contributed to improvement in students' practical skills. To support the stance one of the teachers from Tamale indicated, "I think these (curriculum materials) have contributed to their (students) interest and zeal to do the industrial attachment. Now students are seen by teachers as being serious toward attachment which could stem from the curriculum materials".

To further assess the positive influence of the curriculum materials, these are responses to teacher interview question How have the curriculum materials designed by the design teams influenced student internship? five of the Takoradi teachers expressed that the curriculum materials had promoted job description where the expected roles of students, teachers and industry personnel were specified. Four of the teachers indicated that the introduction of the curriculum materials had created awareness and seriousness on the part of students during internship and industry workers had better understanding about interns. Two each (Takoradi) state that the curriculum materials had improved the writing skills of students (from the reports assessed by students) and improvement in students' practical lessons on-campus after the internship which they attributed it to the curriculum materials. A Takoradi teacher articulates the roles of industry personnel and interns in the recent student internship (2010) as, "Now that students have the curriculum material, they know exactly what they are supposed to do, what they are supposed to learn and the supervisors and managers in industry too know what they are supposed to teach the students so it is not a matter of teaching them anything that is not relevant. Things taught students are relevant and that is what industrial attachment is meant for".

Another argument presented by a Takoradi teacher on improved relationship between interns and industry workers during internship was as following: "It (curriculum material) has actually influenced student industrial attachment because now they (students) know what is expected of them. Students are now abreast with what to expect during industrial attachment. The hitherto unfriendly attitude of industry personnel which was characterised by fear has changed because interns are not seen as threats". 
Four of the Tamale teachers assert that the curriculum materials served as a source of guide to the organisation of internship spelling out the distinctive functions of the students and industry personnel and thereby enhancing job rotation. Three teachers disclosed the curriculum materials had created the awareness and importance of internship in students which in turn had whipped up the interest of students toward internship. A claim made by a teacher from Tamale which is worth stating: "The curriculum material has influenced student internship positively because previously students had no guide hence industrial attachment was quite haphazard in its organisation (students and industry did not know what to do) but now there has been improvement e.g. students are not kept in one section of the hospitality industry and practical skills students are expected to acquire".

Another position which was communicated by teachers on the influence of the curriculum materials on the organisation of student internship was improvement in competencies of students. From the interview question In which ways do you think the curriculum materials influenced student competencies during and after the 2010 student internship? 14 out of 15 Takoradi teachers stated that the curriculum materials had positive impact on the practical skills of students which were demonstrable after the internship during lecturing and practical lessons oncampus. They expressed that the observed as students' drastic improvement in the various disciplines in the hospitality management programme. Specific mentions were made in the areas of food production and housekeeping where students were able to identify and appropriately use equipment and machines. Two of the teachers indicated that students worked with little supervision and attributed the improvement in practical skills to the organisation of internship guided by the curriculum materials. "...Confidence with which students approach their practical lessons is an indication of positive influence of curriculum material on student competencies," remarked one of the teachers. The only Takoradi teacher who was ambivalent on the influence of the curriculum materials on student competencies did not teach practical lessons in the four main domains of hospitality management programme.

In Tamale on the other hand seven out the eight teachers expressed that students who took part in the 2010 internship had improved on their practical skills which could be partly attributed to the use of the curriculum materials. Students (particularly those who participated in 2010 internship) improved considerably on their practical skills during practical lessons on campus after the internship, especially in the areas of food production and housekeeping sections of the 
hospitality management programme. A teacher further indicates improvement in communication skills of interns. "I can't tell because I did not go to supervise students during industrial attachment", remarked the only Tamale teacher who was hesitant in alluding to the influence of the curriculum materials on student competencies.

The views expressed by polytechnic management representatives were in consonance with teachers regarding the influence of curriculum materials for student internship. Four out of five management representatives claim the curriculum materials were used as a guide to student internship. The only exception was from Tamale who indicated he could not supervise the students while on internship. However, a position made by a management representative (from Tamale) on the influence of curriculum materials was as follows: "I would answer it by saying that indirectly 'yes'. Because I have visited a number of hotels myself when making booking for congregations for this polytechnic I meet my own students and have a chat with them and I interview and they are happy. Formerly I don't think that level of happiness or closeness to industry was achieved. I will say that it is an indirect impact of the intervention (curriculum materials). I would say 'yes' because with that students will know exactly what is expected from them. They know what they have to go through. Industry also knows that there is a guide and will know how to help our students".

\subsubsection{Industry perspective on influence of curriculum materials}

In responding to the interview question Are the curriculum materials designed for student internship being used by students and would you advise the use of them for future student internship? All the hospitality industry personnel acknowledge the use of the curriculum materials by the students during the 2010 internship and recommended their use in future internship. All the hospitality industry personnel unanimously concurred that the curriculum materials were a guide to all stakeholders particularly students and industry personnel. Moreover, six out of the 11 personnel indicated that the curriculum materials specified the roles of students, teachers and industry personnel. As reference document, four explained that the use of the curriculum materials had improved student performance. As disclosed by one of the industry personnel regarding the influence of the curriculum materials on organisation of student internship: "The curriculum materials are a very useful guide which help both the students and industry. The curriculum materials are being designed in such a manner that they are easy to follow accordingly and it reduces the burden on the industry and students. They make the attachment process very easy and smooth; spelling out what students and industry are supposed to do". 
In answering the interview question, In which ways do you think the curriculum materials influenced student competencies during the 2010 student internship? All of the 11 industry personnel explained the curriculum materials influenced the practical skills of students because the documents were followed by both industry and students. Three of the personnel expressed seriousness on the part of students because the curriculum materials specify students should be given the opportunity to serve in all the sections of the hospitality industry. A hotel manager advocates the use of the curriculum materials because they were a guide to both students and industry. He explained, "For 2010 I will say the influence was positive and I would advise that the curriculum material will be used because now students have a documented guide previously there was no such guide. Naturally the students have something that they are abiding by and also as managers we were given copies which we studied and tried to work accordingly".

Another industry manager articulates the curriculum materials specify the roles of students and industry resulting in improvement in competencies. He put it as, "This curriculum material puts students on their toes and they know exactly what to expect and what to do. So any student who comes on an attachment knows what he/she is supposed to be doing in the industry. So it influences their skills and competencies in the various sections in the hotel industry e.g. how to receive a guest, lay bed; serve a guest, calculation of the vat receipts".

In spite of the positive influence of the curriculum materials on the organisation of student internship, two hotel industry managers from Tamale complained about Tamale Polytechnic to be more proactive in student internship by ensuring that many more students got involved in the internship programme. This complaint is supported by a comment made by one of them: "Reading through curriculum materials I saw that they are of use to the student, teacher and industry. The design teams were involved in the curriculum designed so once teachers are aware of its composition I think now the time has come for the Department of HCIM to be resourced in order to be proactive in student industrial attachment. By so doing all stakeholders will benefit".

\subsubsection{Student perspective on influence of curriculum materials}

Table 5.4 depicts the influence of the curriculum materials on student internship from the perspectives of the students. With the exception of improvement in competencies of students ever since the curriculum materials were used where there was no significant difference between the students of Takoradi and Tamale all the 
other variables were significant. Nevertheless, this variable recorded the highest mean score of 4.1 for both Takoradi and Tamale. For instance, the mean scores of Takoradi (Mean=3.9, $\mathrm{SD}=0.90)$ and Tamale $(\mathrm{M}=2.7, \mathrm{SD}=1.23)$ students on the variable Teacher supervision of students on internship has improved, there was significant difference between them, $X^{2}=64.37, p=.0005$. The mean scores on the variable Hospitality industry supervision of students has improved, Takoradi (Mean=4.0, SD=.74) was significantly higher Tamale (Mean=3.5, SD=1.17), $X^{2}=$ 19.96, $p=.001$. Besides, Tamale students' views expressed were varied as accentuated by fairly high standard deviations $(1.23,1.15$ and 1.17$)$. The possible explanation could be that in Tamale, teacher supervision of students during internship was absent however individual teachers on their own volition assisted students. The differences in the means suggest that the efficacy of the curriculum materials on the organisation of student internship to some extent is dependent on support of the polytechnic management in internship.

Table 5.4 Influence of curriculum materials on student internship - students' perspectives

\begin{tabular}{|c|c|c|c|c|c|c|}
\hline \multirow[b]{2}{*}{ Statement } & \multicolumn{2}{|c|}{$\begin{array}{l}\text { Takoradi } \\
(N=132)\end{array}$} & \multicolumn{2}{|c|}{$\begin{array}{l}\text { Tamale } \\
(N=75)\end{array}$} & \multirow[b]{2}{*}{$X^{2}$} & \multirow[b]{2}{*}{ Sig } \\
\hline & Mean & $S D$ & Mean & $S D$ & & \\
\hline $\begin{array}{l}\text { Teacher supervision of students on } \\
\text { internship has improved }\end{array}$ & 3.9 & 0.89 & 2.7 & 1.23 & 64.37 & $.0005^{*}$ \\
\hline $\begin{array}{l}\text { Teacher involvement in student } \\
\text { internship has improved }\end{array}$ & 3.8 & 0.92 & 2.8 & 1.15 & 47.93 & $.0005^{*}$ \\
\hline $\begin{array}{l}\text { Hospitality industry supervision of } \\
\text { students has improved }\end{array}$ & 4.0 & 0.74 & 3.5 & 1.17 & 19.96 & $.001^{*}$ \\
\hline $\begin{array}{l}\text { Student competencies have ever since } \\
\text { the curriculum materials were used } \\
\text { have improved }\end{array}$ & 4.1 & 0.72 & 4.1 & 0.92 & 8.96 & .062 \\
\hline
\end{tabular}

Note: rating scale: 1 , strongly disagree; 2 , disagree; 3 , neutral; 4 , agree; 5 , strongly agree; $\mathrm{SD}$, Standard deviation; ${ }^{*} p<0.05$.

Extracts from focus group interviews further confirm the usefulness of the curriculum materials to the 2010 internship, both students of Takoradi and Tamale pointed out that the curriculum materials helped in writing the industrial report and gave prior information about what to expect in the various sections in the hospitality industry. According to the focus group the curriculum materials also improved their questioning skills and gave the industry-based supervisors the guidelines to follow to train interns and were used as a reference document. 
In sum, teachers, management representatives, industry personnel and students acknowledge the curriculum materials were used by students and industry during the 2010 internship which might have contributed to positive influence on the organisation of student internship. However, Takoradi teachers and students' perceptions on teacher supervision, teacher involvement, industry supervision and improvement in student competencies as a result of the influence of the curriculum materials were much higher than their counterparts in Tamale. Admittedly, industry personnel perceived the curriculum materials as a good guide to student internship but personnel from Tamale expressed Tamale Polytechnic should show more commitment to student internship.

The statements in Table 5.5 were formulated based on the challenges student faced during internship which were identified in the context and needs analysis (Akomaning et al., 2011). Data from teacher and student questionnaires, teacher, management representative and industry interviews were elicited to address the implementation challenges (Research question 3).

\subsubsection{Teacher perspective on improved practices}

Table 5.5 addresses internship challenges through curriculum materials designed by the design teams. The mean scores on all the variables were very high (Takoradi teachers: mean range 3.9 to 4.9 ; Tamale teachers: 4.0 to 4.9 ). Tamale teachers were more positive in their perceptions of the curriculum materials as addressing the challenges faced by interns during internship than Takoradi. The least of means was industry workers cooperate and support students during internship (Takoradi, mean=3.9, SD=1.53; Tamale, Mean=4.0, $\mathrm{SD}=.76$ ). The relatively high standard deviation (1.53) denotes that the views of Takoradi teachers were varied. The possible explanation could be that Takoradi teachers were quite ambivalent on industry staff cooperating and supporting students during internship. Generally, the teachers reported that students were treated with respect by industry staff, meaningful duties were assigned to students, students served in different sections of industry, industry supervision was properly carried out and teacher active involvement in internship was appreciable. 
Table 5.5 Addressing internship challenges through curriculum materials - teachers' perspectives

\begin{tabular}{|c|c|c|c|c|}
\hline \multirow[b]{2}{*}{ Statement } & \multicolumn{2}{|c|}{ Takoradi $(N=15)$} & \multicolumn{2}{|c|}{ Tamale $(N=8)$} \\
\hline & Mean & $\begin{array}{l}\text { Std. } \\
\text { Dev. }\end{array}$ & Mean & $\begin{array}{l}\text { Std. } \\
\text { Dev. }\end{array}$ \\
\hline Students on internship are treated with respect. & 4.5 & 0.52 & 4.6 & 0.52 \\
\hline $\begin{array}{l}\text { Meaningful work assigned to students during } \\
\text { internship. }\end{array}$ & 4.6 & 0.51 & 4.6 & 0.52 \\
\hline $\begin{array}{l}\text { Opportunity to serve in all departments in industry } \\
\text { during internship. }\end{array}$ & 4.9 & 0.26 & 4.8 & 0.46 \\
\hline $\begin{array}{l}\text { Industry workers cooperate and support students } \\
\text { during internship. }\end{array}$ & 3.9 & 1.53 & 4.0 & 0.76 \\
\hline $\begin{array}{l}\text { Industry to ensure proper supervision of students } \\
\text { during internship. }\end{array}$ & 4.7 & 0.59 & 4.9 & 0.35 \\
\hline $\begin{array}{l}\text { HCIM teachers' active involvement in student } \\
\text { internship. }\end{array}$ & 4.4 & 0.83 & 4.9 & 0.35 \\
\hline
\end{tabular}

Note: rating scale: 1 , strongly disagree; 2 , disagree; 3 , neutral; 4 , agree; 5 , strongly agree.

In reaction to the interview question How have the implementation challenges of student internship been resolved in the curriculum materials? Fourteen Takoradi teachers explained that the curriculum materials facilitated job rotation, while prior to the introduction of the curriculum materials, students who went on internship complained that they were kept in one section of the hospitality industry and assigned to menial work. Currently, students serve in the various sections so they are able to equip themselves with the knowledge and skills in the entire hospitality industry, particularly, in the areas of food production, food and beverage service, housekeeping and front office operation. Seven teachers from Takoradi also indicate supervision of students during internship had improved specially industry supervision. While three of the teachers express that students had the cooperation from industry staff, while prior to the introduction of the curriculum materials students reported the unfriendly nature of staff toward them. A remark made by a Takoradi teacher is captured as: "With the introduction of the curriculum material I don't think students face any challenges as compare with what they had some time ago. Even if there are some challenges they have all been minimised. Now there is job rotation and cooperation between students and industrial staff according to reports by students. Meaningful and challenging duties are assigned students".

In responding to the same interview question, five Tamale teachers report students served in different sections of the hospitality industry under different sectional heads during internship which used not to be the case. Regarding the cooperation 
of industry workers with students during internship, five teachers confirmed that through interaction with students after internship, students indicated that workers were friendly and cooperative. While three teachers assert that supervision of industry personnel was effective prior to the inception of the curriculum materials students complained that supervision was poorly carried out.

Regarding the resolution of the implementation challenges as a result of the use of the curriculum materials, teachers identified improvement in the polytechnicindustry relationship. Two of the teachers, each from Takoradi and Tamale advocate the use of the curriculum materials because they have the tendency of improving relationship between the polytechnics and industry where students carry out their internship. A Takoradi teacher testifies as, "Yes, the curriculum materials are very relevant in the sense that they improve the relationship between industry and the polytechnic so that they will inculcate in students the requisite skills to meet the needs of industry". Her Tamale counterpart indicates, "The curriculum materials have the tendency to help the students and also the tendency to improve relation between the polytechnic institution and industry".

\subsubsection{Industry perspective on improved practices}

In addressing the interview question How have the implementation challenges of student internship been resolved in the curriculum materials? All 11 hospitality industry personnel state they allowed students to serve in the various sections of the industry during internship. Five of them indicated students were effectively supervised and two expressed teachers' supervision as well during internship. Four of the personnel explained they were very cooperative and friendly toward students during internship which was not the case previously. One of the personnel expresses improved supervision on the part of industry and polytechnic (Takoradi) as well as improvement in polytechnic-industry collaboration. He stated, "Polytechnic has become more proactive in internship e.g. sometimes assisted in students getting places, supervision of students by industry and polytechnic has improved. Polytechnic-industry collaboration has improved over the period. We liaise with polytechnic regarding students' performance. Previously teachers did not demand for feedback on students' performance or conduct but now they do".

Another manager of industry indicates students were assigned to different sections of the industry and assigned meaningful and challenging duties. He explained, "Normally when a student comes on attachment I try to rotate him/her in the 
various departments of the facility; thus if I put them in the kitchen for one week I put them in the front office for another week and so on. I make sure that before the student leaves the hotel she/he has an in-depth knowledge and skills about the various sections of the hotel industry by assigning them to meaningful and challenging tasks".

\subsubsection{Student perspective on improved practices}

Table 5.6 reveals students' views on the resolution of internship challenges through the curriculum materials. Generally, mean scores on all the variables were high (Takoradi: 4.2-4.8; Tamale: 4.0-4.8). There were no significant differences between the opinions expressed on how internship challenges had been addressed in the curriculum materials. However, on the variable HCIM teachers' active involvement in student internship, views of Tamale students were varied as the relatively high standard deviation suggests $(\mathrm{SD}=1.14)$. A possible explanation could be that the students of Tamale perceived their teachers' involvement in student internship needs to be revamped.

Table 5.6 Addressing internship challenges through curriculum materials - students' perspectives

\begin{tabular}{|c|c|c|c|c|c|c|}
\hline \multirow[b]{2}{*}{ Statement } & \multicolumn{2}{|c|}{$\begin{array}{l}\text { Takoradi } \\
(N=132)\end{array}$} & \multicolumn{2}{|c|}{$\begin{array}{l}\text { Tamale } \\
(N=75)\end{array}$} & \multirow[b]{2}{*}{$X^{2}$} & \multirow[b]{2}{*}{ Sig. } \\
\hline & Mean & $S D$ & Mean & $S D$ & & \\
\hline $\begin{array}{l}\text { Students on internship are treated with } \\
\text { respect. }\end{array}$ & 4.7 & 0.60 & 4.7 & 0.58 & 4.68 & .321 \\
\hline $\begin{array}{l}\text { Meaningful work assigned to students } \\
\text { during internship. }\end{array}$ & 4.6 & 0.59 & 4.6 & 0.52 & 1.81 & .612 \\
\hline $\begin{array}{l}\text { Opportunity to serve in all departments } \\
\text { in hospitality industry }\end{array}$ & 4.8 & 0.46 & 4.8 & 0.50 & .362 & .834 \\
\hline $\begin{array}{l}\text { Industry workers cooperate and } \\
\text { support students during internship. }\end{array}$ & 4.3 & 0.80 & 4.4 & 0.88 & 4.51 & .341 \\
\hline $\begin{array}{l}\text { Industry to ensure proper supervision } \\
\text { of students }\end{array}$ & 4.5 & 0.59 & 4.5 & 0.66 & 5.15 & .161 \\
\hline $\begin{array}{l}\text { HCIM teachers' active involvement in } \\
\text { student internship }\end{array}$ & 4.2 & 0.80 & 4.0 & 1.14 & 7.00 & .136 \\
\hline
\end{tabular}

Note: rating scale: 1 , strongly disagree; 2 , disagree; 3 , neutral; 4 , agree; 5 , strongly agree.

Data from focus group interviews of Takoradi and Tamale confirm the renewed student internship practices. Students unanimously explained that during the internship programme challenging and meaningful work/duties were assigned by industry-based supervisors to interns. The needed guidelines were given to interns to follow when executing assigned duties. Workers were friendly, cordial 
and ready to help or teach students. Moreover, students were permitted to serve in all the four main sections of the hospitality industry. It is quite refreshing that students were allowed by industry personnel to practise in the main sections of their outfits. This report was contrary to the previous study where students complained about being restricted to a section and given menial and manual jobs to perform (Akomaning et al., 2011).

From student questionnaire data, majority $(68 \%)$ of the students practised in at least three sections in the hospitality industry. Takoradi Polytechnic recorded a 100 percent student participation whilst Tamale 72 percent. These figures suggest there had been some improvements over the previous (Takoradi $80 \%$; Tamale $43 \%$ ) which might imply students have understood and appreciate the importance of student internship. In the same vein the length of time students spent during internship periods have improved. Takoradi Polytechnic recorded about $93 \%$ (previous $80 \%$ ) of the students spending between eight and 12 weeks in internship whereas Tamale Polytechnic $63 \%$ (previous $60 \%$ ) of the students. It could be inferred that the introduction of the curriculum materials might have influenced students to stay longer in internship.

\subsubsection{Management representative perspective on improved practices}

In consonant with their teachers, management representatives corroborate that internship supervision has improved from both polytechnic and industry, and students were not restricted to one section of industry throughout the period of internship. Comments made by two of the management representatives are worth considering: "When we go to the field we see industry supervisors commending our students because Takoradi Polytechnic teachers usually go on supervision but teachers from other polytechnics do not. So, in the sense of uniformity I suggest that curriculum material will be adopted by all polytechnics". "My perception is that it has improved student industrial attachment. Unlike previously when students served in one department, now students serve in different department of the hospitality industry. Most students were trained in all sections of the industry and therefore better prepared for the world of work". Their counterparts in Tamale did not supervise but realised the zeal demonstrated by students on internship programme. One of them said, "The response has been quite encouraging from time to time you hear students call to tell me of where they are doing their attachment and requesting me to come and supervise them. Such calls indicate students' interest and commitment to industrial attachment of late. Students also start early looking for places for industrial attachment". 
In conclusion, teachers, management representatives, industry and students acknowledge the implementation challenges identified in the context and needs analysis have been resolved through the curriculum materials. These were: industry workers treat students with respect, job rotation, meaningful and challenging work assigned students, industry and teacher (Takoradi only) supervision had improved, students spent lengthier time in internship, and improvement in the number of student participants in internship. Moreover, teachers and industry identify the use of the curriculum materials as a pivotal factor of improving polytechnic-industry collaboration. However, industry cooperation and support of students need to be strengthened as well as teacher and management representative supervision particularly in Tamale.

\subsubsection{Teacher opinions}

The perceptions of teachers and polytechnic management representatives towards CCD for realising curriculum improvement are presented in Table 5.7. It is very refreshing that teachers from both Tamale and Takoradi Polytechnics were very appreciative of the design teams as a potential learning environment where teachers could improve their content knowledge, gain new ideas, realising curriculum improvement and solving problems in subject areas. In view of these learning potentials, teachers would not mind spending time in design team sessions and would consider it as an option in educational reform. Generally, means of teachers' views to design teams were very high (Tamale: 4.4-4.8; Takoradi: 4.2-4.8). However, on the variable I do not mind to spend time in CCD sessions because of its benefits, the views of Takoradi teachers were varied as the standard deviation (0.94) was relatively very high. A plausible explanation could be that Takoradi teachers expressed the time for CCD meetings to be further demand on them in view of their busy schedule. 
Table 5.7 Opinions of teachers towards CCD in design teams

\begin{tabular}{|c|c|c|c|c|}
\hline \multirow[b]{2}{*}{ Benefit } & \multicolumn{2}{|c|}{$\begin{array}{c}\text { Tamale } \\
(N=8)\end{array}$} & \multicolumn{2}{|c|}{$\begin{array}{c}\text { Takoradi } \\
(N=15)\end{array}$} \\
\hline & Mean & $\begin{array}{l}\text { Std. } \\
\text { Dev. }\end{array}$ & Mean & $\begin{array}{l}\text { Std. } \\
\text { Dev. }\end{array}$ \\
\hline $\begin{array}{l}\text { I will consider CCD in team as an option in curriculum } \\
\text { design. }\end{array}$ & 4.4 & 0.52 & 4.5 & 0.64 \\
\hline $\begin{array}{l}\text { I do not mind to spend time in CCD sessions because of } \\
\text { its benefits. }\end{array}$ & 4.5 & 0.54 & 4.2 & 0.94 \\
\hline $\begin{array}{l}\text { Design team can help me to collaborate with other } \\
\text { teachers in realising curriculum improvement. }\end{array}$ & 4.5 & 0.54 & 4.5 & 0.64 \\
\hline Design team can help improve my content knowledge. & 4.5 & 0.54 & 4.5 & 0.52 \\
\hline $\begin{array}{l}\text { Design teams can help me to solve problem in my } \\
\text { subject area. }\end{array}$ & 4.4 & 0.52 & 4.4 & 0.63 \\
\hline $\begin{array}{l}\text { Design team can help me learn new ideas about student } \\
\text { internship. }\end{array}$ & 4.8 & 0.46 & 4.8 & 0.41 \\
\hline $\begin{array}{l}\text { Design teams can help me to design improved curricular } \\
\text { material. }\end{array}$ & 4.4 & 0.52 & 4.5 & 0.52 \\
\hline
\end{tabular}

Note: rating scale: 1 , strongly disagree; 2 , disagree; 3 , neutral; 4 , agree; 5 , strongly agree.

In responding to the interview question What are the motivating factors relating to the sustainability of CCD for improved curriculum materials? All fifteen Takoradi teachers state the CCD in teams as a means of enhancing shared expertise. Thus as teachers collaborate in teams they were able to express their thoughts on whatever subject that was brought for discussion. In that collegial environment of sharing their experiences, teachers tend to unlearn and learn from colleagues and for that matter were better enabled to fine-tune their stock of knowledge and skills which promote student learning both on-campus and in industry. A Takoradi teacher who benefited from the content knowledge and skills in hospitality management programme had this to say, "I think that the fact that teachers are able to learn from a colleague for me is helpful. I didn't do catering but I have learnt from colleague teachers, techniques and skills underlying large scale cooking and more ideas through design teams. So I think it is very helpful and motivating and for this reason CCD in teams must continue".

Another Takoradi teacher articulates her position as CCD as a means to improve her stock of knowledge and subsequently improve student learning. "Because $C C D$ serves as a platform which guides teachers involved. Through brainstorming teachers are able to unlearn the wrong concepts and learn the right ones. It helps teachers to convene to students what they are supposed to. So, I think that CCD in team is very 
good and necessary because it shapes the content knowledge of teachers and therefore able to impart the right stuff and students are able to grasp the right things. No body is a repertoire of all information so when we come together to design a thing like this, we share ideas and eventually we come out with something good".

In answering to the same interview question, all eight Tamale teachers explain CCD in teams gave rise to improvement in shared expertise which culminates in improved student learning on campus and in industry during internship. Products designed are easily implemented in the spirit of teamwork. An opinion expressed by a Tamale teacher on CCD as platform for sharing of ideas, improving teaching and learning. She remarked, "Because during CCD in teams we put our ideas together and eventually select the best way out thereby improving teaching and learning. The good ideas we come out with are then implemented. So CCD in team is a good idea and should be encouraged".

From the interview question What is your overall perception towards continuation of $C C D$ in teams for improvement in curriculum for student internship in the polytechnic? All Takoradi teachers express positive perceptions towards the continuation of CCD in teams for improvement in curriculum for student internship in the polytechnic in the sense that it creates the platform for teachers to deliberate on issues affecting student learning. Hence the organisation of internship in the polytechnic had greatly improved. Two of the teachers advocated its formalisation; thus to be a part of academic calendar of the polytechnic. "CCD in team is good and should be continued in the sense that it helps us to update whatever we put down, to improve whatever situation or problem that comes up. It also helps us to plan ahead," as explained by one of the teachers.

Tamale teachers (all) in responding to the same interview question applauded CCD in design teams as a source of designing curriculum to improve student internship. Awareness is created about the significance of internship through the activities of the teacher teams. All the teachers recommended design teams' activities should be encouraged and sustained in the polytechnic. A teacher remarked her content delivery had improved considerably as a result of the deliberations that went on among teachers.

Of the 23 teachers, eight recognised (2 from Takoradi and 6 from Tamale) that $\mathrm{CCD}$ in design teams does not only improve curriculum content but also facilitates implementation as well. In support of this position, one of the Takoradi 
teachers said, "CCD in design team is a platform where teachers actually get involved in the design of curriculum will actively commit to improvement in its quality and ensure implementation is facilitated". Her colleague in Tamale states, "As teacher initiative with input from other stakeholders, whatever plan toward curriculum for student industrial attachment will be of quality and eventually will be carried out very well".

\subsubsection{Management representative opinions}

Management representatives of Takoradi in reacting to interview question What are the motivating factors relating to the sustainability of CCD for improved curriculum materials? They had the opinion that CCD in teams was a platform for teachers to come together to design curriculum materials which enhances sharing of diverse ideas and reaching consensus by achieving stated objectives. Moreover, teachers who design claim ownership and for that matter will see to the implementation of whatever is designed. Eventually, teachers are able to improve teaching and learning.

In answering the same interview question, management representatives of Tamale indicated that teachers were key stakeholders to student internship so as they collaborate with each other they were able to identify problems associated with student learning and better equipped in teams to find solutions. So, there is the likelihood of very high level of commitment in the design process and whatever they are able to come out with they would remain committed to implement. In this regard, CCD should be sustained. A management representative's comments on reasons why CCD in team should be considered as an option in an educational reform in the polytechnic are presented as: "You will realise that many educational reforms are top-down approach; oftentimes starts with central government, goes to the sector Ministry of Education then it goes down straight to the educational institutions and is not easy to implement when it is top-down approach because the bottom hasn't understood it very well. The bottom needs to adjust and it is all-of-a-sudden approach and the way it is implemented doesn't take into account that the bottom needs to be adjusted as a result implementation becomes very poor. But the very nature of CCD in team, the fact that it adopts a bottom-up approach I will go in for it as a better option".

The opinions expressed by management representatives of Takoradi on the sustenance of CCD in teams for improved curriculum for student internship were positive. They perceived the design teams as a platform for sharing ideas and improving on curriculum designed for internship. Consequently, internship is 
well guided, supervision improved and interns are better equipped for the world of work. A management representative's (Takoradi) remarks which corroborate the others: "I have a very positive perception concerning the sustenance of $C C D$ in teams. As teachers come together they learn from each other, the curriculum materials serve as a guide and supervision has improved tremendously. I think if other departments in the polytechnic can come out with similar curriculum materials, industrial attachment supervision will be revolutionised".

Management representatives of Tamale also lauded the idea of sustaining CCD in teams but however indicated top management is needed to support the activities of the design teams so as to ensure fullest implementation of their programme in the polytechnic. "The concept CCD in team is very laudable one but the pace of progression need to be speeded up," concluded one of the management representatives (Tamale).

To sum up, both teachers and management representatives were positive toward $\mathrm{CCD}$ as a means of ensuring improved curriculum in the polytechnics. As a solution centre, CCD offers the opportunity for teachers to discuss issues pertaining to content knowledge as well as skills and techniques in hospitality management which result in improved student learning. Consequently, whatever product designed in CCD is easily implementable with the assistance of topmanagement support.

\subsection{CONCLUSION AND DISCUSSION}

The study has provided a better understanding of the extent to which CCD in design teams as a bottom-up strategy has given rise to sustained improvement in student internship practices in the two Ghanaian Polytechnics. The results of the study indicated that CCD approach to curriculum design among teachers could be sustained in both Takoradi and Tamale. Teachers from both Takoradi and Tamale were very positive on the rationale for engaging in CCD because it could lead to improved curriculum materials for student internship. Teachers and management representatives of both institutions unanimously concurred that designing curriculum should be part of the formers' role considering the expertise of the teachers and the polytechnic as a tertiary institution. Teachers and management representatives perceive $\mathrm{CCD}$ as a platform for teachers to share 
their expertise which lead to a shared vision on curriculum goals and organisation and subsequently ownership of whatever curriculum materials designed. These are achieved if teachers value teamwork and promote teacher collaboration (cf. Kliknaite, 2009; Pertuzẻ et al., 2010; Sackney et al., 2005) with the support of management (Reichstetter, 2006).

All the respondents (teachers, management representatives, students and industry personnel) acknowledge the use of the curriculum materials designed by the design teams as having positive impact on student internship. Takoradi teachers and students perceived the curriculum materials had a much better influence on teacher supervision, industry supervision and student competencies than their counterparts in Tamale. Teachers in both institutions acknowledge students' drastic improvement in food production and housekeeping operation as a result of the use of the curriculum materials during internship. All the respondents also realise that the hitherto challenges faced by students during internship prior to the use of the curriculum materials were resolved considerably. These were industry workers treat students with respect, job rotation, meaningful and challenging work assigned students (Bascia, 2005; Dixon, 2005; Durrant \& Holden, 2006), industry and teacher (Takoradi) supervision had improved (Lam \& Ching, 2007), students spent lengthier time in internship, and improvement in the number of student participants in internship. However, industry cooperation and support of students needed to be strengthened as well as teacher supervision, particularly in Tamale. Finally, the opinions of teachers and management representatives on CCD as a means to improve curriculum in the polytechnics were favourable however, teachers and industry personnel argue that management support is needed in order to realise the full potential of CCD in the polytechnics.

This study buttresses the studies by Hasbullah and Sulaiman (2002) and Ko (2008) on interns' smooth transition to the world of work as a result of guided internship. The perceptual mean scores for Takoradi students on the influence of the curriculum materials on the organisation of internship were significantly higher than their counterparts in Tamale which implies that the context within which the curriculum materials is implemented determines the extent of the influence. In other words the various stakeholders should play their distinctive roles so as to ensure the success of student internship (Akomaning et al., 2011).This study confirms Billett (2006) and Blokhuis and Nijhof (2008) assertions that the workplace 
should be conceptualised and acknowledged as authentic learning milieu for interns which is made possible through a guided internship curriculum.

Institutions of higher education that enrol students for internship should endeavour to provide the needed resources for teachers to supervise and advance and improve contacts with industry. They should also have plans for awarding marks to internship and mandatory writing of student industrial reports will go a long way to enhance the organisation of internship which could drastically improve student participation in internship to a near 100 percent. With tourism and hospitality industry becoming a major source of job creation and major foreign exchange for countries across the globe, it is imperative for institutions offering hospitality management programmes to put in measures that will foster the preparation of students for the hospitality industry.

Favourable opinions expressed by teachers and management representatives toward CCD as a means to improve curriculum are in consonant with the studies by Blankstein (2004) and Hirsh and Killion (2007) that teachers would be positive toward teams if their interests and needs are catered for e.g., solving subject matter. CCD is an educational reform which has been embraced by all participants however, there is a hurdle which need to be cleared in order to be assured that it becomes a permanent feature of the polytechnics is formalisation of the activities of CCD in teams which would take a considerable amount of time due to the bureaucratic nature of making bottom-up approach fully accepted and internalised as a policy. Anyway the response from management representatives is quite reassuring but frantic effort need to be carried out by the departments' heads in order to facilitate its formalisation (CCD) as a means to improve curriculum in the polytechnics. 


\title{
CHAPTER 6 Reflections
}

\begin{abstract}
This design-based research attempted to provide quality curriculum materials and renewed and sustainable student internship practices through collaborative curriculum design in design teams. This chapter reflects on the outcomes of the research, starting with summarising the research phases and results, followed by a reflection on the research approach. Next, the outcomes of the research are discussed. Finally, the chapter ends with recommendations for stakeholders and directions for future research.
\end{abstract}

\subsection{RECAPPING RESEARCH PHASES AND RESULTS}

The polytechnic education in Ghana gained tertiary status in 1993 with the aim to prepare its students with practical skills to occupy middle level manpower on the occupational ladder. To fulfil this mandate, the polytechnics in Ghana have adopted an internship programme which complements what is taught in the educational institutions. The Department of Hotel Catering and Institutional Management (HCIM) is one of the academic departments of the polytechnic whose mandate is to train its students to assume positions of supervisors or managers in the hospitality industry. It is a three-year programme meant to equip its students with the required competencies which prepare them for industry.

The purpose of this research was to improve student internship practices by designing quality curriculum materials through collaborative curriculum design in teacher design teams, with inputs from students and industry personnel. This research endeavours to gain a better understanding of issues related to design teams collaboratively designing curriculum materials in the context of curriculum innovation. The aim of the research was to investigate how collaborative curriculum design in design teams was adopted to design curriculum materials to improve student internship practices in the Department of HCIM. Based on this 
focal point, the central question was framed as follows. In which ways does collaborative curriculum design in design teams contribute to quality curriculum materials for sustainable student internship practices in the polytechnics?

In order to find answers to the main question, the following sub-questions informed the research:

1. What are the perceptions and suggestions among the various key stakeholders of HCIM education regarding student internship and its organisation?

2. Does collaborative curriculum design in design teams contribute to an improved curriculum for student internship?

3. Do the curriculum materials produced by the design teams contribute to renewed student internship according to the stakeholders involved?

4. To what extent does collaborative curriculum design lead to sustainable student internship practices according to the various stakeholders?

The research model presented in chapter 1 (see Figure 6.1) illustrates how collaborative curriculum design was connected to the various components that determined the design of curriculum materials for internship practices. The needs and context study provided the objectives and conditions for the adoption of collaborative curriculum design in design teams as a bottom-up approach to solve the implementation challenges of student internship through the design of curriculum materials to guide student internship. Research question 1 sought to address the state in which student internships were executed within the Departments of HCIM by drawing out the perceptions and suggestions of the students, alumni, teachers, management representatives and industry personnel of the hospitality management programme. The second and third research questions respectively were formulated to guide the two design and implementation studies, in which teachers collaboratively designed and implemented curriculum materials for student internship with input from students and industry. Finally, the model presents the impact study which was guided by the fourth research question and sought to ascertain how the activities of collaborative curriculum design in teams resulted in quality curriculum materials and renewed and sustainable internship practices. Additionally, the sustainability of collaborative curriculum design itself was studied during the impact study. The supposition underlying the research project was that as teachers collaboratively design curriculum materials having received inputs from key stakeholders (students and industry personnel), they own the product 
designed and would see to its implementation resulting in quality curriculum materials for sustainable internship practices.

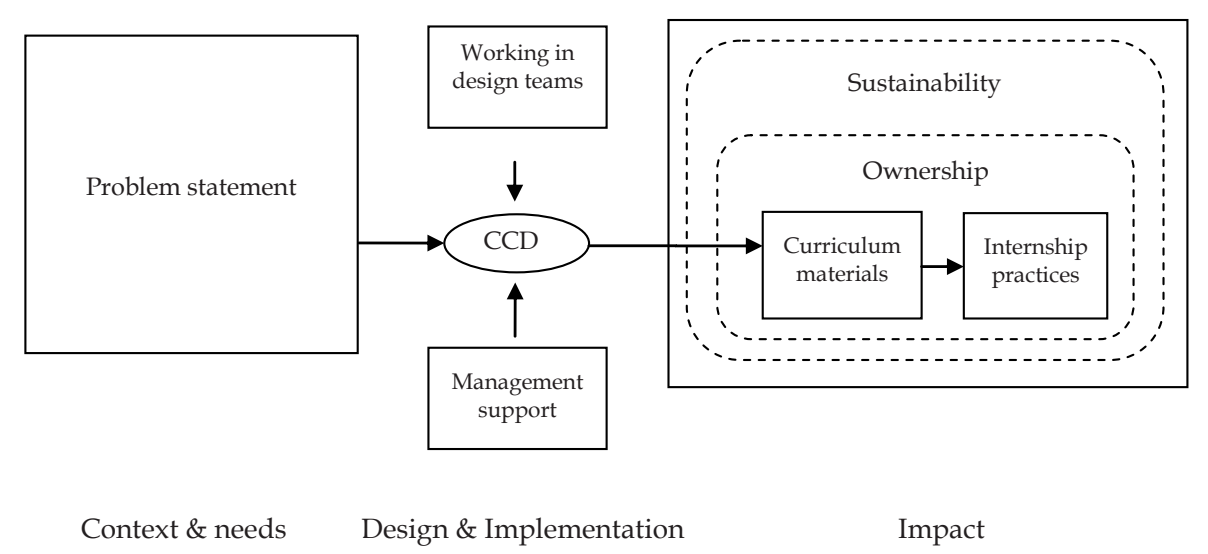

Figure 6.1 The model connecting the stages of the research to CCD

\section{Context and needs analysis}

A context and needs analysis was carried out in the Departments of HCIM of four polytechnics in Ghana (full disclosure in chapter 2). The objective for this substudy was to unearth the nature of the needs and challenges facing the organisation of student internship and to identify the conditions. Further, to elicit information from respondents concerning suggestions that would help improve student internship. Research question 1 addressed stakeholders' perceptions on the organisation of student internship. The major findings showed that students were assigned to one department for the entire training period in industry, jobs/duties assigned were manual and menial, supervision was lacking, an uncooperative nature of workers towards interns existed, students were not able to fulfil the mandatory period of three months internship, $20 \%$ of students did not get an internship placement and the relationship between the polytechnics and industry was episodic. The need for curriculum materials to guide student internship was expressed, since it was found that student internship had no written curriculum specifying the distinctive roles of teachers, students and industry personnel during internship.

Regardless of the challenges students faced during internship, alumni, teachers and industry's assessment of interns' job performance was quite satisfactory. Teachers, students, alumni, management representatives and industry personnel were 
however prepared to make the organisation of student internship better. In this regard, teachers, management representatives as well as industry personnel pledged to get actively involved in student internship by way of supervision and improving on the industry-polytechnic relationship. Industry personnel were positive toward redoubling support in the training of students during internship. Stakeholders also concurred with the extension of time spent in industry by interns. With collaboration not formalised between polytechnic and industry, it was likely that they did not understand their distinctive roles when it came to student internship.

\section{First design and implementation study}

Following the context and needs analysis, the first design and implementation study was carried out in one of the four study sites, Department of HCIM, Tamale Polytechnic. This study was guided by research question 2. Teachers constitute themselves into two design teams and collaborated to design curriculum materials for student internship. The central features of the curriculum documents were objectives of student internship, content description of the four core areas of the hospitality industry, practical activities the students had to carry out during student internship, intern serving in all sections/departments of hospitality industry, and the explicit distribution of roles between students, teachers and industry. The materials were prepared with inputs from students and industry representatives. The curriculum materials were used during the 2009 student internship.

Self-report data showed that teachers appreciated to be involved in collaborative curriculum design that improved their collaborative skills while working in design teams. The implementation of the curriculum materials showed that the link with industry still needed to be strengthened, and teachers' active involvement in supervision of students during their internship was absent. However, the students, teachers and industry reported improvements in internship practices: the number of participating students had increased, as had the duration of internship, students served in different sections of industry (job rotation), the expected objectives for internship were met, industry personnel supervision was improved and industry staff cooperated with interns. Interns reported to have improved on their competencies significantly compared to those students who did not go through internship (chapter 3 captures the full report). 
Second design and implementation study

Similar to the first design and implementation study, this study was carried out in the Department of HCIM at Takoradi Polytechnic with the ultimate aim of improving the quality of curriculum materials designed as well as student internship practices. Based on the aim, the third research question was formulated to guide the study. In the second design and implementation study, curriculum materials for student internship were collaboratively designed by design teams of teachers with inputs from students and industry representatives and implemented in the 2010 student internship in 50 hotels.

The findings of the study showed that the design teams shared their (practical) experiences in internship, sent draft materials to stakeholders for scrutiny, and included suggestions from stakeholders. Teachers reported that they appreciated the work in teams because they perceived the work as important and of high quality.

Stakeholders concurred with the practical usefulness of the curriculum materials in the training of students and the subsequent outcomes of student self-assessed competencies and industry-based assessment were commendable. Teachers, students and industry personnel acknowledged the curriculum materials as a guide to students' training. Internship practices improved in the areas of supervision, workers started to cooperate with interns, job rotation was introduced, and work assigned to interns was seriously managed. The polytechnic-industry link was improved though not directly linked to the curriculum materials, which resulted in a rise in the duration of internship, and an increase in the placement and participation of interns. The full account is presented in chapter 4 .

Impact study

The final study aimed to explore the influence of the curriculum materials on the organisation of student internship one to two years after the intervention, as well as the opinions of teachers and management on collaborative curriculum design as a means to improve the curriculum. The fourth research question was formulated to guide this study. Through the design activities and the resulting curriculum materials, the relationship between the polytechnics and industry had improved, supervision of students during internship by teachers, particularly that of Takoradi, had improved considerably, which motivated students to participate fully in internship. Teachers and management representatives indicated students had shown more commitment and seriousness toward internship and marked improvement in supervision of student internship. 
Teachers reported that they had learned from each other during collaborative curriculum design in teams. The results indicated that collaborative curriculum design in teams had been sustained as reported by teachers and management representatives. Teachers were highly optimistic that the introduction of collaborative curriculum design had paved a way for them to work in teams in designing curriculum materials for student internship. (Full disclosure presented in chapter 5).

\subsection{REFLECTING ON THE RESEARCH APPROACH}

A design research approach was adopted to guide this research project, because of its aim to contribute to the practical relevance of research in addition to its scientific outcomes (Van den Akker, Gravemeijer, McKenney, \& Nieveen, 2006). By carefully studying interventions in their target contexts, researchers and practitioners construct workable and effective interventions, with improved articulation of principles that underpin their impact (Collins, Joseph, \& Bielaczyc, 2004; Van den Akker, 1999).

Typical for design research, as was also the case in this research project, is that the researcher plays various roles during the different phases of the research. In the present research project the researcher was the facilitator organising workshops, was observer seeing to the proceedings of collaborative curriculum design in teacher teams, and was the researcher collecting data at the various stages of the research. Care was however taken not to compromise on the validity and reliability of the research by ensuring triangulation through the use of multiple data sources, multiple data methods and the involvement of multiple coders in the analysis of the qualitative data (cf. Cohen, Manion, \& Morrison, 2007).

In this research both qualitative and quantitative methods have been utilised, to allow the researcher to develop an overview, as well as an in-depth understanding of the problem (chapter 2) and the quality of the solution (chapters 3-5). However, apart from researcher's own observations, the systematic data collection was mainly based on self-reported data, and therefore measured perceptions and experiences in particular, which might have biased the findings of this research. To be able to give a balanced answer of the research questions multiple data sources were used to allow for different perspectives in answering the research questions. 
Many design research studies only report the immediate evaluation outcomes of the interventions. In this research an effort was made to explore the effects of the intervention after one to two years (chapter 5, impact study). The results of the impact study confirmed the importance of the curriculum materials for improved internship practices and the interest of teachers and management in collaborative curriculum design as a means to improve curriculum. The impact study could be considered an interesting alternative to summative evaluation in design research, because it shows the long term effect of the intervention.

Another pressing issue in design research is the lack of statistical generalizability of the findings. The fact that the research took place in a natural setting in a limited number of purposefully sampled polytechnics limited the statistical generalizability of the findings of this study. However, generalizability could be realised through the formulation of design principles. In this research, the principles governing collaborative curriculum design (identification of problem, conditions for working in teams and institutional support) could be generalized. A more fruitful perspective on the issue of generalizability for design research is the concept of ecological generalizability (Flagg, 1990), which implies that the context, problem, intervention and conditions are clearly described, so that others can judge whether the study findings are generalizable to their 'ecology'.

\subsection{OUTCOMES AND REFLECTIONS}

The major research question guided this research project was In which ways does collaborative curriculum design in design teams contribute to quality curriculum materials for sustainable student internship practices in the polytechnics? In this section, this research question will be answered and reflected upon. The research model (see Figure 6.1) will be used to structure this section.

Importance of the context and needs analysis

The importance of context within which needs are identified in a research project cannot be underestimated. The context of this research is the Department of HCIM in polytechnics in Ghana regarding the organisation of student internship. The implementation challenges emerged out of the context and needs analysis study which informed the industrial liaison officers, teachers, students and industry personnel (key stakeholders) of the hospitality management programme. Following 
this awareness creation, the stakeholders, particularly the teachers expressed the need for well thought curriculum documents to be designed to help streamline the student internship. The need to design curriculum documents therefore prompted the formation of collaborative curriculum design in design teams as a bottom-up approach feasible in addressing the implementation challenges.

\section{Collaborative curriculum design: necessary conditions}

Capacity has been identified as one of the missing links in the organisation of student internship in Ghana's polytechnics. In the context of student internship, its description was unstructured and faced with challenges. Hence the expected mandated functions or roles of teachers, students and industry personnel were not efficiently and effectively executed. In view of this, the research sought to address the challenges by adopting collaborative curriculum design as a bottomup approach of empowering teachers in the Departments of HCIM. Teachers in design teams (with inputs from students and industry representatives) (cf. Hughes, 2009) designed curriculum materials to help streamline the activities of student internship. The functionality of the collaborative curriculum design in design teams depends on whether the conditions to work in teams are in place and how management of the educational institutions lend support to their activities. Regardless of the individual differences, teachers were able to share their professional experiences in the teams and discuss the rationale and contents of the curriculum materials designed. These were the watchwords of the teachers that facilitated them to concur in their teams: professional commitment, interdependence, healthy interpersonal relationship, mutual respect and participative decision making. These findings confirm the notion also found by Little (1990) and Riordan (2001) that shared responsibility, high levels of trust, respect, and mutuality are crucial for successful products of design teams.

It is quite refreshing that teachers and management representatives were appreciative of the concept and activities of design teams in the polytechnics. With the provision of space, time and relevant documents from the management of the polytechnics, a relatively enabling environment was created for the teachers to be able to work in teams as curriculum makers (cf. Clandinin \& Connelly, 1992). Management support in this study was found crucial to not only make collaborative curriculum design successful, but also for the implementation of student internship, the role of the teacher in particular. 


\section{Quality curriculum materials for improved internship practices}

In the preparation of the curriculum materials, the design teams considered the student and the environment where the student will go for internship (industry premises, working conditions of industry, supervisor, customers etc) as critical factors in determining student learning (cf. Darling-Hammond \& Snyder, 1992). The design teams had the notion that the student during internship should be guided (by the workplace supervisor) but not be controlled.

The curriculum materials as basic resource to guide student internship were developed following Van den Akker's (2003) components to describe a curriculum. The materials had a clear-cut rationale indicating hospitality industry staff should endeavour to guide students during internship by ensuring that students serve in all the sections in the industry and assigning them to meaningful and challenging tasks with the intent of better preparing students to transit smoothly from school to work. The objectives of student internship were made explicit; content of the curriculum materials were departmentalised into four having regard of the grade levels of students. Important in the materials were a clear definition of the roles of stakeholders (students, teachers and industry personnel). Activities for students were formulated as well as guidelines for student assessment in the curriculum materials. The components were systematically arranged on year group levels and duplication was eliminated. The explicit focus on different aspects of hospitality management helped to emphasise the need for job rotation (location). The components grouping (obvious) and time (although sometimes problematic in practice) were obvious in the organisation of student internship.

The contributions made by other stakeholders (students and industry representatives) during the design of the curriculum materials and the systematic arrangement of the components of the curriculum documents by design teams led to the appreciation and easy application of the documents during internship by these stakeholders. In this regard, the outcomes of this research were consonant with the study by Kessels and PIomp (1999) on ensuring curriculum quality through a "systematic relational approach", caring for internal and external consistency. To realise internal consistency Van den Akker's (2003) components for describing the curriculum were used. In this study an explicit rationale in relation to a clear distinction between the expected roles of polytechnic teachers, industry representatives and students was important, as well as coherence between content, objectives, activities and assessment, was crucial for the internal consistency of the materials and improved internship practices. 
With curriculum design, it is pivotal to bring on board the various stakeholders so that when it comes to its implementation the document will not be seen as foreign material by the users. External consistency was realised by soliciting the explicit inputs of various stakeholders in the process of curriculum design. In this research project not only teachers' active involvement was a necessary condition for the realization of valid and practical curriculum materials, also the involvement of industry and students was key to the success of the curriculum materials. To avoid the belief or the perception of the curriculum materials as being imposed (Van den Akker, 2003) on students and industry, their input was critical. It was important for stakeholders to lay claim of ownership of some sort.

\section{Ownership and sustainability}

The essence of this research project was to ensure that after design and implementation phases the reform would continue in the educational institutions hence the quest for participants (students, teachers, industry personnel and management representatives) to actively be involved in the various stages of the project was paramount. By so doing, they would not perceive the reform as an imposition from outside but would take pride in what they have been able to execute. Thus ownership, a critical component of educational reform would be internalized by stakeholders. By claiming the products as theirs, facilitate implementation and plausible positive outcomes would encourage stakeholders to sustain and even improve on practice. In this regard, the impact study was meant to access the students, teachers, management representatives and industry personnel as to how collaborative curriculum design in teams had contributed to quality curriculum for sustainable student internship practices in the polytechnics.

The sustainability of the innovation where teachers are curriculum makers (Clandinin \& Connelly, 1992; Simmie, 2007) requires commitment of participation from the bottom (teachers) and the provision from the top (management). In this research project, products designed collaboratively by the design teams were implemented during student internships in the 2009 and 2010 ( $1^{\text {st }}$ and $2^{\text {nd }}$ design and implementation studies) which resulted in marked improvement in student internship practices. The long term effects of these interventions were that curriculum documents had become available resulting in renewed and sustainable student internship practices according to the stakeholders (teachers, management representatives, students and industry personnel). 
Structured organisation of student internship in the Department of HCIM could be a blueprint for other departments in the polytechnics in Ghana to follow. Formalisation of the activities of design teams in the polytechnics would be needed to further ensure the sustainability of collaborative curriculum design in teams. The challenge that may confront this reform may be the frequent change of Heads of Department and the high staff turnover, a characteristic of the Ghanaian Polytechnics. However, formalisation of the activities of design teams as advocated by teachers could be a way of mitigating the challenge.

Currently, the polytechnics in Ghana as tertiary educational institutions have not weaned themselves completely from a regulatory body like NABPTEX (coordinating activities in curriculum design and development in the polytechnics), if collaborative curriculum design in design teams is given the needed support from all fronts (management, teachers, students and industry) the functionality of its operations would be mutually beneficial to the key stakeholders in particular and the nation in general. Finally, Ghana stands to benefit immensely if personnel for the tourism and hospitality industry are better prepared to man the sector which is estimated to be the first foreign exchange earner by 2015 (Ghana Tourist Board, 2009). The issue of graduate unemployment which is of grave concern to the nation could be greatly minimised through renewed student internships, because in this way students would be equipped with competencies needed for them to be employed or set up their own business enterprises.

\subsection{RECOMMENDATIONS}

One of the aims of design research is to identify a problem in a given context and eventually develop (design) an intervention specifying the processes (cyclical in nature) through which the problem (phenomenon) would be addressed. This section provides recommendations for continued exploration of effective adoption and adaptation of collaborative curriculum design in design teams in relation to the design and implementation of quality curriculum documents for sustainable student internship practices. Based on the successful outcomes of this research and literature this section is outlined along implications for practice, policy implications and future research. 


\section{Implications for practice}

For the curriculum materials designed for student internship to be functional over time, educators should regularly continue to liaise with industry so as to be abreast with current changes in technology as well as needs of industry. The heads of educational institutions should make sure that teachers periodically review the curriculum materials in order to reflect the realities in industry. Such reviews should be done in consultation with the representatives of industry as well as students so as to create ownership among stakeholders (Kuiper, Nieveen, \& Visscher-Voerman, 2004) and to avoid the situation of the documents (curriculum materials) being perceived as imposition (Van den Akker, 2003) from the educational institutions.

In view of the gains teachers derived from collaborative curriculum design in design teams and the willingness expressed by both management representatives and teachers to maintain collaborative curriculum design, the heads of department should be more proactive in ensuring that the activities of design teams in the department are not curtailed. Collaborative curriculum design in design teams is a bottom-up approach ensuring that educational reforms are initiated in the departments. However, the extent to which their activities would be felt in the educational institutions is dependent on how prepared teachers are for working in teams and how prepared top management of educational institution would lend support. It is very crucial for the design team as a scheme to become part and parcel of the educational institutions' calendar. Thus, the activities of design teams should be formalised and not ad hoc. Teachers and management of tertiary educational institutions should endeavour to inculcate collaborative curriculum design on their timetable and periodic workshops organised for teachers to invigorate their activities in design teams. This is an expression in the right direction and for that matter management should team up with teachers to come out with written proposals on the prospects of collaborative curriculum design in design teams in ensuring that teachers will not be seen as conduit of curriculum delivery but curriculum maker (Clandinin \& Connelly, 1992; Simmie, 2007)

Teachers should continue to work in teams during practical lessons on campus and they should endeavour to document proceedings of such meetings. The continuous meetings of the teams (planned or unplanned) and the documentation of experiences or ideas expressed by individual teachers will further deepen and entrench the activities of design teams. Despite contextual challenges, teachers of tertiary 
educational institutions should make frantic effort to encourage teamwork regardless of individual philosophies and idiosyncrasies because it is a way of improving curriculum content as well as fostering relationship with industry. Regular teacher collaboration in curriculum activities would enhance teacher competence and eventual improvement in student learning (Borko, 2004) thereby achieving the aim of tertiary education of preparing its products for the world of work.

Findings from this study suggest that quality student internship imply effective relationship between educational institution and industry. The importance of the relationship between the two parties could serve as a platform where differences regarding practice and policy could be ironed out. By so doing, they would understand their distinctive roles and complement each other which could lead to improvement in students' attitudes, knowledge and skills. Maintaining and improving on the collaboration between educational institutions and industry is a sine qua non for ensuring that students are better prepared for the world of work hence educational institutions should strive to create the conditions that would augur well for effective teamwork. Educational institutions which have offices responsible for liaising with industry and other organisations should be well resourced so that they would be able to fulfil their mandate. Such offices if their mandate is enhancing student internship could develop industrial sites (Divine et al., 2007), comprehensive data base on workplaces (organisations/industries) where students can register for internship, and it would go a long way to ease the pressures students had to go through searching for internship placement.

Other tertiary educational institutions that enrol students for internship should endeavour to liaise with the key stakeholders in drawing up curriculum materials to help streamline the activities of interns and industry practitioners in order to ensure that the purpose for which the extended programme is instituted is achieved. Guided internship is of paramount importance for all educational institutions organising internship for their students because it is a surest way of ensuring that stakeholders are held accountable.

\section{Implications for policy}

The polytechnics should endeavour to award credit hours to student internship. Internship should be considered a requirement for students graduating from the institution. In this vein, students' participation in internship will greatly improve and more seriousness will be attached. Tertiary educational institutions with 
internship programmes should award credit hours and be a requirement for students' graduation. This measure could improve student participation in internship and would urge students to be more serious toward internship programmes. Supervision of students by teachers during internship is very critical to ensuring that quality is injected into the industrial training of students. Improvement in student internship practices could be partly due to supervision by both the educators as well as industry-based supervisors. It is therefore imperative for teachers to ensure that effective supervision of students during internship is carried out. Teachers should accept supervision of interns as part of their official duty and management should provide the necessary logistics to make this possible. In order to ensure proper supervision, the educational institutions should team up with industry to draw up a scheme that would help supervisors to know what to look for.

Collaborative curriculum design in design teams should be embraced by teachers and management of educational institutions because it creates the platform for teachers to interact with one another thereby sharing their profession competence and improving quality of curriculum documents through a systematic manner of analysing the problems, designing and developing, implementing the product designed and evaluating. Such a bottom-up strategy should be part and parcel of educational institutions' timetable because it is a means of empowering teachers to assert themselves as professionals. Additionally, student learning improves as a result (Havnes, 2009).

Future research

This research explored the adoption of collaborative curriculum design in design teams to improve the quality of curriculum documents as well as sustainable improvement of student internship practices in two polytechnics in Ghana. In the design process teachers collaboratively contributed effectively in a congenial atmosphere devoid of intimidation, patiently taking their turns to express their views with the ultimate aim of designing a well-thought out curriculum for internship. This was made possible through the support of management at the various phases of this research project. The curriculum documents designed were easy to use by stakeholders but comprehensive in the sense of their broad coverage. Tertiary institutions could team up with industry personnel to carry out research projects on product designs (other than curriculum materials) through the adoption and adaptation of collaborative curriculum design so as to minimise 
or close existing gaps that normally exist between industry and educational institutions. Such joint projects could cement the relationship between the two parties and culminate in sharpening the attitudes, knowledge and skills of participants because identification of the gaps and the search for solutions are ways of bringing about improvement in existing phenomenon. Educational institutions with academic programmes perceived to be dysfunctional could adopt collaborative curriculum design to improve on their quality so as to be relevant to stakeholders.

Future research can be directed to the effectiveness of the role stakeholders play in collaborative curriculum design. Their roles can be twofold, participating in the design process, like teachers in our studies, or improving conditions for a successful collaborative design process. Recent studies on participatory design claim that implementation and outcomes of the design process can be improved through the participation of end users. In this research project, teachers, students and industry are defined as end users. In view of an effective participation of end users, students and industry personnel may also be more explicitly involved in the design process, and not only through providing input, as was the case in this research. Other studies promote the participation of management in the design process. This participation may lead to an effective implementation and sustainability, as was demonstrated in this research in chapter 5. Another issue pertaining to the involvement of stakeholders is equity. What is their input to the design process and how is this input valued by the other participants?

Another important issue related to the research model is the function of the context and needs analysis. In this research the context and needs analysis provided on the one hand the objectives to be realized through the materials for internship practices to be designed. On the other hand, the constraints under which the materials will be effective. Often a context and needs analysis is carried out to identify the problem at stake. By identifying the problem, it is important to ensure the widest possible acceptance by all concerned with the curriculum materials to be developed, especially by those who are involved in the implementation of the materials. In order to reach this commitment, those responsible for the design of the materials can provide and compose a so-called liaison group or linkage group. Members of this group are involved in analysing the problem, defining the needs, designing the eventual materials, in implementing and in evaluating the materials. It is often recommended that a 
liaison group be composed with as many different stakeholders and that the design team regularly deliberates with the members of the liaison group during the development of the curriculum materials, to ensure adoption and implementation of the materials. To some extent the input of students and industry representatives in the design proves could be considered a liaison group. However more research is needed on the composition and specific tasks of such a liaison group, the kinds of experts that need to be represented in this group, and the effectiveness of the combination of the experts. A study could be carried out studying the collaborative and design competencies of teachers in the polytechnics, since these competencies can be considered necessary for the success of collaborative curriculum design in teams. 


\section{REFERENCES}

Acquah, T. (2009, June 23). Lack of standards hit hospitality industry. Business \& Finance, p. 1.

Adjei, E., \& Gyamfi, P. (2005, October 9). Human resource management in the Ghanaian hospitality industry. Ghanaian Times, p. 6.

Agodzo, S. K. (2007). A discussion of the programmes and activities of polytechnics in Ghana. Journal of Polytechnics in Ghana, 2(2), 45-53.

Akomaning, E., Voogt, J. M., \& Pieters, J. M. (2011). Internship in vocational education and training: Stakeholders' perceptions of its organisation. Journal of Vocational and Training, 63(4), 575-592.

Akyeampong, K. (2010). 50 years of educational progress and challenge in Ghana. University of Sussex: CREATE.

ASET. (2009). A good practice guide for placement and other work-based learning opportunities in higher education - good practice for placements guides (Vol. 2). Sheffield, England: ASET.

Aston University Careers and Employability Centre. (2009). Placements and internships in Europe. Birmingham, England: Career and Employability Centre.

Ayers, K. (2007). A strategy for internship-seeking sport management students. The SMART Journal, 4(1), 84-90.

Bakar, M. J. A., Harun, R. J., Yusof, K., \& Tahir, I. M. (2011). Business and accounting students' perceptions on industrial internship program. Journal of Education and Vocational Research, 1(3), 72-79.

Bascia, N. (2005). Teacher unions and educational reform. In M. Fullan (Ed.), Handbook of Educational Change (pp. 225-245). The Netherlands: Springer.

Beck, J. E. (1994). The new paradigm of management education: Revolution and counterrevolution. Management Learning, 25(2), 231-247.

Beggs, B., Ross, C. M., \& Goodwin, B. (2008). A Comparison of student and practitioner perspectives of the travel and tourism internship. Journal of Hospitality, Leisure, Sport and Tourism Education, 7(1), 31-39.

Beggs, B. A., Ross, C. M., \& Knapp, J. S. (2006). Internships in leisure services: An analysis of student and practitioner perceptions and expectations. Schole, 21, 1-20.

Ben-Perez, M. (1990). The teacher-curriculum encounter: Freeing teachers from the tyranny of texts. Albany, NY: State University of New York Press.

Billett, S. R. (1994). Situated learning-A workplace experience. Australian Journal of Adult and Community Education, 34(2), 112-130.

Billett, S. (2001) Learning through work: Workplace affordances and individual engagement. Journal of Workplace Learning, 13(5), 209-214. 
Billett, S. (2004). Workplace participatory practices: Conceptualising workplaces as learning environments. Journal of Workplace Learning, 16(6), 312-24.

Billett, S. (2006). Constituting the workplace curriculum. Journal of Curriculum Studies, 38(1), 31-48.

Billett, S. R., \& Rose, J. (1996). Developing conceptual knowledge in the workplace. In J. Stevenson (Ed.), Learning in the workplace: Tourism and hospitality (pp. 204-228). Brisbane, Australia: Griffith University.

Blackwell, P. (2003). Developing departments. In P. Blackwell, \& P. Blackmore (Eds.), Towards strategic staff development in higher education (pp. 119-130). Buckingham, England: SRHE/Open University Press.

Blankstein, A. (2004). Failure is not an option: Six principles that guide student achievement in highperforming schools. Thousand Oaks, CA: Corwin Press.

Blokhuis, F. T. L., \& Nijhof, W. J. (2008). Evidence-based design of workplace learning. In W. J. Nijhof, \& L. F. M. Nieuwenhuis (Eds.), The learning potential of the workplace (pp. 163180). Rotterdam: Sense Publishers.

Boateng, K., \& Ofori-Sarpong, E. (2002). An analytical study of the labour market for tertiary graduates in Ghana. Accra, Ghana: World Bank/National Council for Tertiary Education \& the National Accreditation Board Project.

Bogdan, R., \& Biklen, R. C. (1992). Qualitative research for education: An introduction to theory and methods. Boston, MA: Allyn-Bacon.

Borko, H. (2004). Professional development and teacher learning: Mapping the terrain. Educational Research, 33(8), 3-15.

Borkowski, S. (2008). Internships for high school students. FastWeb, A Monster Company. University of South Florida: A Program of Union Pacific Foundation.

Brown, J. S., Collins, A., \& Duguid, P. (1989). Situated cognition and the culture of learning. Educational Researcher, 18(1), 32-42.

Busby, G. (2003). Tourism degree internships: A longitudinal study. Journal of Vocational Education and Training, 55, 319-334.

Busby, G. D., \& Gibson P. (2010). Tourism and hospitality internship experiences overseas: British perspective. Journal of Hospitality, Leisure, Sport and Tourism Education, 9(1), 4-12.

Carlgren, I. (1999). Professionalism and teachers as designers. Journal of Curriculum Studies, 31(1), 43-56.

Carlin, A., \& Manson, D. (2007). My school, my teacher: A polytechnic approach to information assurance. Communication of the IIMA, 7(3), 65-78.

Cecil, A. K, Fu, Y., \& Jones, E. (2010). Monitoring student success: A systemic model for hospitality and tourism education. International CHRIE Conference-Refereed Track. Paper 10.

Christou, E. S. (1999). Hospitality management education in Greece: An exploratory study. Tourism Management 20, 683-691.

Clandinin, D. J., \& Connelly, F. M. (1992). Teacher as curriculum maker. In P. Jackson (Ed.), Handbook of research in curriculum (pp. 363-401). New York, NY: MacMillan.

Clark, G., \& Whitelegg, J. (1998). Maximising the benefits from work-based learning: The effectiveness of environmental audits. Journal of Geography in Higher Education, 22, 325-334.

Clark, S. C. (2003). Enhancing the educational value of business internships. Journal of Management Education 27(4), 472-484. 
Cohen, L., Manion, L., \& Morrison, K. (2007). Research methods in education. London, England: Routledge.

Collins, A. B. (2001). Gateway to the real world, industrial training: Dilemmas and problems. Tourism Management, 23, 93-96.

Collins, A., Joseph, D., \& Bielaczyc, K. (2004). Design research: Theoretical and methodological issues. Journal of the Learning Sciences, 13(1), 15-42.

Cook, S. J., Parker, R. S., \& Pettijohn, C. E. (2004). The perceptions of interns: A longitudinal case study. Journal of Education for Business, 79(3), 179-185.

Crnković-Pozaić, S. (2006). Transition from school to work: Internships and first entry to the labour market in Croatia. Bureau of Labour Statistics.

Crossley, J. C., Jamieson, L. M., \& Brayley, R. E. (2007). Introduction to commercial recreation and tourism: An entrepreneurial approach (5 $5^{\text {th }}$ ed.). Champaign, IL: Sagamore Publishing.

Darling-Hammond, L., \& Snyder, J. (1992). Curriculum studies and the traditions of inquiry: The scientific tradition. In P. Jackson (Ed.), Handbook of research in curriculum (pp. 41-78). New York: MacMillan.

Datnow, A., \& Stringfield, S. (2000). Working together for reliable school reform. Journal of Education for Students Placed at Risk, 5(1-2), 183-204.

Dee, J. R., Henkin, A. B., \& Singleton, C. A. (2006). Organizational commitment of teachers in urban schools: Examining the effects of team structures. Urban Education, 41, 603-627.

Deketelaere, A., \& Kelchtermans, G. (1996). Collaborative curriculum development: An encounter of different professional knowledge systems. Teachers and Teaching: Theory and Practice, 2(1), 71-85.

De Kock, A., Sleegers, P., \& Voeten, M. J. M. (2005). New learning and choices of secondary school teachers when arranging learning environments. Teaching and Teacher Education, 21, 799-816.

Denton, J. W., Kleist, V. F., \& Surendra, N. (2005).Curriculum and course design: A new approach using quality function deployment. Journal of Education for Business, 111-117.

Divine, R., Linrud, J., Miller, R., \& Wilson, J. H. (2007). Required internships in marketing: Benefits, challenges and determinants of fit. Marketing Education Review 17(2), 45-52.

Dixon, M. A., Cunningham, G. B., Sagas, M., Turner, B. A., \& Kent, A. (2005). Challenge is key: An investigation of affective organizational commitment in undergraduate interns. Journal of Education for Business, 80(3), 172-180.

Domask, J. J. (2007). Achieving goals in higher education: An experiential approach to sustainability studies. International Journal of Sustainability in Higher Education, 8(1), 53-68.

Doyle W., \& Ponder G. A. (1975). The practicality ethic in teacher decision-making. Interchange, 8(3), 1-12.

Durrant, J., \& Holden, G. (2006). Teachers leading change. London, England: SAGE.

Effah, P. (Ed.). (2001). Technical report series. Accra, Ghana: Adwinsa Publications Ghana Ltd.

Effah, P. (2005). A decade of polytechnic education in Ghana: An assessment of achievements and failures. Proceedings of the first Sunyani Polytechnic lecture series 1, 17-29.

Erickson, G., Brandes, G. M., Mitchell, I., \& Mitchell, J. (2005). Collaborative teacher learning: Findings from two professional development projects. Teaching and Teacher Education, 21(7), 787-798. 
Fernandez, C. (2005). Lesson study: A means for elementary teachers to develop the knowledge of mathematics needed for reform-minded teaching? Mathematical Thinking and Leaning, 7, 265-289.

Flagg, B. N. (1990). Formative evaluation for educational technologies. Hillsdale, NJ: Lawrence Erlbaum Associates.

Florida Gulf Coast University. (2009). Florida Gulf Coast University Resort \& Hospitality Management Student Internship Manual. Florida, FL.

Friedman, V. J. (1997). Making schools safe for uncertainty: Teams, teaching, and school reform. Teachers College Record, 99(2), 335-370.

Fullan, M. (2007). The new meaning of educational change (4th ed.). New York, NY: Teachers College Press.

Gervedink Nijhuis, C., Bakah, M. A. B., \& Akomaning, E. (2009). Leadership challenges involved in managing institutional and curriculum changes in polytechnics. In $W$. Kouwenhoven, G. Oduro, \& K. Nsiah-Gyabaah (Eds.), Trends in polytechnic education in Ghana (pp. 85-100). Amsterdam, The Netherlands: Vrije Universiteit.

Ghana Tourist Board. (2005). Ghana Tourism Statistical Factsheet. Accra, Ghana: GTB.

Ghana Tourist Board. (2009). Ghana Tourism Statistical Factsheet. Accra, Ghana: GTB.

Gillim, M. (2006). Putting the pieces together: Effective characteristics of an HR internship program. Senior Honors Theses, Paper 60. Eastern Michigan University.

Girdwood, A. (1999). Tertiary education policy in Ghana, an assessment: 1988-1998. Washington, DC: World Bank.

Goeldner, R., \& Ritchie, J. R. B. (2006). Tourism: principles, practices, philosophies (10 th ed.). Hoboken, NJ: John Wiley and Sons, Inc.

Grossman, P., Wineburg, S., \& Woolworth, S. (2001). Toward a theory of teacher community. Teacher College Record, 103(6), 942-1012.

Guskey, T. R. (2000). Evaluating professional development. Thousand Oaks, CA: Corwin Press.

Hager, P. (1998). Understanding workplace learning: General perspectives. In D. Bound (Ed.), Current issues and new agendas in workplace learning (pp. 30-42). Adelaide, Australia: National Centre for Vocational Education Research.

Handelzalts, A. (2009). Collaborative curriculum development in teacher design teams. Doctoral dissertation. Enschede, The Netherlands: University of Twente.

Hargreaves, A. (2003). Teaching in the knowledge society. Education in the age of insecurity. New York, NY: Teachers College Press.

Harris, A. (2005). Leading or following educational change. School Leadership andManagement, 25(5), 417-419.

Harris, K. J., \& Zhao, F. (2004). Industry internships: Feedback from participating faculty and industry executives. International Journal of Contemporary Hospitality Management, 16(7), 429-435.

Hartley, J. (2004). Case study research. In C. Cassell, \& G. Symon (Eds.), Essential guide to qualitative methods in organizational research (pp. 323-333). London, England: Sage Publications. 
Hasbullah, H., \& Sulaiman, S. (2002, August). Industrial internship programme at University Technology Petronas - A collaboration strategy that enhanced students' soft skills in the everchanging technology. A paper presented at International Conference on Engineering Education. Manchester, England.

Hattie, J. (2003). Teachers make a difference: What is the research evidence? Australian Council for Education Research, 1-17.

Havnes, A. (2009). Talk, planning and decision--making in interdisciplinaryteacher teams: A case study. Teachers and Teaching, 15(1), 155-176.

Heath, R. R. (2010). Ensuring preservice teachers' readiness to teacher standard-based curricula. North Carolina Middle School Association Journal, 2(25), 1-9.

Heppell, M. (2004). How to be brilliant. London, England: Pearson-Prentice Hall.

Hirsh, S., \& Killion, J. (2007). The learning educator: A new era in professional learning. Oxford, OH: NSDC.

Hodges, D., \& Burchell, N. (2003). Business graduate competencies: Employers' views on importance and performance. Asia-Pacific Journal of Cooperative Education, 4(2), 16-22.

Hord, S., \& Sommers, W. (2008). Leading professional learning communities. Thousand Oaks, CA: Corwin Press.

Hughes, J. (2009). The employability strategy June 2009. Portsmouth, England: University of Portsmouth.

Illeris, K. (2003). Workplace learning and learning theory. Journal of Workplace Learning, 15(4), 167-178.

Internship USA (2008). Internship. Bangkok, Thailand: Overseas Educational Group Co. Ltd.

Japan International Cooperation Agency. (2001). The study for the development of a master plan to strengthen technical education in the republic of Ghana. Final Report, pp. 1-150. Accra, Ghana: Ministry of Education.

Johnston, H. (2008). Internships for high school students. The principal partnership: A program of Union Pacific Foundation. University of South Florida.

Johnson, N. A. (1993). Reconsidering curriculum development - A framework for cooperation. Interchange, 24(4), 409-433.

Karukstis, K., \& Elgren, T. (2007). How to design, implement, and sustain a research-supportive undergraduate curriculum. Washington, DC: Council on Undergraduate Research.

Kay, C., \& DeVeau, L. T. (2003). A survey of lodging executives' views on internship programs and cooperatives. Journal of Hospitality \& Tourism Education, 15(2), 24-29.

Kay, C., \& Russette, J. (2000). Hospitality management competencies. The CornellHotel and Restaurant Administration Quarterly, 41(2), 52-61.

Kessels, J., \& Plomp, T. (1999). A systematic and relational approach to obtaining curriculum consistency in corporate education. Journal of Curriculum Studies, 31(6), 679-709.

Keynote Project. (2002). An employer guide to successful work placement. London, England: The Nottingham Trent University.

Kliknaite, S. (2009). How symbiotic industry-university collaboration contributes to the knowledge economy. Paper presented at the Summer Conference 2009, CBS, Denmark, June 17.

Ko, W. (2008). Training, satisfaction with internship programs, and confidence about future careers among hospitality students. Journal of Teaching in Travel \& Tourism, 7(4), 1-15. 
Kolodner, J. L., Camp, P. J., Crismond, D., Fasse, B., Gray, J., Holbrook, J., et al. (2003). Problem-based learning meets case-based reasoning in the middle-school science classroom: Putting learning by design (TM) into practice. Journal of the Learning Sciences, 12(4), 495-547.

Kuiper, W., Nieveen, N., \& Visscher-Voerman, I. (2004). Curriculum development from a technical-professional perspective. In J. van den Akker, W. Kuiper, \& U. Hameyer (Eds.), Curriculum landscapes and trends (pp. 177-198).Dordrecht, The Netherlands: Kluwer.

Kusluvan, S., \& Kusluvan, Z., (2000). Perceptions and attitudes of undergraduate tourism students towards working in the tourism industry in Turkey. Tourism Management, 21, 251-269.

Lam, T., \& Ching, L. (2007). An exploratory study of an internship program: The case of Hong Kong students. Hospitality Management 26, 336-351.

Lam, T., \& Xiao, H. (2000). Challenges and constraints of hospitality and tourism education in China. International Journal of Contemporary Hospitality Management 12(5), 291-295.

Lave, J., \& Wenger, E. (1991). Situated learning: Legitimate peripheral participation.Cambridge, England: Cambridge University Press.

League of Oregon Cities. (2009). Enrollment management and student affairs: Career center. Portland, OR: Portland State University.

Lee, S. A. (2007). Increasing student learning: A comparison of students' perceptions of learning in the classroom environment and their industry-based experiential learning assignments. Journal of Teaching in Travel \& Tourism, 7(4), 37-54.

Leslie, D., \& Richardson, A. (2000). Tourism and cooperative education in UK undergraduate courses: Are the benefits being realised? Tourism Management, 21, 489-498.

Levesque, K., Lauen, D., Teitelbaum, P., Alt, M., \& Librera, S. (2000). U.S. Department of Education. National Center for Education Statistics. Vocational Education in the United States: Toward the Year 2000, NCES 2000-029, Washington, DC.

Lewis, A. (2004, December). Rationalising a tourism curriculum for sustainable tourism development in small Island States: A stakeholder perspective. Paper presented at a conference on Critical Issues in Tourism Education of the Association for Tourism in Higher Education, Missenden Abbey, Buckinghamshire UK.

Little, J. W. (1990). The persistence of privacy: Autonomy and initiative in teachers' professional relations. Teachers college record, 91(4), 509-536.

Lombard, M., Snyder-Duch, J., \& Bracken, C. C. (2002). Content analysis in mass communication: Assessment and reporting of intercoder reliability. Human Communication Research, 28(4), 587-604.

Lyons, F. (2006). Open forum: Excellence and innovation in teaching and learning practice at University of Portsmouth. A paper presented to Excellence and innovation in teaching and learning practice: Experiences from the UK. Melbourne, Australia: Footscray Park.

Marsh, C. J., \& Willis, G. (2003). Curriculum alternative approaches, ongoing issues ( $3^{\text {rd }}$ ed.). New Jersey, NJ: Pearson Education.

McCuddy, M., \& Pirie, W. (2007). Implementing and sustaining educational innovations. Educational Innovation in Economics \& Business, 10(2), 131-148.

McKenney, S., Nieveen, N., \& van den Akker, J. (2006). Design research from a curriculum perspective. In J. van den Akker, K. Gravemeijer, S. McKenney, \& N. Nieveen (Eds.), Educational design research (pp. 67-90). London, England: Routledge. 
McManus, A., \& Feinstein, A.H. (2008). Internships and occupational socialization: What are students learning? Developments in business simulation and experiential learning, 35, 128-137.

Mihail, D. M. (2006). Internship at Greek Universities: An exploratory study. Journal of Workplace Learning 18, 28-41.

Miles, M. B., \& Huberman, A. M. (1994). Qualitative data analysis: An expanded sourcebook ( $2^{\text {nd }}$ ed.). London, Engeland: Sage.

Muthusamy, S., Wheeler, J., \& Simmons, B. (2005). Self-managing work teams: Enhancing organizational innovativeness. Organizational Development Journal, 23(3), 53-66.

NAB. (2009, December). Accredited tertiary institutions. Accra, Ghana: National Accreditation Board.

Neuendorf, K. A. (2002). The content analysis guidebook. Thousand Oaks, CA: Sage.

Newmann, F. M., \& Wehlage, G. G. (1995). Successful school restructuring: A report to the public and educators. Washington, DC: American Federation of Teachers.

Nieveen, N. (2009). Formative evaluation in educational design research. In T. Plomp, \& N. Nieveen (Eds.), In an introduction to educational design research. (pp. 89-101). Enschede, The Netherlands: Axis Media-ontwerpers.

Nsiah-Gyabaah, K. (2005). Polytechnic education in Ghana: The past, the present and the future. Paper presented at NPT/UCC at The kick-off Conference on Building Management and Leadership Capacity in Polytechnics, UCC 20-22 May, Cape Coast.

OXIA Ghana Limited. (2004). Business response to technical and vocational education and training in Ghana. Shaping Future Employable Skills. Industrial attachment strategy.

Pea, R. D. (1993). Learning scientific concepts through material and social activities: Conversational analysis meets conceptual change. Educational Psychologist, 28(3), 265-277.

Pedler, M. (1974). Learning in management education. Journal of European Training, 3(3), 82-94.

Penuel, W. R., Fishman, B. J., Yamaguchi, R., \& Gallagher, L. P. (2007). What makes professional development effective? Strategies that foster curriculum implementation. American Educational Research Journal, 44(4), 921-958.

Pertuzẻ, J. A., Calder, E. S., Greitzer, E. M., \& Lucas, W. A. (2010). Best practices for industryuniversity collaboration. Summer 2010 MIT Sloan Management Review, 51(4), 83- 90.

Petrillose, M. J., \& Montgomery, R. (1998). An exploratory study of internship practices in hospitality education and industry's perception of the importance of internships in hospitality curriculum. Journal of Hospitality \& Tourism Education, 9(4), 46-51.

Plomp, T. (2009). Educational design research: An introduction. In T. Plomp, \& N. Nieveen (Eds.), In an introduction to educational design research (pp. 9-35). Enschede, The Netherlands: Axis Media-ontwerpers.

PNDC Law 321. (1992). Polytechnic law, pp. 1-10.

Postmes, T., Tanis, M., \& DeWit, B. (2001). Communication and commitment in organizations: A social identity approach. Group Processes and Intergroup Relations, 4(3), 227-246.

Quality Assurance Agency. (2007). Code of practice for the assurance of academic quality and standards in higher education. Section 9: Work-based and placement learning. Mansfield, England: QAA.

Reichstetter, R. (2006). Defining a professional learning community. E \& R Research Alert, Report No. 06.05.

Republic Polytechnic. (2008). Placement services for employers. Singapore: Republic Polytechnic.

Resnick, L. (1987). Learning in school and out. Educational Researcher, 16(9), 13-20. 
Riordan, G. (2001). Teachers working together. The Practising Administrator, 23(1), 6-10.

Robinson, J. S. (2006). Graduates' and employers' perceptions of entry-level employability skills needed by agriculture, food and natural resources graduates. Unpublished doctoral dissertation. Columbia, MO: University of Missouri.

Rock, T. C., \& Wilson, C. (2005). Improving teaching through lesson study. Teacher Education Quarterly, 32(1), 77-92.

Rogoff, B. (1995). Observing socio-cultural activity on three planes: Participatory appropriation, guided participation, apprenticeship. In J. W. Wertsch, A. Alvarez, \& P. del Rio (Eds.), Socio-cultural studies of mind (pp. 1-8). Cambridge, England: Cambridge University Press.

Rothman, M. (2007). Lessons learned: Advice to employers from interns. Journal of Education for business, 82(3), 140-144.

Sackney, L., Mitchell, C., \& Walker, K. (2005). Building capacity for learning communities: A case study of fifteen successful schools. Paper presented at the American Education Research Association annual meeting.

Sadler-Smith, E., Down, S., \& Lean, J. (2000). “Modern” learning methods: Rhetoric and reality. Personnel Review, 29(4), 474-490.

Sangster, A., Maclaran, P., \& Marshall, S. (2000). Translating theory into practice: Facilitating work-based learning through IT. Innovations in Education and Training International, 37(1), 50-58.

Schappert, M. (2005). Employers' internship toolkit. Syracuse, NY : Le Moyne College.

Scribner, J. P., Sawyer, R. K., Watson, S. T., \& Myers, V. L. (2007). Teacher teams and distributed leadership: A study of group discourse and collaboration. Educational Administration Quarterly, 43(1), 67-100.

Simmie, G. M. (2007). Teacher design teams (TDTs) - building capacity for innovation, learning and curriculum implementation in the continuing professional development of in career teachers. Irish Educational Studies, 26(2), 163-176.

Skilbeck, M. (1998). School based curriculum development. In A. Hargreaves, A. Lieberman, M. G. Fullan, \& D. Hopkins (Eds.), International handbook of educational change (pp. 121144). Dordrecht, The Netherlands: Kluwer Academic Publishers.

Szambowski, D. J., Szambowski, L. B., \& Samenfink, W. H. (2002). The reality approach to educating hospitality managers: An Australian model. Journal of Hospitality E Tourism Education, 14(2), 53-58.

Taba, H. (1962). Curriculum development, theory and practice. New York, NY: Harcourt Brace.

Tamale Polytechnic. (2007). Programme for second congregation. Tamale, Ghana: GILLBT Press.

Thiel, G. R., \& Hartley, N. T. (1997). Cooperative education: A natural synergy between business and academia. Sam Advanced Management Journal, (62), 19-24.

Tse, T. S. M. (2010). What do hospitality students find important about internships? Journal of Teaching in Travel \& Tourism, 10(3), 251-264.

University of Pittsburgh (2009). 2009-2010 Internship report. Pittsburgh, PA: Office of Student Employment and Placement Assistance (SEPA).

Van den Akker, J. (1999). Principles and methods of development research. In J. van den Akker, R. Branch, K. Gustafson, N. Nieveen, \& T. Plomp, (Eds.), Design approaches and tools in education and training (pp. 1-14). Dordrecht: Kluwer Academic Publishers. 
Van den Akker, J. J. H. (2003). Curriculum perspectives: An introduction. In J. J. H. van den Akker, W. Kuiper, \& U. Hameyer (Eds.), Curriculum landscapes and trends (pp. 1-10). Dordrecht, The Netherlands: Kluwer Academic Publishers.

Van den Akker, J. (2005). Curriculum development re-invented: Evolving challenges for SLO. In J. Letschert (Ed.), Curriculum development re-invented (pp. 16-31). Proceedings of the invitational conference on the occasion of 30 years SLO 1975-2005. Enschede, The Netherlands: SLO.

Van den Akker, J., Gravemeijer, K., McKenney, S., \& Nieveen, N. (Eds.). (2006). Educational design research. London, England: Routledge.

Van den Akker, J., \& McKenney, S. (2004). How can development research improve science curriculum policies and practices? Presentation at the NARST annual meeting, 1-4 April, Vancouver.

Villegas-Reimers, E. (2003). Teacher professional development: An international review of the literature. Paris, France: IIEP-UNESCO.

Visscher, A. J., \& Witziers, B. (2004). Subject departments as professional communities? British Educational Research Journal 30(6), 785-800.

Von Glasersfeld, E. (1987). Learning as a constructive activity. In C. Janvier (Ed.), Problems of representation in the teaching and learning of mathematics (pp. 3-18). Hillsdale, NJ: Lawrence Erlbaum.

Voogt, J., Westbroek, H., Handelzalts, A., Walraven, A., McKenney, S., Pieters, J., \& de Vries, B. (2011). Teacher learning in collaborative curriculum design. Teaching and Teacher Education, 27, 1235-1244.

Waddoups, G. L., Wentworth, N., \& Earle, R. (2004). Principles of technology integration and curriculum development: A faculty design team approach. Computers in the Schools, $21(1 / 2), 15-23$.

Walker, D. F. (2003). Fundamentals of curriculum (2nd ed.). New Jersey, NJ: Lawrence Erlbaum Associates Publishers.

Walo, M. (2001). Assessing the contribution of internship in developing Australian tourism and hospitality students' management competencies. Asia-Pacific Journal of Cooperative Education 2(1), 21-28.

Waryszak, R. Z. (2000). Before, during and after: International perspective of students' perceptions of their cooperative education placements in the tourism industry. Journal of Cooperative Education 35(2/3), 84-94.

Weindling, D. (2005). Teachers as collaborative professionals. London, England: ATL the education union.

Wentz, E. A., \& Trapido-Lurie, B. (2001). Structured college internships in geographic education. Journal of Geography, 100(4), 140-144.

Westbroek, H. B., de Vries, B., Walraven, A., Handelzalts, A., Voogt, J. M., Pieters, J. M., \& McKenney, S.E. (Submited). Teacher involvement in collaborative design: Conceptually informed, but empirically based? Educational Research Review.

Williams, E. A., Duray, R., \& Reddy, V. (2006). Teamwork orientation, group cohesiveness, and student learning: A study of the use of teams in online distance education. Journal of Management Education, 30, 592-616.

Wilson, P. H., Strutton, D., \& Farris, II, M. T. (2002). Investigating the perceptual aspect of sales training. The Journal of Personal Selling \& Sales Management, 22(2), 77-111. 
Yin, R. K. (2003). Case study research: Design and methods (3 ${ }^{\text {rd }}$ ed.). Thousand Oaks, CA: Sage Publications.

Youth Forum Jeunesse. (2009). Opinion paper on internships. Adopted by the Council of Members/Extraordinary General Assembly: Brussels, Belgium, 8-9 May 2009. 


\section{ENGLISH SUMMARY \\ Improving student internship through collaborative curriculum design in Ghanaian Polytechnics}

\section{INTRODUCTION TO THE RESEARCH}

The polytechnic institutions in Ghana are required to provide hands-on training with the necessary skills and competencies to students to meet the middle level manpower needs of industry. In order to fulfil this mandate, a student internship programme is an integrated part of the training of students so as to equip them to transit smoothly from school to the world of work. However, the existing internship programmes were unstructured and unsystematic and unable to equip the students with the required practical skills (Effah, 2005). Given the career-focused orientation of polytechnics graduates should be prepared for the world of work.

Research identifies relevant conditions that contribute to the benefits derived from internships. These conditions, when well-managed, could create an authentic learning environment in the workplace for students. These conditions are: collaboration between school and industry, placement procedures, duration and time), and assessment procedures, and will culminate in the manner in which implementation is carried out.

The purpose of the study was to investigate how collaborative curriculum design (CCD) in design teams of polytechnic instructors contributed to the design of curriculum materials aimed to improve student internship practices in the Departments of Hotel Catering and Institutional management (HCIM) in Ghana's polytechnics. 


\section{RESEARCH DESIGN AND QUESTIONS}

The central question for the study was framed as follows. In which ways does collaborative curriculum design in design teams contribute to quality curriculum materials for sustainable student internship practices in the polytechnics? In addressing this question, a design-based research approach was adopted and four subquestions were framed.

1. What are the perceptions and suggestions among the various key stakeholders of HCIM education regarding student internship and its organisation?

2. Does collaborative curriculum design in design teams contribute to an improved curriculum for student internship?

3. Do the curriculum materials produced by the design teams contribute to renewed student internship according to the stakeholders involved?

4. To what extent does collaborative curriculum design lead to sustainable student internship practices according to the various stakeholders?

\section{RESULTS}

\section{Needs and context analysis}

The purpose of needs and context analysis (research question 1) was to investigate the state of organising student internship in the polytechnics so as to identify the challenges faced by students and suggestions from stakeholders (students, teachers, alumni, industry personnel and management representatives) to improve internship. Outcomes revealed three conditions for successful internship of the polytechnics: (i) Strengthening industry-polytechnic links, (ii) Increasing relevance of placement to interns' academic program, and (iii) Practicing all aspects of the field during student internship program.

Additionally, challenges were identified in the organisation of internship: (i) no curriculum materials to guide internship, (ii) polytechnic-industry collaboration was episodic, (iii) difficulty in getting placement, (iv) lack of full participation by students, (v) students assigned to menial duties in one section of industry, (vi) supervision was poorly carried out by teachers and industry-based supervisors, (vii) shorter time spent in internship, and (viii) unfriendly nature of industry workers towards students. 
Besides these challenges, stakeholders expressed preparedness to contribute to improved student internship. Suggestions made by stakeholders for improvement in student internship were as follows: (i) hospitality industry redoubling its support in the training of students, (ii) extension of internship period, and (iii) teachers' active involvement in internship, and (iv) closer collaboration among stakeholders.

\section{First design and implementation study}

The Department of HCIM at Tamale Polytechnic was the site for the first design and implementation study (research question 2). Teachers in the Department of HCIM formed two design teams to collaborate in the design of curriculum materials for student internship having inculcated inputs from students and industry representatives. The inputs of students and industry were imperative because they are key stakeholders of the hospitality management program. The design teams collaborated in designing the curriculum materials for eight weeks. Final curriculum materials were distributed to all students, teachers and hospitality industry where students went for internship.

The outcomes of the study were as follows: the teachers' perceptions about the CCD in design teams were positive throughout the entire study period. Teachers reported that their involvement in design teams was worthwhile. There were also improvements in internship practices: the number of students participating in student internship had increased; lengthier time spent by interns; interns served in various sections of the industry; interns achieved their expected objectives; industry workers cooperated with interns and the supervision of interns by industry had improved. The self-assessed competencies (in food production, restaurant service, housekeeping and front office) of students who embarked on internship (trained) were higher than those who did not (untrained). Moreover, the trained students and industry were quite satisfied with their activities during internship. Polytechnic's link with industry and teachers' active involvement in internship still needed to be strengthened, and teacher supervision of students was absent.

\section{Second design and implementation study}

Takoradi Polytechnic was the study site for the second design and implementation phase of the research project which addresses research question 3. Teachers invited suggestions from industry representatives and students in the preparation of the curriculum materials for student internship. Teachers used 
their rich experiences in the industry coupled with the use of relevant materials to design the curriculum materials. Teachers collaborated in teams endeavouring that the final curriculum materials were of quality in terms of consistency, practicality and effectiveness. Teachers, students and industry personnel concurred with the practical usefulness of the curriculum materials in the training of students. The outcomes of student self-assessed competencies and industrybased assessment were commendable. Stakeholders acknowledged the curriculum materials as a guide to students' training, providing prior knowledge to both industry and students as to what roles were expected of them.

Internship practices improved in the areas of supervision, workers cooperating with interns, job rotation, and work assigned to interns were challenging and meaningful. Generally, students improved their competencies in all the four core areas of the hospitality industry where they served during internship. Stakeholders were satisfied with student competencies gained during the internship. Industry assessment of students was very satisfactory; connoting students' gradual smooth transition to the world of work. The improvement in competencies of students could be partly due to the use of curriculum materials. Other improvements, not linked directly with curriculum materials were duration for internship, placement and participation of interns. They could be due to the gradual improvement in the relationship between the polytechnic and industry which was also a result of the active involvement of the industry in the design of the curriculum materials.

Contrary to the results of the needs and context study, teachers were satisfied with the polytechnic's links with industry. Their initial aloofness changed into enthusiasm after they were involved in the CCD process. To effectively involve teachers in internship supervision, the polytechnic should endeavour to enrol more teachers in the internship supervision team and should continue to improve its collaboration with industry. The study confirms other studies about improvement in student competencies through improved internship practices. It also empirically endorses curriculum implementation strategies which advocate teachers' involvement in curriculum innovation processes.

\section{Impact study}

The purpose of this study was to explore the extent to which the teachers in the Departments of HCIM of Tamale and Takoradi Polytechnics and management representatives of these polytechnics have continued with the activities of CCD to improve curriculum materials for student internship, and the influence of the 
curriculum materials on the organisation of student internship as well as the opinions of teachers and management on CCD. The fourth research question is addressed in the impact study.

The results of the study indicate that teachers from both Takoradi and Tamale were very positive on $\mathrm{CCD}$ as a means to collaboratively improve curriculum materials. Teachers and management representatives acknowledge curriculum development as part of teacher's role particularly in tertiary educational institutions like the polytechnic. It was identified that CCD in design teams gives rise to shared expertise among teachers, and creates ownership and shared vision on curriculum goals and organisation. Other new emerging constructs that could improve curriculum materials identified were feedback for continuous curriculum improvement and coherence in curriculum objectives as a result of liaising with other stakeholders like students and industry. All such constructs that could improve curriculum materials for student internship are premised on conditions where teachers would value working in teams and management support is guaranteed.

Furthermore the curriculum materials were used by students and industry during internship. The perceptions of Takoradi teachers and students on the influence of the curriculum materials on the organisation of student internship were significantly higher than their counterparts in Tamale probably because teachers from Takoradi were more involved in student internship through supervision than teachers from Tamale. The stakeholders acknowledged that the implementation challenges identified in the context and needs analysis have been partly resolved through the curriculum materials. Teachers and industry identified the use of the curriculum materials as a pivotal factor in improving student internship practices and in improving polytechnic-industry collaboration. However, industry cooperation and support of students needed to be strengthened as well as teacher and management representative supervision particularly in Tamale.

Finally, both teachers and management representatives were positive toward $\mathrm{CCD}$ as a means of ensuring improved curriculum in the polytechnics. CCD offers the opportunity for teachers to discuss issues pertaining to content and pedagogical knowledge as well as skills and techniques in hospitality management which eventually results in improved student learning. 


\section{OVERALL CONCLUSIONS}

The motivation for this research centred on the gradual transformation of unstructured to structured student internship through collaborative design of curriculum materials in design teams of teachers. Through the curriculum materials the organization of student internship has been streamlined so as to better prepare students of the Ghanaian Polytechnics for the hospitality industry. A number of issues emerged that are worth considering in the conclusions.

Perceptions of management representatives, teachers, students, alumni and industry personnel generally did not differ on relevant conditions (collaboration, placement, duration and assessment) that contribute to the benefits derived from well managed internship. Polytechnics collaboration with industry needed to be reinvigorated to foster student internship. Social, economic, technical deficiency and lack of professional commitment were challenges faced by students during internship. Participants identified industry and teachers' active involvement in student internship and extension of time for internship as critical for interns' training.

The utilisation of the curriculum materials in student internship improved internship practices. The self-assessed competencies of students who embarked on internship (trained) were higher than those who did not (untrained). Furthermore, industry personnel were satisfied with the conduct of interns.

To ensure quality of the documents in terms of consistency, practicality and effectiveness all stakeholders need to have input in the design of curriculum materials for student internship. The stakeholders confirmed the practical usefulness of the curriculum materials for the training of students during internship which gave rise to improvement in student self-assessed competencies in hospitality management operations. It was very refreshing that industry-based assessment of interns was commendable; implying students were gradually transiting from school to the world of work. Stakeholders acknowledge and corroborate the curriculum materials guided students' training, providing prior knowledge to both industry and students as to what roles are expected of them. There were marked improvements in internship practices.

Management representatives and teachers of Tamale and Takoradi Polytechnics responded positively to the sustainability of $\mathrm{CCD}$ in design teams as a strategy to improve student internship practices and curriculum materials. The introduction of $\mathrm{CCD}$ had paved a way for teachers to work in teams in designing curriculum materials for student internship. Teachers admitted in the design process in design teams, they learned from each other, received feedback from industry 
where students went for internship thereby improving on the quality of organising internship.

Teachers and management representatives confirmed that students had demonstrated more commitment and seriousness toward internship. Generally, the organisation of student internship in the polytechnics has improved considerably.

\section{RECOMMENDATIONS}

Recommendations are provided for continued exploration of effective adoption and adaptation of CCD in design teams in relation to the design and implementation of quality curriculum documents for sustainable student internship practices. Based on the successful outcomes of this research and on relevant literature, this section is outlined along implications for practice, policy implications and future research.

\section{Implications for practice}

For the curriculum materials designed for student internship to be functional over time, educators should regularly continue to liaise with industry so as to be abreast with current changes in technology as well as needs of industry. The heads of educational institutions should make sure that teachers periodically review the curriculum materials in order to reflect the realities in industry. In view of the gains teachers derived from $\mathrm{CCD}$ in design teams and the willingness expressed by both management representatives and teachers to maintain CCD, the heads of department should be more proactive in ensuring that the activities of design teams in the department are not curtailed. CCD in design teams is a bottom-up approach ensuring that educational reforms are initiated in the departments which needs management support. It is very crucial for the design team as a scheme to become part and parcel of the educational institutions' calendar. Regular teacher collaboration in curriculum activities would enhance teacher competence and eventual improvement in student learning (Borko, 2004) thereby achieving the aim of tertiary education of preparing its products for the world of work. Other tertiary educational institutions that enrol students for internship should endeavour to liaise with the key stakeholders in drawing up curriculum materials to help streamline the activities of interns and industry practitioners in order to ensure that the purpose for which the extended 
programme is instituted is achieved. Guided internship is of paramount importance for all educational institutions organising internship for their students because it is a surest way of ensuring that stakeholders are held accountable.

Implications for policy

The polytechnics should endeavour to award credit hours to student internship. Internship should be considered a requirement for students graduating from the institution. In this vein, students' participation in internship will greatly improve and more seriousness will be attached. CCD in design teams should be embraced by teachers and management of educational institutions because it creates the platform for teachers to interact with one another thereby sharing their professional competence and improving quality of curriculum documents through a systematic manner of analysing the problems, designing and developing, implementing the product designed and evaluating. Such a bottom-up strategy should be part and parcel of educational institutions' timetable because it is a means of empowering teachers to assert themselves as professionals.

Future research

Tertiary institutions could team up with industry personnel to carry out research projects on product designs (other than curriculum materials) through the adoption and adaptation of CCD so as to minimise or close existing gaps that normally exist between industry and educational institutions. Such joint projects could cement the relationship between the two parties and culminate in sharpening the attitudes, knowledge and skills of participants because identification of the gaps and the search for solutions are ways of bringing about improvement in existing phenomenon. Educational institutions with academic programmes perceived to be dysfunctional could adopt CCD to improve on their quality so as to be relevant to stakeholders. Future research can also be directed to the effectiveness of the role stakeholders play in CCD. Their roles can be twofold, participating in the design process, like teachers in our studies, or improving conditions for a successful collaborative design process. 
NEDERLANDSE SAMENVATTING

\section{Het verbeteren van stages van studenten door middel van gezamenlijk ontwerpen van curricula in opleidingen aan Ghanese polytechnics}

\section{INLEIDING}

Van polytechnics in Ghana wordt verwacht dat ze hands-on training leveren voor de studenten om hen de relevante vaardigheden en competenties aan te leren, zodat ze aan de behoeftes van de industrie aan middenmanagement menskracht kunnen voldoen. Een stage maakt een geïntegreerd deel uit van de opleiding van de studenten, zodat ze voldoende zijn toegerust om een soepele overgang te maken van school naar de wereld waarin ze gaan werken. Echter, de bestaande stages zijn ongestructureerd, niet systematisch en niet in staat om de studenten met de benodigde praktische vaardigheden toe te rusten. Gegeven de loopbaangerichte oriëntatie van de polytechnics, zouden afgestudeerden voorbereid moeten worden op de wereld waarin ze gaan werken.

Onderzoek heeft relevante condities geïdentificeerd die bijdragen aan de voordelen die aan stages worden ontleend. Deze condities vormen bij adequate toepassing het ontwerp van een authentieke leeromgeving op de stage-werkplek voor studenten. Deze condities zijn: samenwerking tussen polytechnics en industrie, plaatsingsprocedures, duur en tijd, en assessment procedures. Deze condities zijn vooral bepalend voor de manier waarop de implementatie wordt uitgevoerd.

Het doel van deze studie was om te onderzoeken hoe het gezamenlijk ontwerpen van curricula (collaborative curriculum design; CCD) in ontwerpteams van docenten binnen polytechnics bijdraagt aan het verbeteren van stage-activiteiten van studenten van het Departement van Hotel Catering en Institutioneel Management (GCIM) in polytechnics in Ghana. 


\section{ONDERZOEKSDESIGN EN ONDERZOEKSVRAGEN}

De kernvraag van dit onderzoek werd als volgt ingekaderd: $O p$ welke manier draagt het gezamenlijk ontwerpen van curricula in ontwerpteams bij aan de kwaliteit van curriculum materialen voor duurzame stage-activiteiten voor studenten in polytechnics? Bij het adresseren van deze vraag werd een ontwerpgerichte onderzoeksbenadering gehanteerd en werden vier subvragen opgesteld.

1. Wat zijn de percepties en aanbevelingen van de verschillende belangrijkste stakeholders van HCIM onderwijs ten opzichte van stages van studenten en de organisatie ervan?

2. Levert het gezamenlijk ontwerpen in ontwerpteams een bijdrage aan het verbeteren van een curriculum voor stages van studenten?

3. Leveren de curriculummaterialen, geproduceerd door ontwerpteams, volgens de betrokken stakeholders een bijdrage aan vernieuwde stages van studenten?

4. In welke mate leidt het gezamenlijk ontwerpen van curricula volgens de verschillende stakeholders tot duurzame stage-activiteiten van studenten?

\section{RESULTATEN}

\section{Analyse van behoeften en context}

Het doel van de behoefte- en context-analyse (onderzoeksvraag 1) was om de stand van zaken ten opzichte van het organiseren van stages in de polytechnics te onderzoeken, om na te gaan met welke uitdagingen studenten worden geconfronteerd, en welke aanbevelingen stakeholders (studenten, docenten, alumni, industrieel personeel en vertegenwoordigers van het management) kunnen leveren om de stages te verbeteren. De uitkomsten brachten drie voorwaarden voor succesvolle stages in polytechnics aan het licht: (i) versterking van banden tussen de polytechnics en het bedrijfsleven, (ii) verhoging van de relevantie van de plaatsing in het academische programma van stagiairs, en (iii) oefening in alle aspecten van het werkveld gedurende de stage.

Tevens werden er problemen geïdentificeerd in de organisatie van de stages: (i) geen curriculummaterialen om de stages te begeleiden, (ii) samenwerking tussen de polytechnics en de bedrijven kwam sporadisch voor, (iii) moeilijkheden bij het verkrijgen van stageplaatsen, (iv) gebrek aan volledige deelname door studenten, (v) studenten kregen ondergeschikte taken toegewezen in één bepaalde sectie van 
het bedrijfsleven, (vi) supervisie door docenten en supervisors uit het bedrijfsleven werd slecht uitgevoerd, (vii) verkorting van tijd doorgebracht in stages, en (viii) onvriendelijke bejegening van studenten door werknemers uit het bedrijfsleven.

Naast deze problemen werd door stakeholders de bereidheid geuit om bij te dragen aan het verbeteren van stages. Aanbevelingen die door stakeholders werden gedaan voor het verbeteren van stages waren: (i) de horeca verdubbelt de steun in de training van studenten, (ii) uitbreiding van de stage-periode, (iii) actieve betrokkenheid van docenten bij de stages, en (iv) nauwere samenwerking tussen stakeholders.

\section{Eerste design en implementatie studie}

Het departement van HCIM aan de polytechnic van Tamale was de plaats waar het eerste ontwerp- en implementatie-onderzoek (onderzoeksvraag 2) plaatsvond. Docenten in het departement van HCIM formeerden twee ontwerpteams om samen te werken bij het ontwerpen van curriculum materialen voor stages, daarbij rekening houdend met de input van studenten en vertegenwoordigers van de bedrijven. De input van studenten en het bedrijfsleven was voorwaardelijk omdat zij belangrijke stakeholders zijn in het management programma van de dienstensector. De ontwerpteams werkten acht weken lang aan het ontwerpen van curriculummaterialen. De uiteindelijke curriculummaterialen werden verspreid onder alle studenten en docenten, en onder de bedrijven in de dienstensector waar studenten stage liepen.

De uitkomsten van het onderzoek waren als volgt: de percepties van docenten over CCD in ontwerpteams waren positief gedurende de gehele onderzoeksperiode. Docenten rapporteerden dat hun betrokkenheid in de ontwerpteams de moeite waard was. Er waren ook verbeteringen in de stage praktijken: het aantal studenten dat deelnam aan stages was toegenomen; verlenging van tijd doorgebracht op de stageplaatsen; stagiairs waren werkzaam in verschillende secties van het bedrijfsleven; stagiairs bereikten de door hen verwachte doelen; werknemers uit het bedrijfsleven werkten samen met stagiairs; en de supervisie vanuit het bedrijfsleven van de stagiairs was verbeterd. De door henzelf ingeschatte competenties (in de voedselbereiding, in de bediening in het restaurant, in het huishoudelijk werk, en aan de receptie) van studenten die deelnamen aan een stage (getraind) waren hoger dan die van studenten die dat 
niet deden (ongetraind). Bovendien waren de getrainde studenten en het bedrijfsleven behoorlijk tevreden over hun activiteiten tijdens de stage. Versterking van de band met het bedrijfsleven, en de actieve betrokkenheid van docenten bij de stages lieten echter nog steeds te wensen over, en supervisie van studenten door docenten was geheel afwezig.

\section{Tweede ontwerp en implementatie studie}

De polytechnic van Takoradi was de plaats waar de tweede studie naar de ontwerp- en implementatiefase van het onderzoeksproject plaatsvond (onderzoeksvraag 3). Docenten vroegen om aanbevelingen van vertegenwoordigers van het bedrijfsleven en van studenten bij het voorbereiden van de curriculummaterialen voor de stages. Docenten koppelden hun rijke ervaringen in het bedrijfsleven aan het gebruik van relevante technieken om de curriculummaterialen te ontwerpen. Docenten werkten samen in teams om zich ervan te verzekeren dat de uiteindelijke curriculummaterialen van hoge kwaliteit waren in termen van consistentie, bruikbaarheid en effectiviteit. Docenten, studenten en personeel uit het bedrijfsleven waren het erover eens dat de curriculummaterialen praktisch bruikbaar waren in de training van studenten. De uitkomsten van de door de studenten zelf ingeschatte competenties en die van het bedrijfsleven waren overtuigend. Stakeholders erkenden dat de curriculummaterialen werkten als een gids bij de training van studenten, waarbij voorkennis werd geleverd aan zowel het bedrijfsleven als aan de studenten over welke rol ze verwacht werden te vervullen.

De stages verbeterden op het gebied van supervisie, in de samenwerking tussen werknemers en stagiairs, en in de afwisseling op het werk, en het werk dat aan stagiairs werd toegewezen was uitdagend en betekenisvol. Over het algemeen versterkten studenten hun competenties in alle vier de gebieden van de dienstensector waar zij hun stages vervulden. De stakeholders waren tevreden met de competenties die studenten tijdens hun stages verwierven. De inschatting van de kwaliteit van de studenten door het bedrijfsleven was nauwkeurig en was tevens een goede voorspeller van een soepele overgang van studenten naar de arbeidsmarkt. De versterking van de competenties van studenten kan gedeeltelijk toegeschreven worden aan het gebruik van curriculummaterialen. Andere verbeteringen, niet direct verbonden met curriculummaterialen, waren de duur van de stage, de plaatsing en de deelname van stagiairs. Zij kunnen worden toegeschreven aan de geleidelijke verbetering van de relatie tussen de 
polytechnics en het bedrijfsleven, wat ook gezien kon worden als een resultaat van de actieve betrokkenheid van het bedrijfsleven bij het ontwerpen van de curriculummaterialen.

In tegenstelling tot wat de behoefte- en contextanalyse had aangetoond bleken docenten tevreden te zijn over de banden tussen de polytechnics en het bedrijfsleven. Hun aanvankelijke gereserveerdheid veranderde in enthousiasme nadat ze sterker bij het CCD-proces werden betrokken. Om de docenten effectief te betrekken bij de supervisie van de stage, zou de polytechnic moeten proberen meer docenten in te zetten voor de supervisie van stages, en zou ze de verbetering van de samenwerking met het bedrijfsleven moeten voortzetten. De studie bevestigt resultaten van andere studies over verbetering van competenties van studenten door middel van verbeterde stages. Het levert tevens een empirische onderbouwing voor curriculumimplementatie strategieën die de betrokkenheid van docenten bij het curriculuminnovatie proces voorschrijven.

\section{Impactstudie}

Het doel van deze studie was te onderzoeken in welke mate de docenten op de departementen van HCIM van Tamale en Takoradi Polytechnics en de vertegenwoordigers van het management van deze polytechnics de activiteiten van CCD hebben voortgezet om de curriculummaterialen voor stages te verbeteren, en om de invloed van de curriculummaterialen op de organisatie van stages, evenals de meningen van docenten en management over CCD, te verbeteren. Voor de impactstudie geldt de vierde onderzoeksvraag.

De resultaten van de studie geven aan dat docenten uit zowel Takoradi als Tamale zeer positief waren over CCD als een middel om gezamenlijk de curriculummaterialen te verbeteren. Docenten en vertegenwoordigers van het management erkennen dat het ontwerpen van curricula deel uit maakt van de rol van docent, vooral in tertiaire onderwijsinstituten zoals de polytechnics. Er werd aangetoond dat $\mathrm{CCD}$ in ontwerpteams aanleiding geeft tot het delen van expertise onder docenten, en dat het ervoor zorgt dat mensen zich de doelen en de organisatie van het curriculum toe-eigenen en hun visie op deze doelen delen. Andere nieuwe technieken werden geïdentificeerd, die zouden kunnen zorgen voor een verbetering van de curriculummaterialen, zoals het geven van feedback voor het in stand houden van curriculumverbetering en van coherentie in curriculumdoelen als een gevolg van contact met stakeholders zoals studenten en 
het bedrijfsleven. Al dergelijke technieken, die zorgen voor verbetering van materialen voor stages, gaan ervan uit dat condities worden geschapen waarbij docenten het waarderen om in teams te werken en waar steun vanuit het management is gegarandeerd.

Curriculummaterialen werden in gebruik genomen door de studenten en het bedrijfsleven tijdens de stage. De percepties van de Takoradi docenten en studenten over de invloed van curriculummaterialen op de organisatie van stages waren significant hoger dan die van hun collega's in Tamale, waarschijnlijk omdat docenten van Takoradi meer betrokken waren bij de stages door middel van supervisie dan docenten van Tamale. De stakeholders erkenden dat de problemen met de implementatie, die geïdentificeerd waren in de behoefte- en contextanalyse, gedeeltelijk werden opgelost door middel van de curriculummaterialen. Docenten en het bedrijfsleven identificeerden het gebruik van de curriculummaterialen als een cruciale factor in het verbeteren van stages en het verbeteren van de samenwerking tussen polytechnics en het bedrijfsleven. Echter, de samenwerking met het bedrijfsleven en de steun van studenten zouden nog versterkt moeten worden, evenals de supervisie door een docent en een vertegenwoordiger van het management, vooral in Tamale.

Ten slotte bleek dat zowel docenten als vertegenwoordigers van het management positief waren over CCD als een middel om zich te verzekeren van een verbeterd curriculum in de polytechnics. CCD biedt docenten de gelegenheid om kwesties over inhoud en pedagogische en inhoudelijke kennis, evenals vaardigheden en technieken in het management van de dienstensector te bespreken, wat uiteindelijk leidt tot verbetering in het leerproces van studenten.

\section{ALGEMENE CONCLUSIES}

De motivatie voor dit onderzoek is gecentreerd rond de geleidelijke transformatie van ongestructureerde naar gestructureerde stages door middel van het gezamenlijk ontwerpen van curriculummaterialen in ontwerpteams van docenten. Door het gebruik van curriculummaterialen is de organisatie van stages meer gestroomlijnd, zodat studenten van de Ghanese polytechnics beter voorbereid zijn op het werken in de dienstensector. Een aantal onderwerpen is de moeite waard om te overwegen in deze conclusies. 
Percepties van vertegenwoordigers van het management, docenten, studenten, alumni en personeel van het bedrijfsleven verschillen over het algemeen niet op het gebied van relevante condities (samenwerking, plaatsing, duur en assessment) die bijdragen aan de voordelen die een goed beheerde stage oplevert. De samenwerking tussen polytechnics en het bedrijfsleven moest nieuw leven worden ingeblazen om effectief gebruik van stages aan te moedigen. Sociale, economische, en technische beperkingen en gebrek aan professionele betrokkenheid waren uitdagingen waarmee studenten tijdens hun stage werden geconfronteerd. Deelnemers constateerden actieve betrokkenheid van het bedrijfsleven en docenten bij stages, en verlenging van tijd voor de stage, als zijnde een cruciaal element in de training van stagiairs.

Het gebruik van de curriculummaterialen tijdens stages heeft de stages verbeterd. De zelf ingeschatte competenties van studenten die deelnamen aan stages (getraind) waren hoger dan die van degenen die niet deelnamen (ongetraind). Bovendien was het personeel van het bedrijfsleven tevreden over het gedrag van de stagiairs.

Om de kwaliteit van materialen te verzekeren in termen van consistentie, praktische uitvoerbaarheid en effectiviteit is de input van alle stakeholders nodig bij het ontwerpen van curriculummaterialen voor stages. De stakeholders bevestigden de praktische bruikbaarheid van de curriculummaterialen voor de training van studenten tijdens de stage, wat een verbetering opleverde van de door studenten zelf ingeschatte competenties voor management activiteiten in de dienstensector. Het was erg bemoedigend dat de inschatting door het bedrijfsleven van stagiairs adequaat was; dit hield in dat studenten geleidelijk de overgang konden maken van school naar de wereld van het werk. De stakeholders erkenden en bevestigden dat het curriculummateriaal de training van de studenten effectief begeleidde, en dat het voorkennis bood aan zowel het bedrijfsleven als de studenten over welke rollen van hen verwacht werden. Er traden opvallende verbeteringen op tijdens de stages.

Vertegenwoordigers van het management en docenten van Tamale en Takoradi reageerden positief op de mogelijkheid van een duurzame voortzetting van CCD in ontwerpteams als een strategie om de curriculummaterialen en daardoor de stages te verbeteren. De introductie van CCD had de weg vrijgemaakt voor docenten om in teams te werken aan het ontwerpen van curriculummaterialen voor stages. Docenten namen deel aan het ontwerpproces in teams, zij leerden van elkaar en 
ontvingen feedback van het bedrijfsleven waar studenten naar toe gingen voor stages, waardoor ook de kwaliteit van het organiseren van de stage verbeterde.

Docenten en vertegenwoordigers van het management bevestigden dat studenten meer inzet en serieuze betrokkenheid toonden ten opzichte van de stage. Over het algemeen was de organisatie van stages in de polytechniek aanzienlijk verbeterd.

\section{AANBEVELINGEN}

Aanbevelingen kunnen worden gedaan voor het voortzetten van onderzoek naar effectieve adoptie en adaptatie van CCD in ontwerpteams in relatie tot het ontwerpen en implementeren van curriculumdocumenten ten behoeve van de kwaliteit van duurzame stages. De positieve uitkomsten van dit onderzoek en de relevante onderzoeksliteratuur leveren implicaties voor de praktijk, voor beleid, en voor toekomstig onderzoek.

\section{Implicaties voor de praktijk}

Om de voor stages ontwikkelde curriculummaterialen voor langere tijd functioneel te laten zijn zouden docenten regelmatig contacten moeten leggen met de dienstensector, om zo op de hoogte te kunnen blijven van de veranderingen in technologie en van de behoeften van de dienstensector. Het management van de onderwijsinstituten zouden zich ervan moeten vergewissen dat docenten periodiek de curriculummaterialen herzien om daarin de realiteit van de dienstensector te kunnen reflecteren. In het licht van de winst die CCD in ontwerpteams de docenten heeft opgeleverd en de bereidheid die door zowel de vertegenwoordigers van het management als de docenten werd geuit om CCD voort te zetten, zouden de hoofden van het departement meer proactief moeten zijn om ervoor te zorgen dat de activiteiten van de ontwerpteams in het departement niet verminderd worden. CCD in ontwerpteams is een bottom-up benadering die ervoor zorgt dat onderwijshervormingen worden geïnitieerd in de departementen, waar ondersteuning van het management voor nodig is. Het is erg cruciaal voor het ontwerpteam dat hun activiteiten onderdeel uitmaken van, en worden vermeld op, de curriculumagenda van de opleiding. Regelmatige samenwerking in curriculumactiviteiten zouden de competenties van docenten vergroten en uiteindelijk leiden tot verbetering in het leren van studenten, 
waardoor het doel van tertiair onderwijs behaald zou worden van het voorbereiden van zijn studenten voor de arbeidsmarkt. Andere tertiaire onderwijsinstituten die studenten aanmelden voor stages zouden zich moeten inspannen om contacten op te nemen met de belangrijkste stakeholders in het ontwerpen van curriculummaterialen en zodoende te helpen de activiteiten van stagiairs en praktijkbeoefenaars in het bedrijfsleven te stroomlijnen waarmee het doel waarvoor het uitgebreide programma is opgezet wordt bereikt. Begeleide stage is van het hoogste belang voor alle onderwijsinstituten die stages organiseren voor hun studenten omdat het de meest zekere manier is om ervoor te zorgen dat de stakeholders verantwoording moeten afleggen.

\section{Implicaties voor beleid}

De polytechnics zouden ernaar moeten streven om credits voor stages toe te kennen. Stages zouden gezien moeten worden als een voorwaarde voor afstuderen van studenten aan het instituut. In die geest zal de deelname van studenten aan een stage enorm verbeteren en meer serieus genomen worden. CCD in ontwerpteams zou door docenten en management van onderwijsinstituten omarmd moeten worden omdat het een platform creëert voor interactie tussen docenten waarbij ze hun professionele competenties delen en de kwaliteit van curriculumdocumenten verbeteren door middel van een systematische manier van het analyseren van de problemen, ontwerpen en ontwikkelen van oplossingen, en het implementeren van het ontworpen product, en het evalueren ervan. Een zodanige bottom-up strategie zou op de agenda van de onderwijsinstituten geplaatst moeten worden omdat het een middel is om de docenten in staat te stellen zichzelf als professionals te versterken.

\section{Toekomstig onderzoek}

Tertiaire instituten zouden een team moeten vormen met personeel uit het bedrijfsleven om onderzoeksprojecten uit te voeren over het ontwerp van producten (anders dan curriculummaterialen) door middel van adoptie en adaptatie van CCD, om de bestaande leemtes die in de regel bestaan tussen het bedrijfsleven en het onderwijs te minimaliseren of helemaal op te vullen. Zulke gezamenlijke projecten zouden de relatie tussen de twee partijen bestendigen en dit zou uiteindelijk terug te vinden zijn in de attitudes, kennis en vaardigheden van deelnemers, omdat vaststellen van de leemtes en het zoeken naar oplossingen manieren zijn om verbeteringen tot stand te brengen. Onderwijsinstituten met 
academische programma's die als disfunctioneel kunnen worden gezien zouden CCD kunnen adopteren om de kwaliteit te verbeteren ten einde relevant te zijn voor stakeholders. Toekomstig onderzoek kan ook gericht worden op de effectiviteit van de rol die stakeholders spelen in CCD. Hun rollen kunnen tweeledig zijn, enerzijds de deelname aan het ontwerpproces, zoals docenten in onze studies, anderzijds het verbeteren van condities voor een succesvol gezamenlijk ontwerpproces. 
APPENDICES 


\section{APPENDIX A1}

Teacher questionnaire (Needs and Context)

1. Name of Institution: Gender: Male

[ ] Female []

2. Position in Institution (Department) besides being academic staff:.

3. Qualification: HND [] Diploma [] Bachelors [] Masters [] Other specify.

Please tick $(\sqrt{ })$ the most appropriate option Response

\begin{tabular}{|c|c|c|c|c|c|}
\hline Statement & SD & $\mathrm{D}$ & $\mathrm{N}$ & A & SA \\
\hline \multicolumn{6}{|l|}{$\begin{array}{l}\text { I have a sense of ownership over the national curriculum for HCIM } \\
\text { programme. }\end{array}$} \\
\hline \multicolumn{6}{|l|}{$\begin{array}{l}\text { During the design and development of national curriculum for HCIM, I } \\
\text { feel left out. }\end{array}$} \\
\hline \multicolumn{6}{|l|}{ Internship programme for HCIM students is well organised. } \\
\hline \multicolumn{6}{|l|}{$\begin{array}{l}\text { The time earmarked for internship programme is sufficient for HCIM } \\
\text { students to realize the goals and objectives in the HCIM national } \\
\text { curriculum. }\end{array}$} \\
\hline \multicolumn{6}{|l|}{$\begin{array}{l}\text { The hospitality industry collaborates with teachers of Department of } \\
\text { HCIM in the training of the students. }\end{array}$} \\
\hline \multicolumn{6}{|l|}{$\begin{array}{l}\text { HCIM students find placements in organizations which are related to } \\
\text { their course areas of study during internship. }\end{array}$} \\
\hline \multicolumn{6}{|l|}{ Students are made to write reports on their experience on internship. } \\
\hline \multicolumn{6}{|l|}{ Student internship reports form part of students' assessment. } \\
\hline \multicolumn{6}{|l|}{$\begin{array}{l}\text { Employers are generally satisfied with the job performance of HCIM } \\
\text { students. }\end{array}$} \\
\hline \multicolumn{6}{|l|}{$\begin{array}{l}\text { The hospitality industry does not collaborate with Department of HCIM } \\
\text { in training students. }\end{array}$} \\
\hline \multicolumn{6}{|l|}{$\begin{array}{l}\text { The hospitality industry should redouble their support in the training of } \\
\text { HCIM students. }\end{array}$} \\
\hline \multicolumn{6}{|l|}{$\begin{array}{l}\text { HCIM teachers should actively involve themselves in student internship } \\
\text { programme. }\end{array}$} \\
\hline \multicolumn{6}{|l|}{$\begin{array}{l}\text { There should be closer collaboration between all key stakeholders of } \\
\text { HCIM education in the polytechnic. }\end{array}$} \\
\hline Time for internship programme for HCIM students should be extended. & & & & & \\
\hline
\end{tabular}

4. What is the role of hospitality industry regarding the realization of the national goals and objectives in HCIM curriculum in HCIM students?

5. Please specific other challenges that adversely affect teaching and learning in the Department of HCIM, if any, that you encounter in the process of teaching.

6. In your opinion, who are the key stakeholders of HCIM education?

7. What specific functions do you want the key stakeholders of HCIM to play?

8. Please, what are your suggestions toward improving teaching and learning in the Department of HCIM (Generally)? 


\section{APPENDIX A2}

Management representative questionnaire (Needs and Context)

1. Name of Institution: Gender: Male

[ ] Female [ ]

2. Position in Institution: Dean, School of Applied Science Member of Academic Board []

[ ] Industrial Liaison Officer [ ]

3. Qualification: Diploma [] Bachelors [] Masters [] Doctorate (PhD) [] Other specify.

Please tick $(\sqrt{ })$ the most appropriate option Response

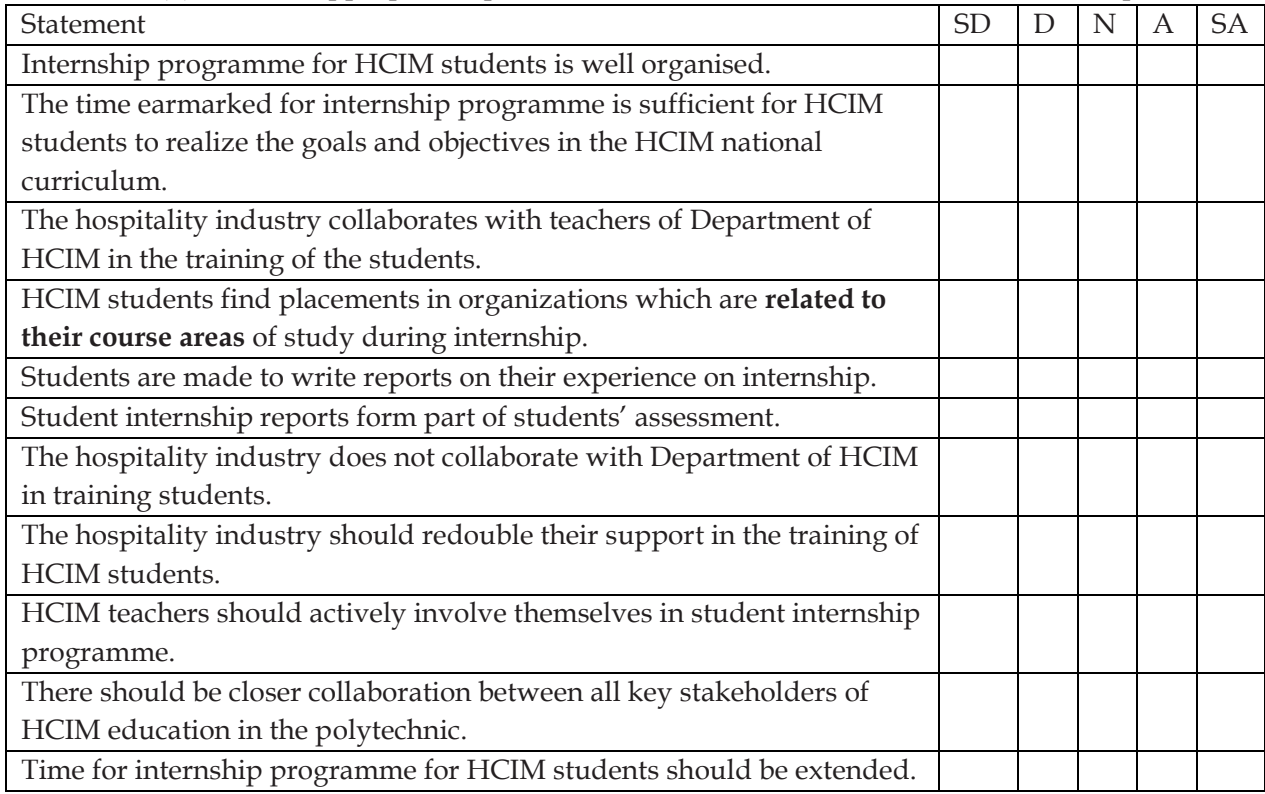

4. In your opinion, who are the key stakeholders of HCIM education?

5. Please list the individuals or bodies involved in the design and development of the national HCIM curriculum.

6. In what forms do they collaborate in ensuring that the intended attitudes, knowledge and skills in the national HCIM curriculum are real needs of the society, and achievable?

7. Please in your opinion, what could be done to improve upon the existing structure set up to design and develop national HCIM curriculum?

8. What specific functions do you want the key stakeholders of HCIM to play?

9. Please, what are your suggestions toward improving teaching and learning in the Department of HCIM (Generally)? 


\section{APPENDIX A3}

Student questionnaire (Needs and Context)

1. Name of Institution:

3. Name of Institution:

4. Year group: HND I [ ] HND II [ ] HND III [ ]

5. First placement for internship programme:

Name of organisation:.

Duration:

6. Second placement for internship programme:

Name of organisation:.....

Duration:

Please tick $(\sqrt{ })$ the most appropriate option Response

\begin{tabular}{|l|l|l|l|l|l|}
\hline Statement & SD & D & N & A & SA \\
\hline Internship programme for HCIM students is well implemented. & & & & & \\
\hline $\begin{array}{l}\text { The time earmarked for internship programme is sufficient for HCIM } \\
\text { students to realize the goals and objectives in the HCIM national } \\
\text { curriculum. }\end{array}$ & & & & & \\
\hline $\begin{array}{l}\text { The hospitality industry collaborates with teachers of Department of } \\
\text { HCIM in the training of the students. }\end{array}$ & & & & \\
\hline $\begin{array}{l}\text { HCIM students find placements in organizations which are related to } \\
\text { their course areas of study during internship. }\end{array}$ & & & & \\
\hline Students are made to write reports on their experience on internship. & & & & \\
\hline Student internship reports form part of students' assessment. & & & & \\
\hline $\begin{array}{l}\text { The hospitality industry does not collaborate with Department of HCIM } \\
\text { in training students. }\end{array}$ & & & & \\
\hline $\begin{array}{l}\text { The hospitality industry should redouble their support in the training of } \\
\text { HCIM students. }\end{array}$ & & & & \\
\hline $\begin{array}{l}\text { HCIM teachers should actively involve themselves in student internship } \\
\text { programme. }\end{array}$ & & & & \\
\hline $\begin{array}{l}\text { There should be closer collaboration between all key stakeholders of } \\
\text { HCIM education in the polytechnic. }\end{array}$ & & & & \\
\hline Time for internship programme for HCIM students should be extended. & & & & & \\
\hline
\end{tabular}

7. List at least three problems you encounter in teaching and learning in the Department of HCIM which adversely affect your performance.

8. List at least three problems you encounter during internship and training programme which adversely affect your performance.

9. In your opinion, who are the key stakeholders of HCIM education?

10. What specific functions do you want the key stakeholders of HCIM to play?

11. Please, what are your suggestions toward improving teaching and learning in the Department of HCIM? 


\section{APPENDIX A4}

Past student questionnaire (Needs and Context)

1. Name of Polytechnic attended:. 2. Gender: Male [ ] Female []

3. Year of completion:.. 4. Are you employed? No [ ] Yes [ ]

5. Name of employment:. 6. Type of employment:.

7. Position in employment:......

Please tick $(\sqrt{ })$ the most appropriate option Response

\begin{tabular}{|l|l|l|l|l|l|}
\hline Statement & SD & D & N & A & SA \\
\hline Internship programme for HCIM students is well implemented. & & & & & \\
\hline $\begin{array}{l}\text { The time earmarked for internship programme is sufficient for HCIM } \\
\text { students to realize the goals and objectives in the HCIM national } \\
\text { curriculum. }\end{array}$ & & & & & \\
\hline $\begin{array}{l}\text { The hospitality industry collaborates with teachers of Department of } \\
\text { HCIM in the training of the students. }\end{array}$ & & & & \\
\hline $\begin{array}{l}\text { HCIM students find placements in organizations which are related to } \\
\text { their course areas of study during internship. }\end{array}$ & & & & \\
\hline Students are made to write reports on their experience on internship. & & & & \\
\hline Student internship reports form part of students' assessment. & & & & \\
\hline $\begin{array}{l}\text { The hospitality industry does not collaborate with Department of HCIM } \\
\text { in training students. }\end{array}$ & & & & \\
\hline $\begin{array}{l}\text { Employers are generally satisfied with the job performance of HCIM } \\
\text { students. }\end{array}$ & & & & \\
\hline $\begin{array}{l}\text { There should be closer collaboration between all key stakeholders of } \\
\text { HCIM education in the polytechnic. }\end{array}$ & & & & \\
\hline Time for internship programme for HCIM students should be extended. & & & & & \\
\hline
\end{tabular}

8. Please specific other challenges that adversely affect teaching and learning in the Department of $\mathrm{HCIM}$, if any, that you encountered in the period of your training.

9. Please, what are your suggestions toward improving teaching and learning in the Department of HCIM? 


\section{APPENDIX A5 \\ Industry representative questionnaire (Needs and Context)}

1. Location of industry/Organisation:

2. Name of industry/organisation:.

3. Type of organisation/Industry:.

4. Status of respondents:.

Please tick $(\sqrt{ })$ the most appropriate option

Response

\begin{tabular}{|l|l|l|l|l|l|}
\hline Statement & SD & D & N & A & SA \\
\hline Internship programme for HCIM students is well implemented. & & & & & \\
\hline $\begin{array}{l}\text { The time earmarked for internship programme is sufficient for HCIM } \\
\text { students to realize the goals and objectives in the HCIM national } \\
\text { curriculum. }\end{array}$ & & & & \\
\hline $\begin{array}{l}\text { The hospitality industry collaborates with teachers of Department of } \\
\text { HCIM in the training of the students. }\end{array}$ & & & & \\
\hline $\begin{array}{l}\text { HCIM students find placements in organizations which are related to } \\
\text { their course areas of study during internship. }\end{array}$ & & & & \\
\hline Students are made to write reports on their experience on internship. & & & & \\
\hline $\begin{array}{l}\text { The hospitality industry does not collaborate with Department of HCIM } \\
\text { in training students. }\end{array}$ & & & & \\
\hline $\begin{array}{l}\text { Employers are generally satisfied with the job performance of HCIM } \\
\text { students. }\end{array}$ & & & & & \\
\hline $\begin{array}{l}\text { There should be closer collaboration between all key stakeholders of } \\
\text { HCIM education in the polytechnic. }\end{array}$ & & & & \\
\hline Time for internship programme for HCIM students should be extended. & & & & & \\
\hline
\end{tabular}

5. What is the role of hospitality industry regarding the realization of the national goals and objectives in HCIM curriculum in HCIM students?

6. In your opinion, who are the key stakeholders of HCIM education in the polytechnic?

7. What specific functions do you want the key stakeholders of HCIM to play?

8. Please, what are your suggestions toward improving teaching and learning in the Department of HCIM? 


\section{APPENDIX B 1}

Teacher questionnaire (1 ${ }^{\text {st }}$ design and implementation study)

\section{SECTION A: BACKGROUND INFORMATION}

Please tick $(\checkmark)$ in the appropriate box and provide answers where spaces are provided.

1. Name of Institution: Gender: Male [ ] Female [ ]

2. Course domain taught: Front Office Operation [ ] Accommodation Operation [] Food Production [] Food and Beverage [ ] Other (Please specify):.

3. Qualification: HND [] Diploma [] Bachelors [] Masters [] Other specify ....

4. For how long have you been teaching in the Polytechnic? ..years

5. Have you ever engaged in a curriculum activity? $\quad$ No [ ] Yes []

6. If yes to question 5 , please

When (year) Where (town/ city/ country)

Name of organizing body

7. What was your level of participation in the curriculum activity (what role did you play)?

8. Please describe the nature of the curriculum activity

9. What attitudes, knowledge and skills did you acquire during the curriculum activity?

10. In a teacher design team entrusted with the preparation of curriculum, what attitudes, knowledge and skills do you possess? 
Perceived initial competencies of teacher in collaborative curriculum design (CCD)

Please indicate to what extent you agree or disagree to each of the following statements.

\begin{tabular}{|c|c|c|c|c|c|}
\hline $\begin{array}{l}\text { Statement } \\
\text { Perceptions -1. Professional commitment }\end{array}$ & SD & $\mathrm{D}$ & $\mathrm{N}$ & A & SA \\
\hline When I work in a CCD, I do better quality work. & & & & & \\
\hline My work is better organized, when I am in the CCD. & & & & & \\
\hline $\begin{array}{l}\text { Our team has a growing understanding of how the curricular } \\
\text { material will impact on student internship. }\end{array}$ & & & & & \\
\hline $\begin{array}{l}\text { I know how to turn a work group into a smooth functioning } \\
\text { team. }\end{array}$ & & & & & \\
\hline $\begin{array}{l}\text { The content knowledge of the curricular material is accepted by } \\
\text { consensus. }\end{array}$ & & & & & \\
\hline $\begin{array}{l}\text { The skill of assessing students on internship programme can } \\
\text { improve. }\end{array}$ & & & & & \\
\hline Students' guidance before internship programme can improve. & & & & & \\
\hline Content of student industrial reports can improve. & & & & & \\
\hline Assessment of students' industrial reports can improve. & & & & & \\
\hline 2. Interdependence & & & & & \\
\hline When I work in a CCD, I end up doing most of the work. & & & & & \\
\hline The work takes longer to complete when I work with the CCD. & & & & & \\
\hline $\begin{array}{l}\text { My group members help explain things that I do not } \\
\text { understand. }\end{array}$ & & & & & \\
\hline I feel working in the CCD is a waste of time. & & & & & \\
\hline 3. Healthy interpersonal relationship & & & & & \\
\hline I feel comfortable involving teachers in team decisions. & & & & & \\
\hline $\begin{array}{l}\text { I know how to keep a conflict situation moving towards a } \\
\text { productive situation in the CCD. }\end{array}$ & & & & & \\
\hline I find it hard to express my thoughts, when I work in the CCD. & & & & & \\
\hline $\begin{array}{l}\text { My group members make me feel that I am not as smart as they } \\
\text { are. }\end{array}$ & & & & & \\
\hline 4. Mutual respect & & & & & \\
\hline I feel I am part of what is going on in the CCD. & & & & & \\
\hline $\begin{array}{l}\text { When I work in the CCD, there are opportunities to express your } \\
\text { opinions. }\end{array}$ & & & & & \\
\hline Teachers in the design team do not care about my feelings. & & & & & \\
\hline My group members do not respect my opinions. & & & & & \\
\hline 5. Participative decision making & & & & & \\
\hline $\begin{array}{l}\text { I know how to employ participative decision making techniques } \\
\text { in CCD. }\end{array}$ & & & & & \\
\hline When I work in the CCD, I am able to share my ideas. & & & & & \\
\hline $\begin{array}{l}\text { I know which situations are inappropriate for participative } \\
\text { decision making. }\end{array}$ & & & & & \\
\hline
\end{tabular}


APPENDIX B 2

Student (Questionnaire) [1 $1^{\text {st }} \& 2^{\text {nd }}$ design and implementation studies]

1. Year group: HND I [ ] HND II [ ]

2. Place of impending internship

Town/city:

Name of organization:

Self-Assessment of Competencies of Students - Food Production Operation

\begin{tabular}{|l|l|l|l|l|l|}
\hline Statement & SD & D & N & A & SA \\
\hline $\begin{array}{l}\text { I am able to cooperate with other persons in the hospitality } \\
\text { industry. }\end{array}$ & & & & \\
\hline I am familiar with the use of kitchen equipment and tools. & & & & & \\
\hline $\begin{array}{l}\text { I am able to identify the procedures to follow once an order has } \\
\text { been received. }\end{array}$ & & & & \\
\hline I am familiar with all methods of cooking. & & & & \\
\hline I am able to cook for number of guests as required. & & & & \\
\hline $\begin{array}{l}\text { I am able to prepare dishes using a variety of commodities and } \\
\text { cooking methods. }\end{array}$ & & & & \\
\hline I am able to use the various methods of preservation. & & & & \\
\hline I am able to prepare, cook and present Ghanaian ethnic dishes. & & & & & \\
\hline I am able to prepare, cook and present international ethnic dishes. & & & & & \\
\hline
\end{tabular}

Self-Assessment of Competencies of Students - Food and Beverage

\begin{tabular}{|l|l|l|l|l|l|}
\hline Statement & SD & D & N & A & SA \\
\hline I am able to wait on customers at the restaurant. & & & & & \\
\hline I acquire the skills to promote customer satisfaction. & & & & & \\
\hline I am able serve food and drink well in the restaurant. & & & & & \\
\hline I am able to lay tables for different functions at the restaurant. & & & & & \\
\hline I am able to resolve guests' complaints. & & & & & \\
\hline I am able to use the right equipment in restaurant service. & & & & \\
\hline I co-operate with and assist others in restaurant service. & & & & & \\
\hline $\begin{array}{l}\text { I design and produce promotional material, including point of sale } \\
\text { advertisements for special events. }\end{array}$ & & & & & \\
\hline I use, clean and maintain equipment in a safe professional manner. & & & & & \\
\hline
\end{tabular}


Self-Assessment of Competencies of Students - Front Office Operation

\begin{tabular}{|c|c|c|c|c|c|}
\hline \multirow{2}{*}{\multicolumn{6}{|c|}{$\begin{array}{l}\text { Statement } \\
\text { I am familiar with the scope of the lodging/hotel industry. }\end{array}$}} \\
\hline & & & & & \\
\hline $\begin{array}{l}\text { I identify the different types of accommodation facilities, grading } \\
\text { systems and tariff structures within the hospitality industry. }\end{array}$ & & & & & \\
\hline I am familiar with front office operations. & & & & & \\
\hline I identify types of reservations in hospitality industry. & & & & & \\
\hline I am able to identify the functions of the front office and its personnel. & & & & & \\
\hline I understand the grading system used in rating hotels in Ghana. & & & & & \\
\hline $\begin{array}{l}\text { I am able to identify different room types and abbreviations commonly } \\
\text { used. }\end{array}$ & & & & & \\
\hline I am familiar with the front office operations. & & & & & \\
\hline $\begin{array}{l}\text { Reservation records and forecasting are very important in front office } \\
\text { operations. }\end{array}$ & & & & & \\
\hline I am able to handle guest enquires. & & & & & \\
\hline I understand the accounting system at the front office. & & & & & \\
\hline I know the check-out procedures and settlement. & & & & & \\
\hline
\end{tabular}

Self-Assessment of Competencies of Students - Accommodation Operation

\begin{tabular}{|c|c|c|c|c|c|}
\hline Statement & SD & D & $\mathrm{N}$ & A & SA \\
\hline $\begin{array}{l}\text { I am familiar with the housekeeping department, its organisation and } \\
\text { its relationship with other departments. }\end{array}$ & & & & & \\
\hline I understand the use of various cleaning agents and equipment. & & & & & \\
\hline $\begin{array}{l}\text { I am familiar with different types of materials used throughout room } \\
\text { interiors. }\end{array}$ & & & & & \\
\hline I apply hotel and catering laws. & & & & & \\
\hline I clean materials using correct agent and equipment. & & & & & \\
\hline I clean and care for bathroom/toilet. & & & & & \\
\hline I care for and clean types of floors including carpets. & & & & & \\
\hline I care for and clean ceilings and wall coverings. & & & & & \\
\hline $\begin{array}{l}\text { I am able to prepare floral arrangements and designs to suit different } \\
\text { occasions }\end{array}$ & & & & & \\
\hline
\end{tabular}




\section{APPENDIX B 3}

Question-line or Question guide (Guide to Focus Group Discussion) - Students [1 ${ }^{\text {st }} \& 2^{\text {nd }}$ design and implementation studies]

1. What do you understand by the concept 'Internship Programme'?

2. Which group of students are supposed to go through internship programme?

3. What are the benefits of internship programme?

4. Have you had an experience of internship?

5. What did you gain out of internship programme?

6. For how long did you go on internship?

7. What was the attitude of industrial staff toward you?

8. Who were your supervisors during internship?

9. What is the nature of the report written during internship programme?

10. Which aspects of the four main areas of HCIM programme were you exposed to during internship?

11. What functions do you want the Liaison Unit to perform regarding student internship?

12. What challenges did you encounter during internship?

13. What suggestions will you consider for improvement in internship? 
APPENDIX B 4

Checklist (Monitoring of students on internship)

[1 $1^{\text {st }} \& 2^{\text {nd }}$ design and implementation studies]

A. Background information

1. Name of industry (organization):

2. Town/City of industry:

3. Visiting time:

4. Year group of student: HND I [ ]

5. Starting date:

HND II [ ]

6. Date of ending:

B. Observations at industry (interact with student and industry personnel)

\begin{tabular}{|l|l|l|}
\hline \multicolumn{1}{|c|}{ Activity } & \multicolumn{1}{|c|}{ How it is carried out } & Remarks \\
\hline Student assigned role & & \\
\hline Industry training & & \\
\hline Working environment & & \\
\hline Industry supervision & & \\
\hline $\begin{array}{l}\text { Other industry } \\
\text { support }\end{array}$ & & \\
\hline $\begin{array}{l}\text { Teacher supervision } \\
\text { Competencies } \\
\text { expected }\end{array}$ & & \\
\hline $\begin{array}{l}\text { Competencies } \\
\text { achieved }\end{array}$ & & \\
\hline $\begin{array}{l}\text { Assessment of } \\
\text { curriculum materials }\end{array}$ & & \\
\hline
\end{tabular}


APPENDIX B 5

Administrators in industry questionnaire $\left[1^{\text {st }} \& 2^{\text {nd }}\right.$ design and implementation studies]

SECTION A: BACKGROUND INFORMATION

Please tick $(\checkmark)$ in the appropriate box and provide answers where spaces are provided.

1. Location of industry:

2. Name of organisation:

3. Type of organisation:

4. Status of organization (rating):.....

5. Status of respondents: Head of Organisation [ ]

$$
\text { Supervisor [ ] Other (please specify): }
$$

B: MAIN DATA

PRACTICAL TRAINING IN INDUSTRY FOR HOTEL CATERING AND INSTITUTIONAL MANAGEMENT (HCIM) STUDENTS OF POLYTECHNICS

\begin{tabular}{|l|l|l|l|l|l|}
\hline Statement & SD & D & N & A & SA \\
\hline $\begin{array}{l}\text { 6. There is formal agreement between the polytechnic and } \\
\text { organisations in Ghana }\end{array}$ & & & & \\
\hline $\begin{array}{l}\text { 7. The polytechnic makes prior contacts with industrial } \\
\text { organisations before students are sent out for the internship. }\end{array}$ & & & & \\
\hline $\begin{array}{l}\text { 8. The polytechnic looks for organisations for students to } \\
\text { practise. }\end{array}$ & & & & \\
\hline $\begin{array}{l}\text { 9. Teachers from the polytechnic are actively involved in } \\
\text { student internship programme. }\end{array}$ & & & & \\
\hline $\begin{array}{l}\text { 10. There is enough teacher supervision of students during } \\
\text { internship. }\end{array}$ & & & & \\
\hline $\begin{array}{l}\text { 11. Students are made to write reports on their experience on } \\
\text { internship. }\end{array}$ & & & & \\
\hline $\begin{array}{l}\text { 12. During internship teachers go round to supervise students' } \\
\text { work in industry. }\end{array}$ & & & & \\
\hline $\begin{array}{l}\text { 13. There is proper supervision of students on internship by } \\
\text { supervisor in industry. }\end{array}$ & & & & \\
\hline $\begin{array}{l}\text { 14. Industry reports on the performance of HCIM students to } \\
\text { the polytechnic. }\end{array}$ & & & & \\
\hline $\begin{array}{l}\text { 15. Employers are generally satisfied with the job performance } \\
\text { of HCIM students from the polytechnic. }\end{array}$ & & & & \\
\hline
\end{tabular}

16. Please specify the departments of your organization where HCIM students serve (tick as many as apply):

Food Production (kitchen

[ ] Food and Beverage (restaurant) [ ]

Accommodation (housekeeping)

Others (please specify):.

[ ] Front Office Operation (reception) [ ] 
17. Please state specific training given to HCIM students during industrial attachment.

18. Please assess the general comportment (conduct or behaviour) of HCIM students on internship.

Very Bad [ ] Bad [ ] Good [ ] Very Good [ ] Excellent [ ]

19. To what extent has the curricular material impacted on the student industrial attachment?

20. Please, what are your suggestions for improving student internship programme for HCIM students? 
APPENDIX B 6

Student (Questionnaire) [1 $1^{\text {st }} \& 2^{\text {nd }}$ design and implementation studies]

1. Year group: HND I [ ] HND II [ ] 2. Gender: Male [ ]

3. Where did you have the first placement for Internship Programme?

a) Name of Organisation for first placement:

b) Town/city of organisation/enterprise:

c) Duration for Internship Programme (in months)

4. Where will you be having the next placement for industrial attachment programme?

a) Name of Organisation:

b) Town/city of organisation/enterprise for the next placement:

c) Duration for Internship Programme (months):.

Organization and implementation of internship

\begin{tabular}{|c|c|c|c|c|c|}
\hline Statement & SD & $\mathrm{D}$ & $\mathrm{N}$ & A & SA \\
\hline $\begin{array}{l}\text { 5. There is formal agreement between the polytechnic and organisations } \\
\text { in Ghana. }\end{array}$ & & & & & \\
\hline $\begin{array}{l}\text { 6. The polytechnic makes prior contacts with organisations before } \\
\text { students are sent out for internship. }\end{array}$ & & & & & \\
\hline 7. The polytechnic looks for organisations for students to practise. & & & & & \\
\hline $\begin{array}{l}\text { 8. Active participation of teachers in HCIM Department in internship } \\
\text { programme. }\end{array}$ & & & & & \\
\hline 9. Teachers supervise students' work during internship. & & & & & \\
\hline 10. There is enough teacher supervision of students during internship. & & & & & \\
\hline $\begin{array}{l}\text { 11. Students are made to write reports on their experience on } \\
\text { internship. }\end{array}$ & & & & & \\
\hline 12. Student internship reports form part of students' assessment. & & & & & \\
\hline $\begin{array}{l}\text { 13. There is proper supervision of students on internship by supervisor } \\
\text { in organisations. }\end{array}$ & & & & & \\
\hline $\begin{array}{l}\text { 14. Industry reports on the performance of HCIM students to the } \\
\text { polytechnic. }\end{array}$ & & & & & \\
\hline
\end{tabular}

15. Please specify the departments of the organization (hotel) where you serve (tick as many as apply):

Food Production (kitchen) [ ] Food and Beverage (restaurant) [ ]

Accommodation Department [ ] Front Office Operation (reception) []

Others (please specify): 
EVALUATION OF INDUSTRIAL ATTACHMENT PROGRAMME

Self-Assessment of Competencies of Students - Food Production Operation

\begin{tabular}{|l|l|l|l|l|l|}
\hline Statement & SD & D & N & A & SA \\
\hline $\begin{array}{l}\text { 16. I am able to cooperate with other persons in the hospitality } \\
\text { industry. }\end{array}$ & & & & & \\
\hline 17. I am familiar with the use of kitchen equipment and tools. & & & & & \\
\hline $\begin{array}{l}\text { 18. I am able to identify the procedures to follow once an order has } \\
\text { been received. }\end{array}$ & & & & \\
\hline 19. I am familiar with all methods of cooking. & & & & & \\
\hline 20. I am able to cook for number of guests as required. & & & & \\
\hline $\begin{array}{l}\text { 21. I am able to prepare dishes using a variety of commodities and } \\
\text { cooking methods. }\end{array}$ & & & & & \\
\hline 22. I am able to use the various methods of preservation. & & & & \\
\hline 23. I am able to prepare, cook and present Ghanaian ethnic dishes. & & & & & \\
\hline 24. I am able to prepare, cook and present international ethnic dishes. & & & & & \\
\hline
\end{tabular}

Self-Assessment of Competencies of Students - Food and Beverage

\begin{tabular}{|l|l|l|l|l|l|}
\hline Statement & SD & D & N & A & SA \\
\hline 25. I am able to wait on customers at the restaurant. & & & & & \\
\hline 26. I acquire the skills to promote customer satisfaction. & & & & & \\
\hline 27. I am able serve food and drink well in the restaurant. & & & & & \\
\hline 28. I am able to lay tables for different functions at the restaurant. & & & & & \\
\hline 29. I am able to resolve guests' complaints. & & & & & \\
\hline 30. I am able to use the right equipment in restaurant service. & & & & & \\
\hline 31. I co-operate with and assist others in restaurant service. & & & & & \\
\hline $\begin{array}{l}\text { 32. I design and produce promotional material, including point of } \\
\text { sale advertisements for special events. }\end{array}$ & & & & \\
\hline 33. I use, clean and maintain equipment in a safe professional manner. & & & & & \\
\hline
\end{tabular}

Self-Assessment of Competencies of Students - Front Office Operation

\begin{tabular}{|c|c|c|c|c|c|}
\hline Statement & SD & D & $\mathrm{N}$ & A & SA \\
\hline 34. I am familiar with the scope of the lodging/hotel industry. & & & & & \\
\hline $\begin{array}{l}\text { 35. I identify the different types of accommodation facilities, grading } \\
\text { systems and tariff structures within the hospitality industry. }\end{array}$ & & & & & \\
\hline 36. I am familiar with front office operations. & & & & & \\
\hline 37. I identify types of reservations in hospitality industry. & & & & & \\
\hline $\begin{array}{l}\text { 38. I am able to identify the functions of the front office and its } \\
\text { personnel. }\end{array}$ & & & & & \\
\hline 39. I understand the grading system used in rating hotels in Ghana. & & & & & \\
\hline $\begin{array}{l}\text { 40. I am able to identify different room types and abbreviations } \\
\text { commonly used. }\end{array}$ & & & & & \\
\hline 41. I am familiar with the front office operations. & & & & & \\
\hline $\begin{array}{l}\text { 42. Reservation records and forecasting are very important in front } \\
\text { office operations. }\end{array}$ & & & & & \\
\hline 43. I am able to handle guest enquires. & & & & & \\
\hline 44. I understand the accounting system at the front office. & & & & & \\
\hline 45. I know the check-out procedures and settlement. & & & & & \\
\hline
\end{tabular}


Self-Assessment of Competencies of Students - Accommodation Operation

\begin{tabular}{|c|c|c|c|c|c|}
\hline \multirow{2}{*}{$\begin{array}{l}\text { Statement } \\
\text { 46. I am familiar with the housekeeping department, its organisation } \\
\text { and its relationship with other departments. }\end{array}$} & SD & $\mathrm{D}$ & $\mathrm{N}$ & $\mathrm{A}$ & SA \\
\hline & & & & & \\
\hline 47. I understand the use of various cleaning agents and equipment. & & & & & \\
\hline $\begin{array}{l}\text { 48. I am familiar with different types of materials used throughout } \\
\text { room interiors. }\end{array}$ & & & & & \\
\hline 49. I apply hotel and catering laws. & & & & & \\
\hline 50. I clean materials using correct agent and equipment. & & & & & \\
\hline 51. I clean and care for bathroom/toilet. & & & & & \\
\hline 52. I care for and clean types of floors including carpets. & & & & & \\
\hline 53. I care for and clean ceilings and wall coverings. & & & & & \\
\hline $\begin{array}{l}\text { 54. I am able to prepare floral arrangements and designs to suit } \\
\text { different occasions }\end{array}$ & & & & & \\
\hline $\begin{array}{l}\text { 55. Employers are generally satisfied with the job performance of } \\
\text { HCIM students from the polytechnic. }\end{array}$ & & & & & \\
\hline
\end{tabular}

56. Please describe briefly what you gained during the recent industrial attachment.

Please select $(\checkmark)$ one of the options, in each case, regarding your industrial experiences for the first and second industrial attachment programme.

57. First industrial attachment (in terms of knowledge, skills in hospitality):
Very Bad [ ]
Bad [ ]
Good []
Very Good []
Excellent [ ]

58. Second industrial attachment (in terms of knowledge, skills in hospitality):
Very Bad [ ]
Bad []
Good [ ]
Very Good [ ]
Excellent []

Assessment of material by students

\begin{tabular}{|l|l|l|l|l|l|}
\hline Statement & SD & D & N & A & SA \\
\hline 59. The curricular material helps me during internship. & & & & & \\
\hline $\begin{array}{l}\text { 60. The curricular material helps me to write my industrial } \\
\text { report. }\end{array}$ & & & & & \\
\hline
\end{tabular}




\section{APPENDIX B 7}

Industrial Liaison Officer Interview, Tamale Polytechnic (1 ${ }^{\text {st }}$ design and implementation study)

1. For how long have you been industrial liaison officer?

2. What are your functions as industrial liaison officer?

3. What specific roles did you play in the recent student internship?

4. What role is expected of lecturers in student internship?

5. What role is expected of the polytechnic administration regarding student internship?

6. What role is expected of students during student internship?

7. What are your personal observations regarding the recent student internship?

8. What are some of the challenges you encounter as industrial liaison officer?

9. What can be done to help improve student internship?

10. Any other comment?

11. Do you get any external support from the community e. g. NGOs? 


\section{APPENDIX B 8}

Teacher questionnaire (1 ${ }^{\text {st }}$ design and implementation study)

\section{SECTION A: BACKGROUND INFORMATION}

Please tick $(\checkmark)$ in the appropriate box and provide answers where spaces are provided.

1. Name of Institution: ..................................... Gender: Male [ ] Female []

2. Course domain taught: Front Office Operation [ ] Accommodation Operation [ ] Food Production [ ] Food and Beverage [ ] Other (Please specify)......

Support for Design Teams

\begin{tabular}{|l|l|l|l|l|l|}
\hline Resources/support & SD & D & N & A & SA \\
\hline $\begin{array}{l}\text { 3. Teacher design teams have been allocated time to plan and monitor } \\
\text { their activities. }\end{array}$ & & & & \\
\hline $\begin{array}{l}\text { 4. Teacher design teams have been allocated space to carry out their } \\
\text { activities. }\end{array}$ & & & & \\
\hline 5. Polytechnic recognizes teacher design teams' activities. & & & & \\
\hline $\begin{array}{l}\text { 6. We use resources from the polytechnic institution to develop the } \\
\text { curriculum materials. }\end{array}$ & & & & \\
\hline
\end{tabular}

7. What kind of support is given by the polytechnic institution to the teachers in curriculum design teams?

Evaluation of training sessions for collaborative curriculum design in design teams

\begin{tabular}{|l|l|l|l|l|l|}
\hline Support & SD & D & N & A & SA \\
\hline 8. I benefit from the training sessions. & & & & & \\
\hline 9. The goal of the training sessions is clear. & & & & & \\
\hline 10. The content is worth studying. & & & & & \\
\hline 11. I understand the training sessions. & & & & & \\
\hline 12. I waste my time attending the training sessions. & & & & \\
\hline
\end{tabular}

13. What should have been done to improve training sessions (suggestions for improvement)? 
Organization and implementation of internship programme (level of participation)

\begin{tabular}{|c|c|c|c|c|c|}
\hline Statement & SD & $\mathrm{D}$ & $\mathrm{N}$ & A & SA \\
\hline $\begin{array}{l}\text { 14. There is formal agreement between the polytechnic and } \\
\text { Organisations in Ghana. }\end{array}$ & & & & & \\
\hline $\begin{array}{l}\text { 15. The polytechnic makes prior contacts with organisations before } \\
\text { students are sent out for the internship. }\end{array}$ & & & & & \\
\hline $\begin{array}{l}\text { 17. Active participation of teachers in HCIM Department in internship } \\
\text { programme. }\end{array}$ & & & & & \\
\hline 18. Teachers supervise students' work during internship. & & & & & \\
\hline 19. There is enough teacher supervision of students during internship. & & & & & \\
\hline 20. Students are made to write reports on their experience on internship. & & & & & \\
\hline 21. Student internship reports form part of students' assessment. & & & & & \\
\hline $\begin{array}{l}\text { 22. There is proper supervision of students on internship by supervisor } \\
\text { in organisation. }\end{array}$ & & & & & \\
\hline $\begin{array}{l}\text { 23. Industry reports on the performance of HCIM students to the } \\
\text { polytechnic. }\end{array}$ & & & & & \\
\hline
\end{tabular}

24. What specific role is played by the polytechnic during student internship?

25. What can be done by the polytechnic to improve student internship programme?

26. What specific work do you carry out during student internship?

27. What problems, if any, did you encounter during the immediate internship?

28. Please specify the assessment criteria used for students during internship.

29. How many credit hours are allocated to student internship programme?

Evaluation of student internship - institutional

\begin{tabular}{|c|c|c|c|c|c|}
\hline Statement & SD & $\mathrm{D}$ & $\mathrm{N}$ & A & SA \\
\hline $\begin{array}{l}\text { 30. There is an improvement in the polytechnic support for organi } \\
\text { student internship programme. }\end{array}$ & & & & & \\
\hline $\begin{array}{l}\text { 31. Activities of industrial liaison unit towards student internship } \\
\text { programme have improved. }\end{array}$ & & & & & \\
\hline 32. Internship letters to hospitality industry are received on time. & & & & & \\
\hline 33. Teacher supervision of students on internship has improved. & & & & & \\
\hline $\begin{array}{l}\text { 34. Hospitality industry supervision of students on internship has } \\
\text { improved. }\end{array}$ & & & & & \\
\hline
\end{tabular}


Please indicate to what extent you agree or disagree to each of the following statements.

\begin{tabular}{|c|c|c|c|c|c|}
\hline $\begin{array}{l}\text { Statement } \\
\text { Perceptions -1. Professional commitment }\end{array}$ & SD & $\mathrm{D}$ & $\mathrm{N}$ & A & SA \\
\hline 35. When I work in a team, I do better quality work. & & & & & \\
\hline 36. My work is better organized, when I am in the CCD in team & & & & & \\
\hline $\begin{array}{l}\text { 37. Our team has a growing understanding of how the curricul } \\
\text { material will impact on student internship. }\end{array}$ & & & & & \\
\hline $\begin{array}{l}\text { 38. I know how to turn a work group into a smooth functioning } \\
\text { team. }\end{array}$ & & & & & \\
\hline $\begin{array}{l}\text { 39. The content knowledge of the curricular material is accepte } \\
\text { by consensus. }\end{array}$ & & & & & \\
\hline $\begin{array}{l}\text { 40. The skill of assessing students on internship programme cal } \\
\text { improve. }\end{array}$ & & & & & \\
\hline $\begin{array}{l}\text { 41. Students' guidance before internship programme can } \\
\text { improve. }\end{array}$ & & & & & \\
\hline 42. Content of student industrial reports can improve. & & & & & \\
\hline 43. Assessment of students' industrial reports can improve. & & & & & \\
\hline 2. Interdependence & & & & & \\
\hline 44. When I work in a team, I end up doing most of the work. & & & & & \\
\hline $\begin{array}{l}\text { 45. The work takes longer to complete when I work with the } \\
\text { team. }\end{array}$ & & & & & \\
\hline $\begin{array}{l}\text { 46. My group members help explain things that I do not } \\
\text { understand. }\end{array}$ & & & & & \\
\hline 47. I feel working in the team is a waste of time. & & & & & \\
\hline 3. Healthy interpersonal relationship & & & & & \\
\hline 48. I feel comfortable involving teachers in team decisions. & & & & & \\
\hline $\begin{array}{l}\text { 49. I know how to keep a conflict situation moving towards a } \\
\text { productive situation in the team. }\end{array}$ & & & & & \\
\hline $\begin{array}{l}\text { 50. I find it hard to express my thoughts, when I work in the } \\
\text { team. }\end{array}$ & & & & & \\
\hline $\begin{array}{l}\text { 51. My group members make me feel that I am not as smart as } \\
\text { they are. }\end{array}$ & & & & & \\
\hline 4. Mutual respect & & & & & \\
\hline $\begin{array}{l}\text { 52. I feel I am part of what is going on in the CCD in design } \\
\text { team. }\end{array}$ & & & & & \\
\hline $\begin{array}{l}\text { 53. When I work in the CCD in design team, there are } \\
\text { opportunities to express your opinions. }\end{array}$ & & & & & \\
\hline 54. Teachers in the design team do not care about my feelings. & & & & & \\
\hline 55. My group members do not respect my opinions. & & & & & \\
\hline 5. Participative decision making & & & & & \\
\hline $\begin{array}{l}\text { 56. I know how to employ participative decision making } \\
\text { techniques in TDT. }\end{array}$ & & & & & \\
\hline $\begin{array}{l}\text { 57. When I work in the CCD in design team, I am able to share } \\
\text { my ideas. }\end{array}$ & & & & & \\
\hline $\begin{array}{l}\text { 58. I know which situations are inappropriate for participative } \\
\text { decision making. }\end{array}$ & & & & & \\
\hline
\end{tabular}


APPENDIX B 9 (1 st $^{\text {st }}$ esign and implementation study)

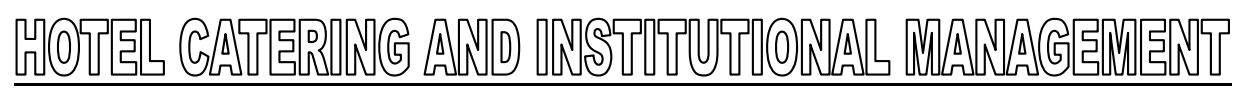

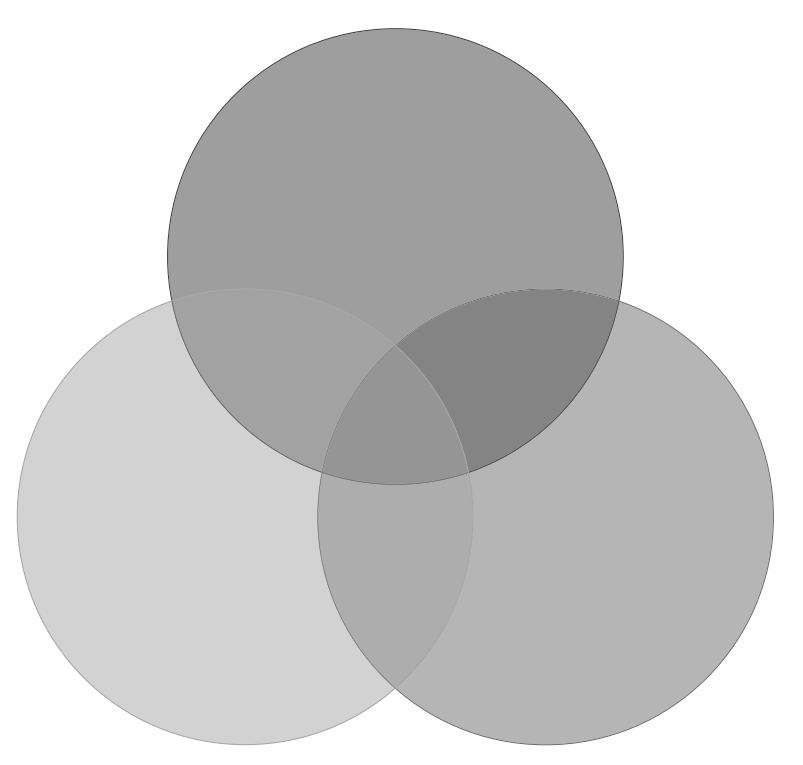

CURRICULARMATERIAL FOR STUDENTS ONINDUSTRIALATTACHMENT 


\section{RATIONALE}

The underlying principle for preparing this document is to ensure that the various stakeholders of Hotel, Catering and Institutional Management (HCIM) Programme are guided as to what to do when students are on industrial attachment. Stakeholders (students, teachers and industry representatives) are at liberty to make input into the document. It is hoped that this document will help industry to encourage job rotation for students on industrial attachment so as to better prepare students for the world of work.

\section{INDUSTRY EXPECTATION DURING ORIENTATION OF INTERNS}

1. Information on the organization

2. Procedures and policies of company

3. Working hours

4. Allowance (if any)

5. Public holidays

6. Benefits (if any)

7. Hygiene and safety policies

8. Facilities e.g. gymnasium, lavatory (restroom), recreational centre

9. Labour relations

10. Tasks and responsibilities

11. Introduction to staff

12. Job description (Document provided)

The mentor is requested to supply students with a manual that includes information such as, working hours, correct clothing, availability of transport, meal and lunch including or not included, overtime and allowance.

Working hours per week (42 - 45 hours per week) according to the needs of the institution (indicate by institution to industry)

Report file for review on monthly basis proof of training (Report Files / Log book)

Evaluation form must be signed by an authorized person and (mentor or employer); form should be authenticated by official stamp.

An interview at the end of training

Assessment

Assessor or lecturer should assess by checking the log book and daily activities recorded. 


\section{CURRICULAR MATERIAL FOR HCIM STUDENTS ON ATTACHMENT FOOD PRODUCTION}

\section{General Objective}

To train students to acquire skills, knowledge and attitudes that will help them become job creators (self reliant) and also to be able to manage or supervise effectively any hospitality industry.

\section{Specific Objectives}

Industry should provide students with in-depth practical skills on:

a. Mis-en-place for different types of meal preparation

b. Hygiene and safety procedures

c. Food preparations and cooking

\section{Content of Food Production Operation}

Mis-en-place

- Peeling and cleaning of vegetables

- Chopping and slicing of vegetables

- Greasing of baking equipment

- Blending of vegetables

- Measuring of ingredients using the appropriate measuring equipment or device

Identification and use of kitchen equipment (large, mechanical and small)

Methods of cooking

- Be familiar with various cooking methods (e.g. boiling, steaming, frying, baking etc)

- Be familiar with cold preparations: hors d'euvres, salad and salad dressings and their preparation and presentation.

- Be familiar with various stocks, sauces and soup preparation and presentation

- Be familiar with preparation and presentation of various pastries

- Observe hygiene and safety rules before, during and after meal preparation

Scullery (cleaning up working area after meal preparation)

\section{CURRICULAR MATERIAL FOR HCIM STUDENTS ON ATTACHMENT}

\section{FOOD AND BEVERAGE OPERATION (RESTAURANT SERVICE)}

\section{Specific Objectives}

Industry should provide students with in-depth practical skills on:

a. Food and beverage service sequence

b. Mis-en-place for different types of service

c. Hygiene and safety procedures 
Food and Beverage Operation Content

Mis-en-place

- Preparation for service

- Napkin folding

- Laying of table (e.g. á la cart and Table d'hôte covers)

- Polishing of glasses, cutlery etc

- Stocking of side boards and bars

Be familiar with the following basic technical skills:

- Carrying plates

- Using a service salver

- Carrying glasses

- Carrying clean cutlery and flatware

- Carrying coffee service

- Using a service plate

- Carrying trays etc.

Be familiar with the following interpersonal skills

- Addressing customers during service

- Receiving customers

- Taking orders/booking

Be familiar with the following:

- Taking customer food and beverage orders

- Service of food, alcoholic and non-alcoholic bar beverages

- Clearing of tableware during and after meal

The following applies to students on hospital attachment:

Students should study under the dietician to know various dietary needs for different types of patients.

Be familiar with the following:

- Type of menu e.g. full or normal diets, light diets, soft diets, therapeutic diets, and special diets.

- Menu planning

- Daily purchasing of food commodities

- Controlling of cost within the department

- Taking food orders from various wards

- Store keeping

- Stock taking

- Laundry

- Portion control 


\section{FRAMEWORK FOR ACCOMMODATION}

\section{GENERAL OBJECTIVES}

Identify the types of equipments, materials and how to use them.

Be familiar with cleaning agents, and how to use them.

Be familiar with beds, beddings and bed marking.

\section{SPECIFIC OBJECTIVES}

A. Students should apply the rules and regulations regarding cleaning of rooms.

B. Students should be able to carry out the types of cleaning:

i) daily cleaning,

ii) weekly cleaning,

iii) periodic cleaning (every 2-4 months) and

iv) annual cleaning.

C. Students should apply the appropriate procedures for making a bed and turning down a bed.

D. Students should apply appropriate technology for waste disposal (procedures and processes).

E. Students should be familiar with pest control measures

F. Students should interpret the colour wheel and discuss the choice of colour schemes.

G. Be familiar with living room procedures, shorting

H. List the basic tools for flower arrangement.

\section{ACCOMMODATION CONTENT}

\section{EQUIPMENT}

- Identify manual equipment e.g. brushes, mops, cloths, containers.

- Mechanical equipment - Vacuum or suction cleaners, scrubbing polishing machines, etc.

- Care of the equipment

- Should be able to use the above-mentioned equipment

\section{CLEANING AGENTS}

- Should be able to know how to use the various cleaning agents to remove dirt.

- These include water, detergents, toilet cleaners, bleaches, polishes

- Should also be able to make a choice of cleaning agents by taking into consideration the point in choosing cleaning agents.

\section{CLEANING}

- Should be able to identify the difference between dirt and dust and how to clean them.

- Removal of stains

\section{BED MAKING}

- Should know how to strip soiled linen

- Turn down a bed

- Make a bed

- Know the various linen used in bed making

- Placement of pillows on bed 


\section{PESTS AND WASTE DISPOSAL}

- Known how hygienically to dispose off waste materials to prevent pest and rodents in the department e.g. dust bins, liquid waste from sinks, baths, kitchen wastes

\section{INTERIOR DECORATION}

- Should observe the choice of colours and designs in the establishment.

- Should also observe the decorations, designs of furniture, etc.

- Identify the various floorings, curtains, lighting, fittings and shades

- Also observe and practise floral arrangement.

\section{LINEN ROOM}

- Known linen room procedures-: Security, exchanges of line, dispatch, inspection, storage of linen, stocktaking, repairs, laundry

- Control of linen

- Record keeping

\section{MAINTENANCE}

- Repair faults e.g. dripping taps, WC

- Cisterns, faulty electrical plugs etc.

\section{FRAMEWORK FOR FRONT OFFICE}

Attributes of the Front Office Personnel

1. Maintain good eye contact but must be careful not to turn eye contact into a stare.

2. Smile when talking to guest.

3. Stand up straight and avoid leaning or slouching.

4. Maintain a clean, neat and tidy personal appearance at all times. By paying attention to what you wear.

5. Speak clearly and loudly using a pleasant tone.

6. Must be very punctual.

7. Finger nails should not be coated with bright nail polish; make-ups should be moderate.

8. Must communicate effectively with guest.

9. Ready to attend to guest problems.

10. Must have in-depth knowledge about the establishment; immediate environs and the various tourist attractions and other places of interest.

11. Avoid the use of strong scented perfumes.

\section{General Objectives}

Students should be familiar with Front Office Operations.

Students should demonstrate practical skills in Front Office procedures.

Specific Objectives

The guest cycle

Front Office records

Front Office equipment

Should know how to write reports 
Front Office Content

1. How to welcome guest (checklist)

2. How to receive reservation, overbooking, no-show

(a) Guest with reservation

(b) Walk-in-guest

3. How to handle overbooking

4. How to handle no-show

5. Registration process - how to record a guest's personal details

6. How to assign a room to a guest

7. Checking the methods of payment

8. How to issue a room key and escort a guest 


\section{APPENDIX C 1}

\section{Teacher questionnaire (2 ${ }^{\text {nd }}$ design and implementation study)}

\section{SECTION A: BACKGROUND INFORMATION}

Please tick $(\checkmark)$ in the appropriate box and provide answers where spaces are provided.

1. Name of Institution: Gender: Male [ ] Female [ ]

2. Course domain taught: Front Office Operation [ ] Accommodation Operation

Food Production [ ] Food and Beverage [ ] Other (Please specify):

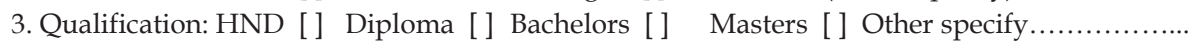

4. For how long have you been teaching in the Polytechnic?

5. Have you ever engaged in a curriculum activity? No [ ] Yes [ ]

6 . If yes to question 5 , please

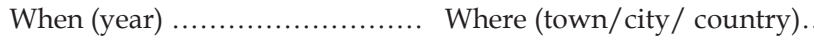

Name of organizing body.....

7. What was your level of participation in the curriculum activity (what role did you play)?

8. Please describe the nature of the curriculum activity

9. What attitudes, knowledge and skills did you acquire during the curriculum activity?

10. In a teacher design team entrusted with the preparation of curriculum, what attitudes, knowledge and skills do you possess?

Perceived initial competencies of teacher in collaborative curriculum design (CCD)

Please indicate to what extent you agree or disagree to each of the following statements.

\begin{tabular}{|c|c|c|c|c|c|}
\hline $\begin{array}{l}\text { Statement } \\
\text { Perceptions -1. Professional commitment }\end{array}$ & SD & $\mathrm{D}$ & $\mathrm{N}$ & A & SA \\
\hline When I work in a team, I do better quality work. & & & & & \\
\hline My work is better organized, when I am in the team. & & & & & \\
\hline $\begin{array}{l}\text { Our team has a growing understanding of how the curricular } \\
\text { material will impact on student internship. }\end{array}$ & & & & & \\
\hline $\begin{array}{l}\text { I know how to turn a work group into a smooth functioning } \\
\text { team. }\end{array}$ & & & & & \\
\hline $\begin{array}{l}\text { The content knowledge of the curricular material is accepted by } \\
\text { consensus. }\end{array}$ & & & & & \\
\hline $\begin{array}{l}\text { The skill of assessing students on internship programme can } \\
\text { improve. }\end{array}$ & & & & & \\
\hline Students' guidance before internship programme can improve. & & & & & \\
\hline Content of student industrial reports can improve. & & & & & \\
\hline Assessment of students' industrial reports can improve. & & & & & \\
\hline
\end{tabular}




\section{APPENDIX C 2}

Interview guide for industry representatives ( $2^{\text {nd }}$ design and implementation study)

(Perceptions of the context and needs assessment, challenges, contribution/suggestions)

\section{A. Biographic Data}

1. Name:

2. Gender: Male [ ] Female []

3. Position in organization:.....

4. For how long have you been working in the hospitality industry (hotel)?

\section{B. Questions}

1. What are your views on results on the context and needs assessment carried out in 2008 ?

2. What is your experience on students who come on internship?

3. Are you satisfied with their job performance during internship?

4. What challenges does the organization face regarding internship?

5. What are your suggestions for improving internship in the hospitality industry? 


\section{APPENDIX C 3 \\ Interview schedule for the industrial liaison officer ( $2^{\text {nd }}$ design and implementation study)}

(Perceptions on the needs \& context analysis, contribution to curricular material and polytechnic support of teacher design teams) - 1

\section{A. Biographic Data}

1. Name:

2. Position in the polytechnic:

3. For how long have you been occupying this position?

\section{B. Questions}

1. What is the role of the industrial liaison unit?

2. How is internship organised in the polytechnic?

3. What do you make out of the results of the needs and context analysis of 2008 ?

4. What is your assessment of the training sessions for lecturers in the Department of HCIM?

5. What contribution do you make toward the design of the curricular material for student internship? (In terms of ideas)

6. What support can be given to the teacher design teams preparing the curricular material of student internship?

7. What are your challenges regarding organisation of student internship?

8. What are your expectations in the upcoming student internship?

9. Do you have any suggestions for improving teacher design teams' activities? 


\section{APPENDIX C 4}

Researcher' logbook (2nd design and implementation study)

Ensuring quality of curriculum materials

Date:

School/Department:

Identification of needs/challenges facing student internship:

Students:

Teachers:

Industry representatives:

Suggestions from stakeholders to improve student internship:

Students:

Teachers:

Industry representatives:

Assessment of curriculum materials:

Students:

Teachers:

Industry representatives: 


\section{APPENDIX C 5}

Industry-based supervisor assessment ( $2^{\text {nd }}$ design and implementation study)

$1=$ Weak $2=$ Below average $3=$ Average $4=$ Good $5=$ Outstanding

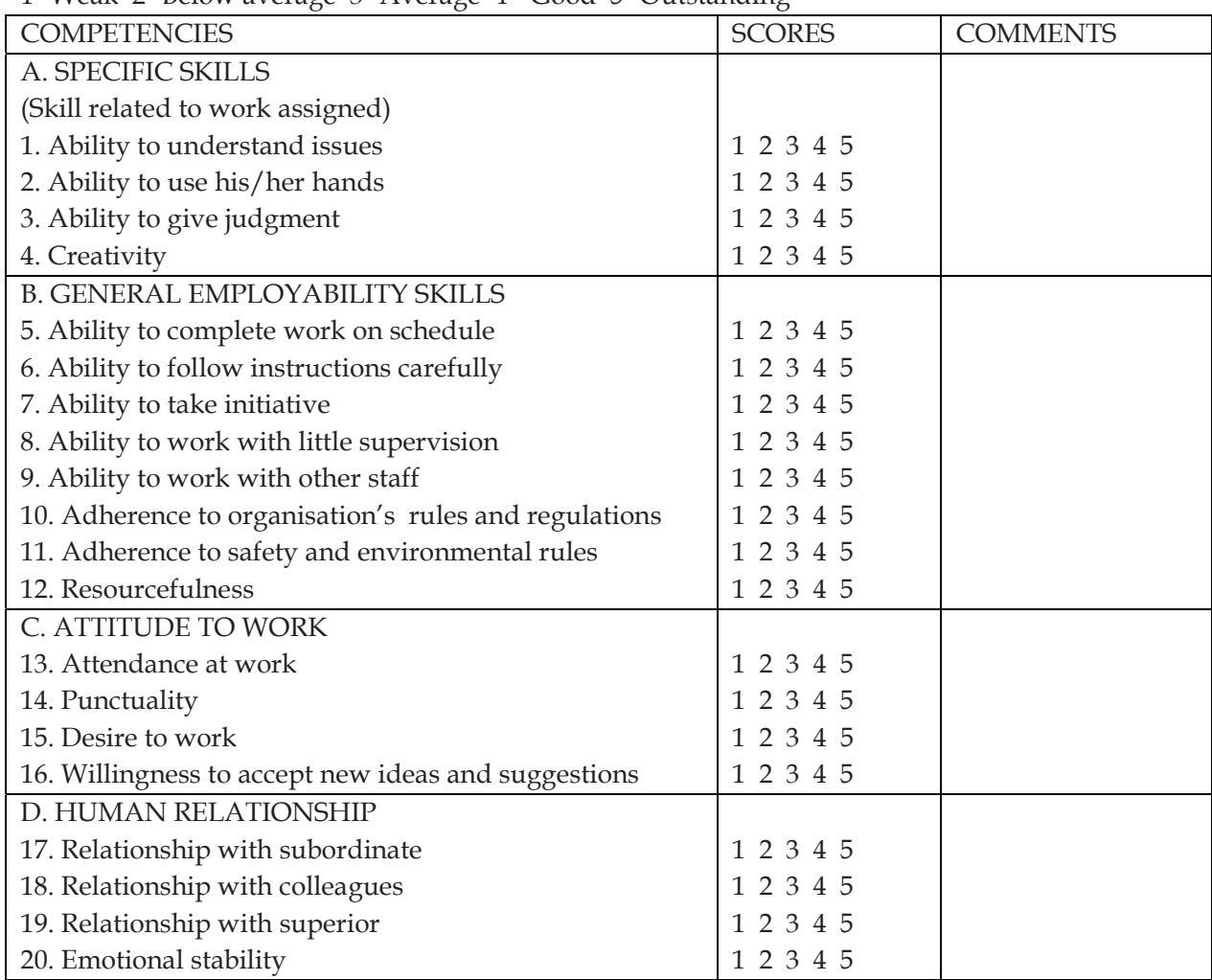

21. General remarks:.

22. Suggestion(s): 


\section{APPENDIX C 6 \\ Interview schedule for the industrial liaison officer, Takoradi Polytechnic [2nd design and implementation study]}

(Perceptions of the curricular material, contribution to internship, challenges and suggestions for improvement) - 2

\section{A. Biographic Data}

1. Name:

2. Position in the polytechnic:

3. For how long have you been occupying this position?

\section{B. Questions}

1. What are your views on the curricular material for student internship?

2. What specific role did your outfit play during the 2010 internship?

3. What was the role of lecturers in the 2010 internship?

4. What is the role of students in internship programme?

5. What contribution was made toward the 2010 internship by the polytechnic (industrial liaison unit)?

6. What challenges did your outfit face during the 2010 student internship?

7. Do you have any suggestions for improving student internship programme? 


\section{APPENDIX C 7}

Semi-structured interview guide for teachers ( $2^{\text {nd }}$ design and implementation study)

A. Biographic Data

1. Name...

2. Gender: Male [] Female []

3. Highest academic qualification:.

4. What is your subject area?

5. Years of teaching in the polytechnic:.

6. Have you ever engaged in any curriculum activity? No [ ] Yes [ ]

7. Where did you have such an experience?

8. What did you learn from the curriculum activity?

\section{B. Questions}

1. What characteristics (behaviours) did you exhibit during the preparation of the curriculum materials?

2. What did you benefit out of the collaborative curriculum design in teacher team?

3. What is your assessment of the curricular material prepared?

4. What role did you play in the recent (2010) student internship?

5. What is your assessment of the polytechnic support of the design teams?

6. What are the attitudes of students towards student internship?

7. To what extent did the curriculum materials influence the training of students during internship?

8. Do you have any suggestions that can help improve upon student internship? 


\section{APPENDIX C 8 \\ Teacher questionnaire (2nd design and implementation study)}

\section{SECTION A: BACKGROUND INFORMATION}

Please tick $(\checkmark)$ in the appropriate box and provide answers where spaces are provided.

1. Name of Institution Gender: Male [ ] Female []

2. Course domain taught: Front Office Operation [ ] Accommodation Operation

Food Production

[ ] Food and Beverage [ ]

Other (Please specify):.....

Support for CCD in Design Teams

\begin{tabular}{|c|c|c|c|c|c|}
\hline Resources/support & SD & $\mathrm{D}$ & $\mathrm{N}$ & $\mathrm{A}$ & SA \\
\hline $\begin{array}{l}\text { 3. Teacher design teams have been allocated time to plan and monitor } \\
\text { their activities. }\end{array}$ & & & & & \\
\hline $\begin{array}{l}\text { 4. Teacher design teams have been allocated space to carry out their } \\
\text { activities. }\end{array}$ & & & & & \\
\hline 5. Polytechnic recognizes teacher design teams' activities. & & & & & \\
\hline $\begin{array}{l}\text { 6. We use resources from the polytechnic institution to develop the } \\
\text { curriculum materials. }\end{array}$ & & & & & \\
\hline
\end{tabular}

7. What kind of support is given by the polytechnic institution to the teachers in curriculum design teams?

Organization and implementation of internship programme (level of participation)

\begin{tabular}{|c|c|c|c|c|c|}
\hline \multirow{2}{*}{\multicolumn{6}{|c|}{$\begin{array}{l}\text { Statement } \\
\text { 8. There is formal agreement between the polytechnic and } \\
\text { Organisations in Ghana. }\end{array}$}} \\
\hline & & & & & \\
\hline \multicolumn{6}{|l|}{$\begin{array}{l}\text { 9. The polytechnic makes prior contacts with organisations before } \\
\text { students are sent out for the internship. }\end{array}$} \\
\hline \multicolumn{6}{|l|}{$\begin{array}{l}\text { 10. Active participation of teachers in HCIM Department in internship } \\
\text { programme. }\end{array}$} \\
\hline \multicolumn{6}{|l|}{ 11. Teachers supervise students' work during internship. } \\
\hline \multicolumn{6}{|l|}{ 12. There is enough teacher supervision of students during internship. } \\
\hline \multicolumn{6}{|l|}{ 13. Students are made to write reports on their experience on internship. } \\
\hline \multicolumn{6}{|l|}{ 14. Student internship reports form part of students' assessment. } \\
\hline \multicolumn{6}{|l|}{$\begin{array}{l}\text { 15. There is proper supervision of students on internship by supervisor } \\
\text { in organisation. }\end{array}$} \\
\hline $\begin{array}{l}\text { 16. Industry reports on the performance of HCIM students to the } \\
\text { polytechnic. }\end{array}$ & & & & & \\
\hline
\end{tabular}

17. What specific role is played by the polytechnic during student internship? 
18. What specific work do you carry out during student internship?

19. Please specify the assessment criteria used for students during internship.

Evaluation of student internship - institutional

\begin{tabular}{|c|c|c|c|c|c|}
\hline Statement & SD & D & $\mathrm{N}$ & $\mathrm{A}$ & SA \\
\hline \multicolumn{6}{|l|}{$\begin{array}{l}\text { 20. There is an improvement in the polytechnic support for organizing } \\
\text { student internship programme. }\end{array}$} \\
\hline \multicolumn{6}{|l|}{$\begin{array}{l}\text { 21. Activities of industrial liaison unit towards student internship } \\
\text { programme have improved. }\end{array}$} \\
\hline \multicolumn{6}{|l|}{ 22. Internship letters to hospitality industry are received on time. } \\
\hline \multicolumn{6}{|l|}{ 23. Teacher supervision of students on internship has improved. } \\
\hline $\begin{array}{l}\text { 24. Hospitality industry supervision of students on internship has } \\
\text { improved. }\end{array}$ & & & & & \\
\hline
\end{tabular}

Please indicate to what extent you agree or disagree to each of the following statements.

\begin{tabular}{|c|c|c|c|c|c|}
\hline $\begin{array}{l}\text { Statement } \\
\text { Perceptions -Professional commitment }\end{array}$ & SD & $\mathrm{D}$ & $\mathrm{N}$ & A & SA \\
\hline 25. When I work in CCD team, I do better quality work. & & & & & \\
\hline 26. My work is better organized, when I am in the CCD. & & & & & \\
\hline $\begin{array}{l}\text { 27. Our team has a growing understanding of how the curricular } \\
\text { material will impact on student internship. }\end{array}$ & & & & & \\
\hline $\begin{array}{l}\text { 28. I know how to turn a work group into a smooth functioning } \\
\text { team. }\end{array}$ & & & & & \\
\hline $\begin{array}{l}\text { 29. The content knowledge of the curricular material is accepted by } \\
\text { consensus. }\end{array}$ & & & & & \\
\hline $\begin{array}{l}\text { 30. The skill of assessing students on internship programme can } \\
\text { improve. }\end{array}$ & & & & & \\
\hline 31. Students' guidance before internship programme can improve. & & & & & \\
\hline
\end{tabular}


APPENDIX C 9 (2nd design and implementation study)

\section{DEPARTMENT OF HOSPITALITY MANAGEMENT}

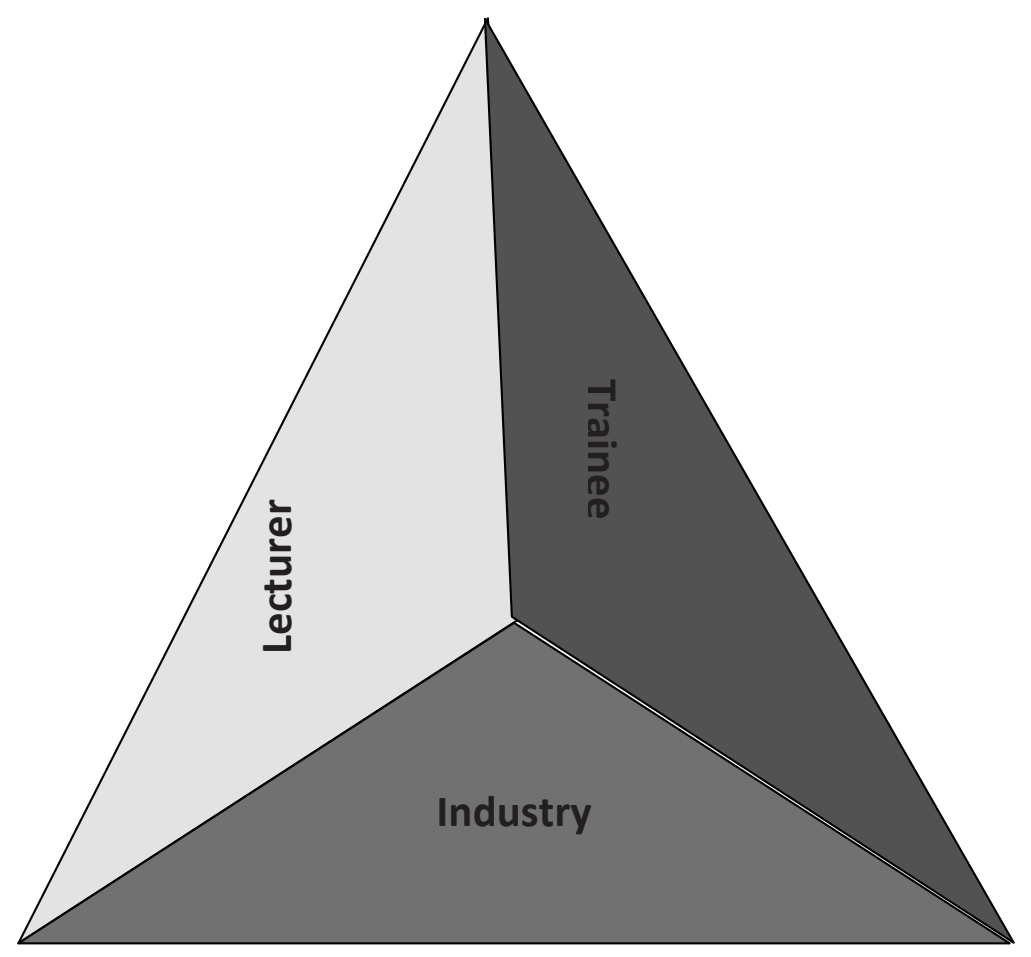

CURRICULAR MATERIAL FOR INTERNSHIP 2010 


\section{RATIONALE}

The underlying principle for preparing this document is to ensure that the various stakeholders of Hotel, Catering and Institutional Management (HCIM) Programme are guided as to what to do when students are on industrial attachment. Stakeholders (students, teachers and industry representatives) are at liberty to make input into the document. It is hoped that this document will help industry to encourage job rotation for students on industrial attachment so as to better prepare students for the world of work.

\section{INDUSTRY EXPECTATION DURING ORIENTATION OF INTERNS}

When students go on industrial attachment, management should be able to introduce students at the various departments to acquaint themselves with what is done at every department and the correct usage of the tools and equipment used at the various sections.

It is expected that whenever students are around, they should try as much as possible to let students know whatever industry does (in terms of its operations). Students should not be perceived as threat to industry personnel.

1. Information on the organization

2. Procedures and policies of company

3. Working hours: prior notice should be given to students when they are going to stay longer than their normal closing time and transport services should be provided.

a. Allowance (if any)

b. Public holidays

c. Benefits (if any)

4. Hygiene policies (e.g. kitchen)

5. Safety policies (any emergency)

6. Labour policies for hotels

7. Job description and responsibilities

8. Students should be given tags with inscription as trainee.

9. Form A (in the training log book) should be completed by industry-based supervisor after the attachment programme.

\section{Assessment}

- Assessor or lecturer should assess by checking the log book and daily activities recorded.

- Assessment should be done by direct supervisor of the trainee.

\section{EXPECTATIONS FROM INTERNS}

- Students should submit to authority in the industry in line with the code of ethics of the establishment so as to learn from it.

- Students should observe personal hygiene such as tying of hair, wearing the appropriate outfit. Students should work under supervision.

- Assumption of duty form must be submitted to the Industrial Liaison Office within 7 days after assumption of attachment.

- Training Log Book should be kept by students throughout the attachment period.

- A comprehensive industrial attachment report to be submitted by students 2 weeks after attachment programme. 


\section{Curricular Material for Food Production}

Students should (be)

1. briefed on health hazard (HACCP)

2. taken through orientation to understand the organisation of the various units in the kitchen and what is done in each of the units; such as cold kitchen, pastry section, hot kitchen etc. if any.

3. make use of tools and equipment such as knives, measuring tools etc.

4. conversant with measurement and control system

5. taught how to use and adopt standard recipes i.e., industry standards in preparing meals (standard procedures).

6. taught the various methods of cooking foods; as well as presentation of food prepared e.g. garnishing and decoration of foods etc.

7. taught how to use convenience foods in meal preparation.

8. conversant with how hotel plans its menus or menu types, menu bank

9. rotated throughout the various units in the kitchen to get first hand experience.

10. taken through purchasing and store keeping procedures, requisition etc.

11. Emphasise the different ways of sanitizing the place i.e. the kitchen

12. Allow students to try their hands on actual food production.

Curricular Material for Food and Beverage (Restaurant service)

Students should be given orientation about the Food and Beverage Operation in the establishment.

Students should (be)

1. taught and practise mis-en-place for different types of service e.g. laying of table, changing a table cloth, folding napkins, polishing of glasses, cutlery, stocking side boards etc.

2. observe hygiene and safety procedures e.g. checking for chipped crockery before using to serve.

3. familiar with interpersonal skills:

- addressing customers during service

- receiving customers

- taking orders/booking and present bills (sequence of service)

- how to handle food from the kitchen to the guest/customer etc.

- briefed how to deal with customer complaints.

4. guided the correct usage and handling of equipment and tools (crockery).

5. taught how to practise all styles/types of service at the restaurant - plate service, silver service, buffet service, family service etc.

6. practise how to clean spillages and crumb down before guests.

7. practise room service - knocking of doors, carrying trays etc.

8. taught how to present, open and serve wine.

9. familiar with different glasses for wine service.

10. conversant with bar operations - opening stock, pre-operation and post operation.

11. familiar with the cellar bar in the hotel.

12. taught bar control e.g. drinks etc.

- Supply- stock taking inventories

- Storage- (returned) stock taking inventories

13. conversant with the service of alcoholic and non-alcoholic drinks e.g. how to serve beer etc.

14. familiar with the mixing of cocktail drinks organised in that hotel.

15. involved in the techniques of function organisation e.g. wedding reception, buffet lunch etc.

16. involve them in the techniques of function organisation 
- $\quad$ wedding reception, birthday party, send off party etc

- decoration for the various functions

- the use of checklist before and after functions

- outsourcing, ODC (outdoor catering), alfresco, banqueting procedures

\section{Curricular Material for Front Office Operation}

Students should find out the ownership of the hotel (classification by ownership):

- Franchise, chain, private, partnership etc.

Find out:

- Size - small, medium and large and star rating, grade

- Target market, e.g. tourists etc.

- Markets levels of service

- How automation is done: switch board, key card, normal keys/key board

- Kitchen - (sous vid)

Students should know the organisation structure of that hotel:

- Organisation structure of the front office

- Duties of the front office personnel and the use of the hotel brochure.

- Attributes of the front office person.

- The relationship existing between the front office and other departments

Students should find out if the hotel has won any award.

Students should know the room types, facilities, tariffs and abbreviations e.g.

- Twin bed - TB, Double bed - DB, Do not Disturb - DND, Out of Order - OOO/OOS etc.

Students should find out the front office design of that hotel:

- $\quad$ i.e. equipment - visa card validity detectors

- computer applications and systems

Students should know the types and sources of reservations.

- Guest cycle: registration process, check in, check out procedures etc.

Students should know the tools available to check for reservation, confirmation and maintenance.

Students should know how

- forecasting is done in that hotel,

- overbooking is handled

- chance guest and chance trade are handled

Students should be taught to handle guests:

- enquiries

- complaints

- property

- lost and found articles

- right of lien

Students should find out which methods of payment that hotel uses, visa card, cash etc.

Students should find out the communication requirement for that particular hotel:

- inter-intra departmental

- guest relations

Students should be taught how to handle emergencies e.g. fire outbreaks, unconscious guest etc.

Students should know the:

- accounting systems in that hotel

- tracking of transactions

- internal control - night audit 
Students should find out the billing systems of that hotel:

- manual

- computerised

Students should find out losses that occur in the hotel and how they are controlled.

Students should know the:

$\mathrm{B}^{\prime} \mathrm{TECH}$

- sources of the hotel's business

- advantages and disadvantages of their sources e.g. airlines, tourists, businessmen etc.

- handling of tour and group booking via travel agents etc.

- extent tourism and travel contribute to that hotel.

- how does the hotel do yield management?

- What is the composition of the yield management team?

- How does the team handle cash flow of the hotel?

Students should find out the room rating of that hotel and how it is calculated.

How does the hotel maximise room occupancy - Revenue forecasting?

How does the hotel review its budget and keep its target consistent?

How is the hotel connected to ECOWAS harmonized standard of classification

How does the hotel monitor performance for performance appraisal?

Students should be conversant with automation and technologies in that establishment.

Students should be exposed to suggestions for improvement of performance.

Students should be shown examples of daily analysis of that hotel.

Students should find out the front office systems and application that hotel uses.

Students should find out the security procedures of the hotel like the key control and management of guest lost properties.

\section{Curricular Material for Accommodation Operation HND ONE}

Students should (be)

1. briefed on the overview of the housekeeping department.

2. introduced to the types of the cleaning agents and cleaning equipment used by the hotel.

3. introduced to the different fabrics that the hotel uses for its interior decoration, e.g. draperies, curtains and bed linen.

4. familiarise themselves with the different floor surfaces, finishes and coverings in the hotel.

5. identify the different ceilings and wall coverings in that hotel.

6. taken through the routine work and duty roster in that hotel. That is, what is done in the morning, afternoon and evening. They should also be taught how to make beds as well as turning down a bed.

7. introduced to pelmets, valances, swags, different types of cushions and loose covers and blinds, and given the chance to clean them.

8. introduced to the different types and sizes of beds in that hotel e.g. king size, queen size, double bed, twin bed etc.

9. introduced to the different surfaces in that hotel and how to care for them; e.g. louver blades, decorative flower vases, ceramic, wooden chairs, metallic tables etc. 


\section{HND TWO}

Students should be

1. taught how to stock the cart room and the room attendant's cart.

2. introduced to the different types of cleaning that is done daily, weekly and periodically.

3. taught how to enter the guest room, how to dust surfaces, how to clean the basin, toilets, bath tube, wash basin and bidet.

4. taught how to clean public places:

Lobbies

Corridors

Public restrooms

Swimming pool areas

Gymnasia

Banquet rooms

Dining rooms

Meeting rooms

Sales offices

Employee area and administration

Students should be taught:

- Task and duties of linen room staff

- The layout of the linen room, stock and storage of linen in that establishment

- The flow of linen through OPL (on-premises-laundry) machines and equipment - their uses and operations

Students should be taught dry cleaning process in the laundry:

- Chemicals and machines used as well as fabrics that can be dry cleaned

- Stain removing procedure and agents used

Students should look out for various types of:

- Floral arrangement

- Lighting systems

Industrial Attachment for Bachelor of Technology in Accommodation (B. Tech.)

Students should be taught basic things for some time and be allowed to learn managerial aspect for the rest of their stay.

\section{Students should be}

1. given the chance to practise what was taught in HND I and II in the various departments for two weeks

2. taught the key areas in management: planning, organising, directing and controlling (supervision).

3. taken through the setting, monitoring and reviewing of standard.

4. taken through how inspections are carried out, faults are identified and reported for repair and maintenance.

5. taught how the hotel goes about security procedures like key control and management of guest properties.

6. taught how appraisal is done.

7. taught how to keep records and reports in the hotel.

8. taught managing inventories:

- Linen, uniforms etc. 
- Equipment/machines

- Cleaning materials

- Guest supplies

9. taught how to control expenses:

- Cash flow

- Budget process

- Contract versus in-house cleaning (OPL) 


\section{APPENDIX D 1}

Sustainability of curriculum materials (Teacher questionnaire)

[Sustainability study]

\section{SECTION A: BACKGROUND INFORMATION}

Please tick $(\checkmark)$ in the appropriate box and provide answers where spaces are provided.

1. Gender: Male [ ] Female []

2. Qualification:

HND [] Diploma [] Bachelor's Degree [] Master's Degree [] Other (please specify):......

3. For how long have you been teaching in the Polytechnic? years

SECTION B

Reasons for engaging in CCD as reported by teachers

\begin{tabular}{|c|c|c|c|c|c|}
\hline Working in teams & SD & D & $\mathrm{N}$ & A & SA \\
\hline 4. Delight in active involvement with other teachers & & & & & \\
\hline 5. I prefer design of curriculum materials with other teachers. & & & & & \\
\hline $\begin{array}{l}\text { 6. Cooperation with other teachers in designing curriculum materials to } \\
\text { improve internship }\end{array}$ & & & & & \\
\hline 7. Learning from other teachers when designing curriculum materials & & & & & \\
\hline 8. Continuation of teacher collaboration of designing curriculum materia & & & & & \\
\hline Quality curriculum materials & & & & & \\
\hline 9. Improved curriculum materials for internship through CDD & & & & & \\
\hline $\begin{array}{l}\text { 10. Curricula prepared by teachers can guarantee successful } \\
\text { implementation }\end{array}$ & & & & & \\
\hline 11. Encouragement of ownership of curriculum materials for internship & & & & & \\
\hline
\end{tabular}

Influence of curriculum materials on student internship

\begin{tabular}{|c|c|c|c|c|c|}
\hline Statement & SD & $\mathrm{D}$ & $\mathrm{N}$ & A & SA \\
\hline 12. Teacher supervision of students on internship has improved. & & & & & \\
\hline 13. Teacher involvement in student internship has improved. & & & & & \\
\hline $\begin{array}{l}\text { 14. Hospitality industry supervision of students on internship has } \\
\text { improved. }\end{array}$ & & & & & \\
\hline $\begin{array}{l}\text { 15. Student competencies have improved ever since the curriculum } \\
\text { material was used by students. }\end{array}$ & & & & & \\
\hline
\end{tabular}

Addressing internship challenges through curriculum materials

\begin{tabular}{|c|c|c|c|c|c|}
\hline Statement & SD & $\mathrm{D}$ & $\mathrm{N}$ & A & SA \\
\hline \multicolumn{6}{|l|}{ 16. Students on internship should be treated with respect. } \\
\hline \multicolumn{6}{|l|}{ 17. Meaningful work to be assigned to students during internship. } \\
\hline \multicolumn{6}{|c|}{$\begin{array}{l}\text { 18. Opportunity to serve in all the departments in the industry during } \\
\text { internship. }\end{array}$} \\
\hline \multicolumn{6}{|c|}{ 19. Industry workers cooperate and support students during internship. } \\
\hline \multicolumn{6}{|c|}{ 20. Industry to ensure proper supervision of students during internship. } \\
\hline 21. HCIM teachers' active involvement in student internship. & & & & & \\
\hline
\end{tabular}


Opinions of teachers towards CCD in design teams

\begin{tabular}{|c|c|c|c|c|c|}
\hline Benefit & SD & $\mathrm{D}$ & $\mathrm{N}$ & A & SA \\
\hline 22. I will consider CCD in team as an option in curriculum design. & & & & & \\
\hline 23. I do not mind to spend time in CCD sessions because of its benefits. & & & & & \\
\hline $\begin{array}{l}\text { 24. Design team can help me to collaborate with other teachers in realisi } \\
\text { curriculum improvement. }\end{array}$ & & & & & \\
\hline 25. Design team can help improve my content knowledge. & & & & & \\
\hline 26. Design teams can help me to solve problem in my subject area. & & & & & \\
\hline 27. Design team can help me learn new ideas about student internship. & & & & & \\
\hline 28. Design teams can help me to design improved curricular material. & & & & & \\
\hline
\end{tabular}




\section{APPENDIX D 2 \\ Teacher and management representative interview schedule on sustainability of curriculum materials and collaborative curriculum design (CCD) in design teams}

1. Name:

\section{B. Questions}

\section{RQ 1}

1. Do you still engage in curriculum design in design teams?

2. Do you consider the design of curriculum as part of the teachers' work and why?

3. How do you think involvement in CCD in design team can enhance curriculum material for student internship?

4. Do you still see collaborative curriculum design in design teams as relevant and why?

\section{RQ 2}

5. Are the curriculum materials designed for student internship being used by students?

6. Please give reasons for your response to question 5 ?

7. How have the curriculum materials influenced student internship?

8. In which ways do you think the curriculum materials influenced student competencies during and after the 2010 student internship?

9. What activities do you engage in through design teams regarding student internship?

\section{RQ 3}

10. What changes have taken place in the area of student internship practices so far since your involvement in design team?

11. What role did you play in the recent (2010) student internship?

12. How have the implementation challenges of student internship been resolved in the curriculum materials?

RQ 4

13. Would you consider CCD in design team as an option to any educational reform in the polytechnic (Department of HCIM)?

14. Please give reasons for your response to question 13 ? 
15. What is your overall perception towards sustenance of CCD in design teams for improvement in curriculum in the polytechnic?

16. What can be the support from management to sustain CCD in design teams in the polytechnic? 17. What is the motivating factor(s) relating to the sustenance of CCD for improved curriculum? 


\section{APPENDIX D 3}

Focus group discussion on the 2010 student internship

1. How will you describe the polytechnic's link with industry (organisations) regarding internship?

2. How was the industrial liaison unit involved in the 2010 student internship?

3. In which ways did teachers participate in the 2010 student internship?

4. In which ways did industry workers participate in the 2010 student internship?

5. What were the attitudes of industrial workers towards interns during the 2010 internship?

6. Were you kept in one department of the organisation during the 2010 student internship and how will you assess the work assigned?

7. How will you describe your experience at the 2010 internship?

8. What problems or challenges did you face during the 2010 student internship?

9. How useful was the curriculum material for the 2010 student internship? 


\section{APPENDIX D 4}

Student questionnaire on use and sustainability of curriculum materials

Please tick $(\checkmark)$ in the appropriate box and provide answers where spaces are provided.

1. Institution: Takoradi Polytechnic [ ] Tamale Polytechnic []

2. Year group: HND II [ ] HND III [ ]

3. Gender: Male [ ] Female [ ]

4. Did you take part in the 2010 internship programme?
No
Yes
5. Where did you do 2010 Internship programme?

a) Name of Organisation:

b) Town/city of organisation/enterprise

c) Duration for internship (in months)

6. In what ways did the curriculum material help you during the 2010 internship?

7. Please assess the usefulness of the curriculum material used for the 2010 internship.

8. Do you want to use the curriculum material for future internship?
No
Yes

9. Please give reason(s) for your answer to question 8 .

Influence of curriculum materials on student internship

\begin{tabular}{|l|l|l|l|l|l|}
\hline Statement & SD & D & N & A & SA \\
\hline 10. Teacher supervision of students on internship has improved. & & & & & \\
\hline 11. Teacher involvement in student internship has improved. & & & & & \\
\hline 12. Hospitality industry supervision of students has improved. & & & & & \\
\hline $\begin{array}{l}\text { 13. Student competencies have ever since the curriculum materials } \\
\text { were used have improved. }\end{array}$ & & & & & \\
\hline
\end{tabular}

Addressing industrial attachment challenges through curriculum material

\begin{tabular}{|l|l|l|l|l|l|}
\hline Statement & SD & D & N & A & SA \\
\hline 14. Students on industrial attachment should be treated with respect. & & & & & \\
\hline 15. Meaningful work to be assigned to students during internship. & & & & & \\
\hline $\begin{array}{l}\text { 16. Students should be given opportunity to serve in all the } \\
\text { departments in the hospitality industry during internship. }\end{array}$ & & & & & \\
\hline $\begin{array}{l}\text { 17. Industry workers cooperate and support students during } \\
\text { internship. }\end{array}$ & & & & & \\
\hline $\begin{array}{l}\text { 18. Industry to ensure proper supervision of students during } \\
\text { internship. }\end{array}$ & & & & \\
\hline \begin{tabular}{l} 
19. HCIM teachers' active involvement in student internship. \\
\hline
\end{tabular} & & & & & \\
\hline
\end{tabular}

20. Please specify the departments of the organization (hotel/hospital) where you serve (tick as many as apply): Food Production (kitchen) [ ] Accommodation (Housekeeping) Food and Beverage Department (restaurant) [ ] Front Office (reception)

Others (please specify): 


\section{APPENDIX D 5}

Hotel personnel interview on use and adoption of curriculum materials

\section{Bio-data}

1. Name of hotel:

2. Position in hotel (organisation):

\section{Section B}

1. Is the curriculum materials designed for student internship being used by students?

No $\square \quad$ Yes

2. Please give reasons for your response to question 1 ?

3. Would you advise the use of the curriculum materials for future student internship? No Yes

4. Please give reasons for your response to question 3?

5. How have the curriculum materials influenced student industrial attachment?

6. In which ways do you think the curriculum materials influenced student competencies during and after the 2010 student internship?

7. What role did you play in the recent (2010) student internship?

8. How have the implementation challenges of student internship been resolved in the curriculum materials? 